\title{
DIFUSÃO E CONSTRUÇÃO DO DESIGN NO BRASIL: O PAPEL DO MASP
}

MILENE SOARES CARA 


\section{DIFUSÃO E CONSTRUÇÃO DO DESIGN NO BRASIL: O PAPEL DO MASP}

MILENE SOARES CARA

Tese apresentada à Faculdade de Arquitetura e Urbanismo da Universidade de São Paulo para obtenção do título de Doutor em Arquitetura e Urbanismo.

Área de Concentraç̃o: HistóRIA E Fundamentos DA ARquitetura e Do URbanismo

Orientador: Prof. Dr. Luciano Migliaccio São Paulo, 2013 
Autorizo a reprodução e divulgação total ou parcial deste trabalho, por qualquer meio convencional ou eletrônico, para fins de estudo e pesquisa, desde que citada a fonte.

E-mail: milene.cara@uol.com.br

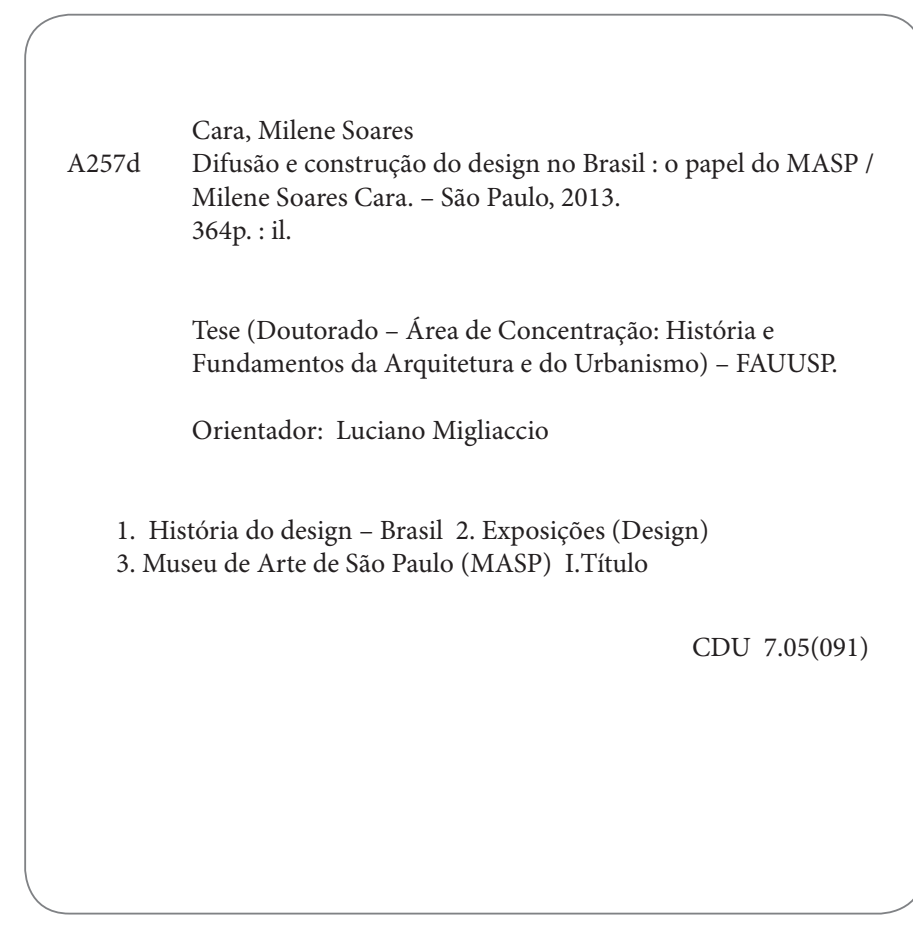

"A beleza aqui é como se a gente a bebesse,em copo,taça, longos, preciosos goles servida por Deus. É de pensar que também há um direito à beleza, que dar beleza a quem tem fo me de beleza é também um dever cristão."

João Guimarães Rosa - In: Grande Sertão: Veredas

Revisão: RoberTA BARADEL

Projeto gráfico e diagramação: EUnice Pontes 


\section{AgRADECIMENTOS}

Ao assumir o desafio de adentrar em um território ainda não desvendado, as muitas exposições realizadas pelo Museu de Arte de São Paulo (MASP) ao longo de aproximadamente quarenta e dois anos para elaborar este texto, quero agradecer àqueles que permitiram que este desafio e essa descoberta fossem bem sucedidos. Assim quero aqui expressar meus agradecimentos.

A memória e ao trabalho pioneiro de Pietro Maria Bardi e Lin Bo Bardi, pelo belíssimo legado e colaboração ao desenvolvimento dos mais variados campos da cultura neste País.

Às incansáveis e heroicas Paula Warchavchik Melardi, Eunice Pontes e Roberta Baradel, cujo apoio foi extraordinário ao longo do desenvolvimento desta pesquisa e, sobretudo, fundamental para o resultado final desta tese. Bravíssimas!

À Ivani Di Grazia Costa, Romeu De Loreto, Barbara Blanco Bernardes e Maíra Carvalho de Moraes; todos da Biblioteca e Centro de Documentação do MASP, pela infinita paciência e colaboração no levantamento das fontes primárias reunidas neste texto. E também às equipes das Bibliotecas do Museu de Arte Moderna de São Paulo (MAM SP), Museu de Arte Contemporânea da Universidade de São Paulo (MAC USP), Instituto Tomie Ohtake Museu da Casa Brasileira.

Ao professor e orientador Luciano Migliaccio e aos professore Chico Homem de Melo e Agnaldo Farias por todos os conselhos recebidos ao longo do desenvolvimento desta tarefa.

A Fundação de Amparo à Pesquisa do Estado de São Paulo (FAPESP) pelos recursos disponibilizados à esta pesquisa.

À minha família, por todo o carinho, cumplicidade, paciência e companheirismo dispensados ao longo de toda a vida e aos caríssimos amigos, pelos melhores momentos vividos. 


\section{RESU M O}

A tese Difusão e Construção do Design no Brasil: 0 papel do MASP foi construída sobre as bases lançadas pela pesquisadora em sua dissertação de mestrado Do D esenho Industrial ao Design - Uma Bibliografia Crítica para a Disciplina. Como a pesquisa anterior, de caráter antológico, o presente texto contém um amplo levantamento das atividades expositivas dedicadas à discussão do design realizadas no Museu de Arte de São Paulo (MASP) entre os anos 1947 e 1989, anos da gestão de Pietro Maria Bardi. Vistas enquanto conjunto, essas atividades oferecem um panorama gera das diversas questões propostas pelo Museu e sua contribuição para o debate da disciplina durante o período de consolidação do design no Brasil.

Se, por um lado, as duas pesquisas têm objetivo semelhante - a reunião de fontes importantes sobre o debate do design no País - por outro, diferem no modo de organização. Em lugar de uma divisão cronológica, adotou-se aqui a divisão temática para a apresentação das exposições realizadas pelo Museu e, como resultado, são apresentados sete ensaios precedidos por uma breve introdução contextual. Essa escolha se dá na medida em que muitos dos temas são recorrentes ao longo de toda a atividade de Pietro Maria Bardi como conservador-chefe do Museu, ao lado de Lina Bo Bardi.

Assim, tais ensaios, longe de limitarem-se à apresentação das exposições, têm como objetivo enunciar os principais temas propostos pelo Museu entre as décadas de 1950 e 1980 e contextualizá-los dentro do panorama da historiografia do design brasileiro. Ao anexo desta pesquisa, caberá o pape de apresentar brevemente a totalidade das exposições, bem como seus objetivos e as fontes localizadas no Centro de Documentação do Museu; tornando-se instrumento para futuras pesquisas àqueles interessados na análise e crítica da produção cultural para o design no Brasil. 
Deste amplo panorama, o destaque e análise dos principais temas recorrentes no discurso das exposições constitui uma metodologia original para a consolidação da historiografia da disciplina, ao demonstrar a importância do discurso das exposiçoes como reflexo relevante do pensamento deumaépoca.Eéjustamente a análise deste discurso realizada ao longo dos ensaios propostos, que permitirá enriquecimento do panorama da área por meio do resgate de uma visão original do Museu para o design, ao contrário de grande parte das reflexões presentes no debate da disciplina durante a segunda metade do século XX, cuja bandeira foi a construção de fronteiras claras a outros campos do conhecimento e, particularmente, à arte, como forma de afirmação.

Nestes termos, o Museu, desde sua fundação, ao adotar uma visão ampliada do campo da arte - arte como consequência do meio - compreenderá, sem distinções, o design também como manifestação artística. E por esta afirmação, o design é elemento importante da cultura como um todo, condição necessária par configuração do ambiente cotidiano e reflexo da multifacetad complexidade, desejos e atitudes de uma sociedade. Considerada esta posição, é possível afirmar que o MASP anteciparia, desde a sua fundação e ao longo de suas atividades, uma visão não só contemporânea do design, mas avessa a discursos restritivos, na qual design é resposta às exigências da modernidade, que, por sua vez, estão condicionadas às relativas noções de espaço e tempo, determinantes para a complexidade da disciplina.

Esta leitura proporcionará, portanto, uma contribuição valiosa um balanço do importante papel do Museu para a difusão construção do design no Brasil e oferecerá, assim, uma base oportuna à teoria e prática do design na atualidade.

\section{A BSTRACT}

The thesis Diffusion and Construction of Design in Brazll: the RO LE OF MASP was built on the fo undations laid by the researcher in her Masters dissertation From InDUSTRIAL DESIGN TO DESIGN - A CRITICal Biblography for the Discipline. As the previous research, of an anthological character, the present text contains a comprehensive survey of the exhibiting activities dedicated to the discussion of design held at the São Paulo Museum of Art (MASP) between the years 1947 and 1989, under the management of Pietro Maria Bardi. Viewed as a whole, these activities provide an overview of the various issues proposed by the Museum and its contribution to the debate of the discipline during the consolidation period of design in Brazil.

If, on the one hand, the two researches have similar goals the gathering of major sources of debate about design in the country - on the other, they differ in the mode of organization. Instead of a chronological division, we have adopted here, the thematic division for the presentation of exhibits held by the Museum, and, as a result, seven essays are presented preceded by a brief contextual introduction. This choice was made by a brief contextual introduction. This choice was made Pietro Maria Bardi as chief conservator of the museum, to gether with Lina Bo Bardi.

So these essays, far from being confined to a presentation of exhibits, aim to outline the main themes proposed by the museum between the 1950s and 1980s, and contextualize them within the panorama of the historiography of Brazilian design. The attachment in this research plays the role of briefly presenting all of the exhibitions, as well as their goals and the sources located in the Documentation C enter of the Museum becoming a tool for those interested in further research an

From this broad panorama, highlighting and analyzing the main recurringthemes in the discourse of the exhibits constitutes an original methodology for consolidating the historiography of the discipline, by demonstrating the importance of the discourse as a relevant reflection of the thought of an epoch. 
design, unlike most of the reflections present in the debate of the discipline during the second half of the twentieth century, whose motto was to build clear boundaries towards other fields of knowledge, and particularly towards art, as way of assertion.

Accordingly, the Museum, since its foundation, by adopting a broader view of the field of art - art as consequence of the social sphere - has included, without distinction, design also as artistic manifestation.And by this statement, design has been an important element of culture as a whole, a necessary condition for setting the daily environment and reflecting the multifaceted complexity, desires and attitudes of a society. Considering this position, it is possible to state that MASP has anticipated since its founding and over its activities, not only a contemporary view of design, but also averse to restrictive speeches, in which design is a response to the demands of modernity, which, in turn, are conditioned to the relative notions of space and time determinants for the complexity of the discipline.

This reading will provide, therefore, a valuable contribution, an overview of the important role the Museum has played towards the diffusion and construction of design in Brazil, and will offer, thus, a timely basis for the theory and practice of design today.

\section{SUMÁRIO}

15 InTRODUÇÃO

31 capítulo 1 - Artes industriais

57 Capítulo 2 - Exposições Didáticas II - O GRáaico

77 CAPítulo 3 - Exposições Didáticas III - A MOdA

103 CAPítulo 4 - O PAPEL do MASP na DIFUSÃO DO DISCURSO MOdeRnista (1950-1989)

119 Capítulo 5 - 0 PAPEL do MASP na difusão do discurso MOdERNISTA (1950-1989)

151 CAPítulo 6 - O MASP, AS EXPOSIÇÕ ES DEDICADAS AO DESIGN GRÁFICO BRASILEIRO E UMA NOVA CONFIGURAÇÃO ESTÉTICA

169 Capítulo 7 - O MASP, os Bardi E O LEGado a DOCUMENTAÇÃO DO DESIGN E DA ARTE POPULAR BRASILEIRA

193 CONCLUSÃO

199 BIBLIOGRAFIA

205 ANEXOS 


\section{INTRO DUÇÃO}

A tese Difusão e Construção do Design no Brasil:o papel do MASP foi construída sobre as bases lançadas pela pesquisadora em sua dissertação de mestrado e livro publicado Do D ESENHO In DUSTRIA ao Design - Uma Bibliografia Crítica para a Disciplina. E, para melhor compreender o objeto deste texto, são necessárias algumas linhas a respeito da pesquisa na qual esta se apoia.

Do Desenho Industrial ao Design - Uma Bibliografia Critica PARA A DISCIPLINA teve como objetivo inicial a constituição de uma bibliografia crítica sobre o design, elaborada a partir de uma abordagem histórica apoiada em três aspectos fundamentais: a crítica e a imprensa especializadas; as instituições de ensino e as exposições ou a criação de estruturas expositivas. Destes aspectos, a pesquisa de mestrado escolheu privilegiar a análise da produção crítica publicada, pois não havia como abordar, em tempo hábil, a significativa quantidade de material encontrado para a conclusão das investigações.

E para constituir um repertório de informações sobre disciplina elegeu-se o recorte temporal limitado entre os ano 1950 e 1970, período no qual o ensino do design é oficializado graças à criação de escolas superiores, e também um importante momento para o Brasil: a superação vertiginosa de uma estrutura predominantemente agrária para um modelo de economia baseado na produção industrial, com todas as suas consequências e modelo de planejamento para a nação que passam das mãos de um poder democrático para um regime militar extremamente desigual e opressor. São nestas circunstâncias que a disciplina pouco a pouco vai configurando-se na condição nacional.

E foi neste território movediço e pouco explorado que se construiu,por meio da leitura analítica da produção escrita produzida durante as três décadas, a compreensão do que se entedia por desenho industrial e o que passamos a compreender por design 
nos dias de hoje. Se esta pesquisa cumpriu o papel a que se propôs, também deixou lacunas. Um de seus aspectos fundamentais, as exposições, fora excluído da análise em virtude do feliz encontro com uma vasta produção textual, privilegiada. Porém, desde a sua conclusão, a oportunidade de refazer a trajetória para difusão e construção do design por meio do debate proposto pela exposições revelava-se um estimulante desafio àqueles que têm um pallino ${ }^{1}$ à cabeça.

E é este pallino orientado pela curiosidade acerca do discurso presente nas exposições dedicadas ao design que determinará o objeto desta pesquisa. A tese, ao destinar-se a ampliação do discurso da disciplina por meio do estudo das exposições, pretendeu apresentar as principais questões críticas abordadas por esta produção na difusão e construção do campo.

Inicialmente, ao privilegiarem-se as exposições como elemento central para a construção de uma análise crítica, elegeu-se, na incerteza do porvir, a totalidade das exposições realizadas na principais instituições museológicas paulistas e de outros estado durante a segunda metade do século XX. Tal orientação revelou-se um grande equívoco. A tarefa de reconhecimento dos território iniciou-se simultaneamente nas instituições paulistanas: Museu de Arte de São Paulo (MASP), Museu de Arte Moderna de São Paulo (MAM-SP), Museu de Arte Contemporânea da Universidade de São Paulo (MAC-USP), Museu da Casa Brasileira (MCB) e Instituto Tomie Ohtake. Entre a totalidade de eventos realizado por cada uma delas, foram identificadas as exposições dedicadas ao tema do design ou àquelas não diretamente relacionadas ao campo mas que permitiam o estabelecimento de relações com a disciplina. Porém, e aqui é que se explica o equívoco ou talvez, a feliz surpresa: a quantidade de exposições identificadas foi admirável. E se o vasto volume de eventos tornou mais urgente a necessidade do encontro com o legado proporcionado por estes, também fez da tarefa um trabalho hercúleo e, dadas as premissas estabelecidas para uma pesquisa desta natureza, inviável.
Naturalmente, as estratégias foram reconfiguradas na perspectiva de encontrar-se o equilíbrio entre o factível e o sonhado. E busca deste equilíbrio definirá escolhas e, dentre essas escolhas, elegeu-se o extraordinário legado proporcionado pelo MASP por meio de suas atividades expositivas. Foram as sucessivas e constantes idas à Biblioteca e Centro de Documentação do Museu que revelaram mais de 100 exposições propostas pela instituição ao longo de 42 anos, sobretudo entre os anos de 1947 e 1989, em que Pietro Maria Bardi foi o diretor-conservador ou conservadorchefe, posição na qual exercia o papel de mentor intelectual do museu, não somente responsável pelo acervo, mas também pela exposições apresentadas e pela política cultural da instituição.

As mais de 100 exposições identificadas, relacionadas direta ou indiretamente à discussão do design, evidenciaram não somente o interesse em relação ao tema, bem como a profunda contribuição ao campo no País por meio de proposições e debates manifestados por exposições, conferências, desfiles e atividades didáticas realizada pela instituição ao longo da segunda metade do século XX. Vale destacar que cada uma dessas atividades trouxe ainda consigo uma quantidade considerável de documentos, textos, fotografias, catálogos e fortuna crítica arquivadas na Biblioteca e Centro de Documentação do Museu.

Se a criação do Instituto de Arte Contemporânea (IAC), pelo MASP em 1951 foi um acontecimento de grande significado para o campo do design ${ }^{2}$ nos anos 1950, sobre o qual a literatura do campo tem dedicado com forte entusiasmo inúmeras pesquisas; é fundamental reconhecer que a contribuição do Museu, fundado por Assis Chateaubriand e pelo professor Pietro Maria Bardi, ao design foi muito além da breve experiência de três anos, período no qual o Instituto funcionou. Desde sua fundação e durante os mais de quarenta anos em que Bardi esteve em sua direção, ao lado da arquiteta Lina Bo Bardi, o Museu colaborou de forma singular e inédita, sobretudo por meio das inúmeras exposições dedicadas ao tema, para a construção e consolidação do campo no Brasil. 
E é exatamente este legado que justifica a atenção desta pesquisa somente à experiência promovida pelo MASP, seja em virtude da sua amplitude temporal, como também, em virtude da consistência de suas proposições.

Como a pesquisa anterior, de caráter antológico, o presente texto contém um amplo levantamento das atividades expositivas dedicadas à discussão do design realizadas no Museu de Arte de São Paulo (MASP) entre os anos 1947 e 1989, anos da gestão de Pietro Maria Bardi. Destas atividades, foram destacadas e analisadas as fontes mais significativas para a contribuição à formação do pensamento no Brasil sobre o design. Vale lembrar que, a elaboração de uma análise crítica com o objetivo de constitui uma historiografia a partir de exposições, não se dedica a análise do objeto de cada uma das mostras, mas, sobretudo, dedica-se as intenções propositivas que orientaram a construção de cad uma delas. Vistas, enquanto conjunto, essas atividades oferecen um panorama geral das diversas questões propostas pelo Museu e sua contribuição para o debate da disciplina durante o período de consolidação do campo no País.

A pesquisa tem como problemáticas principais a complexidade da construção do campo e as relações entre a reflexão teórica e a produção. A importância desta abordagem localiza-se na possibilidade de traçar uma trajetória do desenvolvimento do campo deconhecimentonopaíspor meiodeumaabordagemhistoriográfica. Permitindo-nos ainda refletir, na contemporaneidade, sobre quais conteúdos e paradigmas deverão fundamentar a discussão sobre o campo do design para sua consolidação e contribuição ao contexto brasileiro. A esta última consideração, farei uma ressalva: na medida em que compreendo hoje e, sobretudo a partir do contato com as fontes e bibliografias disponíveis, é mais realista e necessário, na ausência de sistematizações historiográficas sobre o design e, m virtude disso, a também ausência de modelos analíticos con as corretas condições para evidenciar a complexidade do campo e, particularmente, as motivações de natureza antropológica; julgar esta pesquisa como uma oportunidade de compreender o "que é" ou o "que foi" o design brasileiro num esforço por evita vícios ou parcialidades que são verificadas em discursos dedicados ao "que deveria ser e não foi" o design brasileiro. ${ }^{3}$

Se as duas pesquisas tem objetivo semelhante - a reunião de fontes importantes sobre o debate do design no País - por outro, diferem no modo de organização. Em lugar de uma divisão cronológica, adotou-se aqui a divisão temática para a apresentação das exposições realizadas pelo Museu e; como resultado, são apresentados sete ensaios precedidos por uma breve introdução contextual. Essa escolha se dá na medida em que muitos dos temas são recorrentes ao longo de toda a atividade de Pietro Maria Bard como conservador-chefe do Museu ao lado de Lina Bo Bardi.

Estes ensaios, longe de limitarem-se a apresentação das exposições, têm como objetivo enunciar os principais temas propostos pelo Museu entre as décadas de 1950 e 1980 e contextualizá-los dentro do panorama da historiografia do design brasileiro. Os temas enunciados por eles surgiram a parti do contato com a totalidade das informações localizadas no longo processo de pesquisa em campo realizado no Museu. A partir da identificação das exposições; investigou-se o material relativo a cada uma delas encontrado nas pastas do Centro de Documentação do MASP; transcreveram-se os textos mais importantes dos quais não foi autorizada a reprodução por meio de fotocópia ou foto; solicitaram-se cópias daqueles autorizados, investigaram-se as imagens já localizadas por um processo de recuperação das imagens das exposições realizadas pelo MASP ainda em desenvolvimento na instituição; e por fim; tomou-se contato com o conteúdo identificado em cada umas das exibições. E é por meio do conhecimento dos temas e objetivos de cada uma das atividades que foi possível o agrupamento das exposições em diversas temáticas.

São pelo menos nove grandes temas enunciados, dos quais se privilegiaram sete para um maior aprofundamento. E das vária exposições que cada um deles abrigou; escolheu-se uma ou mais 
às quais o texto se dedica prioritariamente, seja pela consistência com que apresentam um argumento ou até mesmo pelo acesso um maior número de informações. Vale lembrar que são quase 42 anos de atividades realizadas no Museu e esta pesquisa está longe de esgotar as possibilidades de análise dedicadas à contribuição ímpar que Pietro Maria Bardi e Lina Bo Bardi realizam por meio das iniciativas propostas pelo Museu.

O primeiro ensaio - ExPOSIÇÕEs DidÁTICAS I - O OBJETO presenta as principais exposições nas quais é proposta a visão $\mathrm{d}$ objeto de uso cotidiano artesanal e industrial, enquanto elemento de arte. O objetivo é propor uma perspectiva ampliada do campo da arte, na qual o design é parte e tema de grande importância ao qual o MASP dedicar-se-á ao longo de várias décadas. Trata-se da tentativa de elaborar um discurso por meio das exposições que traga à luz a importância do objeto de uso cotidiano, cioso de seus valores técnico, histórico e estético; enquanto resultados de uma profunda compreensão de inúmeros aspectos de uma sociedade. Neste ensaio, duas exposiç̃es são fundamentais: a Exposiç̃̃o DA Cadeira, realizada em 1948, e a Exposição Vitrine das FORMAS, realizada em 1950.

Exposições Didáticas II - o GRÁfico é o título do segundo ensaio. Em continuidade ao primeiro, as artes gráficas são também aqui entendidas como arte e é justamente esta ideia que o museu proporápor meiodosseuseventos. AEXPosiçãoDidátICA DE ARTE Gráficas e o $1^{\circ}$ Salão Nacional da Propaganda, escolhido para ilustrar a discussão presente neste texto, não somente esboçam o conceito de arte defendido pelo Museu, como também antecipariam, com suas atividades de palestras, exibições de filmes, visitas a gráficas e aulas propostas, o interesse da institui-ção na formação de profissionais, que culminará na criação do IAC no ano de 1951. Ambas ainda reiteram por meio da ênfase a uma abordagem histórica, a convicção de que o processo criativo é resultante de uma ampla compreensão das técnicas, dos materiais e da cultura de uma determinada sociedade circunscrita numa época.
Em ExPosições DidÁTICAS III - MODA - a moda é também arte e porque é arte, a eleição da vestimenta deverá ser acompanhad de um juízo crítico informado. Assim como os ensaios anteriores, a compreensão ampliada do campo da arte, que inclui o design em todas as suas manifestações, é reiterada ao campo da moda. $\mathrm{O}$ discurso dedicado à moda estará presente em toda a gestão de Pietro Maria Bardi no Museu. E a este tema, somar-se-á a vontade de criar um acervo de indumentárias à maneira do Museu Metropolitan de Nova Iorque. Já nas primeiras atividades, na década de 1950 assim como para o campo da gráfica, as iniciativas do MASP não se limitaram à exposição ou desfile, mas são ampliadas à produção de roupas que exibam uma linguagem mais próxima das condições técnicas, históricas e estéticas nossas, como tentativa de inaugurar uma moda brasileira. Para esta reflexão, elegeram-se os eventos: Primeiro Desfile de Costumes Antigos e Modernos e Desfile Dior realizados em 1951; $1^{\circ}$ Desfile de Moda Brasileira no ano seguinte, 1952 e a exposição Traje - UM OBjeto DE ARTE? realizada em 1987.

O quarto ensaio, O Papel do MASP na Difusão do Discurso MODERNISTA, dedica-se às propostas expositivas que trazem ao Brasil a produção das vanguardas europeias modernistas e que tiveram por aqui um enorme eco na formação de grande parte do profissionais que atuaram nos anos seguintes no País. Inicialmente a proposição do discurso da estética moderna como a mais adequada às perspectivas da industrialização nacional parece se insinuar porém a prevalência do modelo de origem germânica como linguagem estética para o desenvolvimento do design no Brasi se dá muito mais por outras iniciativas e da própria conjuntura do País do que por uma proposição do Museu. O MASP entende o design como manifestação de arte e o modernismo é também uma manifestação entre estas. A defesa que o Museu fez à formação de um artista moderno se deu no entendimento do artista moderno enquanto sujeito que dominava materiais e técnicas de sua época e, não necessariamente, na defesa da adoção do vocabulário formal 
modernista. Ao contrário disso, o Museu foi também pioneiro em defender a consolidação de uma produção apoiada no conhecimento das tradições técnicas, estéticas e históricas do próprio País como forma de desenvolvimento de uma produção original. Este ensaio apresenta como objeto de discussão a fundamental Exposição MAx BILL, realizada em 1951.

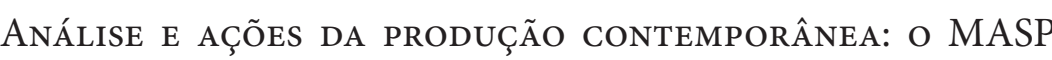
EXPONDO AS DEMANDAS DA SOCIEDADE BRASILEIRA, quinto ensaio, traz a reflexão em torno das exposições dedicadas à apresentação da produção industrial de diversos países e brasileira, sobretudo na década de 1970. Uma das possíveis justificativas à forte presença da produção industrial contemporânea, sobretudo, internacional no Museu, é a conjuntura econômica brasileira, mas também a aproximação de Pietro Maria Bardi à Federação das Indústrias do Estado de São Paulo (FIESP), com a morte em 1968 do fundador do Museu, Assis Chateaubriand, jornalista e proprietário dos Diários Associados. O objetivo dessas exposições, que trouxeram consigo modelos industriais internacionais apoiados nas fortes relações entre design e indústria, foi o aprofundamento da reflexão em torno da importância do desenvolvimento do produto industrial brasileiro com vistas ao processo de industrialização acelerada na qual o País estava imerso, bem como a tentativa de conscientização por parte do empresariado nacional acerca da importância do design como elemento central para o desenvolvimento da produção nacional que, não à toa, fortaleceu a iniciativa de estabelecer um diálogo com as indústrias paulistas. Em menor número, as primeiras exposições dedicadas à produção nacional são, sobretudo, as relacionadas ao mobiliário brasileiro. Fato já conhecido, é que a demanda imposta pela arquitetura moderna reconfiguraria primeiramente produção de mobiliário, na busca de uma linguagem em consonância com as novas orientações presentes nos projetos arquitetônicos. É somente no final da década de 1980, mais precisamente em 1989 que se localiza uma grande exposição com um panorama mais amplo da produção brasileira. sexto texto, O MASP, AS EXPosiç̃óES DEDICADAS AO DESIGN GRÁFICO BRASILEIRO E UMA NOVA CONFIGURAÇÃo ESTÉTICA ocupa-se das exibições do campo gráfico nacional e internacional, apresentando a reflexão em torno das relações entre arte e design presente, sobretudo na relação do Museu com a empresa italian Olivetti, patrocinadora de inúmeras mostras dedicadas ao tema no Museu. Vale ressaltar que as mostras dedicadas ao campo gráfico internacional demonstraram a presença de um maior pluralismo de linguagens estéticas, revelando uma proximidade maior em relação ao debate que se iniciara ainda nos anos 1960, no contexto internacional, momento no qual o panorama do design e da arquitetura contemporâneos fora enriquecido com nova contribuições mais atentas, a considerar o peso e as conquista do movimento moderno - a pós-modernidade. Já as exposições dedicadas à produção gráfica brasileira surgiram no Museu, à exceção dos Salões de Propaganda, em meados da década de 1970 As exposições dedicadas ao design gráfico brasileiro tem como traço comum a problemática da adoção de linguagens estéticas pouco afeitas às características culturais do País em virtude da implantação de modelos internacionais para o desenvolvimento a consolidação do design no Brasil. A maioria delas é dedicad à produção de expoentes do design gráfico brasileiro, sobretudo corporativo, voltados à criação das identidades empresariais. Faz-se uma exceção: a exposição História da Tipografia no Brasil dedicada a um mapeamento da Tipografia no Brasil desde a implantação da Imprensa Régia, no início do século XIX.

$O$ sétimo ensaio, O MASP, os BARDI E O LEGADO đ̀ DOCUMENTAÇÃO DO DESIGN E DA ARTE POPULAR BRASILEIRA, traz consigo a discussão das relações entre arte, artesanato e indústria; e é por meio desse extenso debate, proposto em inúmeras exposições, que Lina Bo Bardi explicita a convicção da necessidade do reconhecimento da produção pré-artesana a partir de um extenso levantamento das tradições, objetos e costumes da população brasileira; cujo objetivo é construir um 
inventário da cultura nacional como repertório fundamental para o desenvolvimento de uma produção industrial brasileir original e atenta às necessidades reais do País. Para este debate, a exposição A Mão do Povo Brasileira, realizada em 1969 se configura como a primeira grande mostra realizada na sede da Avenida Paulista, e seus desdobramentos são fundamentais.

Dois possíveis temas, para outros ensaios identificados ao longo das exposições relacionadas, são o tema das artes aplicadas ou decorativas, presente, na maioria das exposiçoes dedicadas, sobretudo, à produção em vidro - mais uma recorrência ao debate das relações entre arte, artesanato e indústria - e o outro, dedicado à discussão do ensino de design no País, seja por meio da exposição de trabalhos de alunos de faculdades de design ou por meio da exibição da experiência curricular de escolas dedicadas à formação de profissionais. A escolha em não incluí-los aqui, não faz deles questões menos prioritárias. Porém, as ausências justificam-se na medida em que o primeiro tema não estabelece elos tão fortes com a discussão voltada para a difusão e construção do design no País, objeto desta pesquisa, e, sobre o segundo tema, são pouca as exposições vinculadas à apresentação de experiências didáticas de outras instituições, na medida em que, vale dizer, grande parte das próprias iniciativas do Museu configuram-se em experiência didáticas fundamentais para a consolidação do design no Brasil.

Ao anexo desta pesquisa, coube o papel de apresentar brevemente a totalidade das exposições, bem como seus objetivos e as fontes localizadas no Centro de Documentação do Museu; tornando-se instrumento para futuras pesquisas àqueles interessados na análise e crítica da produção cultural para o design no Brasil

Deste amplo panorama, o destaque e análise dos principais temas recorrentes no discurso das exposições constituiu uma metodologia original para a consolidação da historiografia da disciplina, ao demonstrar a importância do discurso das exposições como importante reflexo do pensamento de uma época. E é justamente a análise deste discurso, realizada ao longo dos ensaios propostos, que permitirá o enriquecimento do panorama da área por meio do resgate de uma visão original do Museu para o design.

A problemática da construção do campo e a visão do MASP como hipóteses de pesquisa

Por meio da pesquisa desenvolvida durante o mestrado, fo possível identificar a problemática do significado como um dos paradigmas mais constantes no debate internacional e na pesquisas direcionadas ao tema desde os anos 1960. Retomase aqui, brevemente, a discussão proposta durante a dissertação de mestrado, dedicada às mudanças de significado contidas na noções de desenho industrial e design, com vistas a localizar a visão do campo do design proposta pelo Museu de Arte de São Paulo em suas exposições - objeto desta tese - dentro desse contexto.

Do ponto de vista histórico, é nos anos 1960 que o panorama da historiografia sobre arquitetura e design contemporâneos fo enriquecido com novas contribuições mais atentas a considera o peso e as conquistas do movimento moderno. ${ }^{4} \mathrm{Na}$ área de arquitetura, a publicação, em 1966, do livro COMPLEXIDADE ContRadição, de Robert Venturi, mudou radicalmente a atitude das pessoas em relação à arquitetura moderna. Soma-se também a influência de novos paradigmas externos à disciplina, sobretudo a fenomenologia e as teorias da comunicação, que passam a acrescentar novos modos de abordar a sua crise, inaugurando um período de reexame na arquitetura. ${ }^{5}$

Contemporaneamente também foi possível identificar uma crise da noção de desenho industrial. A historiografia do design surgiu de modo militante fortemente ancorado a motivações não somente culturais, mas morais e políticas. Pioneiros nesta abordagem à história do movimento moderno em arquitetura foram Pevsner e Gideon, os mesmos autores que inauguraram a historiografia sobre o desenho industrial. ${ }^{6}$ Tal vínculo revela que a noção esteve, desde então, condicionada pelos ideais do movimento moderno. No entanto, nos mesmos anos 1970, com a crise do moderno, 
somam-se também novas contribuições à área, sobretudo, a partir das obras de Reyner Banham e Tomás Maldonado. ${ }^{7}$

Assim, a noção de desenho industrial, como fora genuinamente definida, não pareceu ser mais suficiente para incluir os contextos distintos em que o designer é chamado para atuar pelos desenvolvimentos do capitalismo contemporâneo. É neste mesmo período que a literatura internacional abandona nomenclaturas como 'industrial design', que fora traduzido como 'desenho industrial', enfocando, sobretudo, o desenho do produto, e passa a utilizar somente o termo inglês 'design', com significado mais amplo, incluindo as complexas relações entre a produção e os aspectos tecnológicos, sociais, políticos e psicológicos que a envolvem.

No Brasil, o debate sobre o desenho industrial ganha contornos significativos somente a partir do processo de industrialização acelerada promovido pelo Estado a partir dos anos 1950; sendo totalmente vinculado à difusão do projeto moderno no continente americano. Este descompasso não deixou de ter reflexos também no discurso sobre o tema da caracterização de um design brasileiro. Se, nos anos 1970, grande parte da literatura nacional preocupouse em esclarecer o significado da disciplina em questão; em âmbito internacional, tal noção já apresentava uma crise de sentido.

Nos últimos anos da década de 1950, foi possível identificar contribuições que refletem e questionam a validade dos conteúdos de matriz racional-funcionalista no âmbito brasileiro. ${ }^{8}$ Nos ano 1960, as colocações de Décio Pignatari, influenciadas pelas teorias da comunicação semiótica, já reveem aspectos da raiz modernista contida na noção de desenho industrial. ${ }^{9} \mathrm{E}$ é possível localizar artigos no Brasil que se utilizam somente do termo 'design' num sentido mais amplo já em 1971. ${ }^{10}$ Porém, é em 1979, no Encontro Nacional de Desenho Industrial (I ENDI) realizado no Rio de Janeiro, que se decide identificar a profissão como desenho industrial, com as habilitações desenho de produto e programação visual no País e, somente em 1988, no workshop O ENsino DO
DESIGN NOS ANOS 90, realizado no bairro de Canasvieras em Florianópolis, Santa Catarina que, por meio da elaboração do documento, Carta de Canasvieiras, afirma-se em definitivo o uso do termo design, com os desdobramentos: design e produto e design gráfico. ${ }^{11}$

Portanto, neste contexto, é possível compreender a noção de 'design' como superação dos significados atrelados ao movimento moderno presentes à noção de 'desenho industrial.' 'Design', no contexto da pós-modernidade, passa a conter outros significados, ainda pouco definidos, que não se relacionam somente aos aspecto materiais e projetuais do objeto, mas, sobretudo, com o conjunto da experiência humana construída pelos objetos produzidos.

Atualmente, o significado do termo 'design' parece definir a construção de significados a partir das relações que o homem estabelece com seus objetos. Portanto, a posse de um determinado objeto é capaz de construir representações, significados invisíveis, que passam a determinar o reconhecimento do indivíduo em sua esfera social e dessa forma, estabelecer um ambiente artificial - uma experiência particular - do indivíduo sobre si mesmo. O projeto va lém dos aspectos funcionais e materiais e compreende a concepção de significados intangíveis impregnados na materialidade do objeto.

As noções de 'desenho industrial' e design assemelham-se a Arias relativas, surgem como tentativas de compreensão dos processos e dinâmicas circunscritas, sobretudo relacionada aos objetos em uma sociedade num determinado período de tempo e, portanto, passíveis de superação, por seus caracteres de complexidade e perenidade. Entretanto, vale reiterar que o sentido de superação, aqui proposto, está longe de ser uma abordagem evolucionista, mas o entendimento do caráter de superação como mudança necessária: compreendendo-se a natureza humana como dinâmica e, se consideradas as motivações antropológicas do campo do design, torna-se evidente a impossibilidade de um caráter definitivo e atemporal. 
A este debate, no entanto, soma-se uma visão completamente original para o panorama da historiografia da disciplina no País. Ao contrário de grande parte das reflexões presentes no debate da disciplina durante a segunda metade do século XX, cuja bandeira foi a construção de fronteiras claras a outros campos do conhecimento e, particularmente, à arte, como forma de afirmação O Museu, desde sua fundação, ao adotar uma visão ampliada do campo da arte - arte como consequência do meio - compreenderá, sem distinções, o design como arte. Por esta afirmação, o design é compreendido como elemento fundamental da cultura como um todo, e condição necessária para configuração do ambiente cotidiano.

Esta compreensão, que se afasta de um entendimento do design enquanto disciplina estritamente vinculada ao processo de industrialização, tem em vista arte e design como manifestações que se dão em consequência do meio, ambas como respostas às condições técnicas, históricas e estéticas de uma determinada cultura em espaço e tempo específicos.

O Museu ao afirmar ou compreender as manifestações de arte $\mathrm{e}$ design como importantes registros da cultura de uma determinada época, reflexo da multifacetada complexidade, desejos e atitudes de uma sociedade; retoma uma convicção que tem suas raíze no campo da antropologia e, prioritariamente, na arqueologia enquanto disciplina que vê toda a materialidade de uma cultura, seja ela de valor artístico ou ordinário, como um fato ou elemento significante para a compreensão do pensamento, dos valores da sociedade à qual estes pertencem.

Ao retomar exemplares originais de séculos passados conjuntamente com a produção contemporânea nas várias exposições propostas, o Museu, ao valorizá-los como resposta mais adequada às técnicas, materiais e conteúdos próprios de sua época - retomando a ideia de uma "moral" do objeto ou de qualquer manifestação que tem como atributo a configuração da experiência humana - reforçará uma visão da disciplina enquanto cultura material, expressão própria das disciplinas abrigadas pelo discurso antropológico. A presença, colaboração de Emilio Villa, poeta e artista italiano cuja criatividade artística tem profundas raízes em estudos filológicos ${ }^{12}$, nas primeiras atividades do Museu e na fundação da revista Habitat, é ainda tema a ser amplamente pesquisado para maiores considerações sobre as relações de uma visão arqueológica para os campos da arte e do design e sua influência no ambiente brasileiro e, sobretudo, nas iniciativas propostas pelo Museu.

Considerada esta posição, é possível afirmar que o MASP anteciparia, desde a sua fundação e ao longo de suas atividades, uma visão avessa a discursos restritivos e, coincidentemente, mais próxima ao debate contemporâneo do design. No qual design é resposta às exigências da modernidade e, estas exigências, condicionadas às relativas noções de espaço e tempo, determinam a complexidade da disciplina. Tal conceito vem reiterar mais uma vez a presença de motivações antropológicas nas atuais abordagens da disciplina, as mesmas que influenciaram a visão do Museu para o campo do design.

Esta leitura pretenderá, ao menos, configurar-se como uma contribuição valiosa, porém inicial, do importante papel do Museu para a difusão e construção do design no Brasil e oferecer uma base oportuna à teoria e prática do design na atualidade 


\section{N OTAS}

1. Na gíria italiana, pallino refere-se a quem se interessa por um determinado assunto, uma mania.

2. É importante salientar que se adotará a nomenclatura 'design' em todo o texto desta tese, ainda que nas décadas de 1950 e 1960 a literatura da disciplina refira-se a 'desenho industrial'. Na dissertação de mestrado que precedeu esta pesquisa identificou-se que na expressão 'desenho industrial' está contido um significado diverso da noção de 'design' nomenclatura adotada para a disciplina a partir dos anos 1970 no Brasil. No entanto, o MASP apresenta uma visão original à concepç̃o da disciplina, na qual 'desenho industrial' e 'design', bem como a 'arte' são a um só tempo expressão de um amplo processo de compreensão de pelo menos três aspetos: históricos, técnicos e culturais (estéticos) de uma sociedade. Esta questão será amplamente considerada ao longo do presente texto.

3. Este pressuposto de uma construção historiográfica menos parcial está presente no modelo analítico proposto por Andrea Branzi para a análise crítica do design italiano em: BRANZI, A ndrea.Il design come cultura civile. In: II Design - II design italiano 1964-2000. Electa:2008.

4. CASTELNUOVO/ GLUBER/MATTEONI. Enrico/ Jacques/ Dario L'oggetto misterioso. (In CASTELNUOVO, Enrico (org.) Storia del Disegno Insdustriale - 1919-1990 II domínio del design. Milano: Electa, 1991. p. 406.

5. NESBITT, Kate. In NESBITT, Kate (org.). U ma nova agenda para a arquitetura: teórica (1965-1990). São Paulo: Cosac Naify, 2006. p. 11

6. CASTELNUOVO/ GLUBER/MATTEONI. Enrico/ Jacques/ Dario. L'oggetto misterioso. (In CASTELNUOVO, Enrico (org.) Storia de Disegno Industriale - 1919-1990 II domínio del design. Milano: Electa, 1991. p. 405.
7. Idem, p.406-407.

8. Artesanato e indústria. Habitat (9), 1952. p. 86

9. PIGNATARI, D. A profissão de desenhista industrial. Arquitetura (21), 1964. p. 25-28.

10. Design: Arnold Wolfer, designer. Casa \& Jardim (198), 1971 p. 24-27; Design: Geraldo de Barros. Casa \& Jardim (199), 1971 p. 24-27; N ovas tendências do design francês. Casa \& Jardim (201) 1971. p. 8; PAPANEK, Victor. Depoimento: 0 que é design? (trad.) REZENDE, Marco Antônio Amaral. C. J. Arquitetura (5), 1974. p. 12-6 entre outros

11. REDIG, Joaquim. Um encontro histórico. Design \& Interiores, n.10, 1988.

12. A filologia é a ciência que estuda uma língua a partir de uma visão histórica, sob a ótica da evolução intelectual dos povos e seus sinais, de forma geral, a partir de documentos escritos. 
Ao longo dos mais de quarenta anos, de 1947 a 1989, em que Pietro Maria Bardi foi o diretor-conservador ou conservadorchefe, posição na qual exercia o papel de mentor intelectual do museu, não somente responsável pelo acervo, mas também pelas exposições apresentadas e pela política cultural do museu; é possível identificar mais de 130 exposições relacionadas direta ou indiretamente à discussão do design, o que evidencia não somente o interesse em relação ao tema, bem como a profunda contribuição à consolidação do campo no país po meio de proposições e debates manifestados por exposições, conferências, desfiles e atividades didáticas realizadas pela instituição ao longo da segunda metade do século XX. E é por meio desses inúmeros eventos que se pretende aqui trazer ao conhecimento não somente a contribuição do Museu para o design, mas também resgatar a originalidade de um legado sem precedentes na história das instituições culturais brasileiras.

\section{O PROJETO DE UM PAÍS \\ EM TRAN SFORMAÇÃO}

A fundação do Museu, em 1947, na perspectiva dos acontecimento internacionais, se dá no período pós-Segunda Guerra Mundial. Se por um lado a herança da guerra é trágica; por outro, os avanços tecnológicos e produtivos são de fundamental importância para o desenvolvimento do design ${ }^{2}$.

Alguns países americanos e, entre eles, o Brasil, se beneficiaram da economia de guerra graças ao aumento do volume das exportações de insumos agrícolas. A crise europeia e a incapacidade de produzir e suprir a própria demanda favorece o crescimento de uma série de países periféricos, que se veem diante da necessidade de substituir artigos costumeiramente importados. Para o Brasil, essa condição, aliada a uma política nacionalista e desenvolvimentista promovida por Getúlio Vargas, favorecerá a formação do parque industrial brasileiro.

Em âmbito internacional, com o significativo crescimento do parque industrial norte-americano - o país se tornara o principal fornecedor de quase todos os tipos de equipamentos e insumo consumidos durante o período mais crítico da guerra - e ainda, com os vultosos investimentos na produção de equipamentos militares por grandes empresas norte-americanas, era necessário o redirecionamento da produção industrial.

Uma série de soluções é adotada como estratégia para o escoamento da produção. O Plano Marshall foi uma das soluções para evitar a desaceleração da produção e o desemprego generalizado, já que muitas empresas norte-americanas haviam elevado a sua capacidade produtiva em níveis muito superiore às demandas tradicionais. $\mathrm{E}$ é por meio dele que são criadas as condições políticas e financeiras para o auxílio norte-americano aos países arrasados pela guerra. Outra solução foi a manutenção da produção de um grande volume de armamento militar e incentivo 
ao consumo dos países aliados: solução esta que seria bastante favorecida pelo contexto da Guerra Fria. E a última, foi dar un novo direcionamento à capacidade produtiva com a transformação de linhas industriais dedicadas à produção de artefatos militare para linhas voltadas à produção de bens de consumo.

O mercado norte-americano já apresentava sinais de saturação desde o final da década de 1940 e para a manutenção dos elevado padrões de consumo era necessário estimular a constante troca de produtos por novos. O cartão de crédito surge na década de 1950, justamente como uma forma de garantir o poder de compra, por meio da ampliação do crédito. E é exatamente a concessão de crédito como instrumento de crescimento econômico que impora uma significativa transformação nos padrões de consumo da sociedade norte-americana. É a passagem de um estágio de consumo simples para uma nova condição de consumo: na qual a abundância e o desperdício são condições essenciais para a manutenção da economia produtiva. Nos anos 1950, com o acirramento da Guerra Fria, o modelo de consumo irrestrito supera fronteiras e passa a ditar políticas em escala internacional.

No Brasil, em 1951, Getúlio Vargas assume novamente a presidência do País por meio de eleições realizadas no ano anterior. O governo de Getúlio promove uma série de medidas para incentivar o desenvolvimento econômico, com ênfase à industrialização por meio de inúmeros investimentos em sistemas de transporte e energia, do sistema portuário e da criação, em 1952 do Banco Nacional de Desenvolvimento Econômico (BNDE) e da Petrobras, em 1953. No mesmo ano, estabelece o câmbio flexível como forma de capacitar a competição de mercadorias exportadas e favorecer a importação de bens considerados necessários para desenvolvimento do País. A esta medida, soma ainda a introdução do confisco cambial: ao fixar um valor mais baixo ao dólar, recebido pelos exportadores de café, tem como objetivo deslocar as divisas arrecadadas pela exportação de café para outros setores e, prioritariamente, para a indústria.
Desde o início da experiência democrática no país, em 1945 o processo de industrialização é favorecido por meio de medidas econômicas que buscam o equilíbrio da balança de pagamentos. Os recursos, antes empregados na produção cafeeira, passam ser empregados na consolidação de um setor industrial voltado para o mercado interno e capaz de diminuir a dependência do País à importação.

Do ponto de vista político, essas medidas causam inúmeros protestos da ala mais conservadora e a estes, é adicionada a frustrada tentativa de assassinato do jornalista Carlos Lacerda por Gergório Fortunato, chefe da guarda presidencial, acontecimentos que favorecem o precoce encerramento do governo de Getúlio com o dramático suicídio do presidente.

Quem o sucede, em 1956, é Juscelino Kubitschek, que inaugura o período desenvolvimentista com o famoso lema "cinquenta ano em cinco" e com a simbólica imagem da construção da nova capital do país, Brasília, durante os cinco anos de seu mandato.

O desenvolvimento proporcionado pela consolidação de um parque industrial no Brasil ocorre dentro das regras impostas pelo contexto internacional: a ampla inserção de capita estrangeiro como base da política de incentivos à industrialização. O desenvolvimento industrial é também estimulado de form emelhante em uma série de nações na América Latina como form de ampliação dos mercados de consumo e inserção nas relações de comércio internacional.

O desenvolvimento promovido pela consolidação de um parque industrial teve como objetivo prioritário a formação de uma classe média brasileira inserida no processo de industrialização, tanto do ponto de vista das oportunidades, como também do acesso ao produtos que passam a ser produzidos no país. Pretendia-se formar uma ampla classe média capaz de consumir de maneira semelhante aos padrões norte-americanos de consumo.

O período desenvolvimentista, de fato, promove um indiscutível crescimento do País, no entanto, vale lembrar que,naquele 
momento, a grande parte da população brasileira é agrária participa do processo de desenvolvimento de forma marginal. A concentração dos investimentos no sudeste é uma decisão tomada em função de um melhor aproveitamento da infraestrutura instalada; porém essa concentração favorecerá um grande fluxo migratório de trabalhadores rurais em busca de trabalho nas grandes cidades, contribuindo para o adensamento urbano, sobretudo no estado de São Paulo.

A ausência de um projeto de infraestrutura, capaz de atender às necessidades dos grandes contingentes populacionais que migram às grandes cidades, culminará na formação de extensas periferia e favelas, áreas de sobrevivência que revelam a fragmentação e o contraste do tecido urbano. Outro aspecto fundamental o conflito de uma população rural que é colocada frente a novo hábitos e aspectos culturais que, muitas vezes, em nada lembram a experiência de seus antepassados. O drama do choque de valores e identidade é agravado com a inserção da população na nova realidade de tempo e espaço, determinada pelas condições urbana e operária.

É em meio a um período de profundas e aceleradas mudanças políticas, econômicas e sociais que o Museu de Arte de São Paulo (MASP) é fundado. E é justamente este contexto de ênfase à industrialização no país que favorecerá a consolidação do campo do design no Brasil. As políticas econômicas, ao privilegiar a atividade industrial como o fator essencial do desenvolvimento e a inserção de estruturas internacionais de produção (as multinacionais) propiciariam o ambiente favorável para o surgimento de debates em torno da atividade do design no País.

\section{EXPOSIÇÕES DIDÁTICAS I \\ O O BJETO}

A Exposição DA CADEIRA é a primeira exposição proposta pelo MASP dedicada à discussão do objeto de uso cotidiano, uma iniciativa de Lina Bo Bardi, com a colaboração do arquiteto Giancarlo Palanti, Dr. G. Giacomini e o pintor Eurico Camerini. Considerada a primeira exposição da série "Artes Industriais" é aberta em 14 de setembro de 1948 na sede do Museu, recém-instalado à Rua 7 de Abril, e teve caráter didático, objetivando abordar o objeto cadeira sob os pontos de vista: técnico, estético e histórico.

A viabilização da exposição contou com a participação da sociedade paulista. Meses antes, é divulgada uma nota pública na qual são solicitadas colaborações à proposta: seja por meio de qualquer tipo de cadeira antiga, catálogo velho, desenhos, modelos; tudo que possa servir para o estudo da importante peça de mobiliário ${ }^{4}$. A própria concepção da mostra enfatiza o caráte didático, na medida em que é dividida em duas partes: "uma gráfica, esclarecedora do progresso e da evolução da cadeira, e uma parte de exibição de objetos característicos." 5

$\mathrm{Na}$ parte gráfica foram exibidos oito ou onze painéis demonstrativos, os textos publicados em torno da exposição divergem sobre o número exato. São centenas de fotografias reproduções de catálogos dispostos em ordem cronológica, como proposta para um estudo histórico do desenvolvimento das formas da cadeira. Um dos painéis dedicava-se a apresentar exemplare de cadeiras da Antiguidade: Egito, Mesopotâmia, Grécia e Roma a partir de fotografias tiradas de cerâmicas próprias de cada civilização. Outros: a Idade Média, dedicado a cadeiras do século V o XIV; à Renascença; aos séculos XVII e XVIII; ao fim do século 


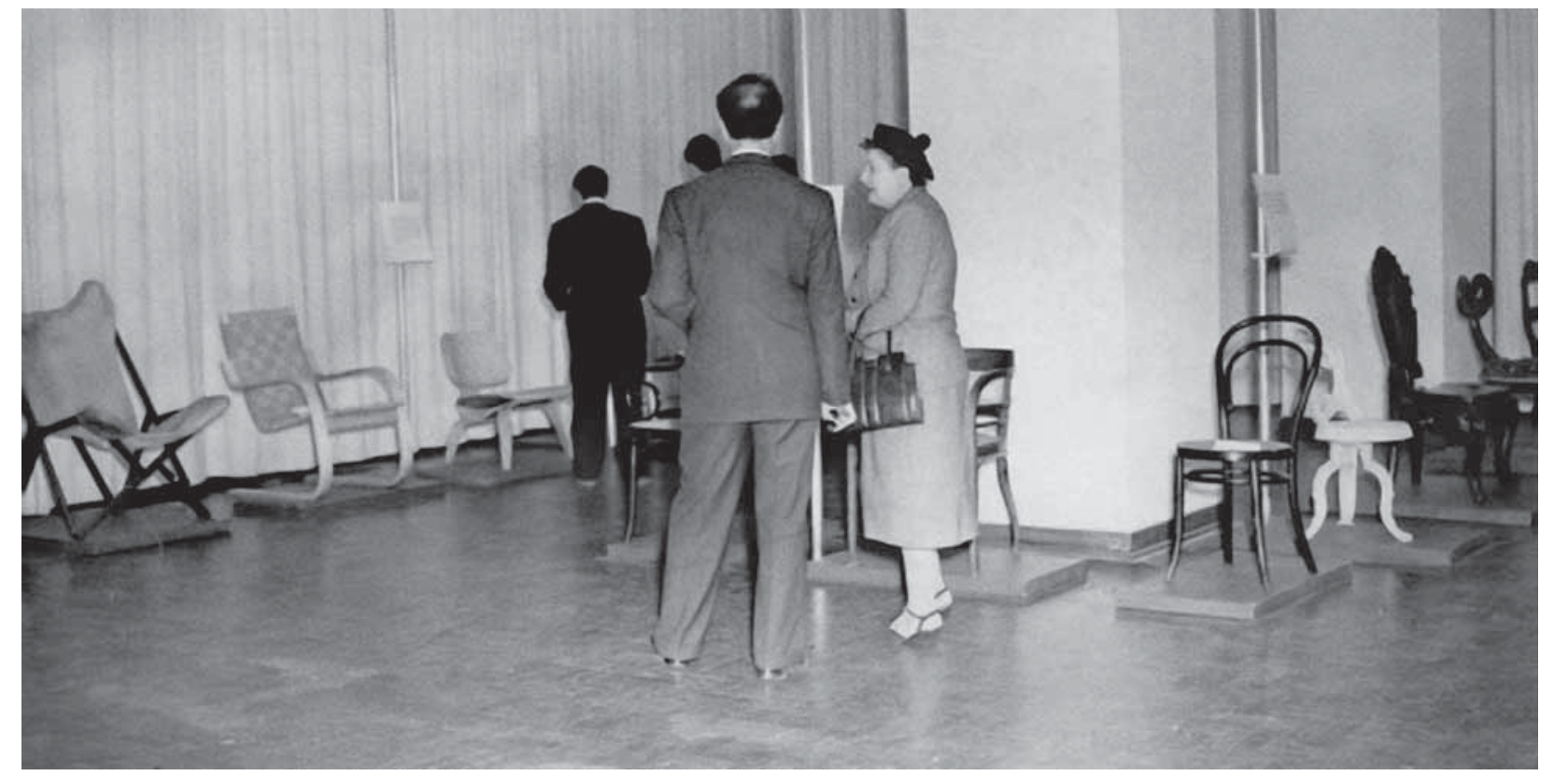

“Expor a forma da cadeira: esta foi a primeira ideia da nossa exposição. A ideia foi simples, mas difícil foi a realização dessa manifestação.Tratava-se, entretanto, de organizar o histórico da cadeira, da pré-história até nossos dias.

(...) Este trabalho conduziu à seleção dos modelos: eliminaramse do histórico todas as derivações de estilo.Por exemplo: sabese que os estilos franceses, desde Luís XIV até o N apoleônico, tiveram repercussão em todo o mundo; mas na mostra figuram os tipos originais e só assinalaram-se os casos em que tipos derivados apresentavam sensíveis inovações. Deve-se ter presente que cada decorador, artesão ou marceneiro, gosta de fabricar a seu modo: é por isto que há no mundo milhões de cadeiras diversas. A maneira de sentar-se é uma só, as regras técnicas para dar inclinação a um encosto são fixas; mas as

XVIII e início do XIX; à Industrialização; ao Art Nouveau e o último, dedicado aos exemplares contemporâneos.

A investigação no acervo histórico do MASP permitiu verificar que, para a maioria das exposições propostas pelo Museu, fo redigido um texto com a explanação das intenções e objetivo de cada uma das propostas expositivas; na maioria das vezes não assinado, mas de provável autoria de Pietro Maria Bardi ou Lina Bo Bardi, muitos deles são manuscritos em italiano. Esses textos, provavelmente dirigidos à imprensa e à própria exposição, são documentos fundamentais que nos aproximam das reflexões acerca de cada uma das iniciativas.

A reprodução desses textos por meio de imagens ou cópias não permitida pelo Museu, somente a transcrição direta dos mesmos, o que exigiu inúmeras horas de pesquisa detidas a essa tarefa.

Entretanto, é fundamental o discurso proposto e vale a pena 02 Expo SIÇÃo da CADERA 1949 deter-se em alguns trechos:

Foi nesta babel de criações, em que se constata a extraordinária eficiência da fantasia, que se estabeleceu uma espécie de ordem para nosso histórico: da pedra sobre a qua se sentava 0 homem das cavernas até à magnífica invenção de C harles Eames - construir a cadeira em madeira compensada e curvada segundo partes do corpo inconstantes, as várias peças estando ligadas por juntas de borracha. (Aliás, esta cadeira fo o sucesso da exposição).

Até a época da industrialização as cadeiras eram expressões mais estéticas do que funcionais. E eram verdadeiras "peças únicas".

(...) no século XIX assistimos a um estranho predomínio de formas "artísticas", segundo o estilo não-unitário da época. E neste século que a sociedade, mecanizando-se, se industrializa. A industrialização permite a repetição até 0 infinito dos estilos 
de todas as épocas em formas híbridas.

Mais tarde a industrialização acha sua primeira expressão estética, depois das tentativas híbridas de repetição dos estilos nas cadeir as da firmaT honet deViena. Já no começo do presente século, a especialização alcança a fabricação dos móveis que perde assim a sua secular superposição decorativa para assumi a forma rigo rosa derivada da sua pesquisa fisiológica.A primeira manifestação orgânica de estudo de desenho industrial fo a "Bauhaus" de Dessau - 1919 a 1928 - chefiada por W alter Gropius e Marcel Breuer.

Tivemos a seguir as cadeiras ideadas e construídas por vários arquitetos contemporâneos, todos empenhados em criar um assento que satisfizesse as necessidades do homem de hoje em dia: hoje, mais do que nunca, com os conhecimentos dos materiais e das técnicas que possuímos, deve-se ter presente que a cadeira não é um monumento; serve para sentar-se.

Também o móvel tem sua moralidade e sua razão de ser na sua própria época. A cópia dos estilos passados, os babados as franjas, as "originalidades" são índices de mentalidades incoerentes, fora da moralidade da vida. A criação popular, alheia aos problemas exibicionistas, é a que mais se aproxima das formas modernas alcançadas pela especialização.

Todas as fases históricas da cadeira acima registradas ficaram documentadas em nossa exposição que, de grande utilidade didática para o público, levou-o a perceber que a simples escolha de um objeto insignificante, é de grande importância para o conjunto harmônico e funcional da casa."

A EXPOSIÇÃO DA CADEIRA é a primeira exposição da série ARTEs NDUSTRIAIs e, na sua primeira proposição, o Museu já enuncia sua concepção da arte, concepção esta antecipada no próprio título da série e que orientará grande parte da reflexão proposta pelo museu ao longo da direção de P. M. Bardi. A exposição, em conjunto com outras, revelará uma compreensão ampliada do próprio campo da arte na qual o objeto de uso ordinário, cuja concepçao é tarefa ao qual se ocupa o design, ou desenho industrial àquele período, é também entendido como manifestação de arte, por meio de três atributos fundamentais: estético, histórico e técnico. E é justamente por meio da escolha da cadeira, objeto de fácil reconhecimento, que se pretende revelar ou "ensinar", vale aqui o caráter didático da mostra, sobre a importância do universo dos objetos a partir de uma compreensão mais ampla do papel dos mesmos em relação ao homem e a sua cultura.

Boa parte da literatura dedicada ao relato da Exposiç̃̃o DA Cadeira dá ênfase à cadeira Thonet. Trata-se de um equívoco limitar a proposta expositiva a esta consideração. A proposta tem como objetivo trazer à discussão uma percepção completamente original para a sociedade paulista sobre a importância do objeto, por meio de três aspectos: o caráter técnico, no qual existem regras fixas que determinam qualidades de uso, e no caso da cadeira, trata-se do conforto por meio da inclinação correta; o caráter histórico que corresponde a uma concepção do objeto coerente com o contexto temporal em que se dá:

“(...) Também o móvel tem sua moralidade e sua razão de ser na própria época. (...)" 7 e que, condena anacronismos:"(...) A cópia dos estilos passados, os babados, as franjas, as "originalidades" são índices de mentalidades incoerentes, fora da moralidade da vida. $(. .) "$.

e a compreensão do objeto como elemento significativo da cultura material, ao valorizar a criação popular que, ao dispensar uma pretensa estetização, revela saberes: o domínio de técnicas materiais próprios que a aproximam das formas modernas, próprias 


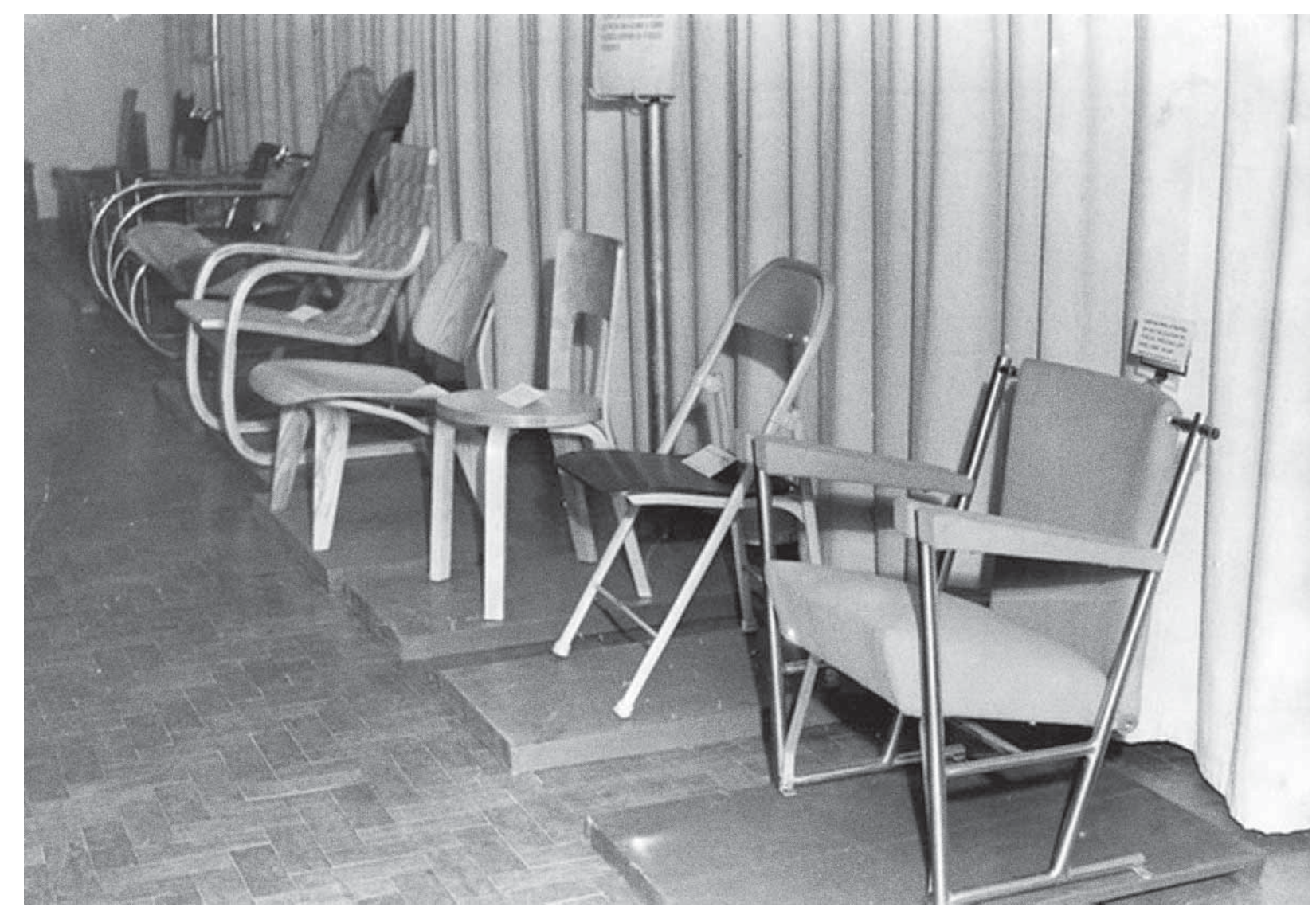

da industrialização

A valorização da criação popular como expressão significativa da cultura material de uma sociedade e, sobretudo a aproximação à produção moderna se dá justamente por uma compreensão singular do campo da arte, no qual se inclui o design, a partir do trinômio técnica, estética e história. Essa compreensão ampla permitirá que inúmeras exposições no Museu versem ora sobre artesanato, ora sobre indústria. Basta citar que em 1949 ocorre a primeira grande exposição de arte popular dedicada à cerâmica nordestina, ARTE Popular Pernambucana ${ }^{9}$ que, longe de evidenciar um conflito 03 Expo sição DA CADERA 1949 Documentação do MASP entre os saberes produtivos, encontra uma conciliação, na medida em que ambos refletem conhecimentos de técnicas e materiais
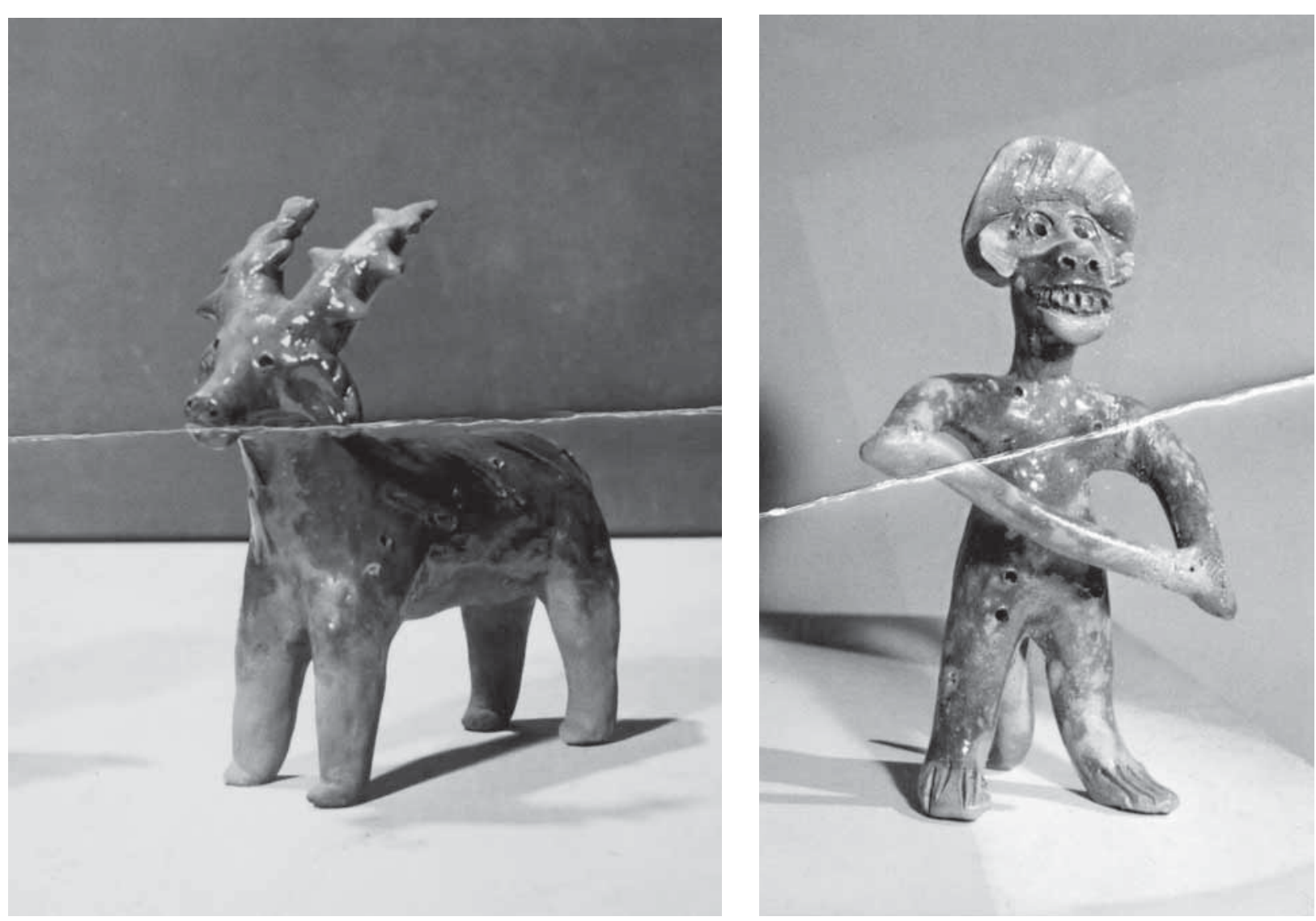

próprios de uma cultura num espaço e tempo específicos.

debate proposto pelo Museu suscitou manifestações na sociedade da época, nem sempre compreendido, que é revelado por meio de nota publicada:

04 1 Expo sição de Arte Popula Centro de Documentacõo do MASP

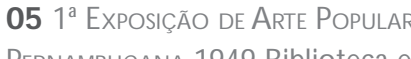
Centro de D ocumentaçãa do MAs
"Inaugurou-se no Museu de Arte a Exposição da Cadeira. Esse móvel que a inteligência trepidante de Van Gogh uma vez selecionou entre os objetos que havia de transmitir em arte..

(...) Algumas considerações foram bem apresentadas nesta organização: a questão moral que situa o objeto em relação ao 
homem, certas considerações críticas. 0 tema continua muito alto, porém, não é possível impô-lo a ninguém. Mas a iniciativa mesmo que permaneça incompreendida, vale. Ela tem a seu favor a boa escola, a boa orientação. É sério que se observe a verdade de um objeto. E esta exposição se orienta neste sentido. N ão se trata de algo gratuito, ou abstrato, como teme o sr. Di Cavalcanti.

Portanto, dona Lina Bo Bardi e os seus colaboradores nesta organização merecem as melhores felicitações. (...) Estas simples situações do homem na gradação das épocas são coisas vivas. 0 importante é sentir o seu coração e confirmar que palpita. $\mathrm{Na}$ incipiência de nossa vida, haveria eu de prestar atenção ao capítulo do desenho industrial, organicamente considerado.

Pela primeira vez, no Brasil, acha-se exaltada, de maneira inteligente, a importância singular da escola de Gropius, o Bauhaus de D essau." 10

No ano seguinte, 1950, em continuidade à proposta de caráter didático para o campo do design, já iniciada com a ExPosição DA CADEIRA, é inaugurada com a mesma abordagem a exposição VITRINE DAS Formas, mostra permanente de objetos expostos em uma grande vitrine concebida para o Museu.

“Esta exposição tem um sentido museológico diferente: não pretende ser apenas uma apresentação de objetos "antigos", mas uma reunião em conjunto de formas variadas, criadas por civilizações diferentes ou originadas simplesmente por circunstâncias casuais, mostrando a variabilidade da fantasia humana na criação e modificação dos materiais, dentro de um mpulso renovador incessante.

A maioria das pessoas costuma encarar a forma com certa

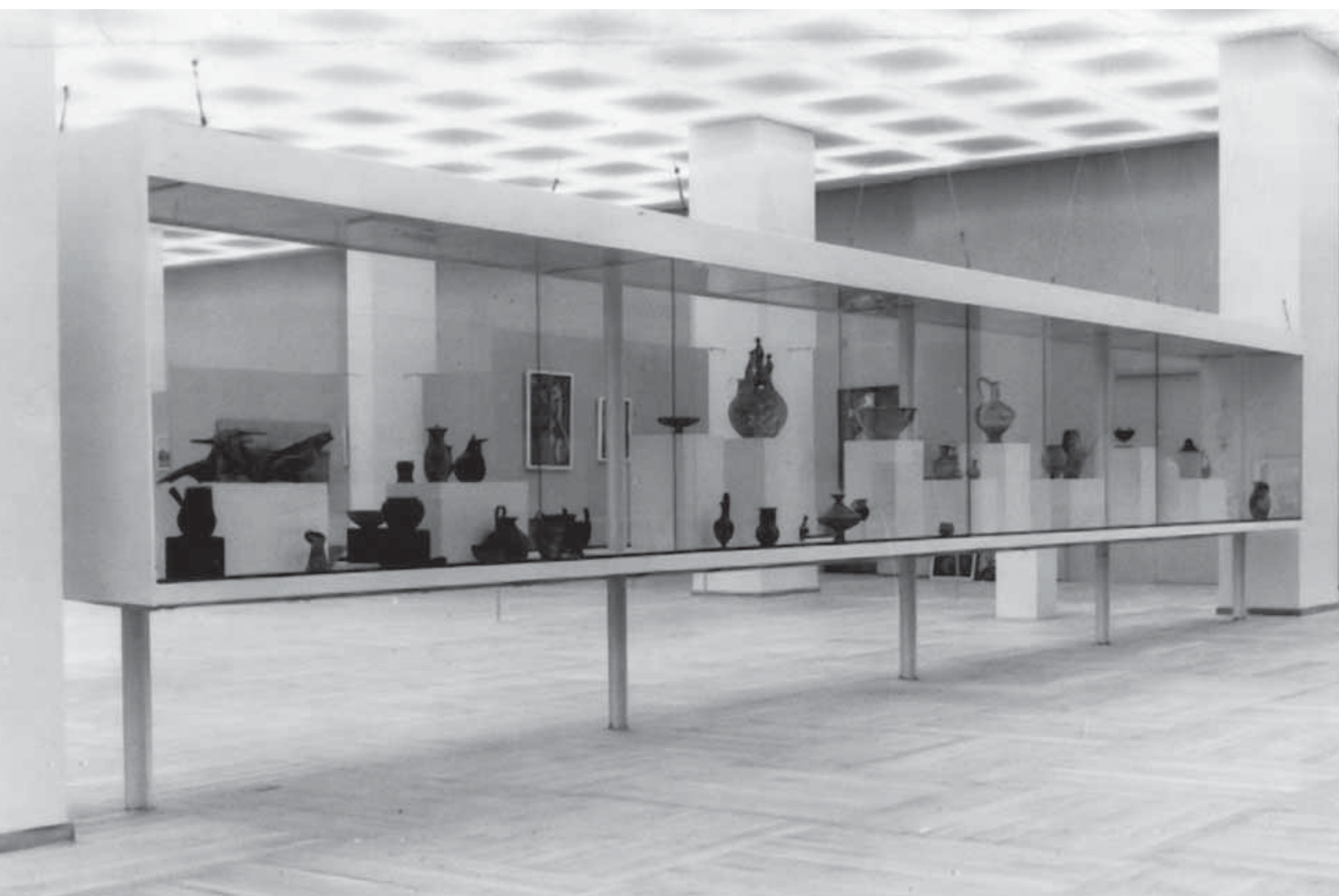

indolência visual, isto é, com certa falta de discriminação ou espírito de comparação, quase sempre sem nenhuma preocupação crítica, adquirindo um copo ou um aparelho de rádio, uma máquina de costura ou um vaso, sem consciência da importância e responsabilidade que a entrada de uma nova forma representa para a casa. (Verdade é que na maioria das vezes a própria arquitetura da casa obedece à mesma indiscriminação (sic) de valores e de gosto)

Esta exposição visa, portanto, despertar a atenção sobre: proporção, racionalidade, inteligência, gosto, arte e historicidade de toda e qualquer forma com a qual se entra em contato. De
06 Vitrine das Formas 1950 Dibioteca e Centro de entro desse critério orgânico e didático. Todos os objetos 
O texto dedicado à exposição segue com categorias históricas nas quais os objetos foram reunidos e apresentados, de modo bastant semelhante à divisão proposta para os painéis didáticos elaborados para a EXPosição DAS CADEIRAS. A vitrine é praticamente o resultado tridimensional das proposições visuais presentes nos cartazes da exposição que a precedeu.

Os documentos escritos sobre a VITRINe DAS Formas são escassos, porém, ao registro fotográfico somam-se os depoimento de personagens de toda uma geração precursora para o campo do design no Brasil. As imagens e os depoimentos são as melhores fontes de documentação para revelar o significado ímpar da proposta para a década de cinquenta no País. Vale lembrar o depoimento do designer gráfico Alexandre Wollner, à época, aluno do Instituto de Arte Contemporânea do MASP (IAC), no qual comenta o impacto da exposição para a formação dos designers e artistas brasileiros:

“Um dia, vi uma vitrine cheia de potes egípcios, astecas, e, ao ado de diversas outras antiguidades, uma máquina O livetti. Fui falar com o Flávio Motta, que era assistente do Bardi: "Acho que esqueceram uma máquina de escrever na vitrine..." o Bardi se interessou pelo sujeito que havia dito aquilo e veio me explicar que a máquina de escrever era a mesma coisa que o pote na época do pote:um objeto útil, que fazia parte da cultura de um grupo primitivo, assim como a máquina faz parte do nosso grupo.

Foi então que comecei a perceber essas coisas." ${ }^{12}$

07 VITRIN E das Formas 1950 Biblioteca e C entro de Documentaç̃ão do MASP 08 VITRINE DAS Formas 1950
Biblioteca e C entro de Documentaçãa do MASP

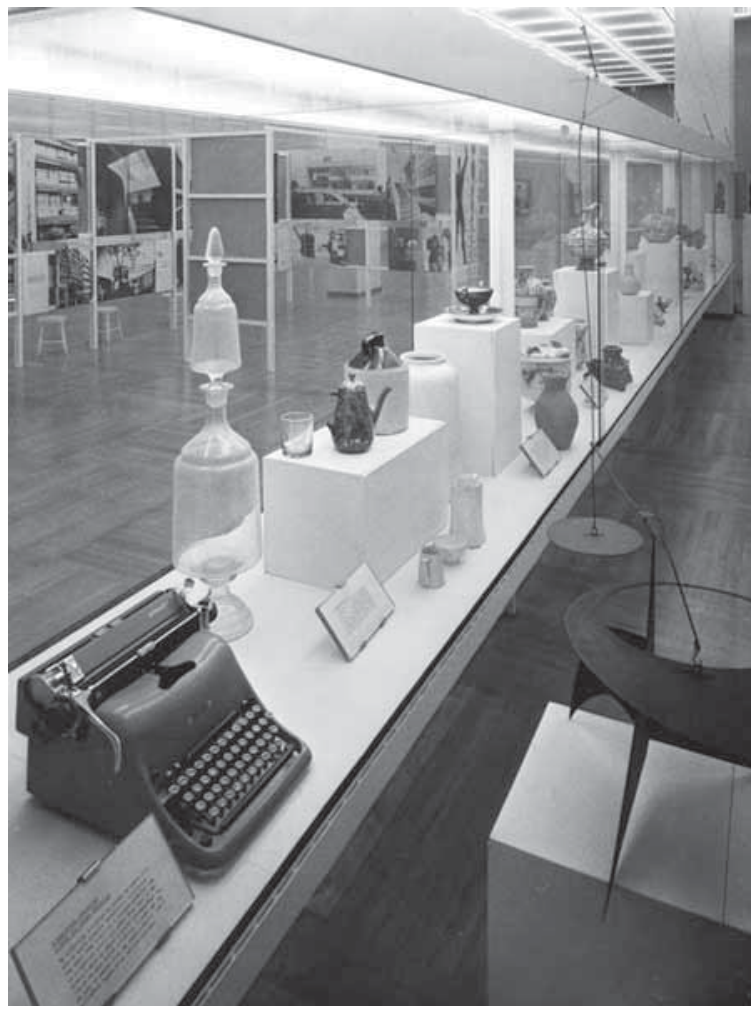

Ambas as propostas expositivas, a Exposiç̃̃o dA CADEIRA VITRINE DAS Formas conciliam objetos de diversos períodos, colocando lado a lado uma poltrona barroca e uma cadeira Eames, ou ainda uma máquina de escrever, contemporânea à época, junto a artefatos de civilizações anteriores como estratégia para evidenciar que o resultado formal dos objetos se dá por uma compreensão do contexto no qual a produção se dá. Não se trata de um discurso de retomada ao artesanato, ao contrário disso, mas de uma compreensão ampliada do processo de produção dos objetos, nos quais é justamente o domínio de técnicas e materiais num determinado recorte de espaço e tempo que configura a própria concepção das formas.

E dentro dessa perspectiva, o discurso proposto pelo Museu tem ainda como premissa a ênfase à pesquisa de uma nova 
linguagem como a resposta mais pertinente às necessidades do homem naquele período. O texto dedicado à Exposição VITRINE DAS FORMAS se encerra como o seguinte trecho:

“(...) Os autênticos criadores de formas em nossos dias são os assim chamados desenhistas industriais os quais (...) cabe encontrar um traço de união entre 0 produto mecânico $e$ as exigências estéticas: sobre eles recai a responsabilidade de educar a visualidade contemporânea dentro de um novo padrão artístico, criando uma forma para os nossos dias que possa competir com o patrimônio do passado." ${ }^{13}$

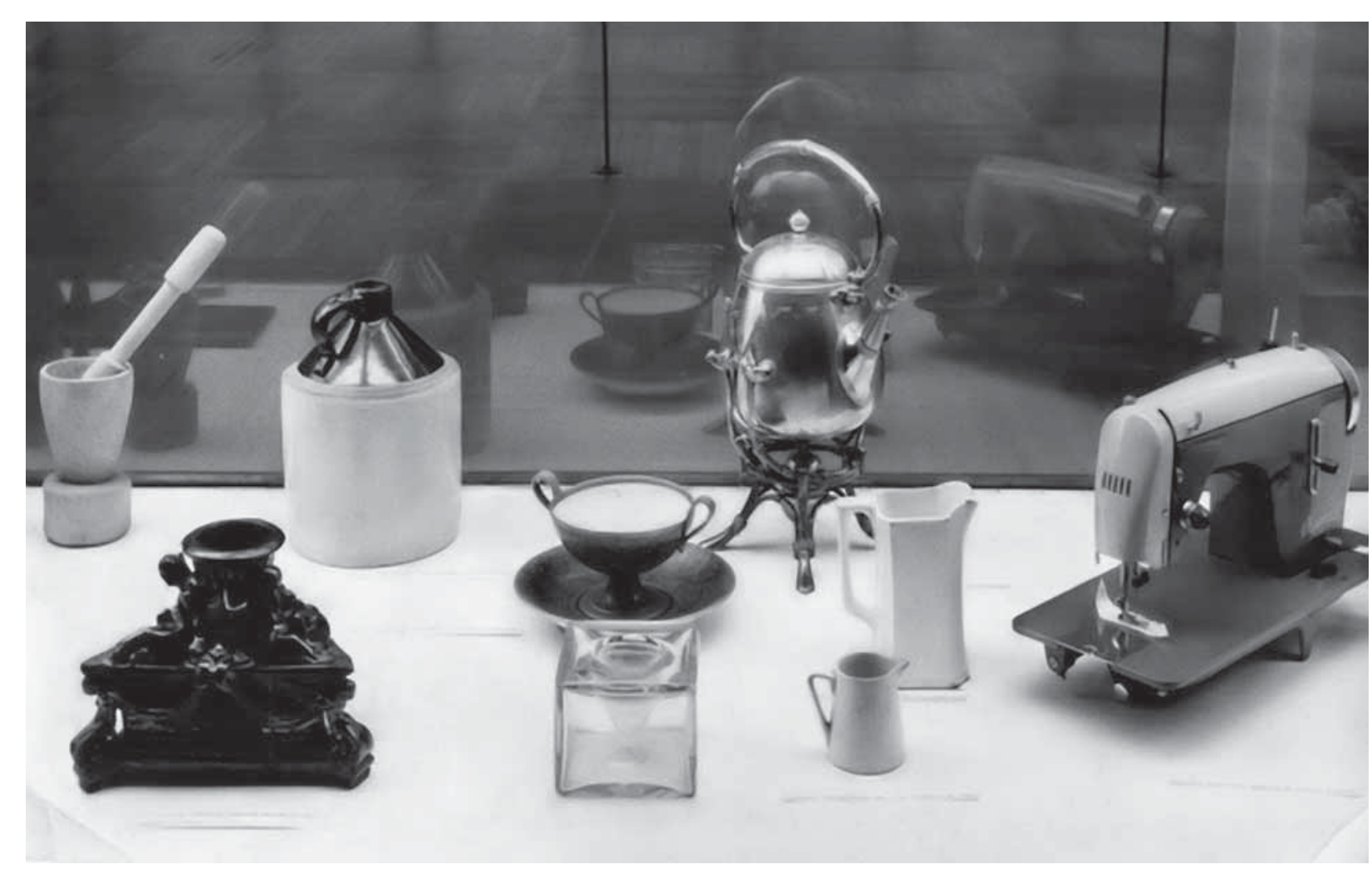

O9 VITRIN DAS Formas 1950 Documentação do MAS

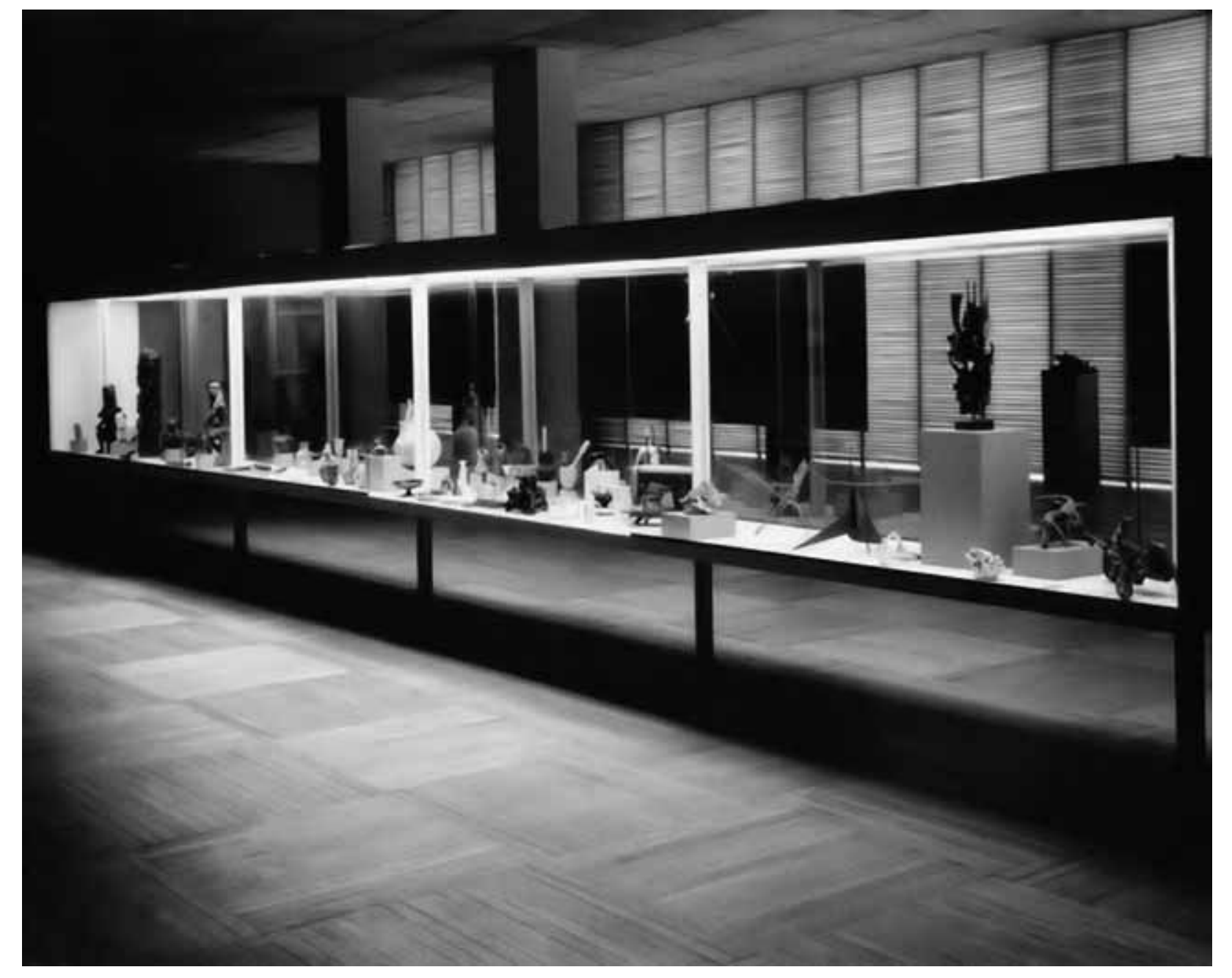

Caberá a uma série de exposições posteriores, sobretudo àquelas após a passagem de Lina Bo Bardi pela Bahia, adicionar novos paradigmas à discussão da adoção de uma linguagem estética como proposta para o desenvolvimento do design no Brasil.

A polêmica em torno das relações entre arte, artesanato e indústria é uma discussão recorrente nos anos 1950 no Brasil e reflexo tardio de um debate iniciado ainda entre os séculos XVIII e XIX, ainda durante o início do período de 10 VItrine das Formas 1950 Documentaçãa do MAS desenvolvimento industrial europeu. E no pós-guerra tal polêmica é assunto de destaque no debate cultural de países em processo de 
transição de uma economia predominantemente agrária para a industrialização acelerada. ${ }^{14}$

Cabe aqui retomar a produção escrita contemporânea às exposições em questão e que revelam essa perspectiva. $\mathrm{O}$ texto Artesanato e indústria publicado na edição número nove da revista Habitat, em 1952, discutido anteriormente em pesquisa de mestrado, colabora para a compreensão das ideias vigentes no período. Vale lembrar que neste período a revista Habitat é também dirigida por P. M. Bardi e Lina Bo Bardi.

"A luta entre 0 artesanato e a produção industrial é uma luta declarada. Iniciou-se, digamos, há uns oitenta anos, e não parece estar prestes a acabar. No plano teórico, o problema da coexistência desses dois sistemas de produção é quase que insolúvel, pois o artesanato é uma indústria anacrônica, insuficiente, e por outro lado a indústria, isto é a produção em série é uma arte completamente nova, ainda em processo de evolução. (...) Existe em toda a parte a mania da peça única, do objeto original, do objeto "artístico": as condições econômicas, porém, fazem-no caro e reservado somente para poucos; e ainda nem sempre apropriado desempenhar a função para o qual foi feito. Existe pois, um so caminho, o mais simples e mais óbvio: produzir esse objeto em série, fazer um produto standard, usando a mesma precisão instrumental e funcional com que a inteligência do artesão fabricava seus produtos que, em parte, ficam na história como exemplos absolutos de civilização." 15

Neste momento, a ênfase ao processo produtivo seriado com forma de atender às demandas atuais reforçará o modelo modernista como a linguagem formal mais adequada às novas condições técnicas e novos materiais. Inicialmente a proposição do discurso a estética moderna como a mais adequada às perspectivas da industrialização parece se insinuar, porém a prevalência do modelo internacional como linguagem estética para o desenvolvimento do design no Brasil se afirmará muito mais por outras inciativas e da própria conjuntura do país do que por uma proposição do Museu. O MASP entende o design como manifestação de arte modernismo é também uma manifestação artística. Porém parece-me que, a defesa sobre a formação de um artista moderno o desenhista industrial - àquele período - se dá no entendimento de um sujeito que domina materiais e técnicas de sua época não necessariamente, na defesa da adoção do vocabulário formal modernista. Ao contrário disso, o Museu será pioneiro em defender a consolidação de uma produção apoiada no conhecimento das tradições técnicas, estéticas e históricas do próprio país como forma de desenvolvimento de uma produção original.

Otexto ARTESANATO E INDÚSTRIA encerra-se com uma proposição:

“(...) A indústria não pode trabalhar com os moldes do artesanato: os resultados dessas experiências foram cópias indecorosas, não correspondendo em geral às exigências de custo e do material. 0 que é preciso é uma escola naciona de desenho industrial, capaz de formar artistas modernos. Modernos no sentido de conhecer materiais, suas propriedades e possibilidades e, portanto, as formas úteis e expressivas que requerem. N ovas ligas metálicas, materiais plásticos, sintéticos, estão paulatinamente substituindo os velhos materiais: madeira, o bronze, o barro." ${ }^{16}$

Àquele momento, o objetivo é, antes de tudo, propor uma perspectiva ampliada do campo da arte, na qual o design é parte e tema de grande importância ao qual o Museu de Arte de São Paulo dedicar-se-á ao longo de várias décadas e, por conseguinte, a tentativa de elaborar um discurso por meio de suas exposições 
que traga à luz a importância do objeto de uso cotidiano, cioso de seus valores técnico, histórico e estético e, portanto, resultados de uma profunda compreensão de inúmeros aspectos de uma sociedade, é uma iniciativa sem precedentes anteriores no País. Lina Bo Bardi e Pietro Maria Bardi são precursores na formação do pensamento sobre design no País. Mais do que isso são fundamentais para a percepção inicial de uma sociedade acerca da importância de seus objetos.

\section{NOTAS}

1. Nesta pesquisa, elege-se o uso do termo design para também referir-se ao campo do desenho industrial, nomenclatura utilizada para identificar a área no Brasil até finais da década de 1970. A questão dos significados contidos na compreensão das nomenclaturas desenho industrial e design foi amplamente discutida pela pesquisadora durante sua pesquisa de mestrado: Do desenho industrial ao design no Brasil: uma bibliografia crítica para a disciplina, apresentada à Pós-graduação da Faculdade de Arquitetura e Urbanismo da Universidade de São Paulo, em 2008.

2. CARA, Milene. Do desenho industrial ao design no Brasil: uma bibliografia crítica para a disciplina. São Paulo: Blucher, 2010. p.33.

In Exposição cronológica do desenvolvimento das formas da cadeira no Museu de Arte. Folha da Noite, 16 de setembro de 1948

4. In Museu de Arte - Exposição da C adeira. Diário de São Paulo, 26 de março de 1948

5. Texto extraído de carta para nota de publicação de G. Borchardt, assistente do museu, à Agência Nacional. O mesmo texto está presente em nota publicada no Diário de São Paulo em 26 de março de 1948.

6. Trecho transcrito de documento pertencente ao acervo histórico do Museu dedicado à explanação das intenções da exposição, de prováve utoria de Pietro Maria Bardi ou Lina Bo Bardi, porém sem identificação do autor.

Idem

Idem 
9. A exposição Arte Popular Pernambucana foi inaugurada no Museu de Arte de São Paulo em 25 de Janeiro de 1949 com o patrocínio da Comissão Nacional de Folclore do Instituto de Educação, Ciência e Cultura - órgão nacional da UNESCO. A exposição apresentou trabalhos de ceramistas do interior pernambucano, entre eles bonecos do mestre Vitalino.

10. Exposição da CADEIRA. Diário de São Paulo, 19 de setembro de 1948

11. Trecho transcrito de documento Vitrine Das formas pertencente ao acervo histórico do Museu dedicado à explanação das intenç̃es da exposição, de provável autoria de Pietro Maria Bardi ou Lina Bo Bardi, porém sem identificação do autor.

12. STOLARSKI, A. Alexandre Wollner e a formação do design moderno no Brasil: depoimentos sobre o design visual brasileiro/ Um projeto de André Stolarski. São Paulo: Cosac Naify, 2005. p. 37.

13. Trecho extraído do documento Vitrine DAS FORMas transcrito do acervo histórico do Museu.

14. CARA, Milene. Do desenho industrial ao design no Brasil: uma bibliografia crítica para a disciplina. São Paulo: Blucher, 2010. p.43.

15. Artesanato e indústria. Habitat (9): 86, 1952

6. ARtesanato e Indústria. Habitat (9): 86, 1952 

dedicada à propaganda, proposição que guarda em si, sobretudo, a defesa de uma concepção de arte inclusiva de outros saberes já ditos "menores".

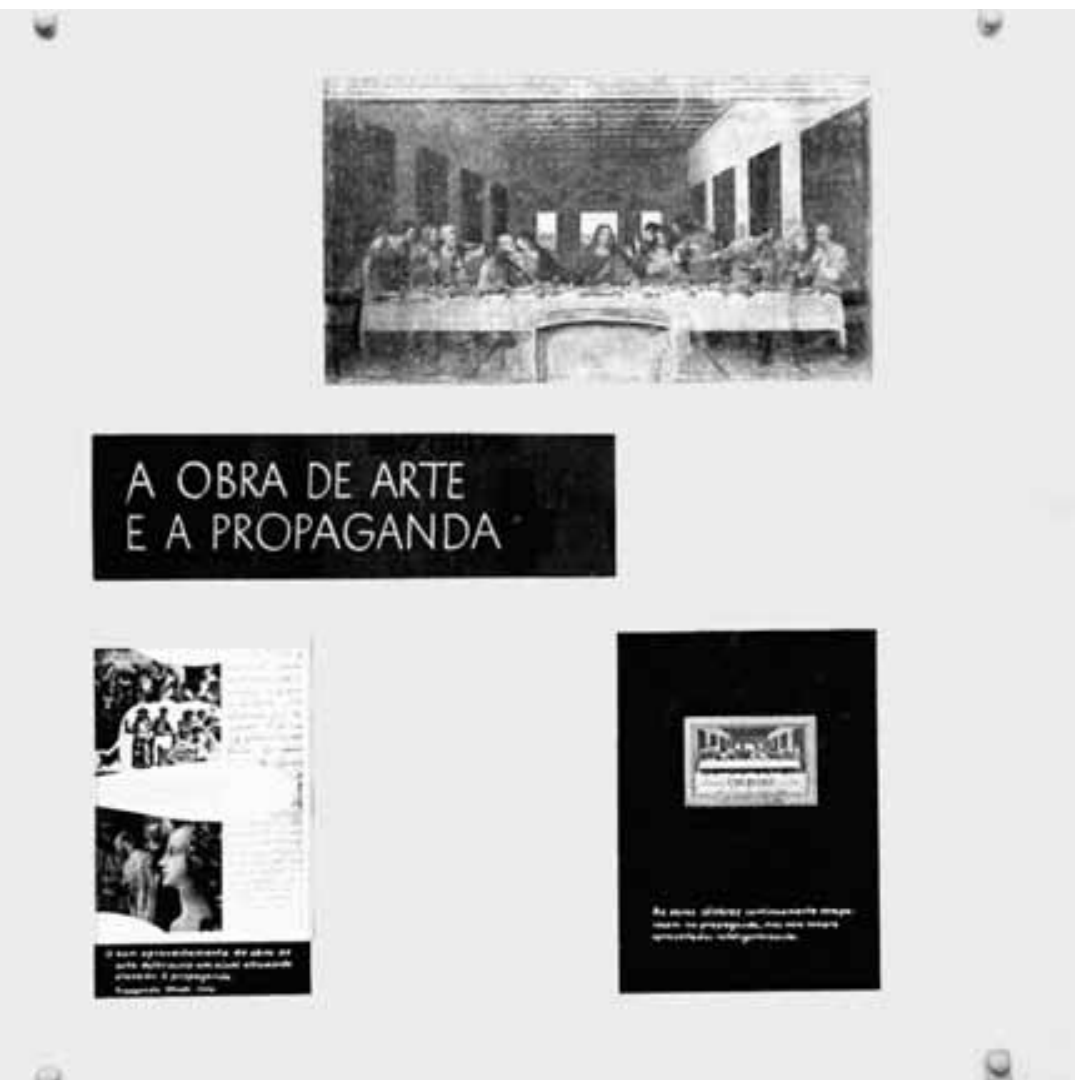

A este primeiro aspecto didático, soma-se outro: a proposta de reflexão sobre as relações entre a produção gráfica e o contexto na qual esta se dá. Contexto, aqui citado e compreendido, como os aspectos técnicos e históricos relativos a um espaço e tempo no qual a produção ocorre. Uma das convicções mais presentes no discurso proposto por meio das exposições é o entendimento do processo de concepção no design como resultante de uma profunda compreensão dos conhecimentos técnicos, históricos, políticos, econômicos, sociais e culturais de uma sociedade circunscrita a um lugar e a um tempo específicos. É esta convicção, creio eu, que traduz da maneira mais adequada o conceito presente em inúmeros textos expositivos: a ideia de uma "moral" do objeto, da produção gráfica ou da moda.

Esta "moral", a meu ver, refere-se a uma coerência da produção às características do seu tempo, isto é, a pertinência às técnicas, materiais e condições histórico-culturais propostas pelo contexto geográfico e temporal nos quais ela se dá. É também este tema uma preocupação da Exposição de ArTES Gráficas DE 1949, do I Salão da Propaganda e, mais tarde retomado reiterado, na exposição História DA Tipografia, realizada em 1979, no Museu.

A originalidade das propostas expositivas, aqui discutidas, vai ainda além das já descritas anteriormente, dedicadas ao discurso do objeto de uso ordinário. No campo gráfico, ambas as iniciativas, tanto de 1949, quanto de 1950, não se limitam à exibição restrita à sala de exposições do Museu, à contemplação das peças. Propõem ainda atividades de debate e participação efetiva do público, por meio de inúmeras palestras, exibições de filmes, visitas a fábricas e oficinas práticas propostas no espaço do Museu.

A efervescência das atividades em torno das exposições antecipa as intenções didáticas da instituição: o desejo de formar profissionais atuantes no campo do design gráfico, que culminará com a criação do IAC MASP no ano seguinte, responsável pela formação da primeira geração de designers modernos brasileiros. As atividades propostas pelo Museu, bem como as exposições, não somente reforçarão o caráter inovador da instituição, uma vez que ao trazer para si tais debates rediscute e propõe uma compreensão singular do papel dos museus junto à sociedade, bem como o tornará um dos mais importantes pólos de reflexão em torno da arte, ditas à época, maiores e menores. 


\section{A EXPOSIÇÃO DIDÁTICA \\ DE ARTES GRÁFICAS}

Com a intenção de criar uma seção dedicada às artes gráficas e, em particular, o livro, da mesma forma como foi proposta no ano seguinte, 1950, a exposição VItrine DAS Formas, uma seção permanente é dedicada à discussão do objeto de uso; é, também, proposta a Exposição Didática de Artes Gráficas, apresentada imediatamente após o fechamento das Exposições DiDÁTICAS dedicadas às artes plásticas, e cuja intenção, após sua exibição era inaugurar uma sala dedicada ao tema com exposições fixas e periódicas.

O Museu, com a continuidade de propostas expositivas de caráter didático, além de inaugurar uma nova perspectiva sobre o pape do próprio museu junto à sociedade, traz consigo uma iniciativa completamente original, reiterada a cada uma das exposições ditas "didáticas": a visão singular do campo da arte, que inclui manifestações, além das dedicadas às artes plásticas, de arquitetura, design de objetos, gráfico, de moda e da cultura material do País.

"A série de exposições didáticas que o Museu de Arte programou com o objetivo de oferecer ao público paulistano, elementos para uma compreensão global das artes plásticas, vem alcançando os mais auspiciosos resultados. A primeira dessas mostras ofereceu, num conjunto de oitenta e quatro painéis, a história do desenvolvimento das artes-plásticas, desde a pré-história até nossos dias. N essa mostra foram analisados os principais períodos da história da arte, incluindo noções de história geral, ao lado das manifestações no campo da arquitetura, pintura, escultura e artes menores que correspondessem aos fatos históricos abordados. Foi essa exposição, graças ao critério absolutamente didático e simples com que foi apresentada, motivo da mais ampla aceitação. Basta lembrar 0 interesse demonstrado, durante sua estada em São Paulo, pelo Sr. René Huyque, conservador-chefe do Museu do Louvre, que se manifestou favoravelmente à organização de mostras idênticas nos museus europeus. Também a revista "Museum" da UNESCO, no seu último número, dedicado a "museus e educação", aponta a iniciativa paulista como um dos exemplos mais felizes da compreensão moderna da função dos museus. (...)

Prepara o Museu de Arte, atualmente, uma nova exposição que figurará nos painéis da seção didática: trata-se de mostra histórica do desenvolvimento das artes gráficas. Será organizada através da colabo ração do D epartamento de Pesquisas emA rtes Gráficas e do conhecido bibliófilo Sr. Ernani Seabra. Inúmero material ilustrativo, gráficos, explicações etc. serão oferecidos aos frequentadores do Museu de Arte, para que tenham uma ideia de conjunto, precisa, do desenvolvimento dessa arte que ocupa, no mundo moderno, papel relevante no desenvolvimento da cultura. Paralelamente à mostra, será também exibido valioso material original de artes gráficas, oferecidos, a título de empréstimo por particulares." 2

E é justamente por meio da exibição de documentos antigos ros, como fragmentos de papiros, pergaminhos manuscritos, omados a painéis didáticos com sequências históricas da evolução da técnica e dos processos empregados na execução das artes gráficas, que a Exposição Didética de ArTes Gráficas teve como objetivo possibilitar a compreensão dos trabalhos que são realizados na confecção de livros, impressos, jornais e outro serviços gráficos. Além da exposição, foram propostas exibições de filmes sobre artes gráficas, palestras, conferências, aulas no Museu e visitas às indústrias gráficas. Na mesma ocasião foi lançada a revista 
Brasil Gráfica, primeira revista sobre artes gráficas da Editora Brasil Gráfico Ltda. e a promoção de um seminário de biblioteconomia pelo Instituto de Administração da Universidade de São Paulo a se realizado no auditório do Museu, seminário que, todavia, embora citado, não aparece descrito em fontes seguras que ofereçam informações sobre o acontecimento efetivo do evento.

"Será apresentada brevemente no Museu de Arte de São Paulo uma interessante exposição Didática de Artes Gráficas. N essa ocasião teremos a oportunidade de apreciar um estudo completo de toda a evolução histórica das artes gráficas, desde as primeiras formas de escrita até os mais modernos impressos, com suas composições perfeitamente harmoniosas, belos tipos e cores brilhantes. 0 material recolhido para ser exposto, pode-se dizer nunca antes ter sido apresentado ao público. Serão vistos fragmentos de papiro com inscrições hieroglíficas, inúmeros pergaminhos, manuscritos originais, incunábulos, impressos antigos de todos os séculos, e ainda livros raros, verdadeiras preciosidades bibliográficas e muitas outras curiosidades tipográficas. Ao mesmo tempo, em 84 pranchas didáticas, apresentar-se-á um resumo da evolução da técnica e do maquinário gráfico. Será fácil, dessa forma, a compreensão nítida dos intrincados processos de trabalho realizados nas artes gráficas. Veremos, por fim, uma comparação entre o bom e o mau impresso, na qual se salientam certos defeitos da má tipografia, entre outros 0 inadequado uso de tipos e a desar monia de co res, defeitos esses que passam desapercebidos em razão de um inveterado hábito de mau gosto." 3

A iniciativa, ao ir além das salas expositivas do Museu, propondo a exibição de uma série de filmes técnicos sobre o assunto, cujos títulos eram: "Como se faz uma boa impressão", "Os tipos falam" a "História do Papel" 4 , além de aulas, conferências e a organização de grupos para a visita em indústrias gráficas, cuja ideia era conhecer in loco os processos produtivos gráficos, acentua e amplia o caráter didático da mostra na medida em que o discurso não se limita somente a esboçar uma nova perspectiva para o campo da arte, ou ainda somente evidenciar o caráter histórico e os processos produtivos no campo da gráfica, mas antecipar a intenção de formar profissionais para o fértil campo de trabalho gráfico em ascensão no País àquele período. É possível considerar essas atividades somadas ao I Salão Nacional da Propaganda como iniciativas precursoras da criação do IAC MASP, responsável pela formação dos primeiros designers modernos no Brasil.

"Ainda nesta ocasião será inaugurada a Seção do Livro e de Artes Gráficas no Museu de Arte. Pretende-se criar nessa Seção um curso de Artes Gráficas, onde se ensinară os fundamentos artísticos, o aperfeiçoamento dos métodos principais, ateo ria de ar tes gráficas e noções de ar te complementares. Será instalada uma pequena oficina de composição manual, de impressão e de encadernação artística." 5 


\section{O I Salão Nacional da PROPAGANDA}

Dentre as iniciativas expositivas às quais este texto se dedica uma das mais significativas e surpreendentes foi o I SALÃO Nacional da Propaganda, inaugurado no final do ano de 1950. Nas palavras de Chico Homem de Melo, é surpreendente o fato de um museu de arte promover uma exposição de propaganda surpreendente a transformação de um convite em cartaz; e é também surpreendente a contundência da linguagem gráfica adotada por Danilo Di Prete. Mais uma vez o MASP reforçaria a sua imagem como instituição inovadora, empenhada em oxigenar o ambiente cultural brasileiro da época. ${ }^{6}$

E são as já citadas palavras de Bardi na inauguração do evento,

"dividir a arte, numa maior e noutra menor, é um ponto de vista que carece de sentido",

citadas na abertura deste ensaio que mais uma vez corroboram para a postura original do Museu na abordagem do campo da arte por conseguinte, do campo do design.

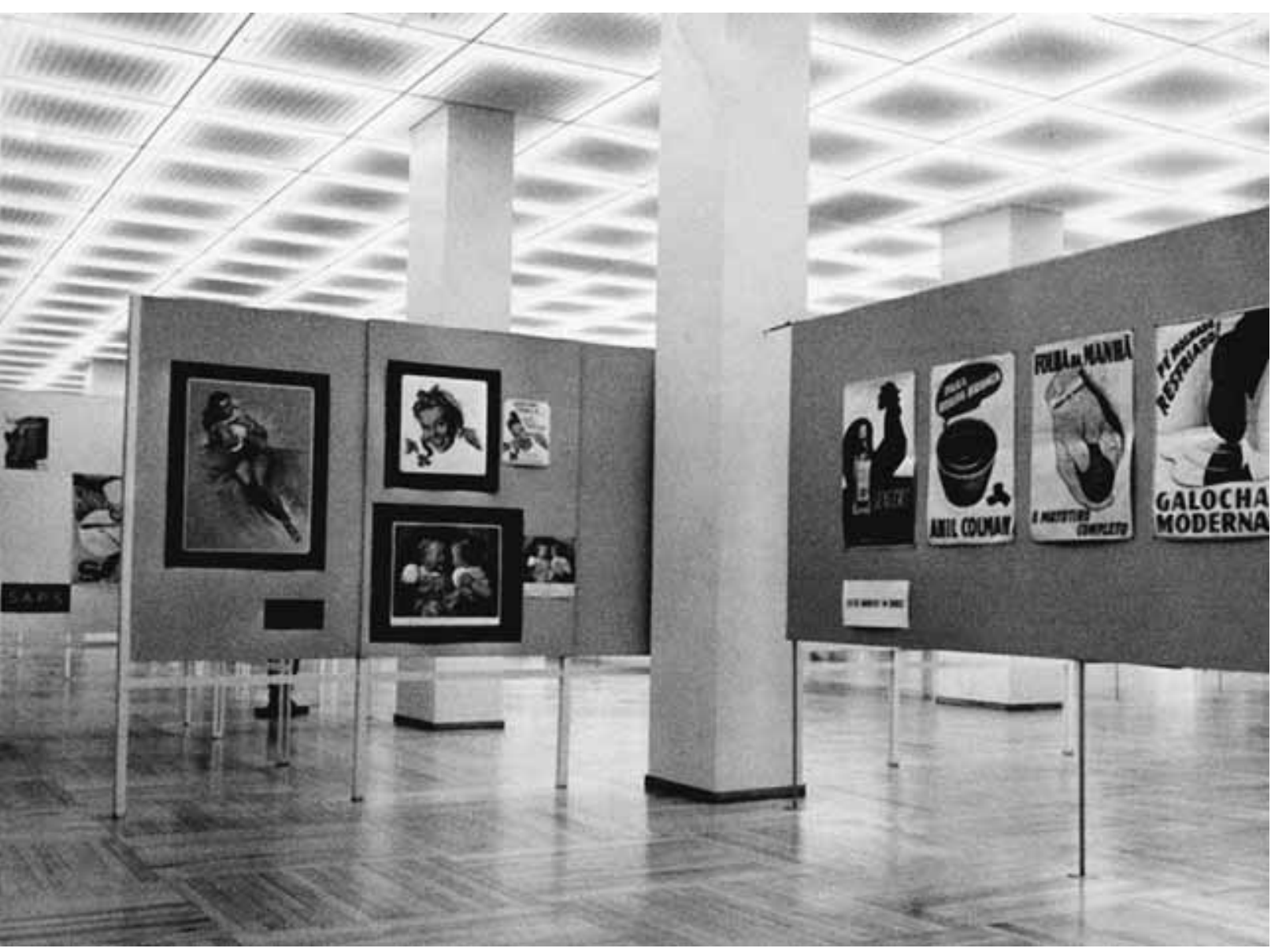

Organizada por Pietro Maria Bardi e Lina Bo Bardi, com apoio da Associação Paulista de Propaganda e também de Geraldo Wilda da Mac Can, entre outros, a exposição teve como objetivo apresentar o desenvolvimento da propaganda em outros países e no Brasil, além de debater o papel do publicitário no exercício da criação, da publicidade como meio de arte visual. A discussão acerca da propaganda é de fundamental relevância na medida em que a política desenvolvimentista brasileira tem como lema o famoso "cinquenta anos em cinco", com ênfase à industrialização acelerada o surgimento da TV Tupi é também um dos símbolos de uma época. A TV, de propriedade das Emissoras e Diários Associados de Assis Chateaubriand, é a primeira emissora a entrar em funcionamento 
em 1950 e é, inclusive, no MASP que se concentram os evento em torno da transmissão do primeiro sinal da TV. Neste momento, é significativo o crescimento dos suportes em que o designer e o publicitário são chamados a colaborar: jornais, revistas, livros, capas de disco.

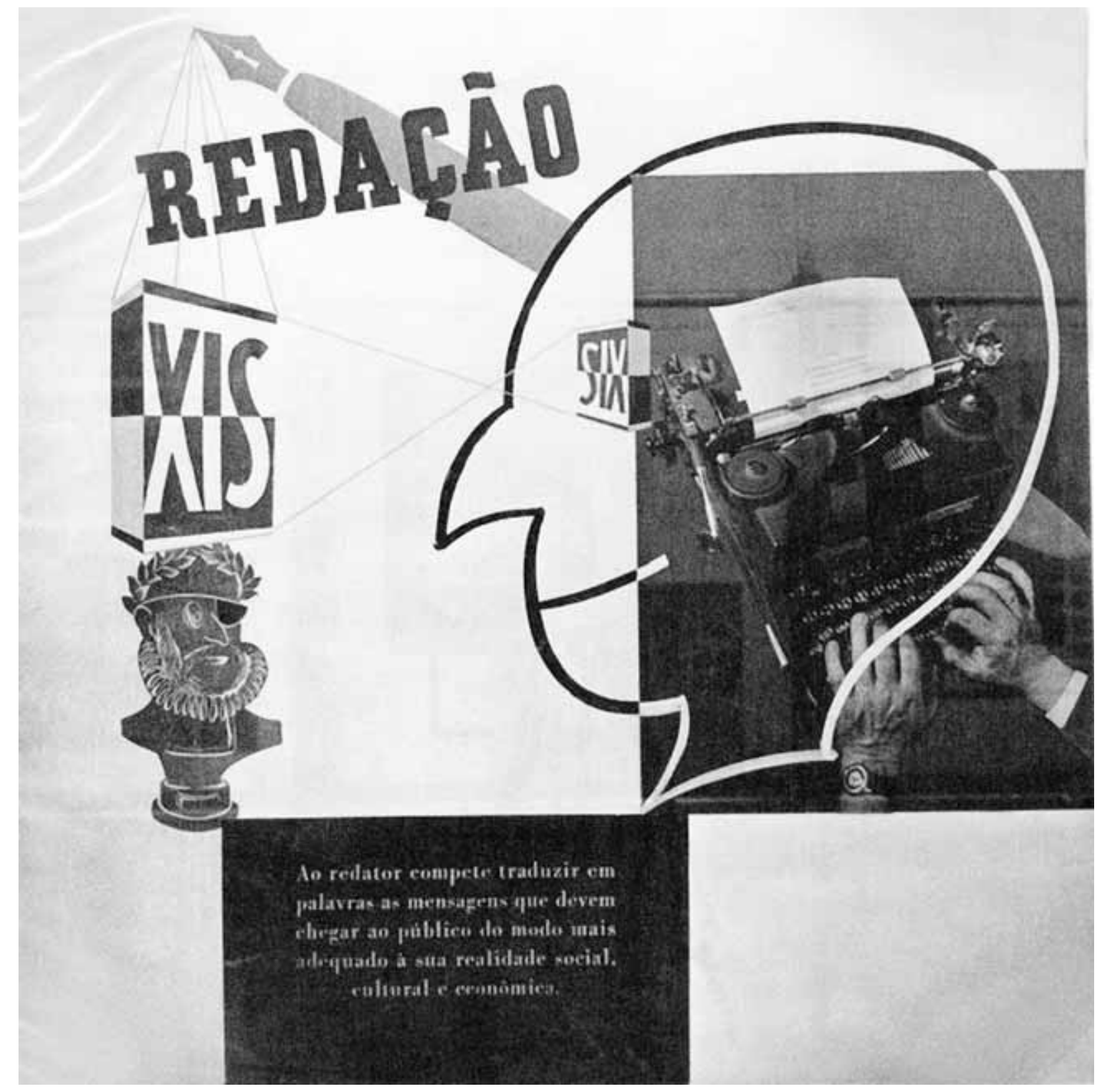

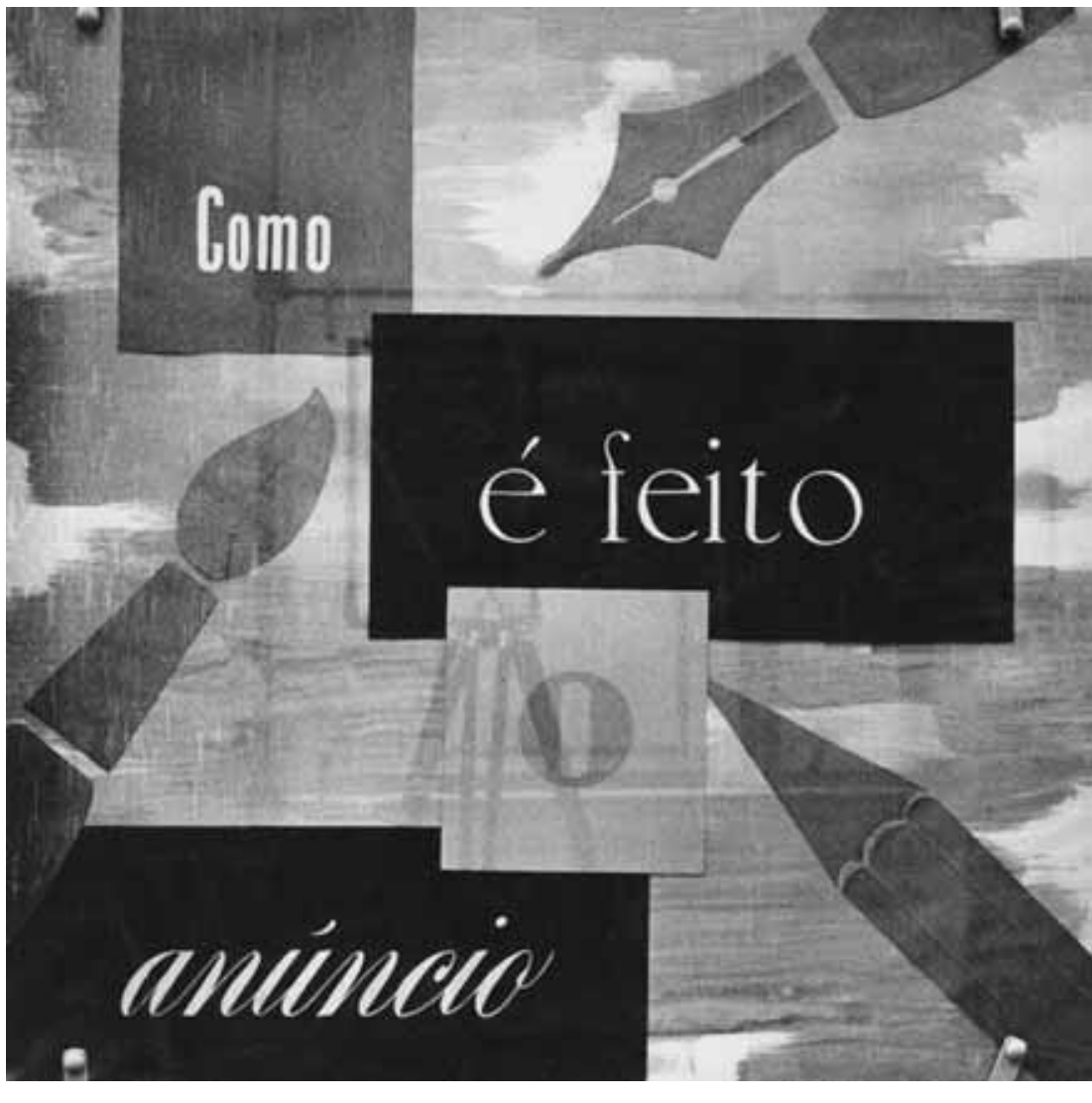

A exposição foi dividida em três partes: a primeira históricodidática, com uma retrospectiva da história e do desenvolvimento da propaganda; a segunda dedicada à representação das agência com a exibição das peças contemporâneas e a terceira, dedicada à representação dos artistas. Nesta última, foi exibida uma rara coleção de cartazes de Toulouse-Lautrec e litografias de Cheret cedidas pela galeria nova-iorquina Knoedler, como uma tentativa de aproximar a compreensão da atividade da propaganda às artes visuais e ainda, foram também exibidos originais de 1851 , 14. 1ㅇ Saläo da Propaganda 1950 Biblioteca e Centro de
Documentaçăo do MAS realizados por ocasião da Exposição Internacional de Londres raros catálogos industriais; cartazes de teatros do século passado e anúncios realizados na Europa nos últimos cinquenta anos. 
"Inicialmente devemos sublinhar a importância internacional da primeira "mostra da propaganda"; depois, louvar a direção do Museu de Arte, por ter organizado esta exibição.

0 público de São Paulo terá a oportunidade de entrar em contato, a partir de hoje, com uma exposição de cartazes, anúncios de propaganda, pacientemente reunidos pela direção do Museu de Arte, a fim de mostrar, orientar àqueles que se interessam pelo preparo do anúncio, de um cartaz. Esta exposição, que tem o patrocínio daAssociação Paulista de Propaganda, já muito se recomenda.

Foi escolhida a data que assinala o "Dia da Propaganda" para a inauguração do certame. Será a exposição dividida em três partes: 1) didática; 2) representação das agências; 3) representação dos artistas.

A parte didática mostra, com absoluta segurança, como se faz um anúncio graficamente anunciado. A da representação das agências constitui, no espaço que o Museu Ihes reservou uma oportunidade para que mostrem o que de eficiente tem produzido do ponto-de-vista artístico e de propaganda propriamente dita.A seção reservada aos artistas é, sem dúvida, uma das mais interessantes. Aí terão os nossos desenhistas, o público e até mesmo as agências de propaganda, a rara ocasião de admirar uma série de cartazes de Toulouse-Lautrec. Acentuamos em nota para o "Diário de São Paulo", que 0 desenho está ligado à crônica cotidiana: ilustra o drama, a comédia e a sátira. Um pintor houve que compreendeu muito bem isso. Seus desenhos são puros, traços firmes semar rependimento.N os contornosexatos,àsvezesexagerados, muito sabemos dos modelos. São feitos à carvão, bico de pena, sanguínea e alguns coloridos.
Se fôssemos classificá-los por um lado da sua obra tomaríamos, então, os seus desenhos, como exemplos convincentes do espírito de observação desse pintor. Foi ele o primeiro a introduzir desenhos artísticos nos programas de teatro, em cartazes, menus, capas de livros e ilustrações nos jornais.

Em todos os seus desenhos, esse pintor nos mostra a sua força de interpretação quase milagrosa: no contorno seguro acentua-se a vibração da linha sensível. Qualque desenho, ao lado dos seus, cheios de paixão, parece inanimado. Porque os seus recursos técnicos foram até a graça pura de uma cabeça de criança.

Pois é deste Henri Toulouse-Lautrec e de outros, que a direção do Museu de Arte, cuidadosamente reuniu para esta exibição de uma verdadeira arte da propaganda. Os nossos artistas encontrarão ali preciosas sugestões." 8 
A escolha da obra de Toulouse-Lautrec para figurar entre os temas da exposição evidencia o discurso proposto de compreensão da propaganda como uma expressão de arte visual. Mais do que isso, também reforça a concepção de uma arte atrelada às técnicas, à história, ou seja, a todas as condicionantes de espaço e tempo na qual ela se insere.

Porém o debate vai além, a exposição mobilizou uma ampla discussão na sociedade paulistana, na medida em que são muito os textos dedicados às ideias propostas durante a mostra. Além da mostra, foram proferidas as palestras: "Propaganda e insatisfação humana" por Rodolfo Lima Matersen; "São Paulo de 1860, vista através dos anúncios da época" de Orígenes Lessa; "Um programa de rádio" por João Carilo; "Função educacional da propaganda" por João Alfredo de Sousa Ramos; "Como se faz radiofonização" de Oswaldo Moles; a "Função Social da Propaganda" por João Doria e "Aspectos pitorescos da propaganda" de Godoy Prado. Além das palestras, foram exibidos filmes durante a mostra. É possível localizar em textos publicados em jornais, trechos das palestras proferidas que nos aproximam do debate à época.

"De todas as definições e conceitos que conheço sobre propaganda - gravei o que foi dado pelo genial e irreverente que se chamou Bernard Shaw. Pediram-Ihe, um dia, que dissesse que definisse 0 que era propaganda. 0 famoso irlandês não teve dúvidas e respondeu: “Propaganda é aquela coisa que faz a gente comprar o que não precisa com o dinheiro que não tem!" C omo veem, está aí uma aspecto pito resco da propaganda. Através de um paradoxo, aparentemente inconsequente, Bernard Shaw disse algo que nos faz pensar na universalidade dessa arte e, como consequência, volvemos nossa atenção para a propaganda brasileira. (...) Pouca gente sabe que a profissão de "publicitário", surgida, por assim dizer, pelas contingências da vida, nos princípios deste século, possui uma história fascinante rica de episódios pitorescos, vivida com aquela verve que os nossos prosadores, poetas e jornalistas sabiam emprestar às coisas de então.(...)"

Godoy Prado prossegue citando personagens eminentes da história brasileira no papel de publicitários e ainda sobre o desenvolvimento da propaganda através dos tempos, da Antiguidade ao presente. Outra contribuição singular são as considerações acerca do papel social da propaganda no Brasil, para o qual João Alfredo de Sousa Ramos chama a atenção em sua conferência e, antecipa ideia do ensino à distância, ao defender o uso dos novos meios de comunicação como recursos excepcionais para o incremento do sistema educacional brasileiro.

A muitos estudiosos das coisas educacionais passou desapercebida essa função educacional, ou pelo menos não a levaram na devida conta. É que ainda estamos imbuídos, uns mais, outros menos, daquele velho espírito de considerar a propaganda uma literatura de caráter secundário ou acessório. lá se foi esse tempo. A propaganda é instrução, é literatura de primeira plana.

Peque-se qualquer dos grandes jornais, do nosso ou de outros países: veremos a franca sobrepujança da parte da propaganda sobre a parte editorial. O bservemos agora que todas as compras e vendas dos tempos modernos são feitas através dos anúncios; consideremos que todos os conhecimentos de utilitarismo imediato são transmitidos por esta ou aquela forma de publicidade e chegaremos à conclusão irrefutáve de que a parte mais lida do jornal, já pelo seu volume, já pela sua finalidade, é de fato a propaganda.

O s homens públicos deveriam olhar melhor para a finalidade da propaganda empregada como arma de divulgação e educação. 
Os homens públicos só se lembram da propaganda, para a divulgação de suas virtudes de homens políticos. No entanto, - nosso país, dada a sua grandeza territorial, apresenta todos os problemas de educação, higiene e transporte, ainda não resolvidos, constituindo a propaganda, a chave-mestra para sua mais rápida solução.

Cada um desses problemas é maior, em versão econômica, do que, talvez, a renda atual do próprio país, em dez anos Mas poderiam os homens públicos procurar uma forma das mais simples, nos homens de propaganda, uma solução por partes, aproveitando, por exemplo, a divulgação pelo rádio e pela imprensa, a divulgação de uma forma didática Escolas feitas pelo rádio, formando núcleos em fazendas distantes, em lugares onde não é possível se manter uma escola mas onde a boa vontade daqueles que precisam aprender tivesse uma recompensa.

Divulgação e ensino dos problemas da lavoura, o melhor aproveitamento das terras; divulgação e ensino dos problemas de higiene, na defesa deste ou daquele campo de moléstias; da terapêutica desta ou daquela enfermidade, da orientação do s pecuaristas. Por exemplo, na defesa da peste dos porcos." 10

A Exposição Didática de Artes Gráficas e do i Salão ACIONAL DA Propaganda são exposições que não somente esboçam o conceito de arte defendido pelo Museu, como também antecipam, com suas atividades de palestras, exibição de filmes, visitas e aulas propostas, o interesse da instituição na formação de profissionais, que culminará na criação do IAC no ano de 1951. Ambas ainda reiteram por meio da ênfase a uma abordagem histórica, a conviç̧ão de que o processo criativo é resultante de uma ampla compreensão das técnicas, dos materiais e da cultura de uma determinada sociedade circunscrita numa época.
E este último aspecto será recorrente nas exposições dedicadas ao design gráfico, como por exemplo, na Exposição HistóRIA DA TIPOGRAFIA, proposta pelo Museu em 1979, também de caráter didático-histórica; vale ainda dizer que é a partir da reunião de um vastíssimo material: capas de livros, famílias tipográficas, reproduções de vinhetas, anúncios e livros e do lançamento de um livro-catálogo da História da Tipografia no Brasil, na ocasião, que o Museu retomará a reflexão sobre as relações entre a expressão escrita, a gráfica e a política no contexto brasileiro ${ }^{11}$ como forma de evidenciar, não somente a complexidade do desenvolvimento dos processos de impressão no País, como também a complexidade do design e de suas relações com a própria história brasileira. 


\section{NOTAS}

1. In Propaganda da Propaganda. Diário de São Paulo, 05 de dezembro de 1950.

2. No Museu de Arte - Próxima Exposição Didática da História DAS Artes Gráficas. Diário da Noite, 25 de junho de 1949.

3. Trecho extraído de documento em papel timbrado do Departamento de Pesquisas em Artes Gráficas (DPAG) pertencente ao acervo histórico do Museu cujo título é Exposição Didática de Artes Gráficas no Museu de ArTe de São Paulo.

4. Idem.

5. Idem.

6. MELO/COIMBRA. Chico Homem de/Elaine Ramos. (Orgs.). Linha do tempo do design gráfico no Brasil. São Paulo: Cosac Naify, 2011. p.262.

7. In Propaganda da Propaganda. Diário de São Paulo, 05 de dezembro de 1950.

B. SILVA, Quirino da. $1^{\mathrm{a}}$ Exposição da Propaganda. Diário da noite, 04 de dezembro de 1950.

9. Palavras de Godoy Prado, à época publicitário e presidente da Associação Paulista de Propaganda. In: Aspectos Pitorescos DA Propaganda. Folha da Manhã, 07 de janeiro de 1951.

10. Função Educacional da Propaganda. Folha da Manhã, 24 de dezembro de 1950.

11. KLINTOWITZ/PINTO. Jacob/ Zélio Alves. A Censura chegou ANTES DA TIPOGRAFIA. Isto é, 4 de abril de 1979 
Se na época o interesse do Museu em abrigar o I SALÃo NACIONAL DA Propaganda no final do ano de 1950 é surpreendente, o que é possível dizer sobre a ideia de apresentar um desfile de costumes antigos originais conjuntamente com os último modelos lançados em Paris? O espetáculo proposto pelo MASP ao público paulistano foi um empreendimento inédito no País e também em muitos outros.

O espetáculo, nomeado de O Primeiro Desfile de Costumes Antigos e Modernos, também reconhecido como Desfile Dior, ocorre com grande repercussão, em 27 de abril de 1951, em uma passarela montada nas instalações do Museu à Rua 7 de Abril reunindo a elite paulistana. Entre os presentes estavam: a Sra. Renata da Silva Prado, os casais Jorge da Silva Prado, Ademar de Barros, Felix Kowarick, André Matarazzo; as Sras. Vera Alves Lima, viúva Basílio Jafet, Zita Cintra Godinho, Maria Penteado, Maria Kareska, Araci Pereira Lopes, Loli Sousa Dantas, Stela Viana, Camila Cardoso, Odete Matarazzo, Lucilia Veloso, Maria Helena Cunha Bueno e

17 10 D ESFLLE DE C OSTUMES AntIG0S E Modernos / DesfHe DIOR 1951 Documentação do MASP
Gonçalves de Carvalho, entre outros. ${ }^{1} \mathrm{E}$ o mesmo desfile, após sua realização em São Paulo, foi apresentado no Copacabana Palace, no Rio de Janeiro, sob o patrocínio do Museu. 


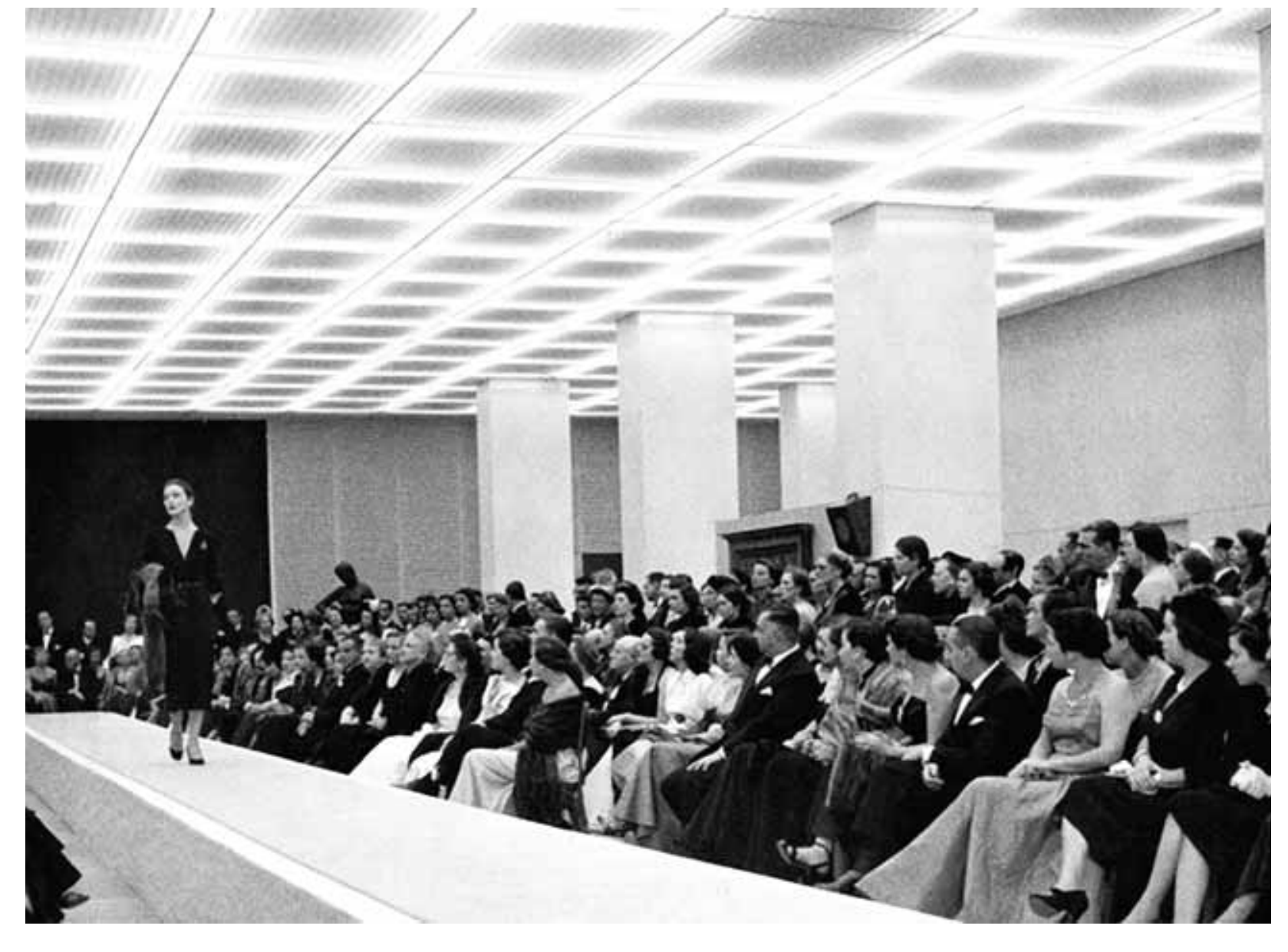

18 10 Desflle de Co Stumes Antigos E Modern OS / DesFlLE D IOR 1951 Biblioteca e Centro de
Documentação do MASP

19 10 D ESFLL De Costumes Antigos E Modernos / D EsFle D Ior 1951 Biblioteca e Centro de
Documentaçăo do MASP

20 10 D esFlLe de Costumes Antigos 2010 Desfle de COSTUMESAnTIGoS
E Modernos / DesFlL DIor 1951 Biblioteca e Centro de Documentação do MASP
Esta iniciativa guardava em si, bem como as exposições citadas nos ensaios anteriores, o desejo de enfatizar uma ampla visão do campo da arte; desejo corroborado, mais uma vez, pelo título da série de exposições: Artes Industriais, da qual este desfile também fez parte. Moda como arte é o que se pretende aqui reforçar. Defende-se a ideia de que a eleição da vestimenta não é um gesto gratuito, mas deve ser acompanhada de um juízo crítico informado. Nesta perspectiva, o Museu propõe um desfile que se inicia com a apresentação de costumes antigos, dos séculos XVIII e XIX, obtidos por meio de empréstimos ou adquiridos em coleções europeias, com as mesmas intenções didáticas já evidenciadas em outras exposições que a precederam, como na Exposição
DA Cadeira ou ainda na Exposição de ArTes Gráficas. Nestas últimas, reforçava-se novamente a ideia do objeto, da gráfica como arte e suas manifestações como resultantes das condicionantes técnicas, estéticas e históricas de contextos temporais e espaciais específicos. Aqui, neste desfile, intenta-se a mesma ideia. Desde a escolha das posições dos modelos para as fotografias, localizadas no acervo histórico do Museu, a ideia de uma compreensão mais abrangente para o campo da arte é anunciada: os costumes são fotografados ao lado de esculturas, pinturas do acervo do Museu, numa atitude de propor a aproximação dos saberes da moda às artes plásticas.
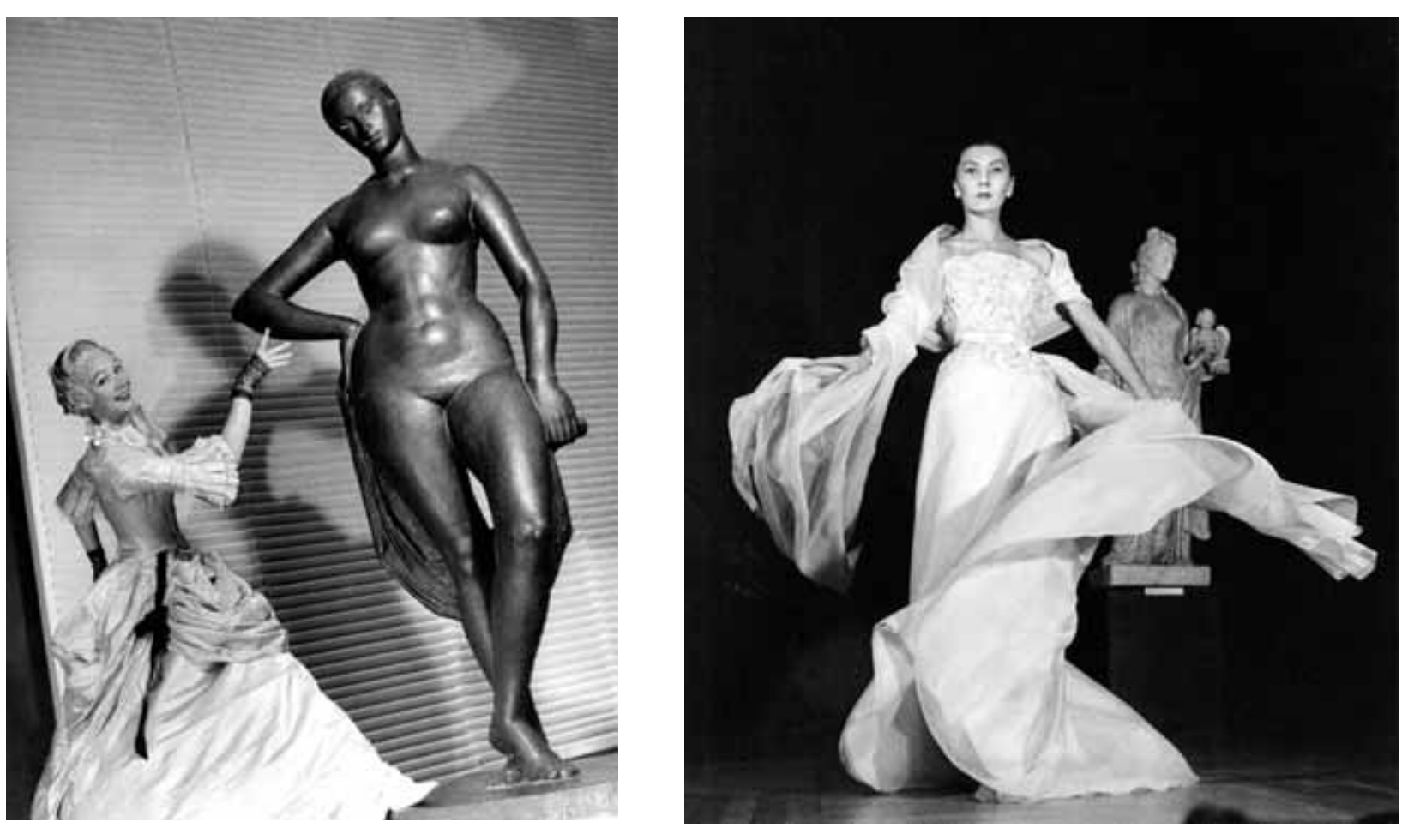
O desfile prossegue com a apresentação de costumes de Christian Dior, costureiro francês, que em 1951, é o nome mais importante da alta costura internacional. A escolha de Dior também não é gratuita. O reinado de Dior iniciara-se em 1947 e é ele quem estabelecera um dos marcos mais importante para o desenvolvimento da indumentária no século XX. Dior marca a transição de duas etapas no processo da moda: o início da passagem de um modelo de produção completamente artesanal da alta costura, para um modelo de empresa moderna no setor. Nos anos 1950, a maison Dior respondia sozinha pela metade das exportações de alta-costura para os Estados Unidos; em 1947, havia apresentado sua primeira coleção na maison, com enorme sucesso, financiada pelo magnata dos tecidos, Marcel Boussac; no final do mesmo ano, inaugurava uma filial de perfumes. Depois, abriria em Nova York uma maison para vender o pret-à-porter de luxo. Em 1949, Christian Dior assina os dois primeiros contratos de licença - meias e gravatas - com sociedades americanas. No ano seguinte, 1950, vê a criação de uma sociedade responsável pelo comércio por atacado e da difusão dos acessórios assinados pela maison. A partir daí, surgiriam uma filia em Londres, uma butique na avenida Montaigne, Paris, licenças para negociar lingeries e a implantação de sucursais em Caracas na Venezuela, na Austrália, no Chile, no México e em Cuba.

Dior representa àquele momento para a moda e, portanto para o campo do design, justamente a superação de um modelo de negócio predominantemente artesanal para uma lógica de escala. A maison apoiava-se nos saberes e técnicas da alta-costura francesa artesanal para construir uma empresa cuja lógica era também a da escala associada à identificação do produto por meio da imagem. Ao mesmo tempo em que se confeccionavam costumes com alto valor agregado, nobres tecidos e a dedicação de inúmeras horas de trabalhos manuais - restritos a um público específico - é a partir das inúmeras licenças e do pret-à-porter que Dior teria sua marca e o capital simbólico dela atrelado a produtos com custo menor e sobretudo, mais acessíveis a um público consumidor maior. Dior, com isso, cria coleções que incluem saberes e técnicas tradicionais francesas, conciliando costumes altamente sofisticados do ponto de vista da produção a roupas mais acessíveis, porém de luxo, ao consumo do mercado americano em ascensão no pós Guerra. E é justamente a compreensão de Dior dos novos paradigmas d sociedade moderna, industrial e ávida pelo consumo em escala que garantirá um amplo mercado à empresa, permitindo o crescimento da maison em escala internacional. No ano seguinte, em 1952, inspirada pela experiência da maison Dior, Lina Bo Bardi proporia, ousadamente, o $1^{\circ}$ Desfile de Moda Brasileira, como tentativa de projetar, em âmbito nacional e internacional, a criação de uma moda brasileira.

21 10 D EsflLe de C O Stumes Antigos E Modern os / D ESFLE D IOR 1951 Documentação do MAS

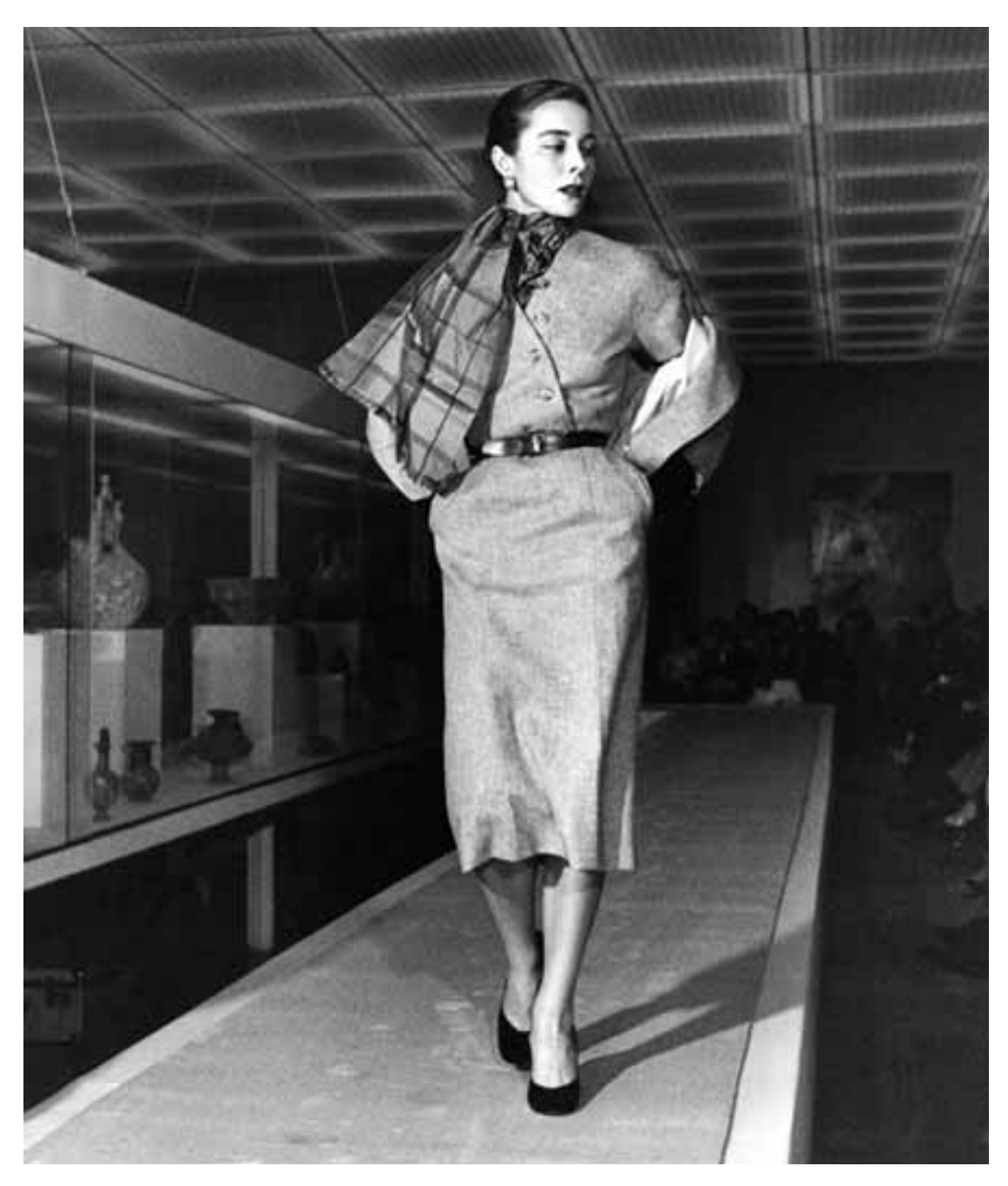




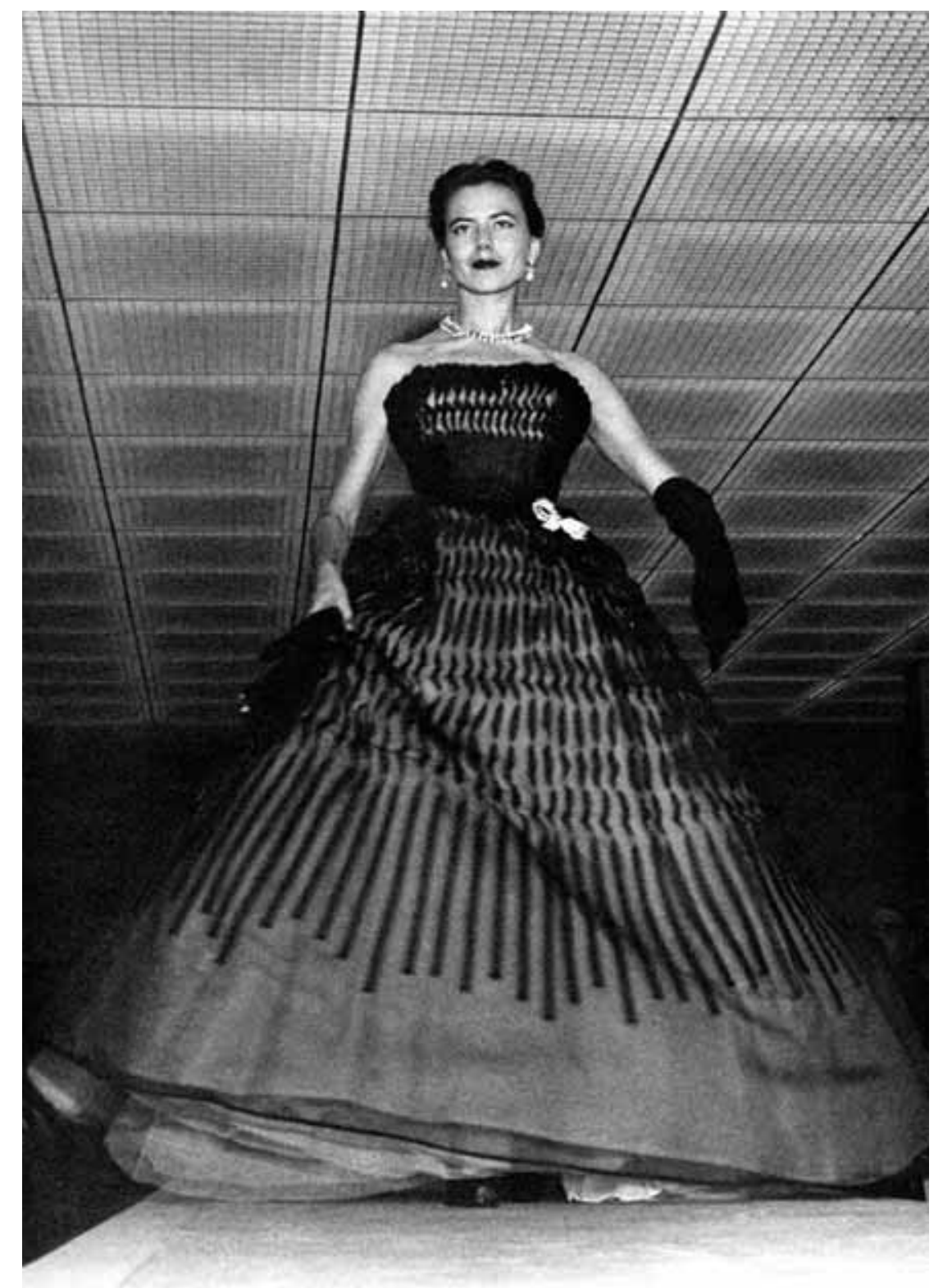

E o desfile se encerra de modo espetacular, com um traje criado por Salvador Dalí, um modelo que indicava o que as mulheres usariam no ano de 2045 , um vestido verde-claro, com bordados e furbante, usado por uma das modelos de Christian Dior e adquirido para o acervo do Museu, corroborando para o entendimento da moda enquanto expressão de grande relevância.

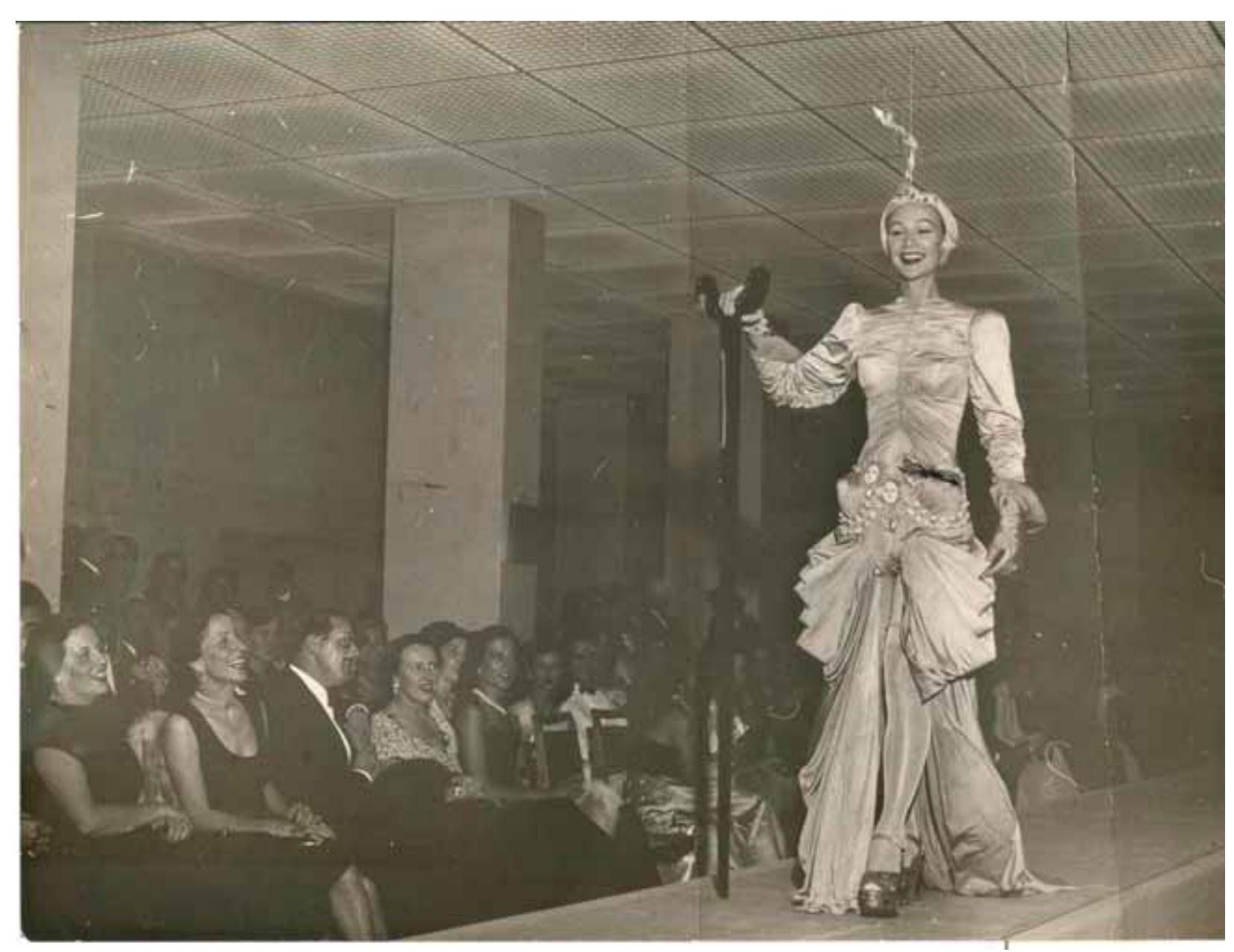




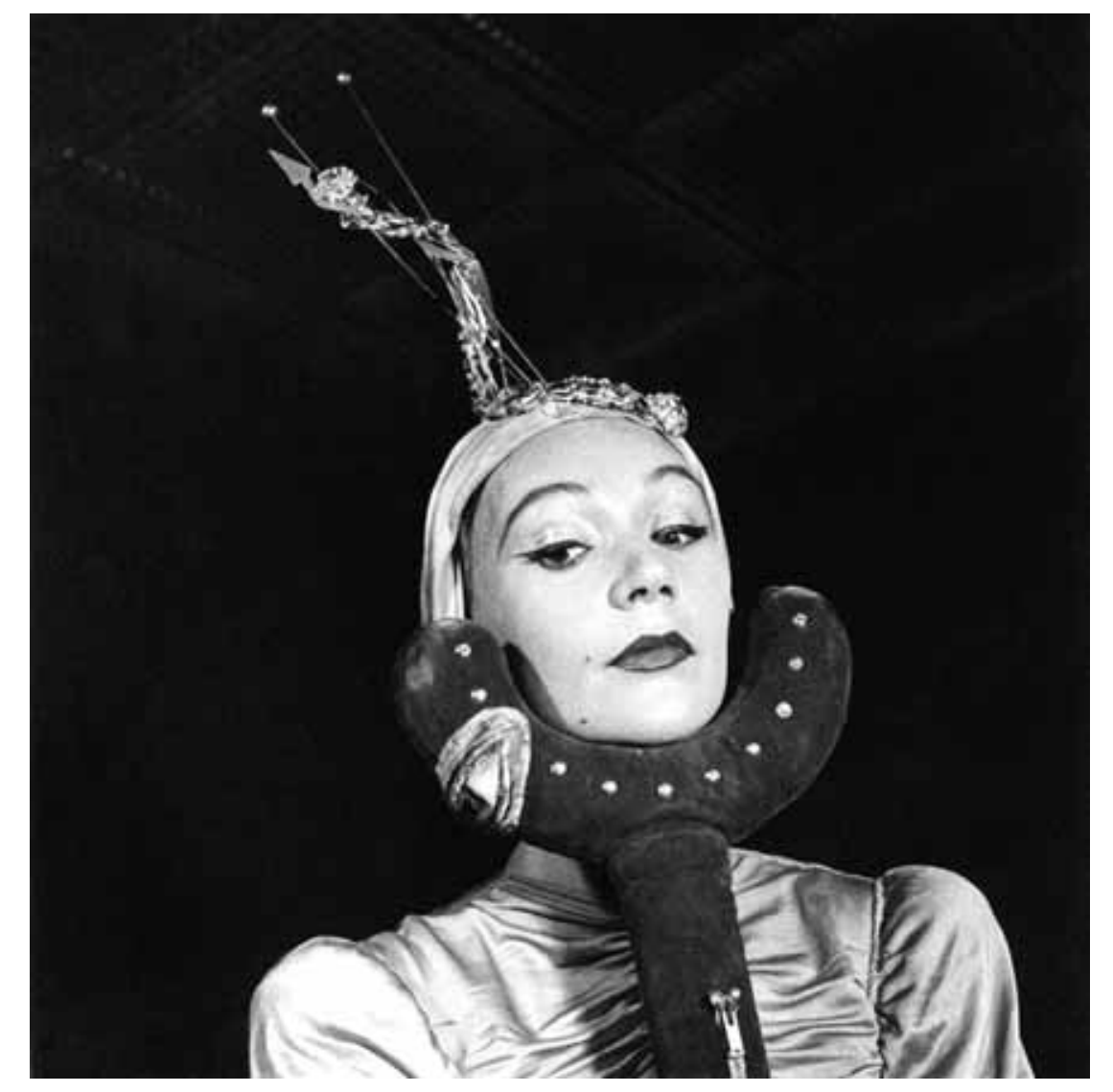

que todos os grandes museus modernos - como Metropolitan de New York - vem ultimamente demonstrando. E, graças a colaboração da famosa organização de Union Française des Arts du Costume que a instituição paulista conseguirá proporcionar ao nosso público tão brilhante desfile. Com esse movimento espera, sem dúvida, o Museu de Arte despertar, nas tradicionais famílias paulistas, 0 desejo de reunir em torno desta instituição antigos costumes que geralmente se conservam por razões pur amente sentimentais, mas que na realidade constituem um verdadeiro patrimônio cultural necessário a reconstituição do desenvolvimento da nossa arte e dos nossos costumes. Assim, pretende o Museu desenvolver a sua seção de vestuário que já é uma realidade graças ao gesto de benemerência do $\mathrm{Sr}$. Paulo que espontaneamente acaba de doar uma rica coleção de antigos costumes. (...)" 3

Pretendia-se, portanto, com esta iniciativa, demonstrar a importância da moda para um museu de arte, ao tratar o campo como um patrimônio cultural capaz de reconstituir o desenvolvimento da arte e dos costumes de um povo. O Primeiro D esfile de Costumes Antigos e Modernos proposto pelo MASP guardava ainda, entre as intenções já explanadas, a vontade de, à maneira do museu Metropolitan de Nova York, constituir uma seção de costumes no Museu, para a qua se solicitava a doação dos trajes antigos. novo empreendimento num tom de elevado gosto, nada mais faz que dar uma demonstração viva desse interesse pela moda

25 10 D ESFLL DE COSTUMES Antigos EModernos/D DEsLE DIOR 1951 lioteca e C entro de Documentação do MAS

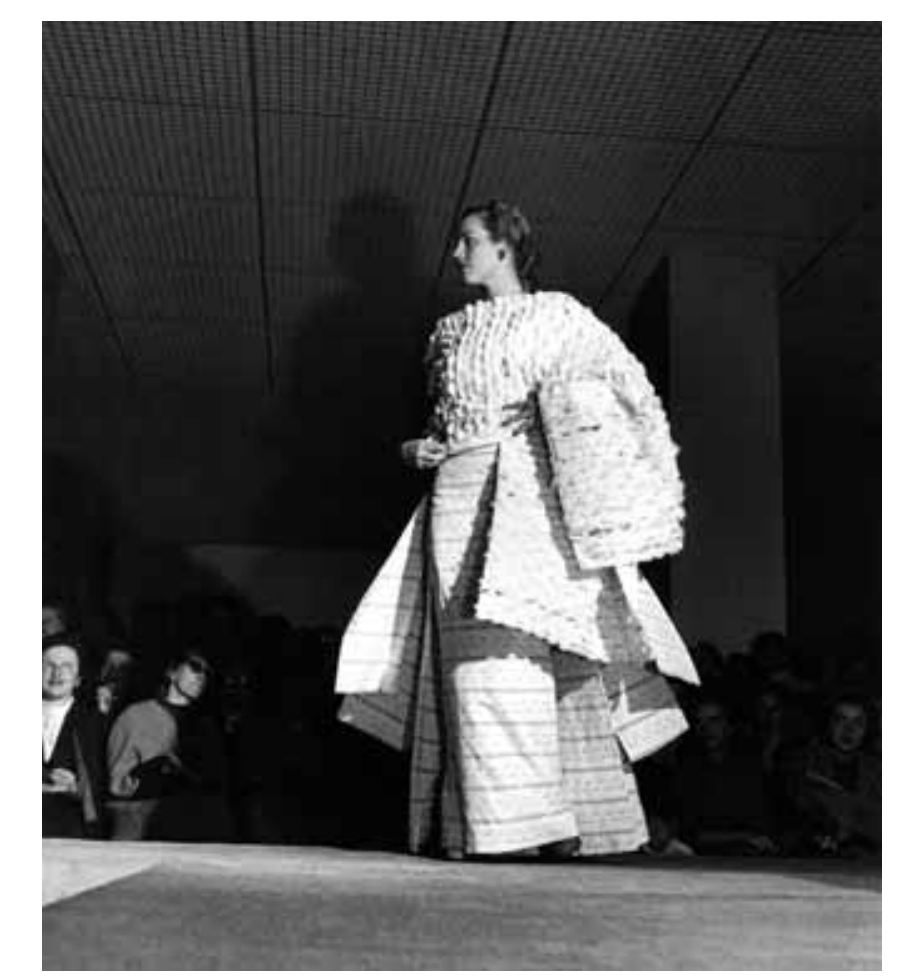


E o êxito do empreendimento é demonstrado pelo texto dirigido à imprensa, localizado em documento pertencente ao arquivo histórico do Museu:

"O desfile de modas que o Museu de Arte organizou para dia 27 é o primeiro de uma série que será periodicamente apresentada ao público no salão da Pinacoteca, como parte da nova iniciativa do Museu que constitui, assim, a sua Seção de Costume. 0 êxito dessa primeira manifestação deve-se ao Sr. Paulo Franco, diretor da Casa Vogue, e que tomou a si a tarefa de procurar em Paris e nos Estados U nidos trajes antigos pertencentes a museus e à coleção inédita do grande costureiro Christian Dior. Fica, pois, o Sr. Franco convidado a continuar à testa dos próximos desfiles, assim como da organização desta nova Seção de Costumes, que, a exemplo dos mais importantes museus do mundo, o Museu de Arte está desenvolvendo.

Como os diretores do Museu consideram a moda uma das mais importantes manifestações de arte, o Sr. P. M. Bardi dirige às famílias paulistas um apelo no sentido de que considerem a possibilidade de doar costumes antigos ao Museu de Arte; muitos destes costumes estão guardados em armários quando na verdade poderiam, graças à boa vontade e colaboraçâo destas famílias, enriquecer a coleção do Museu, concorrendo assim para o maior êxito dessa campanha que visa aumentar o nível cultural dessa metrópole.

A Diretoria do Museu de Arte agradece ao público que tanto abrilhantouaprimeiramostraedesdejáo convidaparaado próximo ano que contarátambém co ma organização do Sr.Paulo Franco."

Anos mais tarde, já em 1976, em entrevista de Pietro Maria Bardi dedicada à coleção de vestidos do Museu em grande parte, formada pela doação da coleção do costureiro Camilo Sabbazh (famoso em São Paulo nos anos 1920 e 1930) há a reflexão em torno das relações entre a moda e a arte:

"(...)Tudo começou em 1950, quando professor Bardi organizou a mostra do Cinquentenário de Arte Moderna e, entre quadro de Manet e Van Gogh, fez desfilar vestidos estampados por artistas da época:

- Eu descobri a moda. Resolvi colocar ao lado das obras de arte tudo o que era coisa do tempo, e por isso coisa de moda D escobri naquela época o C amilo, que foi o primeiro costureiro de São Paulo.D esvendei uma época rica quando os imperadores do café mandavam passar e engomar suas camisas em Paris. Foi uma grande surpresa reconstituir esse mundo perdido através das roupas do Camilo.

Daí em diante, o diretor do MASP ficou com uma ideia fixa: a criação do Museu do C ostume,um nome muito sério para uma ideia que, na opinião de muitos, não passava de uma brincadeira extravagante. Ele explica:

- Para mim. a moda é protoplasma da arte. Ela precede ou pelo menos convive, com um determinado momento estético, e como acredito que a arte é consequência do meio, o problema dos costumes é muito importante. Eu acho que a moda determina muitas tendências da arte. 0 vírus pega é como se uma mentalidade global se espalhasse como uma doença. A moda representa a urdidura, é o corpo invisíve que une os costumes e a expressão artística. (...)" 5

E no ano seguinte, em 1952, como continuidade à proposta de eflexão das relações entre moda e arte e, reiterando a ideia de arte e moda como consequências do meio, o Museu propõe uma iniciativa 
mais do que surpreendente. Nos ensaios anteriores, é amplamente debatida a visão de um campo ampliado da arte, no qual o design é manifestação; bem como os aspectos didáticos em relação à formação de um senso crítico na eleição dos objetos, da roupa, da visualidade plástica. Reflete-se também uma nova orientação do Museu e seu papel junto à sociedade, na medida em que instituição encarrega-se também de não somente formar opinião mas de formar profissionais para atuarem no nascente contexto de industrialização acelerada ao qual o País adentra. No $1^{\circ}$ DesfiLE DE Moda BrasileIRA, realizado em 1952, o Museu inovará mais uma vez, ao tomar para si a tarefa de concepção, produção, divulgação e comercialização de trajes, cuja intenção era nada menos do que naugurar uma moda brasileira.

"D entro em breve, o Museu de Arte de São Paulo apresentară no primeiro desfile de moda brasileira, cerca de sessenta modelos desenhados e confeccionados nas instalações de sua seção de moda.Trata-se de modelos ideados por artistas e para cuja confecção os tecidos foram especialmente desenhados por eles e alguns até tecidos nos teares do curso de tecelagem do Museu. 0 s artistas que colaboraram foram:Roberto Burle Marx Lilly Correia de Araujo, Roberto Sambonet e Caribé. A parte de tecelagem coube a Sra. Clara Hartoch, que vem orientando o curso de tecelagem do Museu. A foto acima focaliza $\mathrm{C}$ aribé, pintando, diretamente sobre o tecido, motivos da macumba. o conhecido artista baiano está atualmente em São Paulo, onde vem desenvolvendo a sua atividade no campo da arte $e$ do cinema. As manequins que apresentarão os modelos serâo todas escolhidas entre as alunas do curso de modelos que o Museu deA rte tem organizado contemporaneamente à seção de moda, para cuja realização a C asa Anglo-Brasileira tem dado o seu apoio e experiência."

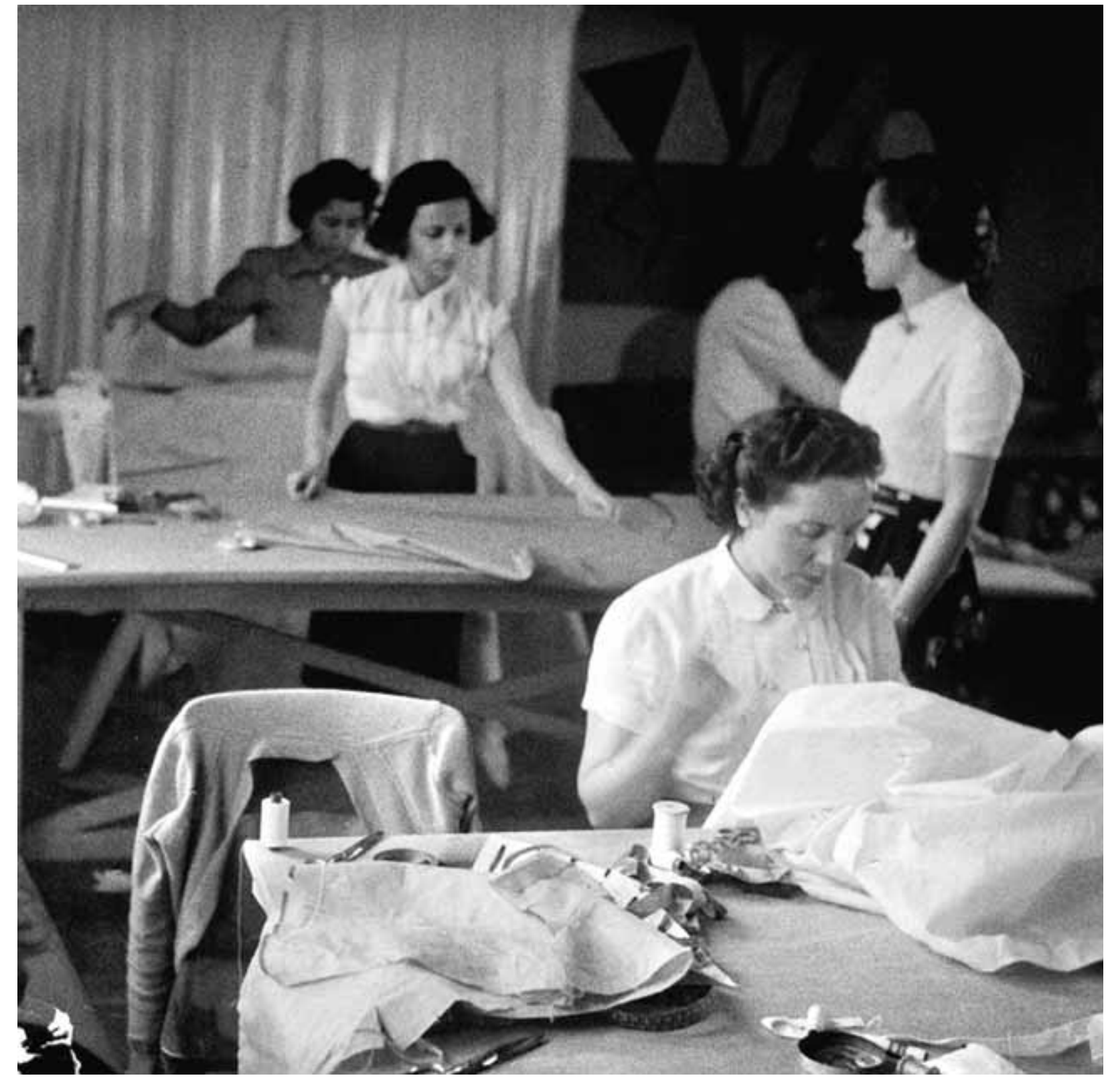

260 ficina no interior do Museu de Arte de São Paulo 1952 Biblioteca entro de Documentaçáa do MASP 
cartaz criado por Roberto Sambonet para o desfile concilia o rigor da precisão com o desenho de um esboço para um dos trajes exibidos e é ao som de músicas brasileiras que modelos como "Abacate", em gabardine de algodão para o uso na praia "Macumba", em algodão tecido à mão com palha, para os passeios no campo e "Favela", tecido à mão e tricô, para as noites quentes; entre outros modelos, num total de 50 figurinos - desfilaram no Museu inaugurando uma iniciativa ímpar. O Museu, com o patrocínio da Casa Anglo-Brasileira, havia montado uma oficina de costura em suas instalações, convidado artistas para desenhar modelos inspirados pela atenta observação da realidade brasileira formado modelos para o desfile e comercialização dos mesmos. $\mathrm{O}$ convite do desfile não somente apresentava a sequência, nome materiais nos quais os trajes foram elaborados, mas também os valores de cada um deles. Após o desfile, os modelos apresentados encontravam-se à venda nas Casas Mappin, em São Paulo.

O Museu, com sua iniciativa, de alguma forma, antecipa décadas antes, a apropriação da paisagem brasileira como estratégia fundamental na concepção de objetos, que tornam hoje designers, que utilizam este recurso, como Fernando e Humberto Campana de relevância internacional. Basta lembrar que a cadeira "Favela" um dosgrandesícones da produçãodos designerse coincidentemente um dos trajes apresentados também se chamava "Favela".
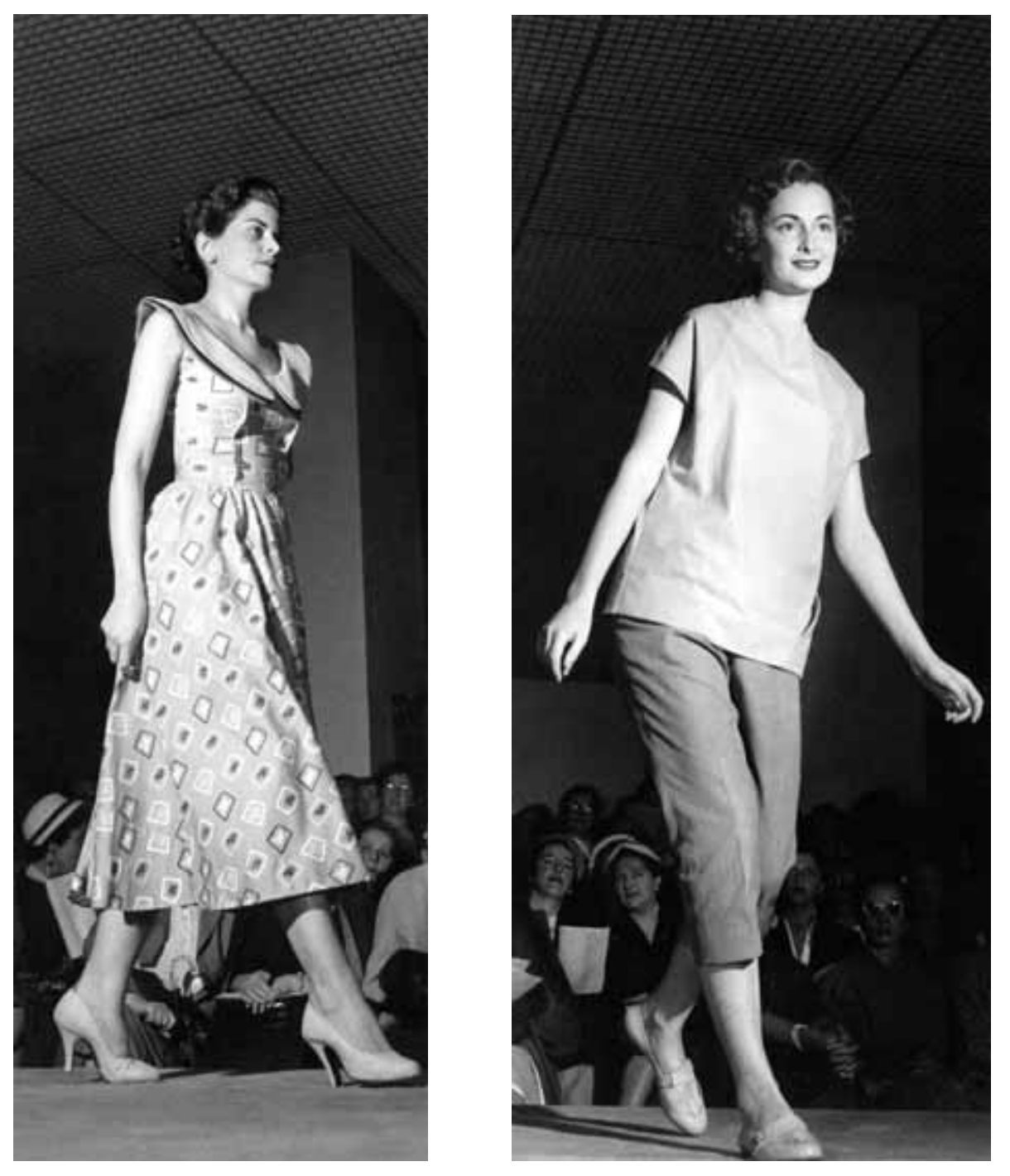

27 10 DESFLL DE Moda BRAsLlEIPA 1952 Biblioteca e Centro de Documentação do MASP. 


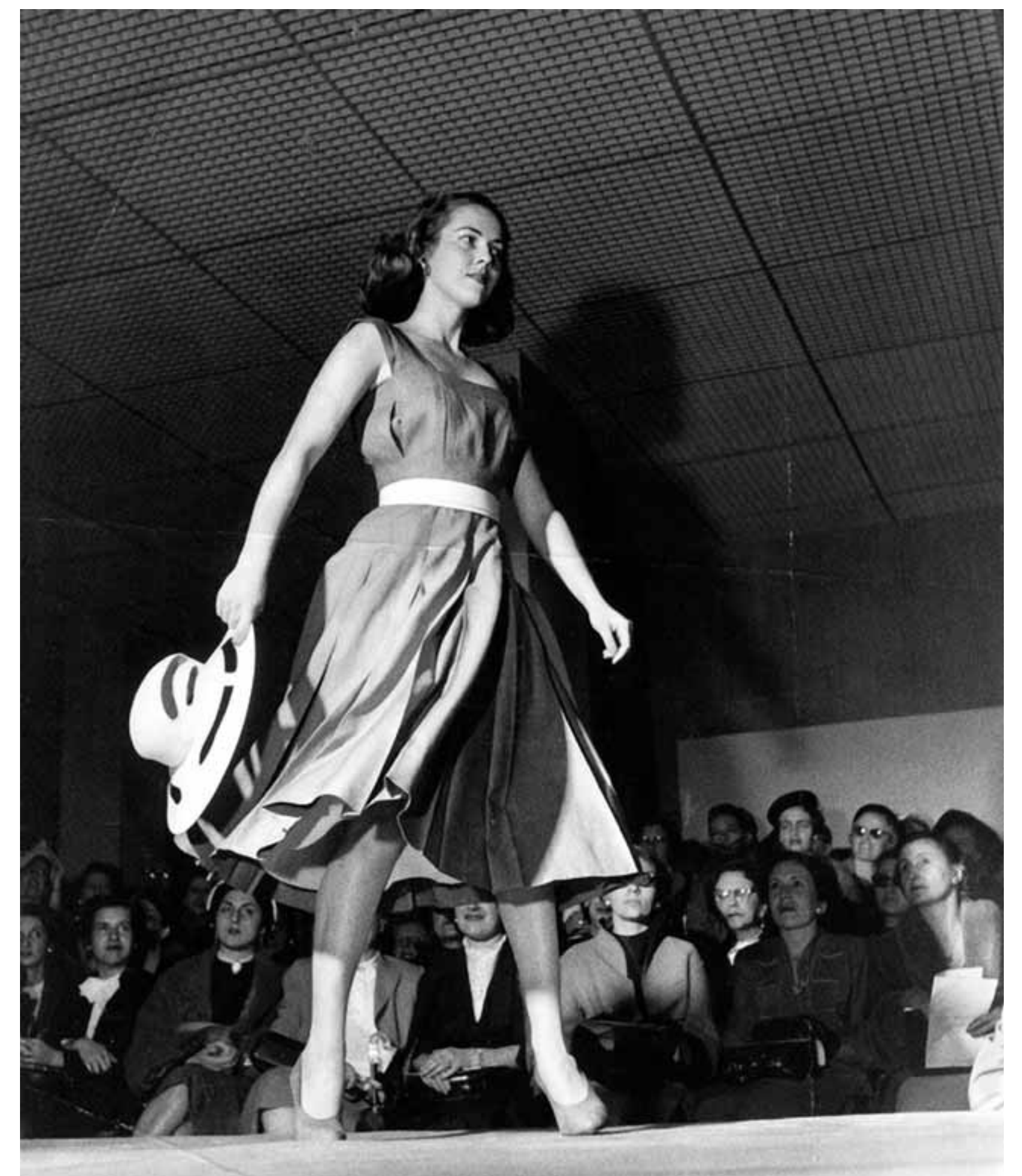

Há manuscritos em italiano localizados no arquivo histórico do Museu, de provável autoria de Lina Bo Bardi, de grande relevância para a compreensão da proposta, nos quais o tema da moda visto como uma lacuna preocupante no Brasil, na medida em que, no País, "moda" era um sinônimo de aquisição em Paris, Itália ou Nova Iorque. Nas palavras de Lina:

"(...) um fenômeno bastante preocupante, ao menos, a preocupar as pessoas inteligentes e responsáveis."

E o texto prossegue:

O Museu instituiu um "Centro de Estudos para a Moda Brasileira", sob o patrocínio da Casa Anglo-brasileira É em 6 de novembro próximo, depois de longos meses de trabalho e estudo, o primeiro desfile de moda brasileira, inteiramente inspirada na realidade do Brasil, fruto de pura invenção e de atenta observação da verdade: a flora, o clima, a estrutura do nosso País. 06 de novembro será considerado como um dos momentos centrais para a história do costume brasileiro.

O evento de grande significado e repercussão surge como uma ação efetiva por meio da concepção dos trajes para inaugurar e projetar uma moda brasileira tanto em âmbito nacional como internacional. Aqui, ao iniciar a reflexão em torno da pesquisa de linguagens, técnicas, materiais próprios do País para a criação de uma linguagem estética coerente com o meio no qual a criação se dá, o discurso limita-se ainda, a meu ver, a apropriação da paisagem como elemento inspirador. Esta proposição ganhará outros contornos e uma maturidade aprofundada na exposição A Mão do Povo Brasileiro, em 1969, imediatamente após a inauguração da sede do Museu na Avenida Paulista. 


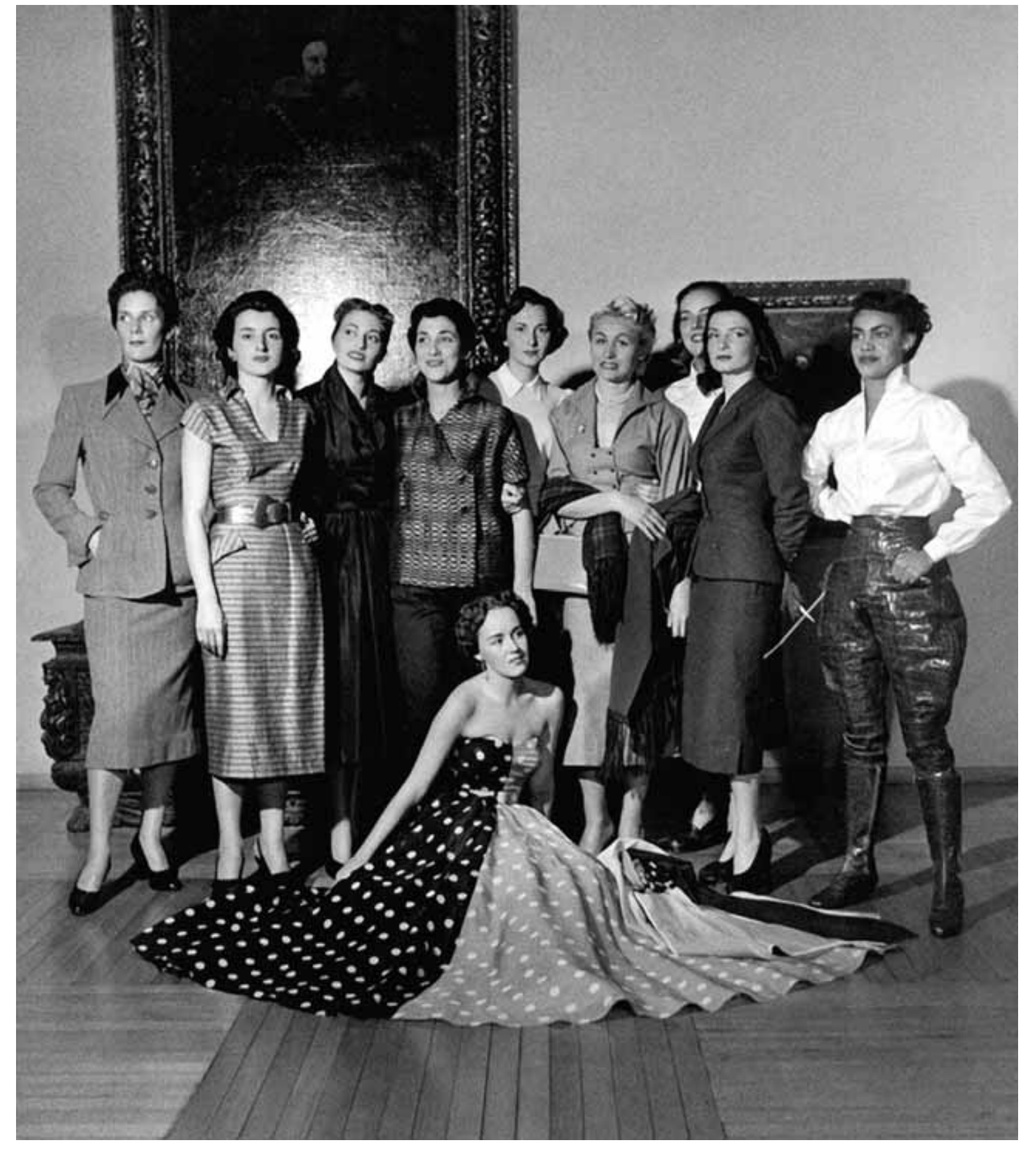

A iniciativa dirigia-se também às indústrias brasileiras, sobretudo às têxteis, que em grave crise à época, porém, formavam o maior parque industrial do País. Tratava-se, desde aquela década de estimular empresários a investir em pesquisa e desenvolvimento em busca de uma produção original e capaz de concorrer em âmbito internacional; proposta está adotada pela Rhodia nos anos seguintes. E é João da Costa Doria, publicitário e político que, em texto bastante lúcido publicado à época, traz a discussão:

"Q uando os produtores brasileiros deixarem a caverna neolítica em que se guardam e puserem o cérebro a funcionar tanto quanto suas máquinas, em torno de ideias destinadas à promoção de vendas - nesse dia, hão de preferir planos de publicidade em lugar de ofícios e memoriais reclamando auxílio e amparo do governo. (...)

o Museu de Arte organizou uma escola de modelos vivos e deu, outro dia, a sua primeira mostra, apresentando criações inéditas de moda brasileira com tecidos fabricados nos próprios teares do Museu e por indústrias paulistas. Terá sido mostra elegante, para servir de assunto às crônicas sociais? $\mathrm{O}$ u os representantes da indústria têxtil terão enxergado perspectivas novas de expansão comercial nas estamparias originais, pintadas à mão por Caribé, esse portenho que ama e interpreta motivos essencialmente brasileiros, colhidos nas coisas e graças da Bahia?

A iniciativa do professor Bardi caberia ao Sindicato de Fiação e Tecelagem. 0 s capitães da indústria têxtil deveriam subvencionála, recrutar artistas para se ocuparem da recuperação do tecido nacional e da conquista de padrões técnicos e artísticos genuinamente brasileiros, fora das imitações vulgares do que se faz lá fora. 
$N$ ão esqueçamos que os teares franceses produzem tecidos para atender a uma procura que é fruto exclusivo da arte e do bom gosto de artistas, que ditam as padronagens, e costureiros, que emprestam beleza e elegância às suas criações. Revistas de moda são financiadas pela indústria têxtil e têm por objetivo influenciar através do lançamento da moda, a preferência dos mercados consumidores pelos artigos de sua fabricação. Paris, Londres, Roma, Hollywood e N ova York tornaram-se metrópoles da moda feminina porque souberam mobilizar ao lado da técnica que produz a qualidade, artistas criadores, que realizam o belo. Eles, afinal, decidem com o apoio da publicidade bem orientada, o gosto, a preferência, a escolha e compra de milhões de consumidores.

Até há pouco não podíamos competir com centros internacionais da moda nem, por trás deles, com os poderosos teares da França, Inglaterra, Itália e Estados U nidos. Não obstante, duas iniciativas recentes - a campanha do algodão e a escola de modelos do Museu de Arte - mostram a possibilidade vantajosa no mercado internacional com os nossos tecidos de algo dão, de lã, de seda, de rayon, de linho inclusive - cuja qualidade já rivaliza em muitos casos com produtos estrangeiros.

Deixemos de lado os acordos e convênios entre governos para empurrar os "abacaxis" de nossa produção a preços superiores aos da paridade internacional.

Cuidemos, em primeiro lugar, de valorizar o nosso artigo, elevar os níveis de qualidade e apresentação. 0 que as máquinas francesas e italianas são capazes de fazer, as nossas também 0 são. 0 que importa é trabalhar com a cabeça, pensar não só em termos de produção em série, mas de ideal artístico, que aperfeiçoe e embeleze o produto, e de uma política comercial moderna, que elabore planos de promoção de vendas.
As cartas estão conosco e o coringa também. Temos a chave que expande mercado internacional para os nossos tecidos.Aí está a paisagem brasileira, no que tem de peculiar, de original, arte tropical, o homem tropical, costumes tropicais... Coisas nossas, características nossas. Convoquemos o intelectual 0 artista a participar desse movimento de renovações da indústria. C hamemos Portinari, C aribé, G raciano, D i C avalcanti, José Valadares, $\mathrm{O}$ dorico Tavares, G ilberto Freyre, Mario Cravo, lean Manzon, Francisco Albuquerque para darem palpites sobre a Moda Brasileira, os padrões e estampas que os nossos tecidos possam apresentar no sentido da criação do estilo tropical. lancemos ao mundo, ao som de frevo e ritmos do pandeiro em desfiles, recepções, crônicas, anúncios e figurinos - a Moda Tropical Brasileira. Façamos do Brasil o paraíso de modelos tropicais. Este lugar está vago no reino da arte de vestir. $\mathrm{N}$ em Roma, nem Paris, nem Hollywood. É um lugar reservado para nós. Vivemos nos trópicos há mais de 400 anos. Podemos ser doutores em moda tropical, em moda brasileira. Então em cada metro de tecido exportado imprimiremos criações exclusivamente nossas, que o estrangeiro acolherá maravilhado, pois nesses tecidos vai encontrar ideias, cores e formas.

A propaganda do IV Centenário de São Paulo reclama iniciativas como esta. Reúnam-se em mesa redonda, Jafet, Bardi, Ermírio de Morais, Matarazzo Sobrinho, Devisate, Camargo e decidam auxiliar a iniciativa do Museu de Arte. E mandem seus manequins, por esse mundo afora, a desfilar pelas grandes capitais mostrando arte e 0 bom gosto dos tecelões e costureiros do Brasil e, com eles, o sabor tropical de nossa paisagem, a estilização moderna de nossa indumentária, os traços marcantes de nossa cultura, no corpo sinuoso e moreno dos nossos modelos vivos. Para acompanhá-los, bastará um representante da Indústria de Fiação eTecelagem, de caderno e lápis na mão, para assentar pedidos." 
Desde 1952, o texto elabora uma crítica contundente à inércia do empresariado brasileiro, acostumado, desde os ciclos de exploração, a barganhar vantagens e proteção do governo para a valorização do seu produto e proteção ao seu mercado consumido ao contrário de investir em pesquisa e desenvolvimento para tornar o produto nacional altamente competitivo. E arte é proposta como instrumento de ação, na medida em que o estreitamento das relações entre arte e indústria, favorecia o desenvolvimento de uma produção original. É possível dizer que o autor estaria entre os precursores de uma estética tropicalista, na medida em que defende o fortalecimento de uma linguagem estética ligada a algumas imagens da cultura brasileira.

O debate das relações entre arte e indústria e o discurso voltado ao empresariado brasileiro será um dos temas amplamente abordado pelas exposições do Museu, sobretudo a partir dos anos 1960. Porém, é somente na década de 1990, com a adoção de políticas econômicas abruptas de abertura ao mercado internacional, que a indústria nacional orientar-se-á de forma mais clara efetiva à busca de estratégias alternativas às velhas práticas de barganha política.

O debate em torno de uma linguagem estética afeita aos aspectos da cultura local reforça a amplitude do debate em torno da adoção de modelos para o design brasileiro. Tal debate, desde a década de 1950, revela, portanto, que o coro não é uníssono em relação à adoção da estética modernista. Há outras vozes em torno do tema e a predominância de uma linguagem internacional como modelo, sobretudo, para o ensino nas escolas de design no País se dará em função de fatores mais complexos, porém, desde já é fundamental reconhecer a amplitude da discussão ainda no período.

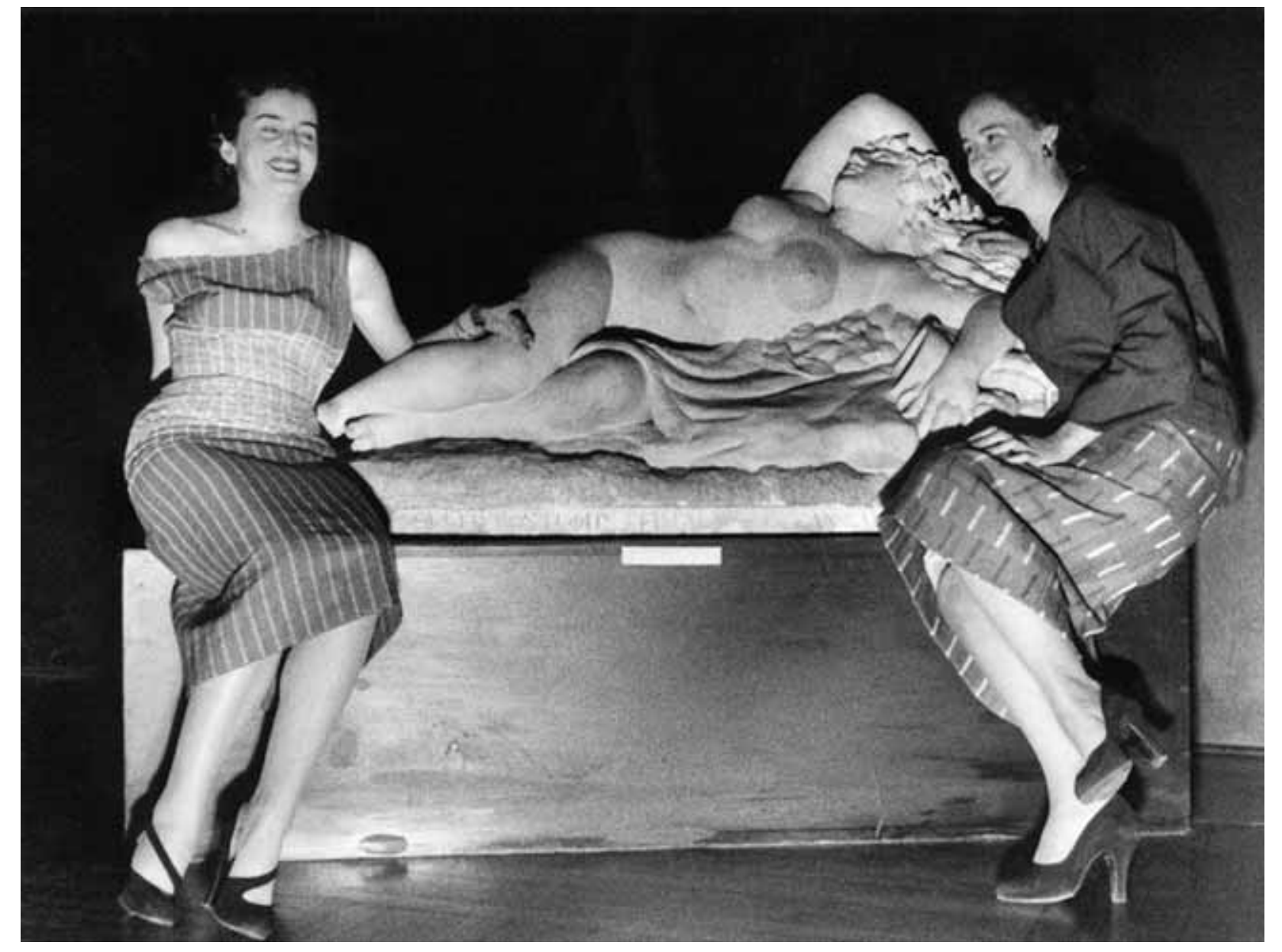

A riqueza do debate proposto pelo Museu para o campo da moda é impressionante. São muitas as atividades propostas nos anos seguintes e que reveem o debate das relações entre moda arte e indústria e moda como arte. Estão entre elas as iniciativas da Rhodia em torno do patrocínio de artistas para o incremento da sua produção. Já próximo ao final de sua gestão, em 1987, Pietro Maria Bardi retomaria a reflexão das relações entre arte e moda por meio da exposição, cujo título, nos deixa a pergunta, ainda válida: TRAJE - UM OBJETO DE ARTE? 


\section{NOTAS}

1. Parada de modas deste e de outros tempos. Esplendor da costura francesa na "Passarelle" instalada no Museu de Arte. Diário da manhã, $1^{\circ}$ de abril de 1951.

2. BAUDOT, François. Moda do Século: François Baudot. São Paulo Cosac Naify, 2002. p. 144-148

3. Trecho transcrito diretamente de documento pertencente ao arquivo histórico do Museu cujo título é Material para a imprensa Da EXPosição Desfile Dior DE 1951

4. Trecho transcrito diretamente de carta dirigida à imprensa pertencente ao arquivo histórico do Museu.

5. O Baú do Museu do Costume. Jornal da Tarde, 20 de maio de 1976

6. Trecho transcrito diretamente de documento pertencente ao arquivo histórico do Museu cujo título é Desfile de Moda Brasileira no Museu de Arte de São Paulo.

7. Trecho transcrito e traduzido pela autora diretamente de manuscrito pertencente ao arquivo histórico do Museu cujo título é $1^{\circ}$ DesfiLe DE Moda Brasileira.

8. Trecho extraído de fortuna crítica localizada no acervo histórico do Museu de Arte. In: DORIA, João da Costa. Paraíso De Modelos

Tropicais. O Estado de São Paulo, Suplemento Feminino. p.8 e 9. 


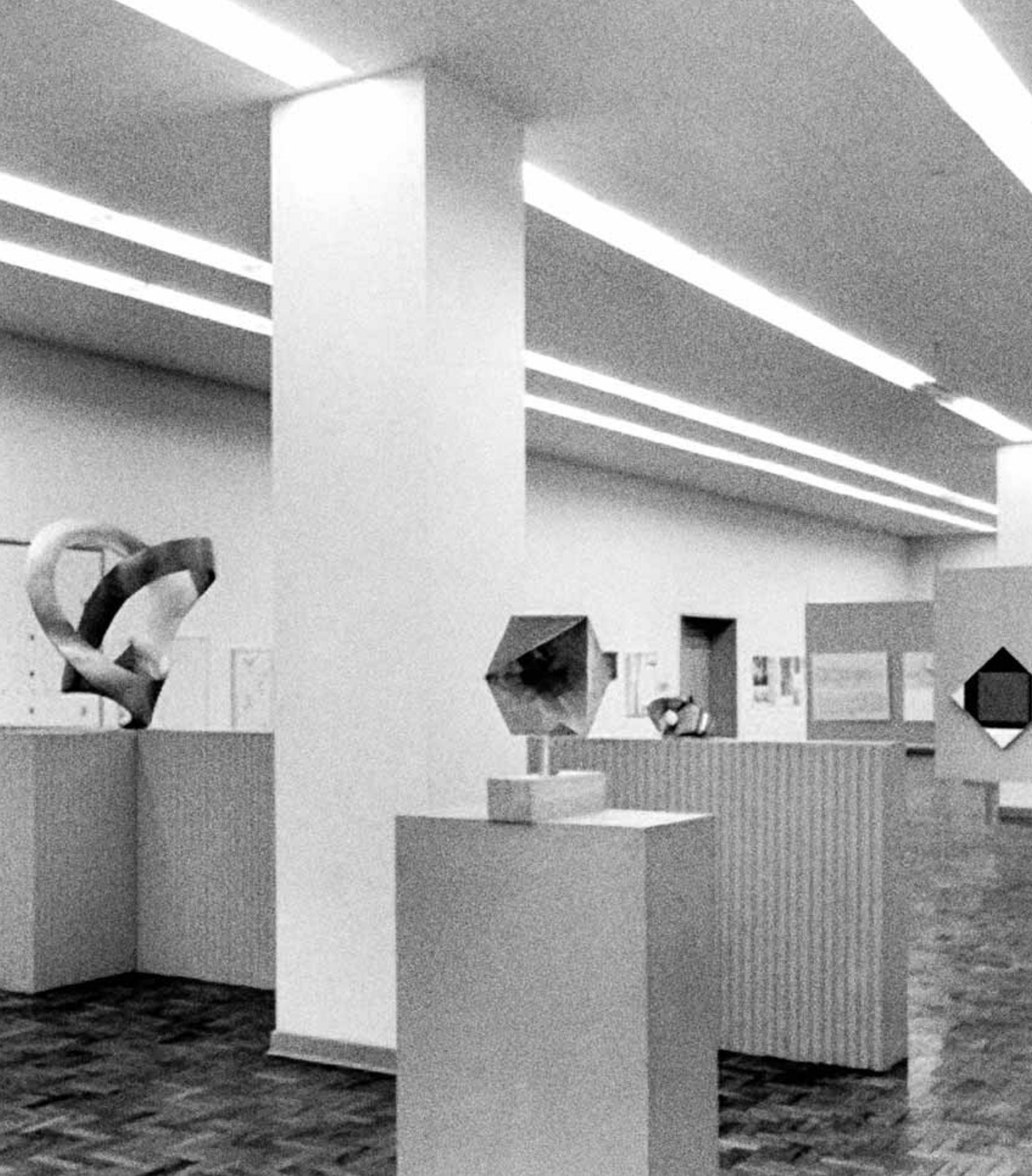

\section{4 \\ 0 PAPEL DO MASP NA DIFUSÃO DO DISCURSO MODERNISTA (1950-1989)}

É incontestável o papel e a contribuição do Museu de Arte de São Paulo em torno da reflexão dedicada à presença das correntes abstracionistas no País ${ }^{1}$. Desde a sua fundação, em 1947, os debates promovidos pelo Museu já resultavam em acaloradas discussões sobre a figuração e abstração. Entre estes, Amaral cita os depoimentos de Jorge Romero Brest, crítico e historiado da arte, realizado no MASP e Leon Dégang, primeiro diretor do MAM-SP, realizado na Biblioteca Municipal, como importantes contribuiç̃os ao tema do Abstracionismo.

No entanto, os ecos da abstração geométrica antecedem a fundação do Museu e já eram sentidos no Brasil desde o início dos anos 1920. A SEMANA DE FEVEREIRO DE 1922, conhecida como Semana de Arte Moderna, já abrira espaço para um grupo reunido sob a égide de atualização da expressão plástica e literária segundo os princípios da modernidade. Neste contexto, a revista Klaxon foi um exemplo da busca por uma nova visualidade, distante dos princípios gráficos identificados com o século XIX e as primeiras
32 EXPO SIÇÃO MAX BILL 195 Documentaçâo do MASP 
são reconhecidas em três momentos: no primeiro, em especulações abstrato-geométricas em telas do início dos anos 1920, presentes na obra Composição Abstrata, de Vicente do Rego Monteiro, datada de 1922; no segundo, em fundos de tela cujo primeiro plano é figurativo, visível na tela $A$ negra, de Tarsila do Amaral, realizada em 1923; e no terceiro momento, mais significativo, nas decorações de interiores, cenografia e vitrais presentes nas obras de Lasar Segall, Antônio Gomide, Regina Gomide Graz e John Graz. ${ }^{3}$

Flávio de Carvalho também exerceria um papel fundamental no meio cultural paulistano, sobretudo na organização do III SALÃo DE MAIO, de 1939, segundo Amaral, por três razões significativas:

“(...) Primeiro, por ter produzido um catálogo bilíngue, - que demonstra seu interesse em exportar suas ideias $e$ é o primeiro documento relativo ao modernismo nos anos 20, visto já em retrospecto, com depoimentos de vários de seus participantes. Segundo por portar um Manifesto do III Salão de Maio, distante das preocupações sociais e regionais imperantes em geral entre os artistas brasileiros e estrangeiros à época, mencionando a "busca para uma sensibilidade maior".

(...) A terceira razão de relevância deste III Salão de Maio de 1939, em São Paulo, resulta da consequência dos itens anteriores: ele é, de fato, 0 antecedente direto das Bienais Internacionais de São Paulo, nele já despontando artistas destacados no meio artístico internacional, e pela intenção implícita no manifesto, de trazer polêmica das novas tendências contemporâneas da arte - o surrealismo, com ênfase, porém no abstracionismo." 4

Em relação à Semana de Fevereiro de 1922, o III Salão DE MAIO propõe o distanciamento às preocupações sociais regionais presentes na proposta antropofágica em direção à pesquisa de uma visualidade purista vinculada às vanguardas soviéticas e holandesas, ou seja, ao discurso internacional. Não é menos significativo que uma das propostas que mais chamou a atenção dos visitantes foi a de Jacob Ruchti, arquiteto formado pelo Mackenzie, escultor e designer de interiores, que apresentou seu trabalho em alumínio, Espaços, pioneiro na linha construtivogeométrica. Ruchti ${ }^{5}$ ainda desempenharia nos anos seguintes um importante papel junto a Francisco Matarazzo Sobrinho, o Ciccilo, na organização do Museu de Arte Moderna de São Paulo o MAM-SP, e do Instituto de Arte Contemporânea, no MASP.

Desde 1948, seja pela emergência da tendência ou pela influência dos debates, muitos artistas já faziam experiência abstrato-geométricas. Waldemar Cordeiro, Luís Sacilotto, Antônio Maluf, Mary Viera, Weissmann, Samson Flexor, Almir Mavignier Serpa e Palatnik, estão entre eles. Nesse período também se afirm a produção crítica de Mário Pedrosa, crítico que acompanhará e estimulará as inovações estéticas nos anos seguintes, sobretudo após a ExPosição DE MAX BILL no MASP, em 1951.

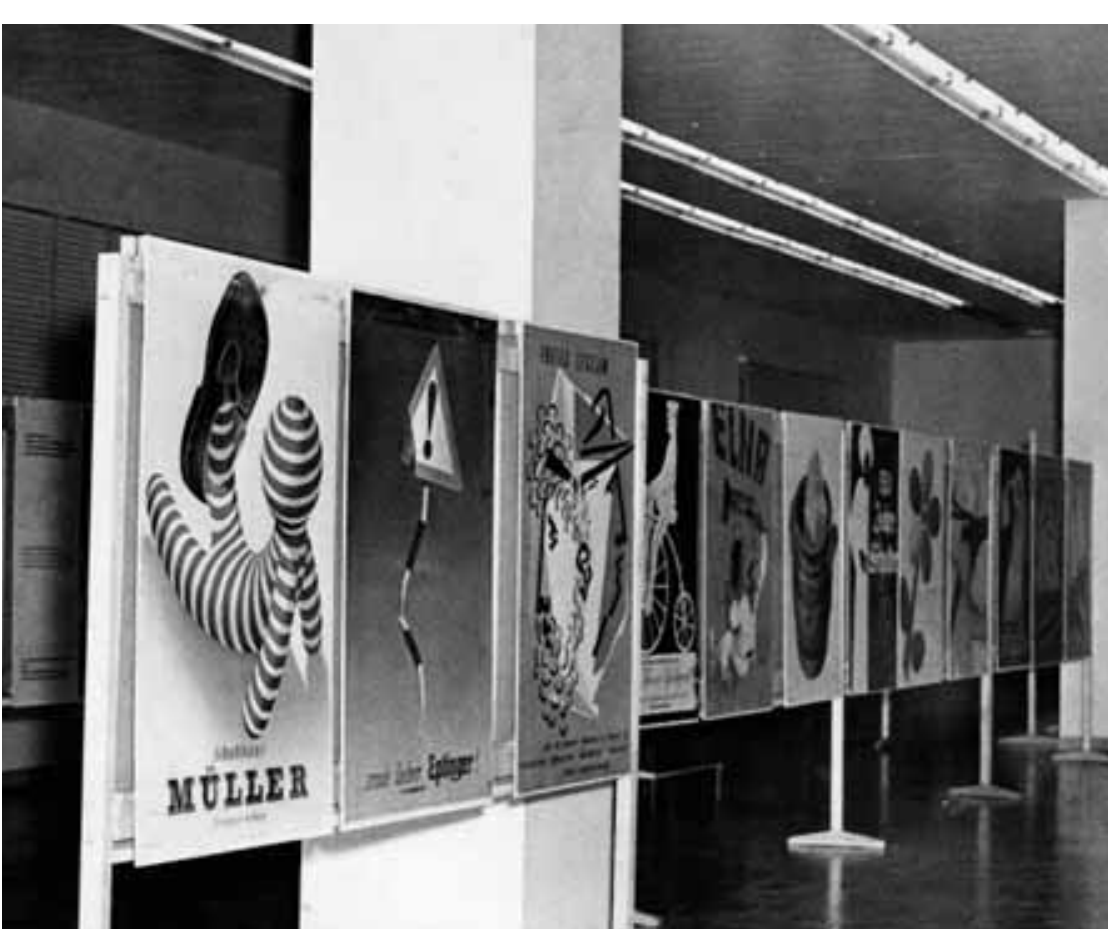




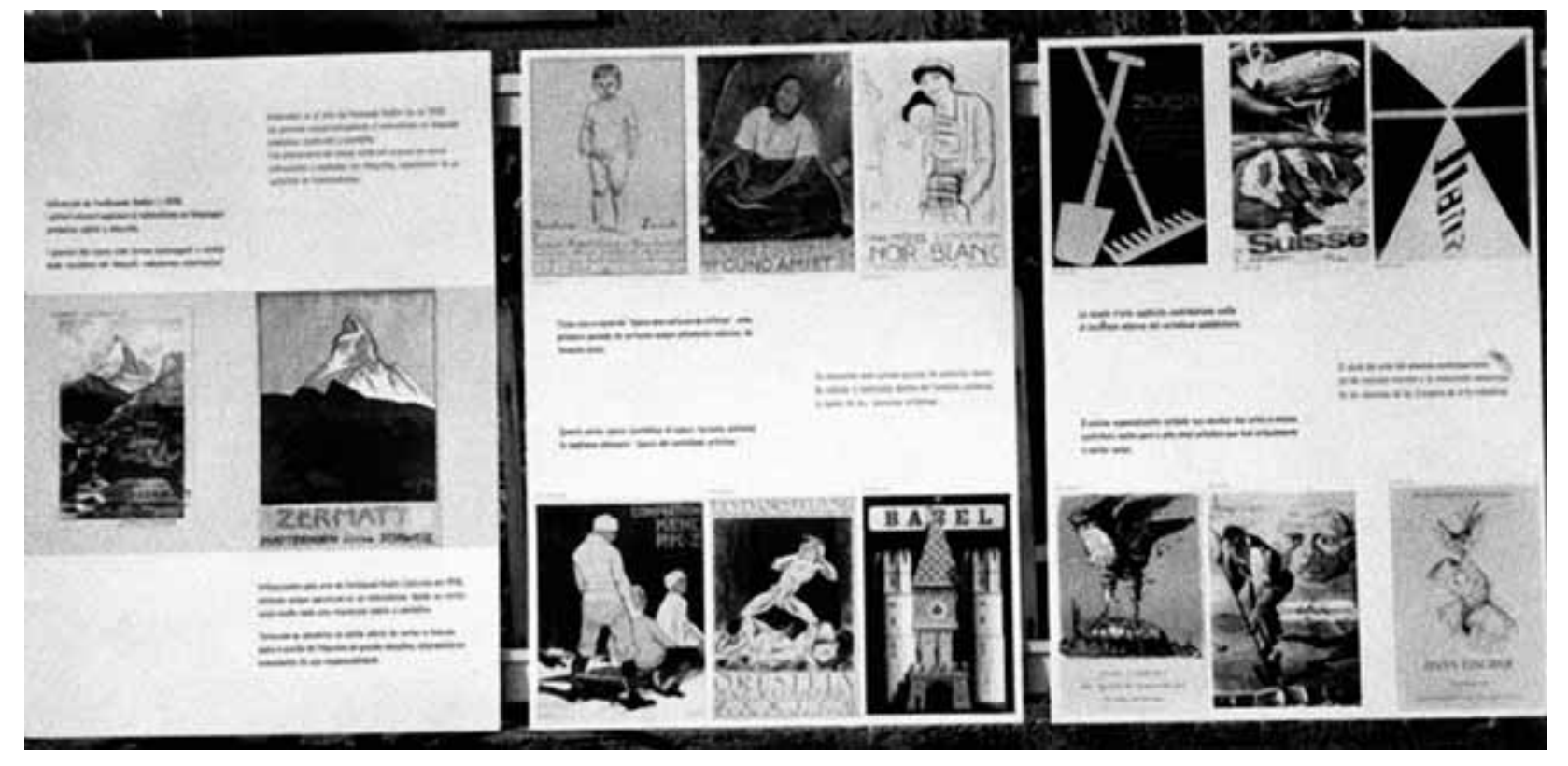

Posterior a Exposição de CARTAZes Sú́ços, ocorrida também no Museu, em 1951, a antológica Exposição DE MAX BILL - aberta nas instalações do Museu em 01 de março de 1951, na mesma data em que são inaugurados os cursos do Instituto de Arte Contemporânea (IAC) no Museu - é a mais importante dedicada ao tema do Abstracionismo, e já amplamente debatida pela historiografia da arte e do design brasileiros. É possível citar ainda ao longo das atividades do Museu, a Exposição Le Corbusier, em 1950, na qual foram também exibidos seus mobiliários a Exposição WarchavchiK e as Origens da Arquitetura Moderna no Brasil, em 1971, a Exposição Retrospectiva de Jonh Graz, em 1974, a Exposição De Stijl, em 1976 e, já na década de 1980, a Exposição Le Corbusier E O BRASIL, em comemoração ao centenário do arquiteto francês, em 1987, e a Exposição Alvar AALto, do arquiteto e designer finlandês, em 1989

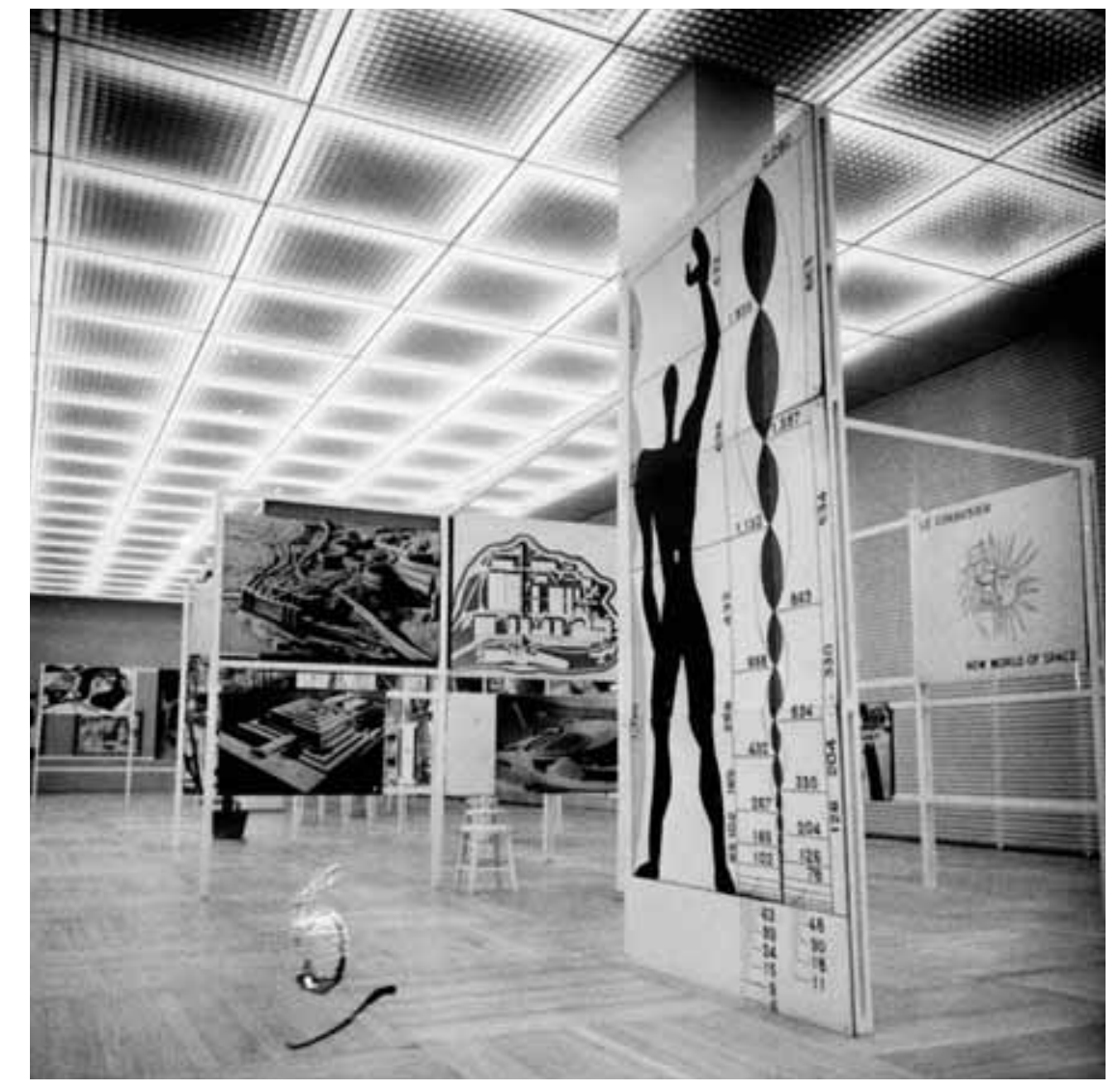

34 Expo siç̧̄o LE CORBUSER 1950 Biblioteca e Centro de

35 ExPO SIÇÃo LE CoRbuSIER 1950 Biblioteca e Centro de

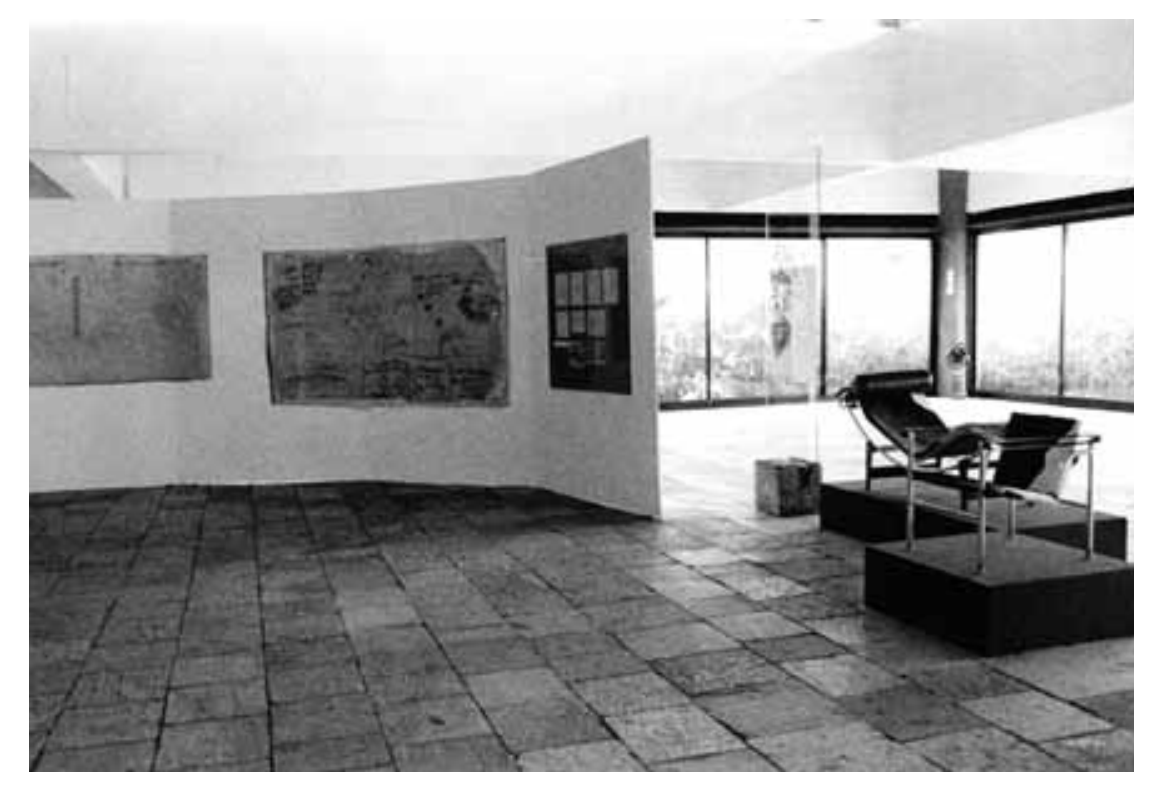


Sobre tais apontamentos, aparentemente há pouco a acrescentar, na medida em que é amplamente sabido que a repercussão da exposição e a consecutiva participação do suíço na I BIENAL INTERNACIONAL DE São PAUlo estabeleceriam novos paradigmas em grande parte dos artistas e designers em formação no País. A escultura Unidade Tripartida, vencedora do primeiro prêmio da I BIENAL, seguiria diretamente das instalações do Museu à Bienal. No entanto, se a Exposição MAx BILl dedicada ao artista suíço parece fortalecer o discurso de orientação modernista é fundamental compreender qual é exatamente o pape do Museu na consolidação da linguagem abstracionista à luz da totalidade de sua atividade.

Se, inicialmente a proposição do discurso da estética moderna como a mais adequada às perspectivas da industrialização parece se insinuar, porém a prevalência do modelo de origem germânica como linguagem estética para o desenvolvimento do design no Brasil se dá, se analisadas as proposições do MASP ao longo de sua história, por aspectos mais amplos e complexos do que por ênfase do Museu ao discurso.

Um dos aspectos mais relevantes é, antes de tudo, a compreensão acerca da proposta e adoção de um entendimento ampliado do campo da arte defendido pelo Museu. Defende-se a visão da arte como consequência do meio, tema já amplamente dissertado no ensaios anteriores dedicados às ExposiçõEs DidéticAs, que inclu o design como um fenômeno também artístico, uma vez que este contém em si e representa uma síntese dos aspectos técnicos, históricos e estéticos de uma determinada sociedade, num contexto de tempo e espaço específicos e, portanto, manifesta a expressão dos costumes e dos saberes de uma sociedade.

Uma vez considerado este aspecto, fundamental e presente ao longo de toda a atividade do Museu durante a gestão de Pietro Maria Bardi, a presença e o debate em torno da arte abstracionista no Museu não se dá necessariamente na defesa da adoção deste ou daquele vocabulário formal, mas numa perspectiva didático- histórica. O Museu, ao tomar para si um papel completamente original na promoção do debate acerca das manifestações estéticas, de diversas naturezas - um papel didático junto à sociedade paulista - também reitera e defende uma visão histórica acerca dos campos da arte e do design, objeto desta reflexão. Esta visão histórica é compreendida pela defesa de uma "moral" à criação de natureza artística, referindo-se a uma coerência da produção às características do seu tempo, isto é, a pertinência às técnicas, materiais e condições histórico-culturais propostas pelo contexto no qual ela se dá.

“(...) Mas não parou aí a série de exposições didáticas organizadas pelo Museu de Arte de São Paulo. Foi também organizada, no momento em que se estabeleciam os debates entre arte abstracionista e arte figurativa, uma mostra didática, fundamentada em fatos históricos, rica de argumentos e ilustrações e que procurava esclarecer o público - muitas vezes desorientado por polêmicas que visam mais agitar do que construir.A orientação adotada nesta mostra não implicou de forma alguma na adoção de qualquer atitude partidária por escola ou tendência. Propunha-se apenas orientar o público, através de dados o bjetivos, fundados numa razão histórica.(...)" 6

Por conseguinte, a presença do discurso abstracionista sobretudo acerca das suas relações com o design, se apresenta como mais uma das expressões artística, fruto de uma compreensão histórica, na medida em que a defesa ao artista moderno se da enquanto sujeito que domina materiais e técnicas próprios de sua época e, não necessariamente, na defesa da adoção do vocabulário formal estritamente modernista. O debate em torno do design proposto pelas inúmeras exposições exibidas pelo Museu, do objeto, gráfico, da moda é extremamente amplo e diversificado e não necessariamente corrobora com a adoção da estética de matriz 
funcionalista ao desenvolvimento do design no País. Reitera, isto sim, a reflexão em torno de um fazer em constante diálogo com a arte e coerente com aspectos técnicos, históricos e estéticos da sociedade que a produz. Esta visão pode ser confirmada por meio de artigos publicados à época na revista Habitat ${ }^{7}$ :

"O desenho industrial, este conceito que há mais de meio século vem revolucionando o ambiente em que se desenrola a vida contemporânea, atinge tudo quanto nos rodeia, propõe uma nova educação visual e do gosto, avançando sempre novas exigências quanto à boa forma ou segundo tradução do termo francês, à forma útil.

(...) A procura da boa forma visa todos os objetos de uso cotidiano, sejam eles os aparelhos domésticos, os móveis, ou utensílios da cozinha. N ão somente os artesãos como também os próprios artistas vêm se dedicando à pesquisa da forma e dos materiais mais adequados para exprimir a estética funcional do objeto. Entre os artistas que mais se tem destacado nesses últimos anos, encontra-se o finlandês Tapio W irkkala. Escultor sente-se, talvez por esta razão, atraído a observar e estudar a forma dos objetos de uso. Seus experimentos levam-no longe, num campo quase abstrato, onde não se cansa empregar os materiais mais diferentes. Seja na qualidade de desenhista, de artista ou de artesão, seja no mundo das formas dos organismos vivos, das cristalizações de minerais, ou na geometria descritiva. W irkkala parece sempre enraizado nos elementos de seu artesanato, isto é, seus voos imaginativos originam-se da própria matéria e do tratamento que dispensa a essa. W irkkala tem se salientado como um dos desenhistas mais versáteis e estimulantes da Europa, numa idade em que a industrialização leva, no conceito de muitos, a pensar com menor interesse no artesanato Mas com o vidro, a madeira os metais - principalmente a prata - W irkkala soube criar um mundo sereno e puro de formas precisas e ritmadas. (...) Seria isto possível entre nós, ou em países onde os artesãos e artistas não oficiais constituem uma classe marginal?"

Se, ao mesmo tempo, é clara a retomada aos conceitos proposto pela escola alemã, a Bauhaus, na busca de uma arte capaz de elimina barreiras tecnicistas, por meio da potencialização do projeto como pura ideação formal - posição também presente nas propostas do Museu - vale ressaltar que tal posicionamento não faz coro com a orientação racional-funcionalista, herdeira da Escola de Ulm, que definirá o modelo de ensino para o campo adotado na maioria das escolas de design brasileiras, sobretudo após a Fundação da Escola Superior de Desenho Industrial (ESDI), no Rio de Janeiro, em 1963.

No trecho anteriormente citado, ao destacar a produção de Wirkkala, há a critica à convicção pejorativa sobre os processos de produção artesanais face à atividade industrial. $\mathrm{O}$ texto encerra-se ao questionar sobre a possibilidade de aqui, no Brasil, desenvolverse uma experiência semelhante à finlandesa. Trata-se, portanto, d defesa do florescimento de um processo de produção industrial capaz de incorporar elementos materiais, culturais, sociais e tecnológicos próprios do contexto brasileiro sem perder de vista o debate internacional.

Este tema tem seus antecedentes no debate italiano à mesma época, sobretudo se considerada a origem de Pietro Mari Bardi e Lina Bo Bardi, ambos nascidos na Itália. Lina trabalhara com Gio Ponti na revista Italiana Domus. Gio Ponti, arquiteto designer italiano, iniciou sua carreira como diretor artístico numa tradicional indústria cerâmica italiana, o que influenciaria sua carreira de forma decisiva, sobretudo numa visão conciliadora das relações entre arte, artesanato e indústria. Argan, na mesma época, fez considerações importantes sobre o tema das relações entre 
arte, artesanato e indústria, utilizando-se também da produção de Wirkkala como resultado de uma evolução dos processos artesanais em direção aos processos industriais.

“(...) Se fala tanto da crise do artesanato: mas existe uma crise, uma condição de desaceleração também na indústria. A indústria, técnica produtiva típica da sociedade moderna guiada pela ciência moderna, é de fato enquadrada numa estrutura capitalista de exploração que limita conscientemente as possibilidades produtivas, no sentido qualitativo e por vezes também quantitativo, para alcançar fins particulares ou especulativos ao invés de fins sociais ou de progresso. Esta estrutura tende a manter bem clara a distinção entre direção e execução, reservando à primeira as funções ativas que, consideradas a partir de um ponto de vista estético, definem presunçosamente "criativas". Então, quando um Aalto, um A lbini, um W irkkala repensam, segundo novas meto dologias, um "tipo" de artesanato tradicional, pretendem demonstrar que a transformação do artesanato à indústria não deve ser alcançada a partir de uma "revolução da técnica", mas por meio da evolução da cultura técnica das classes que estavam tradicionalmente ligadas à produção concreta. Aqueles arquitetos vão afirmar que o design, como "contemplação produtiva", é produto de um Kunstwollen que não po de senão se explicar como expressão de umVolksgeist, e que, portanto, isso não é a arte da burguesia técnica, mas a verdadeira arte "popular" moderna. Por isso que o design, que reelabora industrialmente ou modernamente uma experiência do artesanato, pode realmente chamarse "design industrial"; enquanto que ao design americano, por exemplo, de umTeague, me parece mais apropriado o termo "design capitalista", ${ }^{10}$
A Itália foi um dos países que mais soube tirar proveito das atividades artesanais para o desenvolvimento da sua produção industrial. Segundo Argan, um país que em 1959 não possuía escolas de desenho industrial, mas escolas de $\operatorname{artesanato}^{11} \mathrm{e}$, que do ponto de vista do desenvolvimento industrial europeu, apesar de estar bastante atrás de seus vizinhos, conquista, ainda assim, uma posição de destaque no design a partir dos anos 1970. A posição de Argan revela-nos alguns dos pressupostos adotados para o desenvolvimento do desenho industrial na Itália. Reitera também uma postura crítica ao modelo norte-americano fortemente difundido nos países latino-americanos, inclusive no Brasil.

E a predominância do modelo de filiação modernista no País se dá pela adoção irrestrita do modelo de ensino racionalfuncionalista praticado pela escola suíça e, ao mesmo tempo, por uma prática formalista, relacionada à interpretação norteamericana do modernismo como linguagem estética mais eficaz para estabelecer diálogo com o desenvolvimento industrial, favorecida pela conjuntura econômica do País.

A polarização do mundo, a Guerra Fria e o fim da hegemonia europeia na condução do processo cultural ocidental levam os Estados Unidos não somente a exercer a hegemonia políticoeconômica como também uma hegemonia cultural sobre a Europa ocidental. No campo das artes visuais, há uma significativa mudança da estética oficial vigente até os anos 1930, nos Estados Unidos o realismo social, figurativista, confundia-se nas suas origens com o realismo socialista soviético e, diante da polarização, torna-se fundamental diferenciar-se de concepções estéticas semelhantes às adotadas pelo regime soviético.

Graças ao MOMA e a uma série de iniciativas internacionais intensifica-se a promoção do expressionismo abstrato como continuidade do modernismo, especialmente por meio das obras integrantes da escola de Nova York. Dessa forma, o abstracionismo é difundido e consagrado internacionalmente através da concessão de recursos públicos para a promoção de turnês internacionais 
e financiamentos norte-americanos destinados ao patrocínio de inúmeras instituições em todo o mundo voltadas à valorização da abstração como herdeira das vanguardas modernas. Entre elas estão, no Brasil, o Museu de Arte Moderna do Rio de Janeiro, criado em 1947, o Museu de Arte Moderna de São Paulo, fundado em 1948 e a Bienal de São Paulo, criada em 1951. ${ }^{12}$

Dessa forma, os Estados Unidos apropriam-se do projeto moderno, das propostas elaboradas pelas vanguardas europeias; dentro de uma perspectiva de modernização nem tanto cultural, mas, sobretudo, vinculada aos interesses desenvolvimentistas da nação. Dos anos 1930 aos 1950, grande parte do corpo docente oriundo da Bauhaus é acolhido pelas instituições de ensino norte-americanas. Dentro do contexto anteriormente descrito, de promoção de uma estética moderna e abstrata como estratégia de uma ofensiva diplomática cultural e econômica, a herança bauhausiana foi limitada às contribuições estético-projetivas o Estilo Internacional foi difundido e comercializado ainda que contraditório às premissas defendidas por Walter Gropius na fundação da escola na Alemanha, em 1919. ${ }^{13}$

"Diante de novas circunstâncias históricas, das exigências de um novo ambiente no qual os maiores expoentes do instituto eram estáveis, dos novos processos tecnológicos, às mesmas solicitações do público, desde já condicionado pela "cultura de massa" (a ascensão desta data do pós-última guerra), todos os componentes de design da Bauhaus são reduzidos somente à dimensão do "projeto", ainda que de grande relevo e de fato, jamais superado." ${ }^{14}$

A atribuição do primeiro prêmio da I Bienal InTERnACional DE SÃo PAULO à obra Unidade Tripartida, de Max Bill, elaborada partir de técnicas industriais e em aço inox, exibida na Exposição Max Bill no MASP, certamente fortaleceria, mais do que isso, orientaria a produção artística local a uma arte capaz de relacionarse com os materiais e processos pertinentes ao ambiente industrial.

No entanto, este ensaio pretendeu evidenciar que o debate acerca das linguagens modernistas presente no Museu por meio de suas exposições encontrava seus vínculos, não na formulação modernista de origem norte-americana, predominante entre nós, cuja ênfase recai sobre a manipulação estrita de um vocabulário formal e nem mesmo na radicalidade das propostas racional funcionalistas da Escola de Ulm; mas na utopia moderna da Bauhaus, numa abordagem ampliada do fazer artístico, das relações entre arte e design e, sobretudo, nas ideias presente no debate italiano, nas palavras de Argan, ${ }^{15}$ na defesa da evolução da cultura técnica das classes tradicionalmente ligadas à produção como perspectiva para o desenvolvimento da sociedade em todos os seus aspectos.

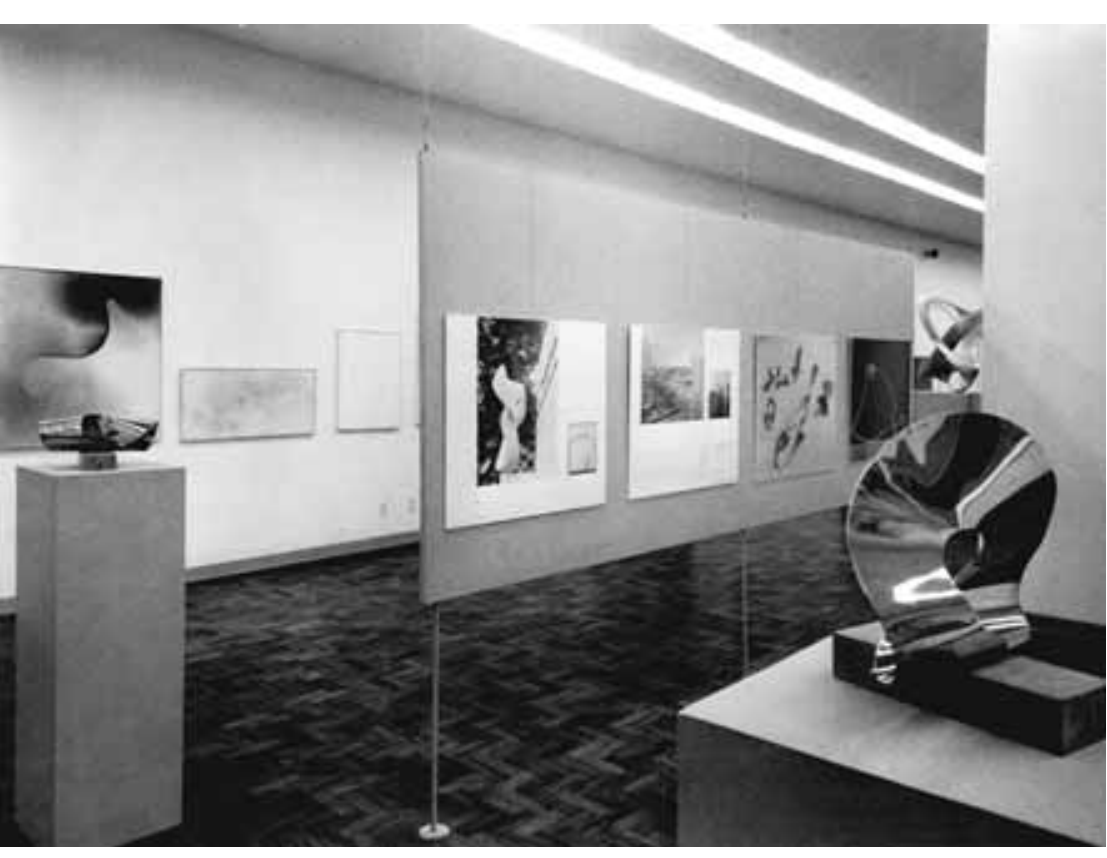
36 Expo siç̄o Max BILL 195
Biblioteca e Centro de Documentaç̃ão do MAS 


\section{N OTAS}

1. As relações entre o discurso abstracionista no Brasil e o desenvolvimento do campo do design no País foram também amplamente discutidas pela autora em dissertação de mestrado e livro publicado. Ver: CARA, Milene. Do Desenho Industrial ao design no Brasil: uma bibliografia critica para a disciplina. São Paulo: Blucher, 2010.

2. AMARAL, Aracy. Surgimento da abstração geométrica no Brasil. In: AMARAL, Aracy. Arte Construtiva no Brasil. AMARAL, Aracy (org.). São Paulo: Companhia Melhoramentos; São Paulo: DBA Artes Gráficas, 1998. (Coleção Adolpho Leirner) p.29-46.

3. Idem. p.29-46

4. Idem. p. 46-53

5. Idem. p. 46-53.

6. Segundo Leite, o arquiteto Jacob Ruchti, suíço de nascimento, além de ser a grande revelação construtiva no III Salão de Maio, de 1939, tem significativa importância para a implantação da primeira experiência de raízes modernistas voltada para o ensino das artes. In: LEITE, João de Souza. De costas para o Brasil. 0 ensino de um design internacionalista. In: MELO, Chico Homem de. 0 design gráfico brasileiro: anos 60; Chico Homem de Melo (org.) São Paulo: Cosac Naify, 2006. p.257-8.

. No Museu de Arte - Próxima Exposição Didática da História Das Artes Gráficas. Diário da Noite, 25 de junho de 1949.

8. CARA, Milene. Do Desenho Industrial ao design no Brasil: uma bibliografia critica para a disciplina. São Paulo: Blucher, 2010.
9. Formas. Habitat (50):40-1, set./out.1958

10. ARGAN, Giulio Carlo. Arte,Artigianato, Industria. In: Proggetto e 0 ggetto. Milano: Medusa, 2003.

11. ARGAN, G. C. Risposta a um'inchiesta sull'artigianato. In ARGAN, G. C. Progetto e 0 ggetto. Milano: Medusa, 2003. p. 46.

12. ARGAN, G. C. Progetto e Oggetto. Milano: Medusa, 2003

13. As contribuicões históricas citadas em texto foram proferidas em palestra - Abstração e Política Hegemônica dos Estados Unidos - de Felipe Chaimovitch, durante a disciplina de pós-graduação do Curso Interunidades em Estética e História, em 03 de novembro de 2005, no Museu de Arte Contemporânea (MAC), localizado na Universidade de São Paulo.

14. CARA, Milene. Do Desenho Industrial ao design no Brasil: uma bibliografia critica para a disciplina. São Paulo: Blucher, 2010

15. FUSCO, Renato de. Storia D el D esign. Bari, 1985. p.150-153

16. ARGAN, G. C. Progetto e 0 ggetto. Milano: Medusa, 2003 

de produtos industriais, quanto de design gráfico - intensifica-se, sobretudo, a partir do início da década de 1970, não somente pelas novas relações estabelecidas pelo museu, mas também favorecidas pela própria conjuntura política do País. ${ }^{1}$

A política industrial adotada desde o governo Juscelino Kubitschek foi fundamental para o início do processo de industrialização brasileira, ainda que seus desdobramento revelassem a ausência de uma melhor articulação social. O desenvolvimentismo promovido por Juscelino encerrar-se-ia em 1961, em meio a uma crise: altos déficits governamentais e crescente aumento da inflação. Jânio Quadros toma posse em 1961 e no mesmo ano renuncia, numa estratégia política desastrosa, abrindo espaço para a posse de João Goulart, vice-presidente de Jânio.

As medidas tomadas por Goulart - reforma agrária, ampliação dos direitos políticos, ampla intervenção estatal na economia, nacionalização de empresas e rigorosa regulamentação de remessas de lucro - desagradaram os setores mais conservadores da sociedade brasileira e, somadas ao contexto de Guerra Fria, na qual a vitória da revolução cubana no continente americano acirrava o temor ao avanço do comunismo, culminaram no golpe militar em 1964, no País.

O regime militar, por meio dos Atos Institucionais (AI) garantia amplos poderes aos seus dirigentes por meio da violenta repressão aos opositores, e facilitaria a atuação do governo em áreas estratégicas, garantindo resultados favoráveis à economia do País. O Programa de Ação Econômica do Governo (PAEG), elaborado pelos ministros Roberto Campos e Otávio Gouveia de Bulhões, estimularia as exportações não apenas de recursos naturais, mas também de produtos manufaturados, suscitando debates dentro do design no País. O empecilho foi que, ao favorecer a inserção de produtos brasileiros no mercado internacional, a produção brasileira, acostumada a recorrer aos modelos internacionais, pouco tinha a oferecer além de cópias mal elaboradas de produtos já conhecidos nos países desenvolvidos.
Agravando a situação, a substituição de importações não exigiu a absorção e desenvolvimento de tecnologia, resultando no desenvolvimento de uma indústria com elevado grau de ineficiência, não-competitiva interna e internacionalmente com pouca ou nenhuma criatividade em termos tecnológicos. A política protecionista adotada e o modelo de substituição de mportaç̃es, fundamentado na inserção de indústrias estrangeira para a formação do parque industrial brasileiro, contribuíra para a formação de uma mentalidade empresarial protecionista no país - na qual os empreendedores industriais não encararam o protecionismo como um meio para que, num determinado tempo, se implantasse uma indústria eficiente e competitiva; mas como um fim -o que garantia um mercado interno sem concorrência e, portanto, sem necessidade de investimentos para o desenvolvimento de novas tecnologias. ${ }^{3}$

Com a garantia de um mercado interno de consumo, a maioria das empresas estrangeiras atraídas para o país consolidou, no Brasil, estruturas industriais obsoletas, já superadas em seus países de origem, contribuindo para um fraco desenvolvimento tecnológico e criativo no campo da produção industrial brasileira. São, portanto, estas diretrizes político-econômicas, adotadas no período, que ambém estimularão as primeiras reflexões sobre a necessidade da consolidação de um design brasileiro autônomo e competitivo nos contextos nacionais e internacionais.

"O período do chamado "milagre" estendeu-se de 1969 a 1973, combinando o extraordinário crescimento econômico com taxas relativamente baixas de inflação. (...) 0 milagre tinha uma explicação terrena. $0 \mathrm{~s}$ técnicos que 0 planejaram, com Delfim $\mathrm{N}$ etto à frente, beneficiaram-se, em primeiro lugar, de uma situação da economia mundial caracterizada pela ampla disponibilidade de recursos, 0 s países com desenvolvimento mais avançados aproveitaram as novas oportunidades para 
tomar empréstimos externos. 0 total da dívida externa desses países, não produtores de petróleo, aumentou de menos de 40 bilhões de dólares, em 1967, para 97 bilhões, em 1972, e 375 bilhões, em 1980". ${ }^{4}$

O "milagre", no entanto, apresentava também suas fragilidades e deficiências: realizava-se à custa de uma excessiva dependência do sistema financeiro e do comércio internacional. Do ponto de vista social, a política econômica privilegiou a acumulação de capital através dos subsídios e favorecimentos apontados e em contrapartida, os índices de ajustes salariais estavam muito aquém daqueles registrados pela inflação.

Em outubro de 1973, ocorreu a primeira crise internacional do petróleo. Em 1975, é lançado o II Plano Nacional de Desenvolvimento (PND). O I PND fora elaborado por Roberto Campos em 1967, cujo objetivo concentrava-se no reequilíbrio das finanças e no combate à inflação.

"Com o II Plano Nacional de Desenvolvimento (PND), em 1975/79, o Estado articulou uma nova fase de investimentos públicos e privados nas indústrias de insumos básicos (siderurgia e metalurgia dos não-ferrosos, química e petroquímica, fertilizantes, cimento, celulose e papel) e bens de capital (material de transporte e máquinas e equipamentos mecânicos, elétricos e de comunicações), além de investimentos públicos em infra-estrutura (energia, transportes e comunicações). 0 objetivo foi o de completar a estrutura industrial brasileira e criar capacidade de exportação de alguns insumos básicos. (...) Dessa forma, em fins da década de setenta e princípio dos anos oitenta, a estrutura da indústria brasileira já estava praticamente completa. A formação dessa estrutura, sob um esquema de substituição extensiva de importações e, subsequentemente, de promoção de exportações, foi fortemente induzida pelo Estado através de políticas de proteção (tarifa aduaneira, barreiras não-tarifárias, política cambial e regulação do investimento) e de promoção (incentivos fiscais e crédito subsidiado). Embora tenham sido eficazes na construção de uma base industria integrada e altamente diversificada, essas políticas deixaram sequelas, pois, ao perseguirem um objetivo de "estrutura industrial completa" sob um elevado e permanente esquema de proteção e promoção, geraram ineficiências em nível de indústrias específicas, em prejuízo da especialização e da maior integração com o mercado internacional. 0 resultado é que a economia brasileira tornou-se extremamente fechada, apresentando um dos menores coeficientes de importação do mundo. Em consequência, muitas indústrias permaneceram não-competitivas, tanto no mercado interno quanto no mercado internacional." 5

Quanto à abertura política, em 1978, o governo iniciou encontros com líderes da oposição e da Igreja, concorrendo para a restauração das liberdades públicas. Em 1979, o AI - 5 é revogado e restauram-se os direitos individuais e a independência do Congresso. No mesmo ano, subiria ao poder o general João Batista Figueiredo cujo governo combinaria dois aspectos críticos a permanência da ditadura militar: a ampliação da abertura política e o aprofundamento da crise econômica. O segundo choque do petróleo impõe maiores dificuldades ao balanço de pagamentos, a subida crescente das taxas internacionais de juros e a dificuldade em obter empréstimos lançam o país em um período de grave recessão: pela primeira vez desde 1947, os indicadores do produto Interno Bruto (PIB) foram negativos. Dentre os setores mais atingidos estão as indústrias, concentradas nas áreas urbanas, oque, consequentemente, resultou em elevados níveis de desemprego determinando grandes contingentes populacionais marginalizados tanto do ponto de vista do trabalho como do consumo. 
A situação social, política e econômica brasileira impõem ao design significativas consequências ao seu desenvolvimento. A aposta do Estado no processo de avanço e consolidação de uma base industrial por meio de isenções ou reduções de taxas, financiamentos com juros baixos e incentivos fiscais, somada ao incentivo à exportação - possível graças à concessão de empréstimos, anulação ou redução dos impostos vigentes desvalorização cambial - inauguram um período de inúmeros debates nos quais o design passa a ser, na maioria deles, encarado como uma prioridade para o país.

É esse o ambiente que favorecerá uma extensa sequência de exposições dedicadas à apresentação da produção industrial de diversos países, a primeira delas em 1965, a exposição DESENHO InDUSTRIAL Sueco, na qual 10 vitrines com artefatos industriai são exibidas no Museu, após a passagem da mesma pelo Rio de Janeiro. Mas é, sobretudo, na década de 1970, que o debate se intensifica com exposições dedicadas ao tema quase que ano a ano. Em 1970, é apresentada a exposição Desenho IndUSTRIAL DA Escandinávia, em 1973, Desenho Industrial da Argentina, em 1974, A IDEIA BraUn. Há ainda o registro das exposições Tempo dos Modernistas e Bauhaus no mesmo ano, porém no arquivo histórico do museu não existem documentos das duas últimas, à exceção de imagens. Em 1975, seria a vez do design italiano, com a exposição Desenho Industrial Italiano; Desenho Industrial FINLANDÊs, em 1976; a exposição Firma ItÁlIA - ARTE, CINEMA, GRÁFICA, PUBLICIDADE, TELEVISÃO E COMUNICAÇão INDUSTRIAI ITALIANA aconteceria em 1977. Em 1978, a Exposição DE MóveIs INNOVATOR e, já na década de 1980, as exposições: ITÁLIA - UM PAÍs MODELADO PELO HOMEM, A ARTE DO AUTOMÓVEL, EXPOSIÇão DE Design FinlandÊs e a importante exposição Produto - Forma - História - 150 ANos De Design Alemão, realizada em 1988.

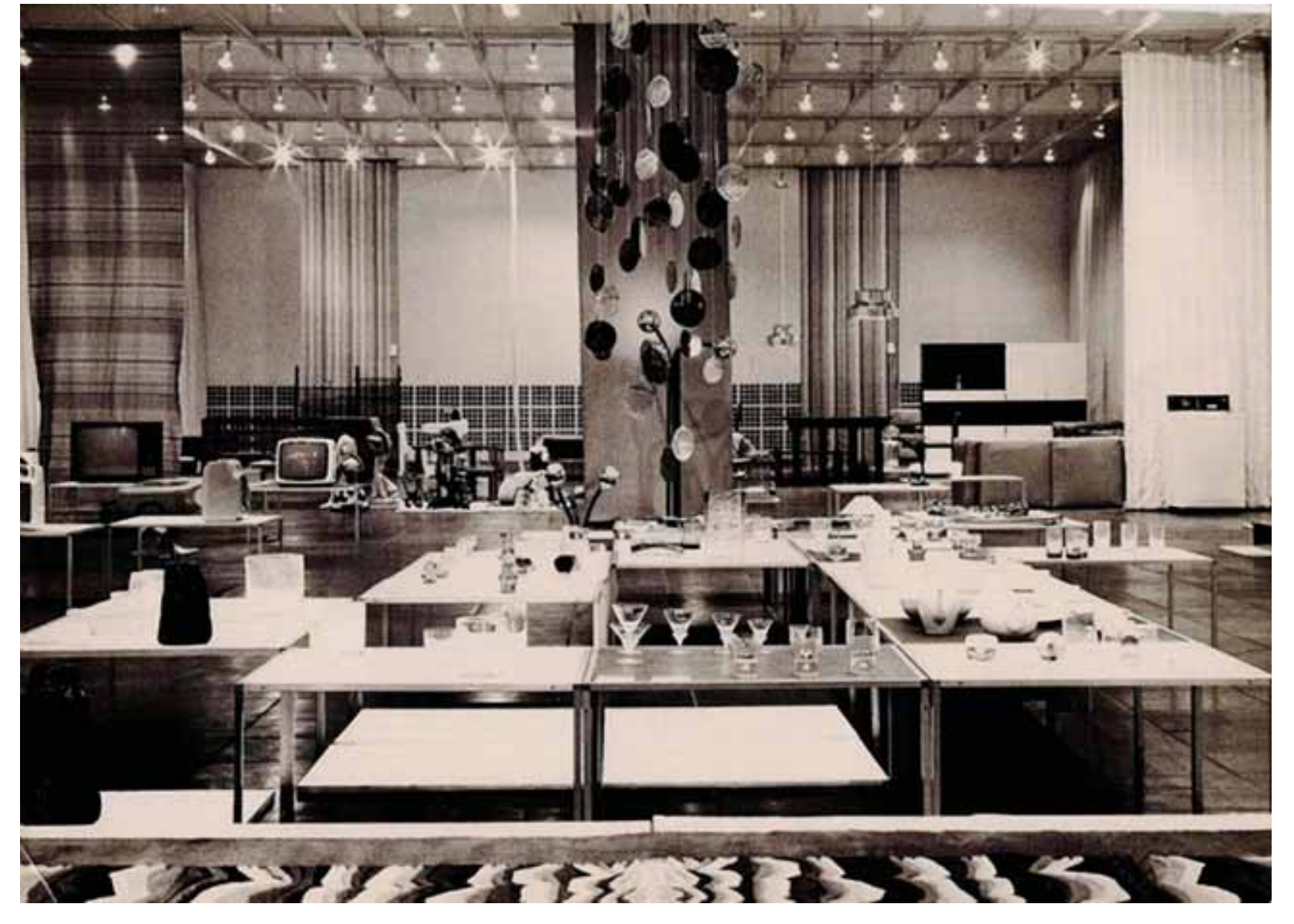

A presença da maioria delas no Museu está associada ao patrocínio ora da $\mathrm{ABDI}$, do intercâmbio com o MAM - RJ, ou ao patrocínio de embaixadas e de indústrias presentes no País, ou ainda, inaugurando suas atividades por aqui. O objetivo dessas exposições não só é o aprofundamento da reflexão em torno da mportância do desenvolvimento do produto industrial brasileiro com vistas ao processo de industrialização acelerada na qual o país estava imerso, mas a tentativa de conscientização por parte do empresariado nacional acerca da importância do design como elemento central para o desenvolvimento da produção nacional. 
E neste período que o debate acerca do design no País ganha dois pólos de significação: o primeiro deles, o entendimento do design somente enquanto elemento estratégico, Know-how ou conhecimento capaz de garantir o desenvolvimento de produtos mais adequados às necessidades do consumidor e do mercado. $\mathrm{O}$ outro, na qual o design se apresenta com um caráter mai complexo e interdisciplinar, também como elemento fundamental para o desenvolvimento, mas onde fatores como tecnologia, razão e precisão também devem entrosar-se com o comportamento humano e as aspirações sociais de uma coletividade.

Ambos os aspectos estarão presentes nas exposições realizadas no Museu, seja nas dedicadas à apresentação da produção internacional ou nas dedicadas à exibição da produção nacional.

Em menor número, as primeiras exposições dedicadas à produção nacional são, sobretudo, às relacionadas ao mobiliário brasileiro Fato já conhecido, é a demanda imposta pela arquitetura moderna que reconfiguraria primeiramente a produção de mobiliário, na busca de uma linguagem em consonância com as novas orientações presentes nos projetos arquitetônicos.

Em 1971, ocorre no Museu a exposição MobILIÁrIo BrasileIroPremissas e Realidade, no mesmo ano, é realizada a retrospectiva WARCHAVCHIK E AS ORIGENS DA ARQUITETURA MODERNA NO BRASI dedicada à obra do arquiteto, que também exibiria o mobiliário desenvolvido por ele, uma vez que o mercado nacional não oferecia móveis modernos para as suas primeiras residências modernistas. Em 1975, é organizada uma retrospectiva da obra de Lívio EDMONDO LEVI, arquiteto e designer, que falecera prematuramente em 1973, cuja atuação como designer se desenvolveu, sobretudo, no campo joalheiro e luminotécnico. Em 1977, ocorreria ainda a exposição Origens da Industrialização em São Paulo, parte do projeto de pesquisa Imagens e História da Industrialização em São Paulo, cujo objetivo era contar com o apoio da sociedade para a reunião de documentos e imagens que contribuíssem para a preservação da memória do processo industrial

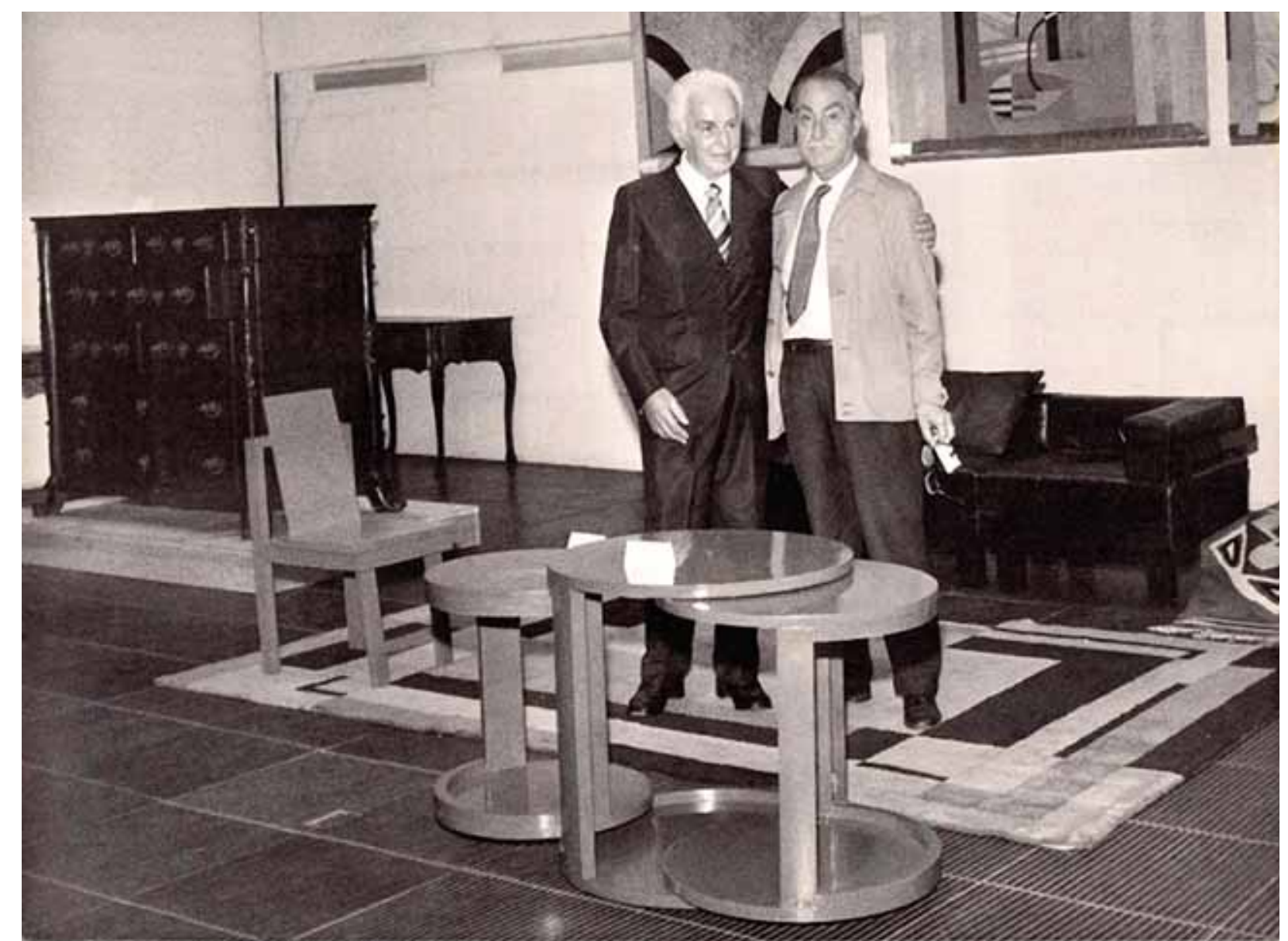

E em 1981, era realizada a exposição Pesquisa de QuALIDAde: o Terminal da Caixa em Tempo Real, na qual o escritório Cauduro e Martino apresenta o projeto Terminal de Caixa em Tempo Real, primeira expressão nacional da utilização de equipamentos eletrônicos no processamento de dados do sistema bancário. $\mathrm{O}$ terminal, uma máquina autenticadora ligada a um computador em tempo real, era capaz de realizar um elevado e complexo conjunto de funções.

Em 1989, a exposição Mostra do Produto Brasileiro:

39 Expo siçäo Mobllário BrasillerRo - Premissas e RealdoAde 1971 Biblioteca e Centro de da FIESP/CIESP, com apoio do INPI, tinha como objetivo promover tanto a importância do desenvolvimento da tecnologia no país, 
como o papel do design enquanto componente fundamental do processo tecnológico. Ambas as exposiç̃es eram formas de demonstração da capacidade e importância do design à indústria brasileira, na medida em que a disciplina se configurava cada vez mais como um instrumento de negócios traduzido em qualidade do produto.

É, portanto, este o contexto do País e a contribuição do Museu por meio de suas exposições ao debate da produção nacional. E como forma de evidenciar esta contribuição elegeu-se as exposições: Desenho IndUSTRIAL DA EsCANDINÁviA, realizada em 1973; e a exposição Produto - Forma - História - 150 ANOS DE Design Alemão, apresentada em 1988, dentre as mostras dedicadas à exibição da produção de design internacional que serão discutidas a seguir com maior aprofundamento, seja pela capacidade de síntese em relação às temáticas também recorrentes às demais exposições, seja pela riqueza da documentação presente no acervo do Museu.

Das exposições dedicadas à produção nacional, duas delas são fundamentais: a exposição Mobiliário Brasileiro - Premissas E Realidade, realizada em 1971, e a exposição Mostra do Produto Brasileiro: design e tecnologia, apresentada em 1989. Ambas em momentos distintos da história do Museu e da história brasileira: a primeira, no início da intensificação dos debates ao tema, apresenta farto material. A outra, já em 1989 e com escasso material localizado no acervo do Museu, foi composta pela exibição de peças inscritas pelas próprias empresas e designers e tinha como objetivo a promoção do design como elemento fundamental para o desenvolvimento da produção nacional. O ano de 1989 é também o último da gestão de Pietro Maria Bardi na direção do Museu e encerramento de uma década na qual a sucessão política do País e as profundas mudanças econômicas a partir dos anos 1990 determinariam ainda novos rumos à discussão acerca do papel da disciplina no Brasil. O texto a seguir dedicarse-á a apresentar três das exposições acima citadas, não somente em virtude da importância de cada uma delas, como também pela disponibilidade de acesso a fontes seguras dos eventos.
DESENHO INDUSTRIAL DA

ESCANDINÁVIA

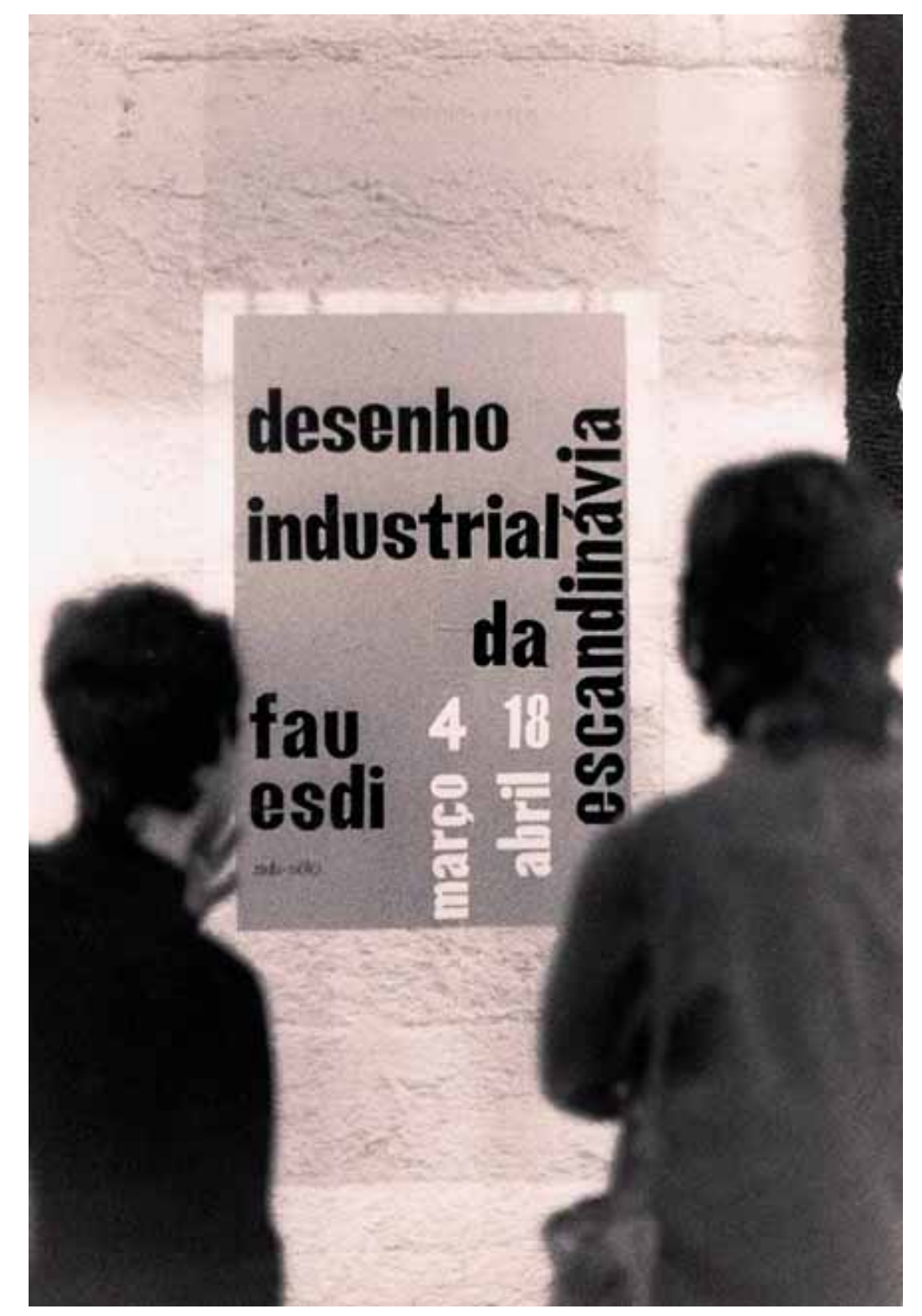

40 Expo sição Desenho IndustriaL DA EscandináVIA 1971 Documentação do MASP 
A exposição Desenho Industrial DA Escandinávia, realizada em março de 1971, no MASP, fora organizada pelos arquitetos suecos Jan Dranger e Johan Huldt, por ocasião da II BIENAL DE Desenho Industrial, realizada no Museu de Arte Moderna no Rio de Janeiro (MAM - RJ) em 1970 e, provavelmente, seguiria a São Paulo, para exibição no Museu. Carmem Portinho, à época diretora da Escola Superior de Desenho Industrial, solicita a Bard que a mostra brasileira, que incluía a representação da ESDI, fosse também exibida em São Paulo, dada a importância da cidade como centro industrial.

\section{Prezado Bardi,}

Como é de seu conhecimento, a II Bienal Industrial de Desenho Industrial acaba de ser inaugurada no MAM, com uma parte nacional e outra estrangeira. Ambas as representações são muito interessantes, principalmente a mostra da Escandinávia. A mostra brasileira inclui uma parte da ESDI que foi toda programada e executada aqui na Escola com orientação de nossos professores.

Em nossa representação está fazendo tal sucesso que os arquitetos suecos que vieram montar a expô da Escandinávia pediram para levá-la posteriormente para a Suécia a fim de ela percorrer os demais países escandinavos. Entretanto, nós da ESDI, preferíamos que ela fosse exposta em São Paulo que é nosso maior centro industrial.

Venho pois consultar-Ihe sobre a possibilidade de, juntamente com a exposição da Escandinávia, expor aí em São Paulo a parte brasileira ou pelo menos a mostra da ESDI que está muito interessante.
Muito the agradeceria uma resposta breve para organizarmos nosso programa antecipadamente.

Muito Ihe agradeço.

\section{Cordialmente,}

Carmem Portinho, Diretora

Se o catálogo da exposição e a fortuna crítica não relatam a participação da mostra brasileira, as imagens localizadas no arquivo do Museu confirmam a presença dos trabalhos da Escola Superior de Desenho Industrial (ESDI) e da Faculdade de Arquitetura e Urbanismo da Universidade de São Paulo (FAUUSP) conjuntamente com a mostra dos produtos escandinavos.

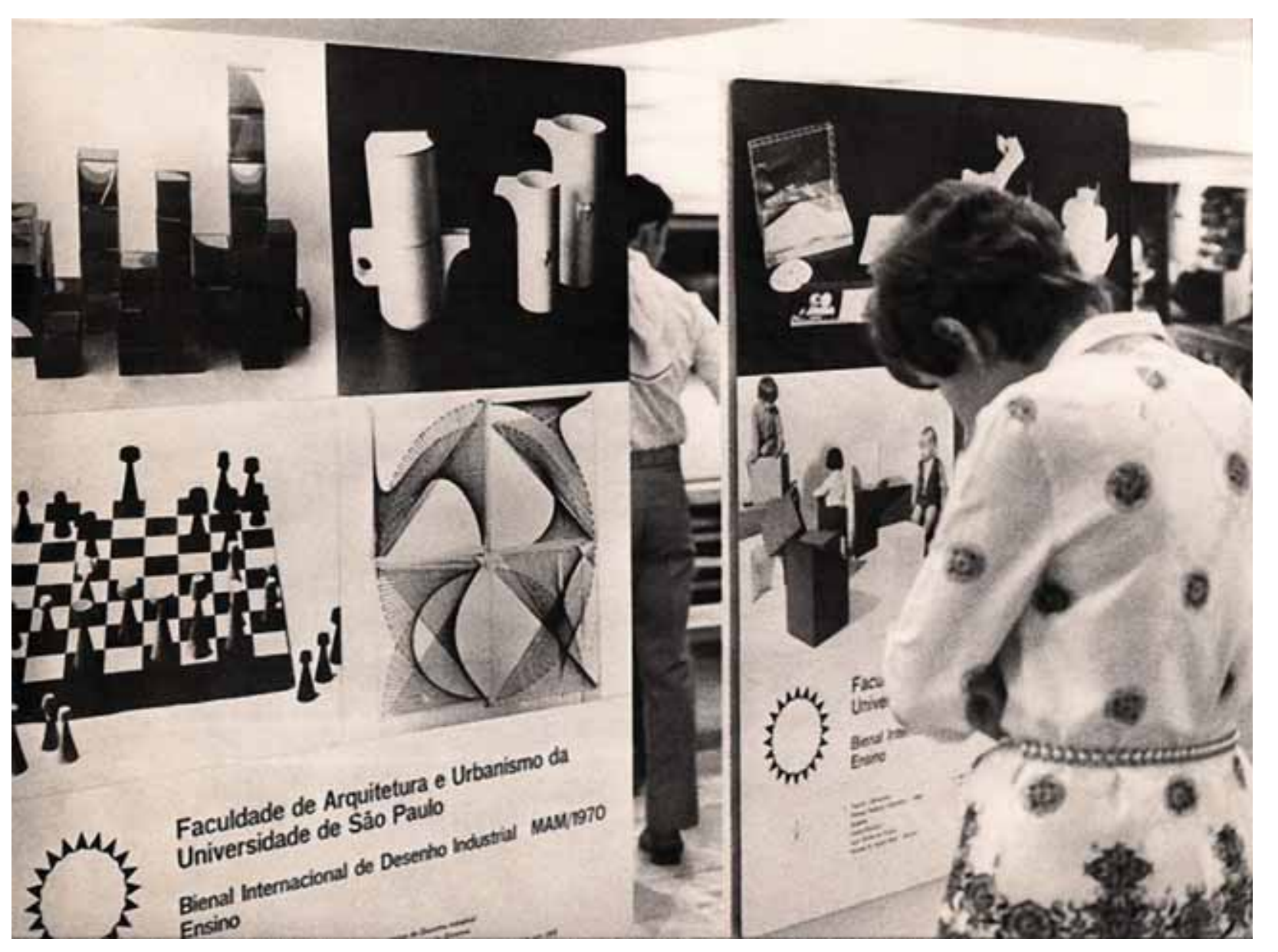

41 EXPo SIÇÃO D ESENHO IndUSTRRAL DA ESCANDINÁVIA 1971
Biblioteca e Centro de Documentação do MASP 


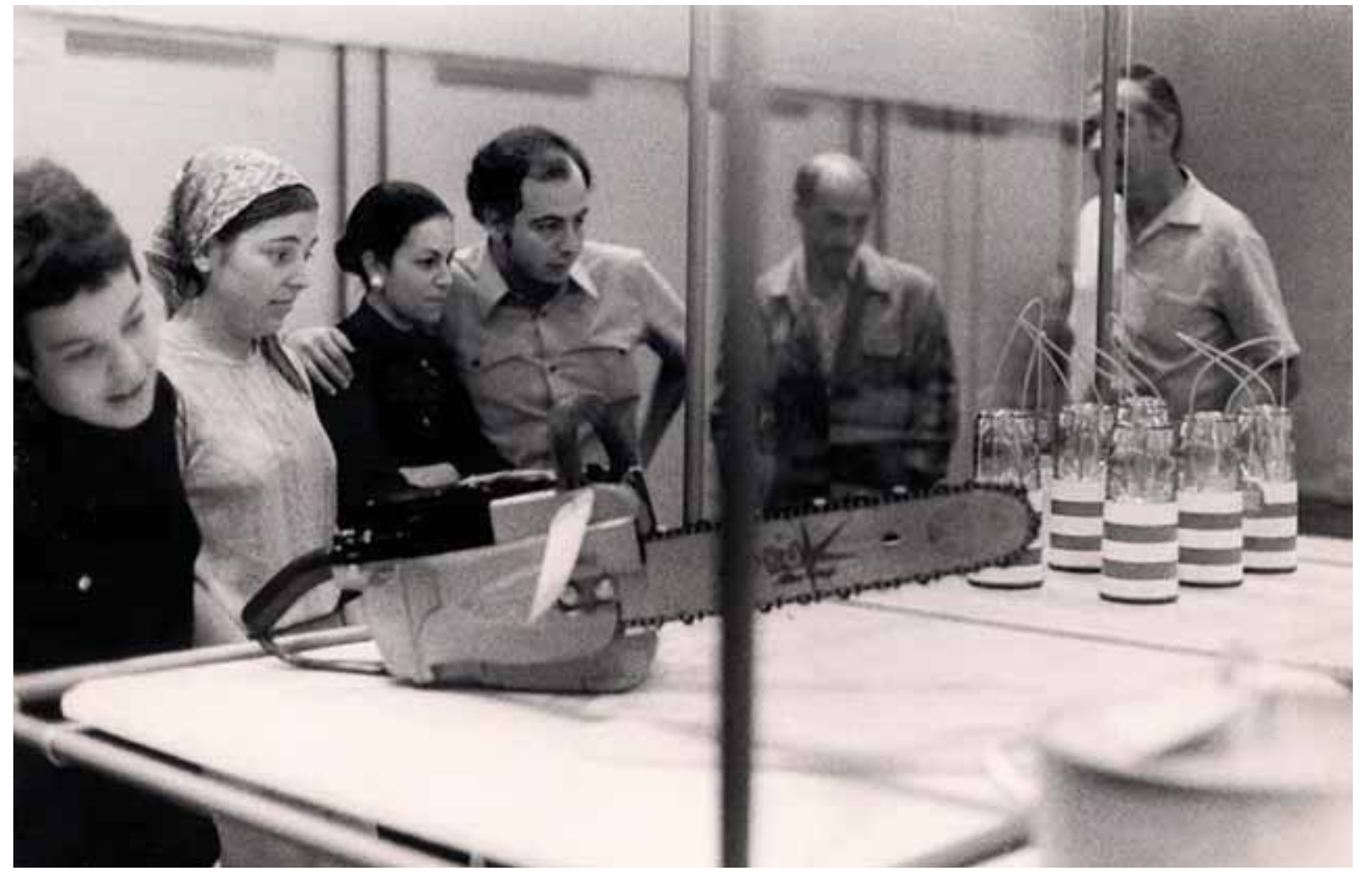

Em continuidade com o debate proposto pela II Bienal de Desenho Industrial, a mostra, organizada com a colaboração de instituições representantes dos países Escandinavos, tinha como objetivo demonstrar, às indústrias paulistas, um modelo de alta qualidade da produção industrial, similar ao que já se encontrava nos tradicionais campos da produção escandinava. Ainda que no Brasil já existissem uma série de empresas com concessões para a produção de originais suecos, a mostra procurava, a exemplo da experiência escandinava, estimular o desenvolvimento de uma cultura produtiva baseada nas necessidades regionais e não no aproveitamento de originais externos, abrindo também mercado de trabalho aos designers formados pelas instituições brasileiras, que à época, encontravam grandes dificuldades de inserção profissional. E Bardi, no texto de abertura do catálogo da exposição, é quem faz 42 EXPO SIÇAO DESENHO DA ESCANDINÁVIA 1971
Biblioteca e Centro de Documentação do MASP
"A realização da exposição "D esenho Industrial Escandinavo" oferece-nos a oportunidade para relembrar um dos tantos fatos que, durante os vinte e quatro anos, se desenvolveram neste Museu, fundado pelo grande e inesquecível brasileiro Assis C hateaubriand. Há vinte anos inauguramos a primeira escola de "industrial design": 0 Instituto de Arte Contemporânea, nos moldes mais convenientes, com vinte vagas, dos aprovados cinco eram bolsistas de outros estados. 0 curso desenvolveu-se com resultados altamente positivos tendo alguns alunos terminado seus estudos na Escola de U Im, dirigida por Max Bill que, nesse tempo, realizava no Museu sua primeira exposição fora da Suíça. Sempre foi nosso princípio lançar ideias e indicar os caminhos técnicos para uma cidade com milhões de habitantes e bastante dinâmica, para que outros seguissem o exemplo. Formamos também a primeira escola de propaganda, hoje com vida própria e sempre progredindo, o primeiro curso de cinema; um curso para a formação de professores de desenho onde, ao lado do ensino do desenho matemático, se desenvolvia o ensino do desenho da história da arte, sociologia, psicologia etc.; a primeira orquestra sinfônica juvenil e outras inúmeras iniciativas, sempre pioneiras, essa era a tarefa de uma célula museográfica ativa e nova.

Infelizmente, quando transferimos, generosamente, todos os cursos, já estruturados e em pleno funcionamento, a outra instituição, tudo foi por áqua abaixo. São Paulo, capital da indústria latino-americana, ainda espera por sua escola de "industrial design". O Museu não se furtará em participar de todas as iniciativas neste sentido e apoiará todas as manifestações "a latere" da arte-arte. Eis que, após a exposição "História em Q uadrinhos" abrimos a sala para a do "D esenho IndustrialEscandinavo" arespeito daqual seriasupérflua 


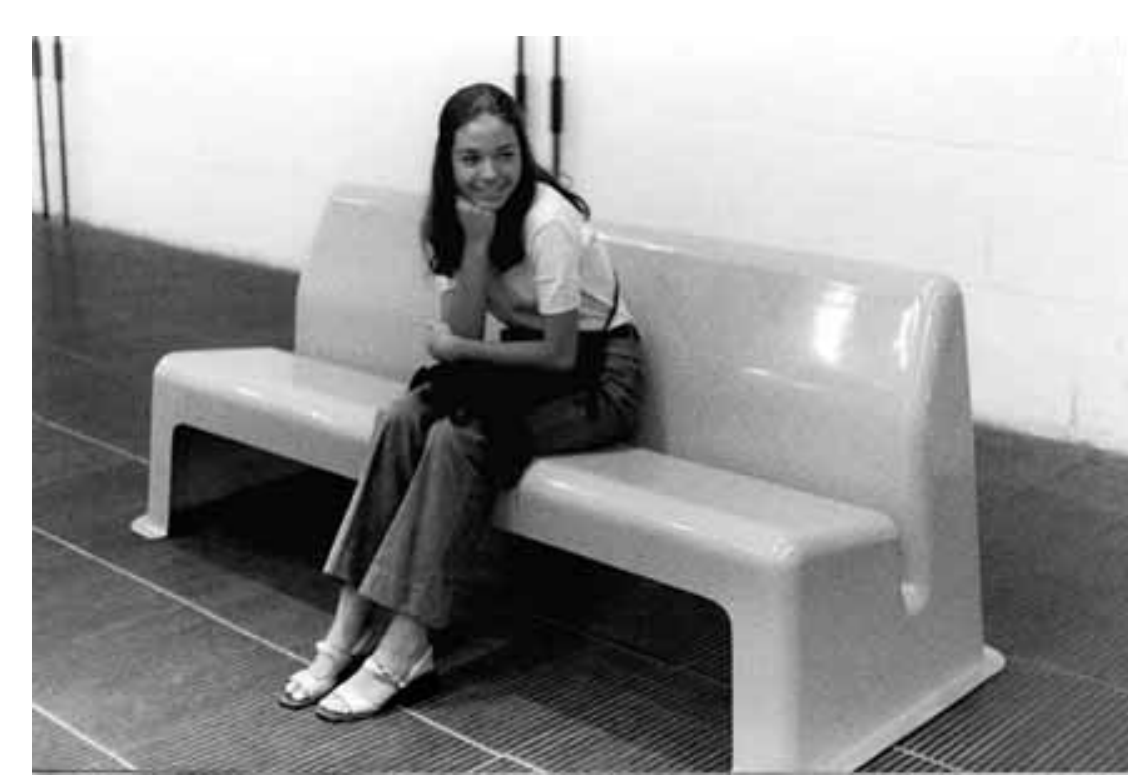

De alguma forma, o texto de Bardi, bem como o papel do Museu em acolher propostas expositivas oriundas de diversas instituições não revelam o mesmo entusiasmo dos primeiros anos da fundação do Museu. O MASP, que inovara numa série de iniciativas para o campo do design, certamente ressente-se da morte de seu fundador Assis Chateaubriand no apoio às iniciativas e, em parte, transmitira a outras instituições o papel de promotor de uma cultura de design no País. À exceção de um discurso do qual o Museu não se furtará em defender por meio de suas atividades e que será ainda tema 44 Bauhaus e o Tempo dos Centro de Documentação do MASP.
A exposição Produto - Forma - HistóRIA - 150 ANOS DE Design Alemão, realizada de novembro de 1988 a janeiro de 1989, no Museu, teve conceituação didática de Heinz Fuchs, François Buckhardt e montagem e organização orientadas pelo professor Kar George Bitterberg, da Escola Superior Técnica de Stuttgart, fruto de uma iniciativa do Instituto de Relações Exteriores de Stuttgart, que ja organizara a exposição Bauhaus, realizada no Museu, em 1974 e da qual somente as imagens presentes nesse texto foram localizadas no arquivo histórico do MASP . No Brasil, a mostra foi promovida pelo Instituto Goethe, com o apoio do Consulado Geral da República Federal da Alemanha e empresas multinacionais de origem alemã instaladas no País e, depois de São Paulo, seguiria ao Rio de Janeiro.

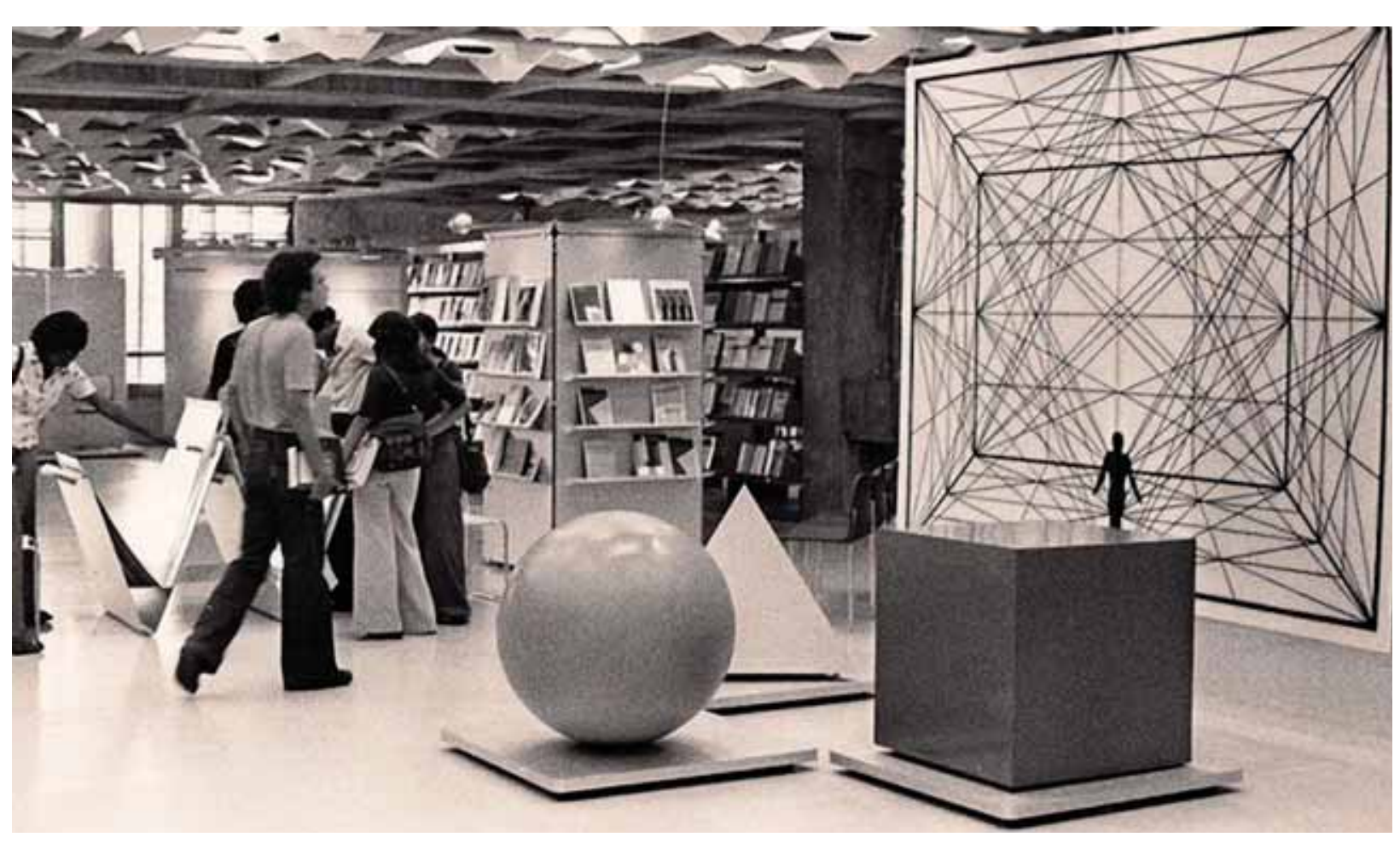




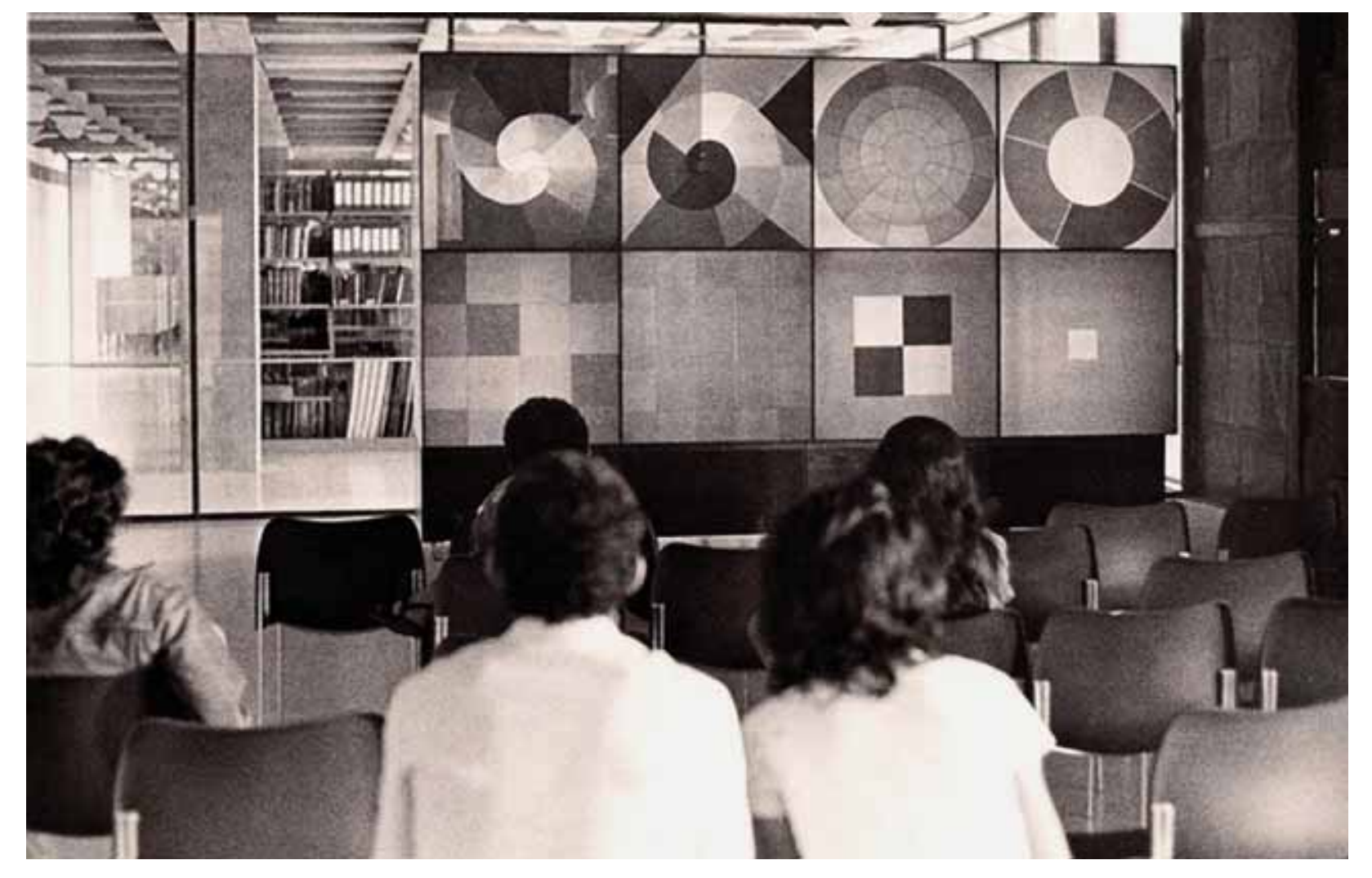

A mostra teve como objetivo fornecer um resumo históricocultural do design e da Alemanha ao longo de 150 anos, de 1820 a 1980, por meio da reunião de 200 objetos originais e farta documentação fotográfica. Em entrevista à época , Bitterberg frisou ser o design alemão uma das expressões maiores da cultura em seu país. Ainda segundo o professor, o designer alemão é essencialmente individualista, faltando um trabalho coletivo para que a vanguarda floresça e comentou o grande apoio que a área recebe no País das instituições culturais alemãs, por meio de cursos, palestras, seminários e concursos de produtos.

Ocupando aproximadamente mil metros quadrados no Museu, a mostra foi dividida em sete períodos históricos que marcaram cultura alemã: o primeiro deles, a Restauração Biedermeier 1820Centro de Documentação do MA
(1900); Os anos 1910 - 1933, Objetividade no Terceiro Reich, Classicismo 1933-1945, A Reconstrução - O Novo Design 1948 1962 e Ideias Novas - Fim do Funcionalismo? 1970 - 1980.

A proposta expositiva, além de oferecer um amplo panorama do design alemão, antecipa uma reflexão que estará presente, muito anos depois, no debate da disciplina no Brasil: a consideração de produtos produzidos, no caso alemão, antes da segunda metade do século XIX como design. Ou seja, a exibição desses exemplares é uma forma de mostrar a importância da atividade não somente como arte, como também elemento importante do registro da cultura de uma determinada época, reflexo da multifacetada complexidade, desejos e atitudes de uma sociedade.

Esta compreensão, que se afasta de um entendimento do design enquanto disciplina estritamente vinculada ao processo de industrialização, vai ao encontro da concepção que o Museu, desde o início de suas atividades, tem para a arte e para o design: manifestações que se dão como consequência do meio, como resposta às condições técnicas, históricas e estéticas de uma determinada cultura em espaço e tempo específicos.

“(...) À tradicional questão de que seria errado considerar o que era produzido antes da metade do século XIX como design, uma vez que, como escola, ele não existia inicialmente, - catálogo completo e bem ilustrado já esclarece que a qualidade do que era projetado na época permite hoje que essa designação não seja tão fora de propósito. Arquitetura mobiliário, peças utilitárias, produtos industrializados estes mais para a metade do século passado - e exemplos de desenho gráfico estão na exposição para mostrar a importância dessa atividade não só como arte (o que muitos designers até considerariam uma ofensa), mas como elemento importante no registro da cultura de determinada época. Fica claro, em cada segmento da exposição, que a produção 
de uma época está tão condicionada ao comportamento da sociedade quanto o pensamento ou as artes plásticas." ${ }^{12}$

E corroborando não somente esta hipótese, bem como reforçando a influência da escola alemã, a Bauhaus, para a experiência promovida pelo MASP nos seus primeiros anos, Pietro Maria Bardi redige um texto dedicado a relatar esta influência em sua coluna na revista Isto é, Senhor, por ocasião, da exposição Produto - Forma - História - 150 Anos de Design Alemão:

“(...) Parece-me, então, que vale a pena recordar a primeira Escola de Design aberta no Brasil, na época da criação do Instituto de Arte Contemporânea, uma seção do MASP que, ao redor da Pinacoteca, funcionava como órgão ativador de todos os setores da arte. Era uma retomada, em termos mais modernos, do esquecido e consistente empenho definido pela Semana de Arte Moderna de 1922

Entre as várias tentativas de inovar, uma das primeiras foi dar atenção ao design. De acordo com 0 mágico fundador do MASP, Assis Chateaubriand, foi lançado um curso de desenho industrial junto com outras escolas, sendo a mais frequentada a de Propaganda, hoje a Escola Superior de Propaganda e Marketing.

$N$ atural que a primeira e quase única referência fosse uma evocação, aliás uma guia, da Bauhaus de Walter Gropius, seu idealizador e realizador. (...)

$N$ ão é o caso de refazer aqui o currículo de ensino que divulgava a produção da Alemanha, utilizando a literatura que então lá se publicava. A direção da escola foi assumida pela arquiteta Lina Bo Bardi, devendo-se lembrar seu colega Jacob Ruchti, professor de valor.
Para consolidar a presença da escola foi organizada uma exposição da história das formas, registrando a evolução do objeto de uso doméstico, complementada com uma resenha da sucessão dos estilos. Começava com as formas antigas do Egito até as de nosso século, este representado por uma máquina de escrever O livetti que provocou até uma piada: teria sido esquecida ali por mim numa montagem precipitada demais. Da história do design a ignorância era total e não houve nenhuma repercussão pública apesar da afluência na escola de centenas de alunos. Trabalhava-se, contra a corrente, em campos totalmente novos. (...)

Para se ter uma ideia de como as iniciativas dos primeiros anos do MASP foram pioneiras e difíceis, basta recordar que culminaram, às vezes, até em episódios indignos de uma casa de cultura.(...)" 13

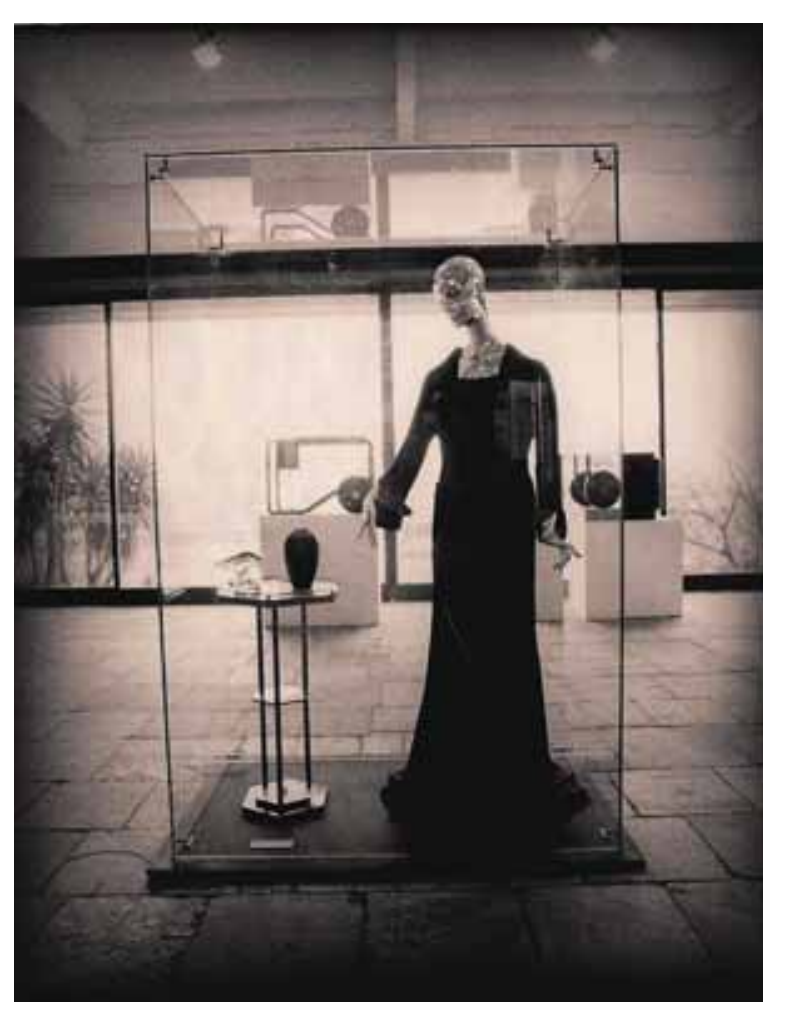




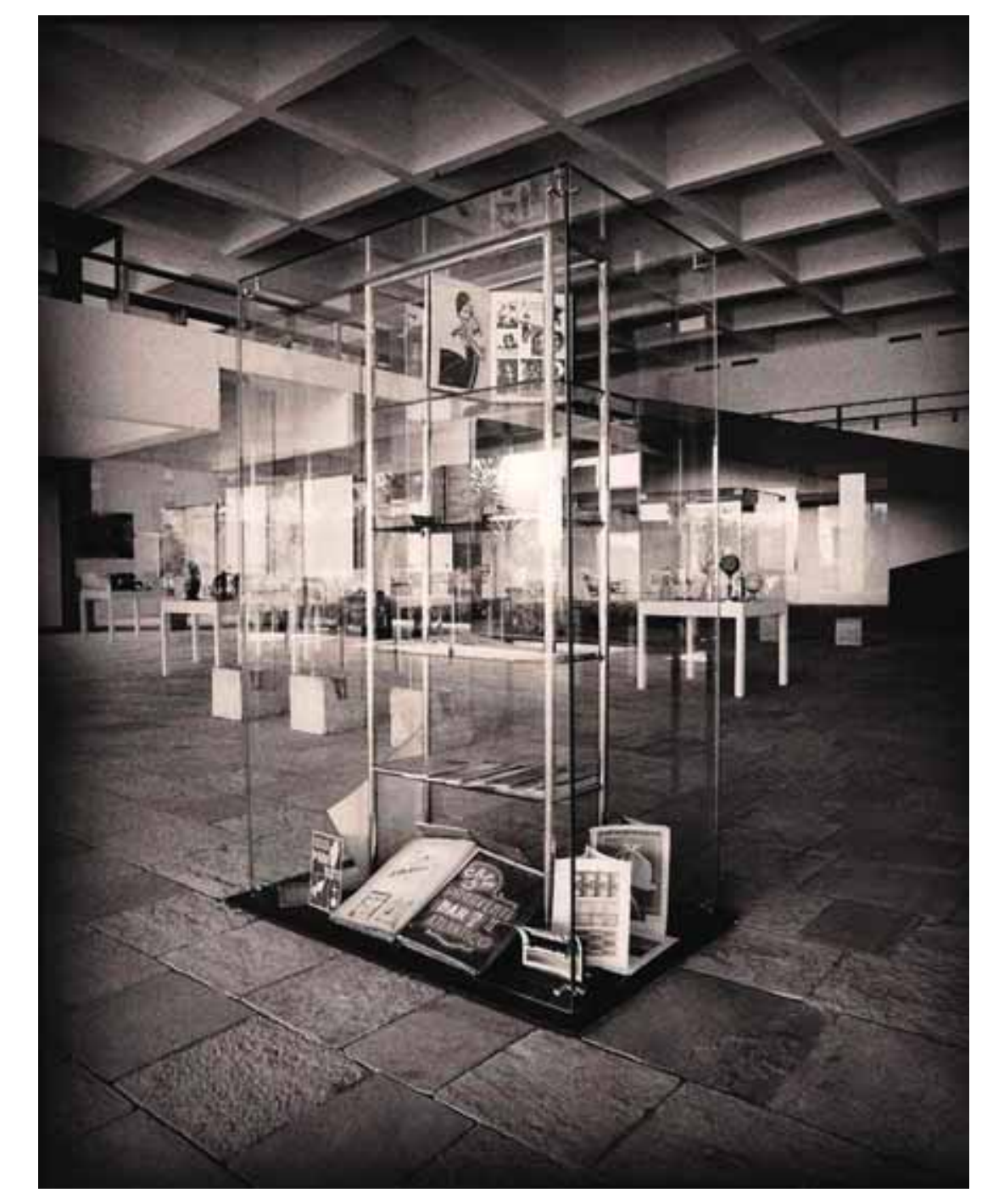

Mais uma vez, próximo ao encerramento de sua gestão como Conservador-chefe do Museu, Bardi faz um balanço da contribuição do MASP ao desenvolvimento e consolidação do design no País e, sobretudo, o reconhecimento da originalidade das iniciativas inauguradas pelo Museu, bem como da influência exercida pela experiência germânica no contexto brasileiro.

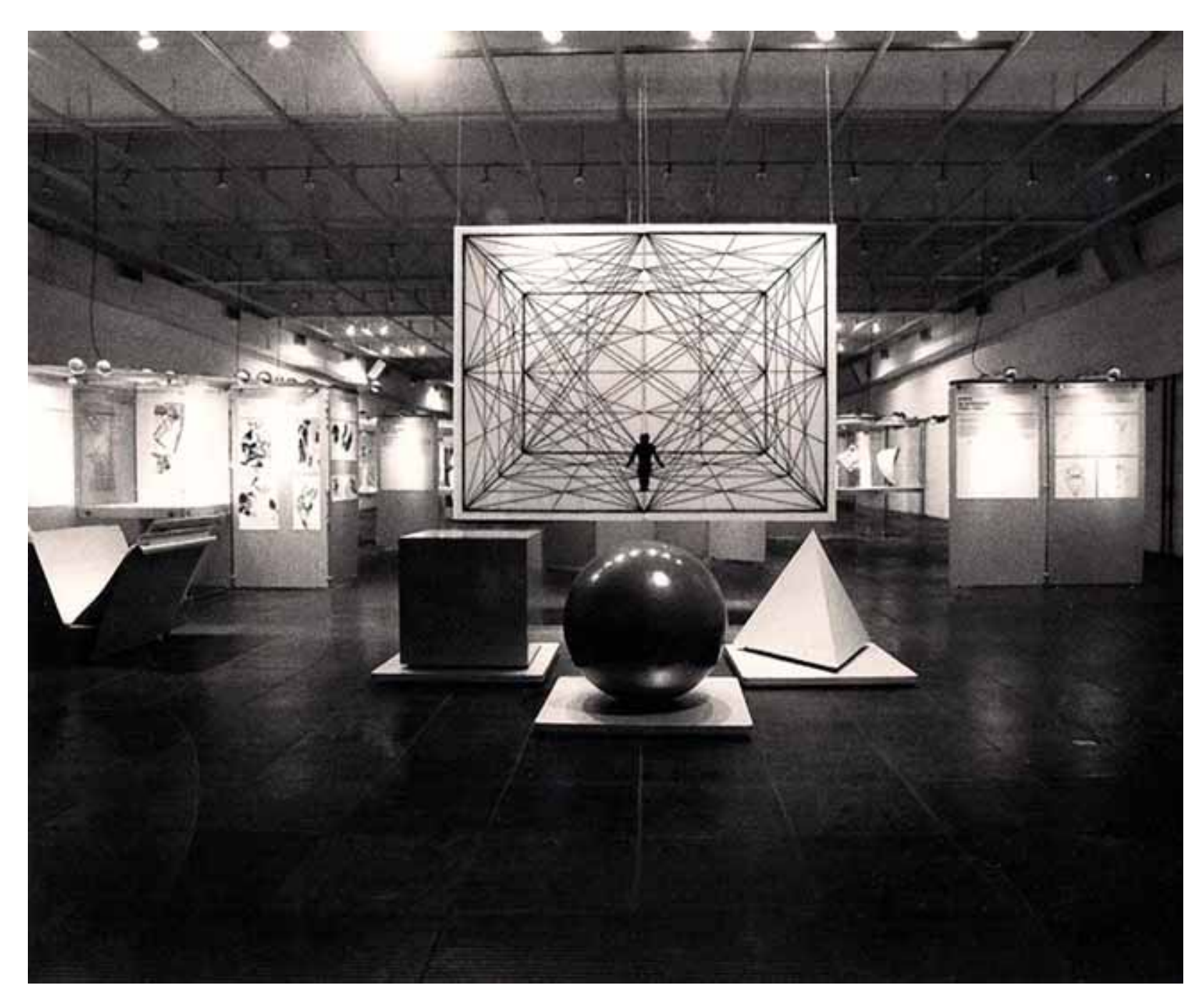


MOBILIÁRIO BRASILEIRO -

PREMISSAS E REALIDADE

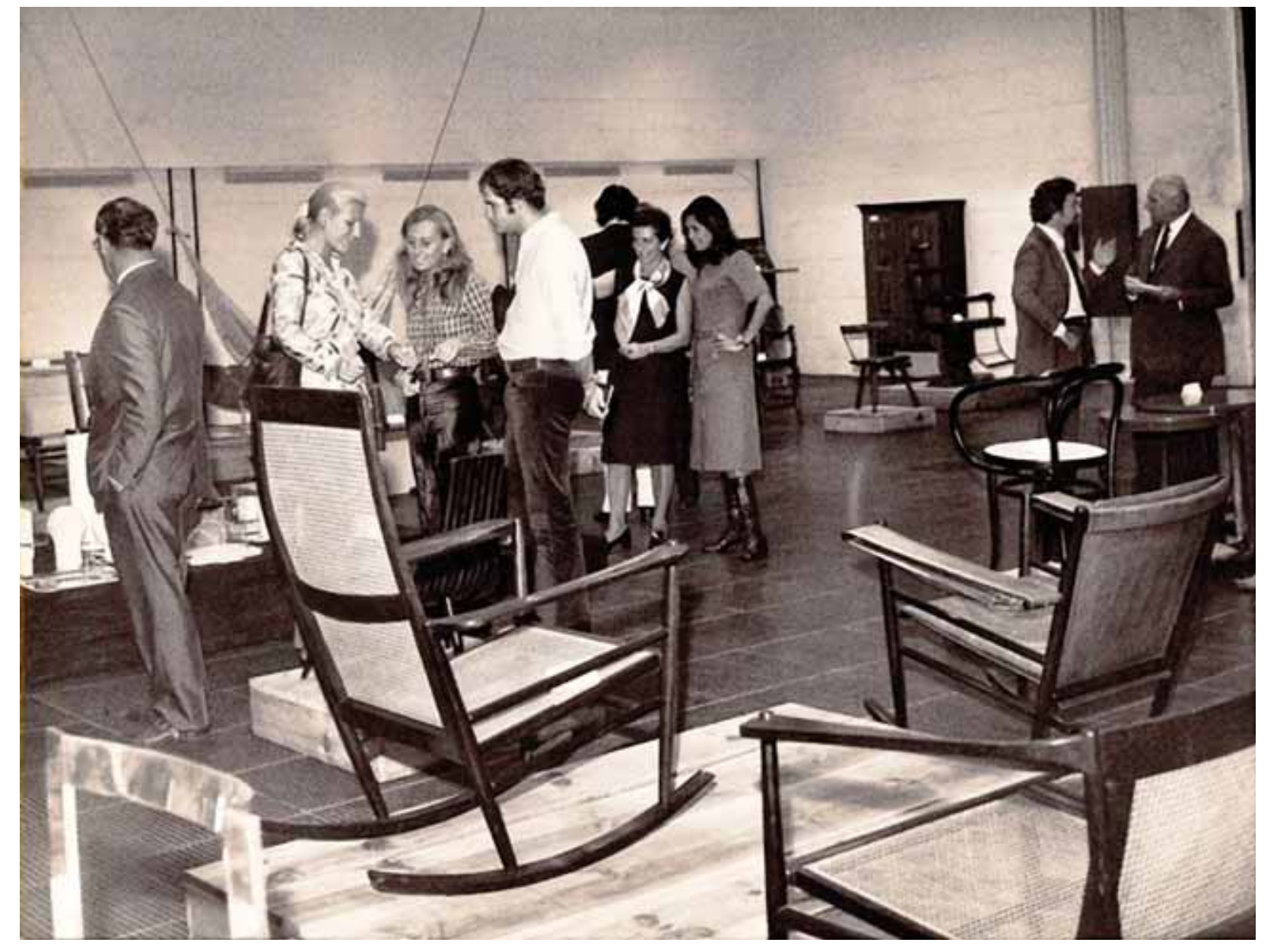

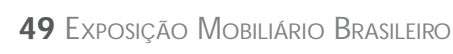

PremISAS E ReALDADE 1971

Documentacão do MASP

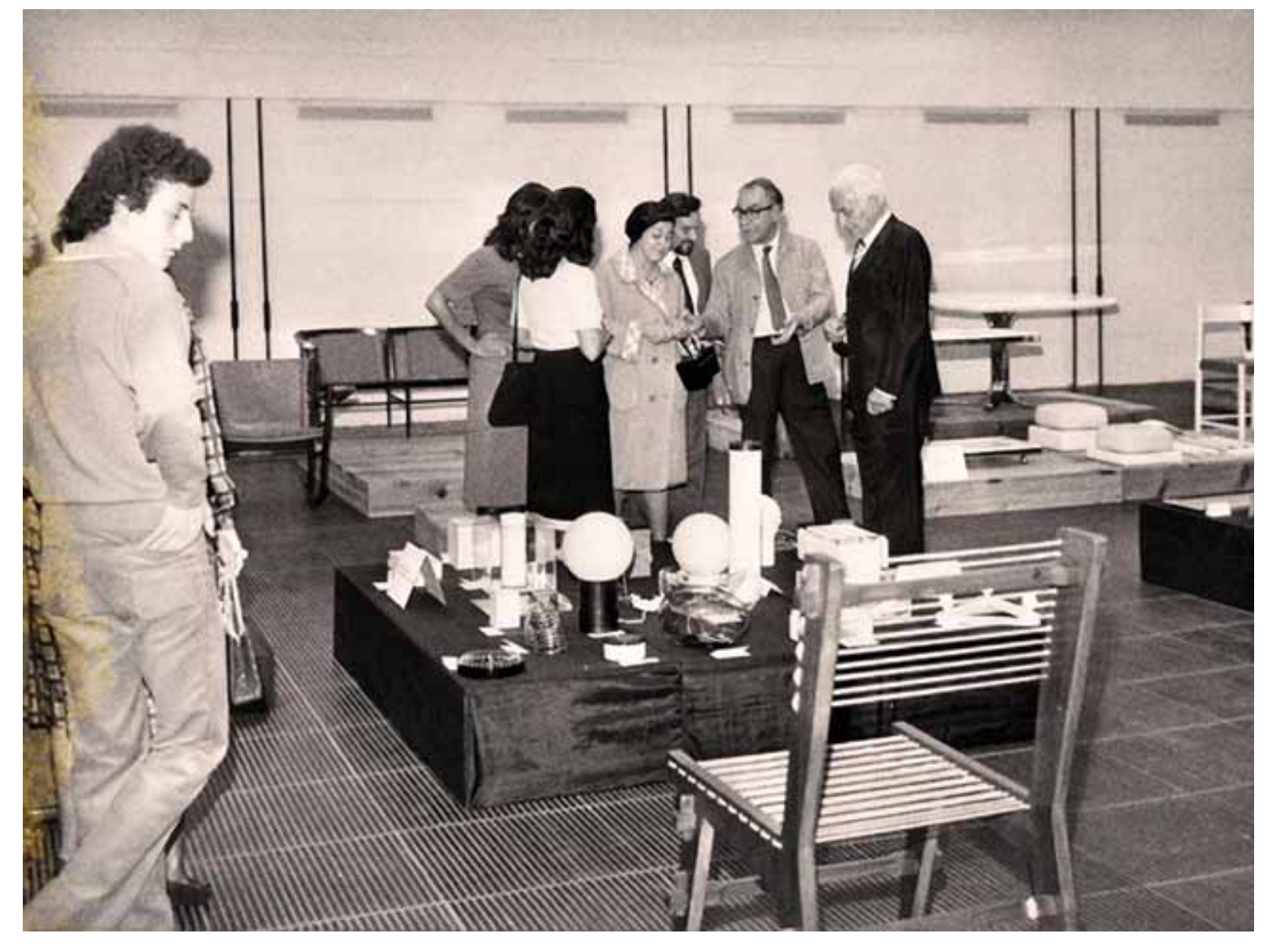

A exposição, produzida pelo Museu é uma das primeiras exposições sobre o mobiliário brasileiro, organizada dentro do espaço de um museu e guarda consigo, bem como outra exposições, a um discurso que o MASP defenderá de forma ampla até o afastamento de Lina Bo Bardi e Pietro Maria Bardi da instituição. O amplo catálogo, elaborado por ocasião da exposição, é aberto com um belíssimo e fundamental texto de Bardi, meritório de transcrição em sua íntegra, dado a sua capacidade de síntese de uma série de argumentos que perpassam todas as atividades do Museu dedicadas ao design. É também quem melhor

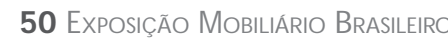
PrEmISAA E REALIDADE 1971 Documentação do MASP explica os objetivos desta exposição, mas do qual serão extraídos somente alguns trechos: 
"Pela primeira vez organiza-se, em termos museográficos, uma exposição dedicada ao mobiliário brasileiro: uma breve história e a realidade do desenho e da indústria que nestes últimos vinte e cinco anos foi se aprimorando até alcançar um nível consoante à nova arquitetura. (...)

O João V ouVI, D ona Maria, etc., são estilos, ainda que derivados de invenções inglesas filtradas em Portugal, de um caráter que se pode classificar como autóctone, pelas correções e manipulações que recebeu na operosidade colonial. Mas quando as peças são falsificadas pelo pantógrafo e envernizadas com tinta plástica, a estética sofre duros golpes. Infelizmente, há marcenarias produtoras de falsos e daquela miscigenação de pedaços autênticos enriquecidos de elementos novos - talhas de altar que se tornam mesas, pernas de mesas que viram abajurs, oratórios servindo de bares, etc. - a estética imbecil.

Felizmente as anomalias vão diminuindo, e a reprodução do móvel pseudíssimo colonial vai perdendo suas asas. Assiste-se a uma vitória, sempre mais vívida, do assim chamado moderno, do móvel conveniente, desenhado pelo homem de hoje e não pelo do século XVIII.

É curioso notar que pernósticos fãs de automóveis últimos modelos, prontos a gastar fortunas para adquirir um forade-série, preenchem seus livings com objetos antiquados e suas paredes com óleos de pobres acadêmicos. Mas é assim: a estética, para a maio ria, é uma festa organizada com do is pesos e duas medidas. Vemos em São Paulo, nos afamados jardins, as fachadas tipo Partenão, quando não modeladas à Renascença ou à Mexicana. (...)

Q uero anotar isto ligeira e cordialmente para frisar o caráter da exposição que o Museu organiza. É um convite à reflexão sobre o problema.Ao mesmo tempo é uma homenagem aos modernos séculos XVII e XVIII que deixaram belíssimas lembranças da atualidade das épocas da nossa formação, e uma anotação da vontade de atuação dos designers e dos industriais que estão procurando competir e vencer certames no estrangeiro ganhando prêmios, obtendo patentes e exportando fruto do nosso labor. (...)

Q uando em 1947 se tratou de guarnecer nosso auditório de cadeiras, não foi possível encontrar um modelo que não fosse de um estilo sem pai nem mãe. Precisou-se desenhá-lo. U ma exposição histórica paralela, no Museu, mostrou qual a evolução do assento, incluindo algumas peças contemporânea s importadas dos Estados Unidos por Rino Levi. Foram os primeiros passos para desnodar um esquema de atividades, polêmicas naturalmente, como a de lançar a advertência da necessidade de colocar-se em dia. Os arquitetos Gian Carlo Palanti e Lina Bo Bardi, titulares do Studio Palma, devem ser apontados como os primeiros propositores das formas racionais no mobiliário nacional. Eram móveis ainda ligados a esquemas culturais europeus, mas com uma procura acentuada de materiais brasileiros. Cabe observar que as produções inspiradas em modelos concebidos por uma sociedade altamente industrializada carecem de validez quando repetidas em países de outras premissas.Tornam-se exercitações estéreis. Isto explicaria a crise da Escola Superior de D esenho Industrial no Rio, baseada em proposições socioeconômicas recalcadas sobre modelos europeus como a Bauhaus de Gropius e a Escola de Ulm de Max Bill. Com isto, naturalmente, não quero dizer que precisamos nos inspirar nas produções folclóricas ou artesanais do país, principalmente porque no Brasil não existe uma verdadeira tradição artesanal, isto é, um artesanato como herança de uma determinada estrutura social. 
Existiram artesãos, muitas vezes espanhóis e portugueses e no século passado, italianos. Aquilo que se chama no Brasil de artesanato ou arte-popular é na verdade um pré-artesanato rico, às vezes, de fantasia e poesia, como no N ordeste, mas sempre um pré-artesanato.

$\mathrm{N}$ ão foi fácil, portanto, a solução dos problemas de um design nacional. Contribuíram, como disse, várias iniciativas. Merecem ser lembrados nos primeiros tempos John Graz e Regina Gomide Graz, seguidos pelos irmãos Hauner, Tenreiro,

Zanini, este último fabricante de móveis de compensado recortado e desmontáveis. (...)

Arquitetos do valor de S. Rodrigues, Cauduro, Begmiller Pontual, Arnoult e Westwater devem ser apontados como bons contribuintes no desenho do mobiliário atual. Particular animação foi dada à difusão do móvel contemporâneo por Leo Seincman.

É verdade que 0 estilo 'E o vento levou' ainda não carregou seus comparsas para o reinado do ridículo, por outro lado, quem é prático de história do gosto sabe perfeitamente que existem períodos de transição; mas também é verdade que nasceu e prosperou uma arquitetura ajeitada à contemporaneidade e participante da efervescência do nosso tempo, demasiadamente International Style, mas em todo o caso um antídoto do Culturalismo. (...)

De qualquer jeito, na exposição que o Museu está inaugurando, essa estética foi banida. Apresentamos exemplos que nos parecem dignos e coerentes com os tempos. $\mathrm{Nem}$ todos os designers e as indústrias estão presentes neste primeiro encontro que esperamos repetir em maior escala nos próximos anos e, estamos certos que, em breve, o perío do de transição do qual falamos, se acabará." 14

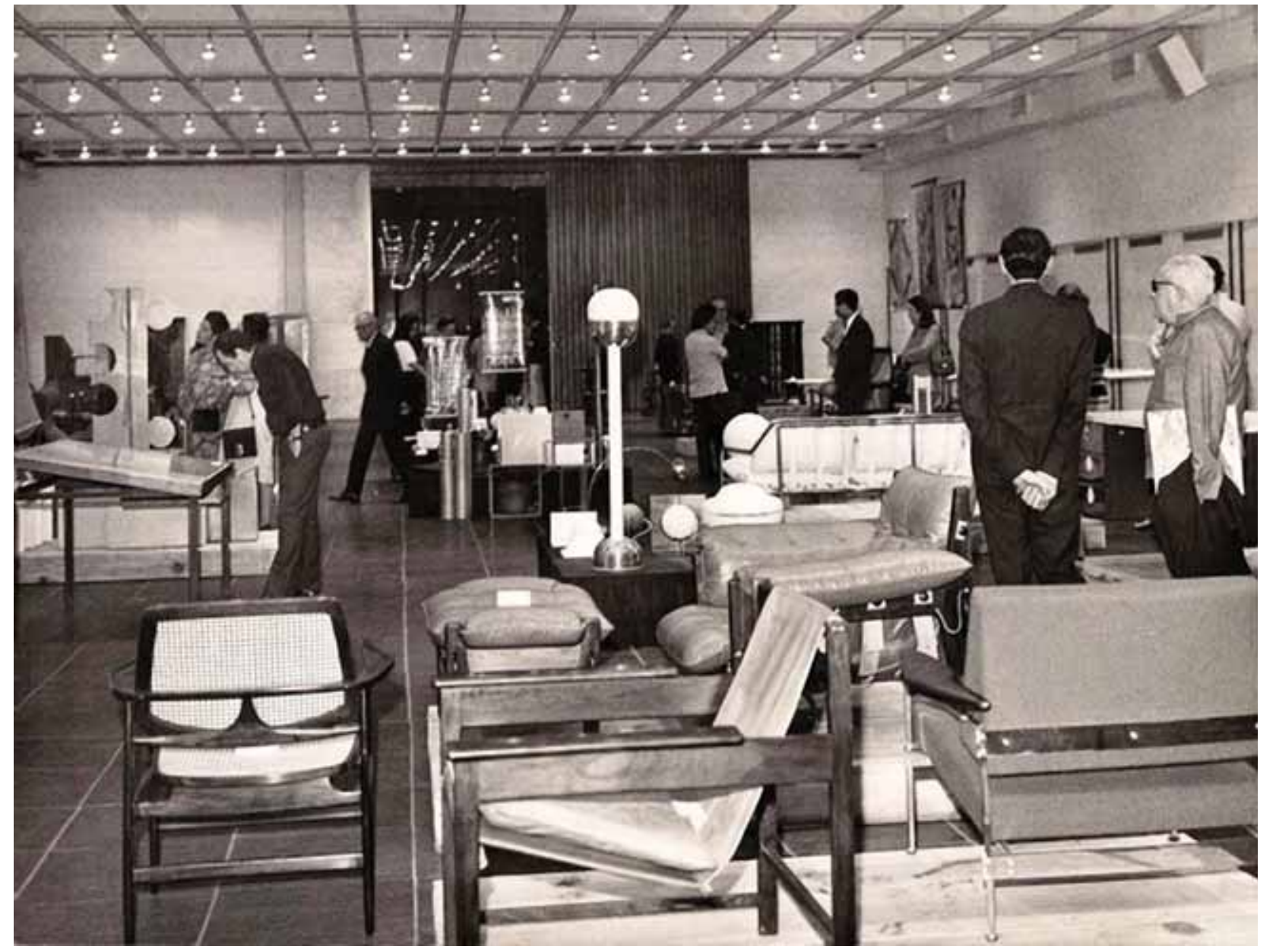

E é por meio deste texto que se retoma a convicção que orientará de forma singular o discurso do Museu acerca do design. Ao retomar exemplares originais dos séculos XVII e XVIII, valoriza-os na medida em que os compreende como respostas mais adequadas $\mathrm{d}$ produção às técnicas, materiais e conteúdos próprios de sua época. uma concepção do design e, também, da arte, como consequência do meio - em consonância com os processos técnicos, históricos e estéticos pertinentes de uma determinada sociedade dentro de uma

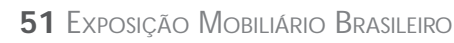
PremISAS E ReaLDADE 197 blioteca e Centro de E a partir dessa perspectiva, vê na produção contemporânea citada resposta mais adequada às demandas da sociedade brasileira. 


\section{N OTAS}

1. As relações entre o desenvolvimento do design e as orientações político-econômicas brasileiras são retomadas brevemente aqui, porém o tema é extensamente debatido nos textos da autora A nos 1960: a situação brasileira e suas relações com o contexto internacional e Anos 1970: o panorama histórico de um milagre que não se sustentou. In: CARA, Milene. Do Desenho Industria ao design no Brasil: uma bibliografia critica para a disciplina São Paulo: Blucher, 2010.

2. "(...) a ação do Estado ressentiu-se de uma melhor ar ticulação com a política agrícola que promovesse sobretudo o crescimento da produção de alimentos básicos, de modo a viabilizar o crescimento econômico com ganhos de salário real eincorporação ao mercado de contingentes populacionais marginalizados; de melhor articulação setorial, de modo a evitar o atraso relativo de alguns setores, a heterogeneidade tecnológica e as substanciais diferenças nos níveis de produtividade; do desenvolvimento de um sistema financeiro privado capaz de mobilizar recursos para créditos de longo prazo para investimento, até hoje dependente das agências públicas de fomento, e de melhor articulação socia que promovesse melhor distribuição de renda e maior acesso das camadas de mais baixa renda ao mercado e aos serviços sociais básicos como educação, saúde e habitação." VERSIANI, Flávi R. e SUZIGAN, Wilson. 0 processo brasileiro de industrialização: uma visão geral. p.25-26.

3. VERSIANI, Flávio R. e SUZIGAN, Wilson. 0 processo brasileiro de industrialização: uma visão geral. p.25-26. (Texto preparado para a seção relativa à industrialização da América Latina no X Congresso Internacional de História Econômica, Louvain, agosto de 1990)
4. Idem. p.268.

5. VERSIANI, Flávio R. e SUZIGAN, Wilson. 0 processo brasileiro de industrialização: uma visão geral. p. 21.

6. FAUSTO, Boris. História Concisa do Brasil. São Paulo: Editora da Universidade de São Paulo: 2006. p. 279

Discurso proferido por Aloísio Magalhães durante os simpósios da 29 reunião anual da Sociedade Brasileira para o Progresso da Ciência (SBPC) realizado em São Paulo. In: LONDON, Valéria Munk. A contradição entre criatividade e a importação de tecnologia - o dilema do desenho industrial brasileiro. Jornal do Brasil, 25 de julho de 1977.

3. Carta de Carmem Portinho redigida à Pietro Maria Bardi em 21 de dezembro de 1970, transcrita de documento original do arquivo histórico do MASP

9. BARDI, Pietro Maria. In: Exposição de Desenho Industrial da Escandinávia. Museu de Arte de São Paulo, 04 a 21 de março de 1971. Catálogo da exposição.

10. Da exposição Produto - Forma - HistóRIA - 150 ANOS DE Design Alemão não foram ainda localizadas imagens pelo Centro de Documentação do Museu. Estas pertencem a exposição BAUHAUs, realizada em 1974, aqui apresentadas em virtude da proximidade dos discursos.

11. ROLIM, J. Henrique Fabre. D esign alemão - Um marco nas artes. A Tribuna. Santos, 26 de novembro de 1988

12. Nota publicada no Jornal Folha de São Paulo, 14 de novembro de 1988.

3. BARDI, Pietro Maria. A influência de Bauhaus. Isto é Senhor, $30 \mathrm{de}$ novembro de 1988

14. BARDI, Pietro Maria. O Mobiliário Brasileiro. In: Catálogo exposição Mobiliário Brasileiro - Premissas e Realidade. Novembro/ Dezembro de 1971. Museu de Arte de São Paulo Assis Chateaubriand. 
As proposições no campo gráfico refletem, com maior velocidade, o ambiente cultural dos anos 1960 e 1970 um dos períodos mais significativos e afortunados nos mais diversos campos do conhecimento. "As rupturas foram de toda a ordem: po líticas, so ciais,artísticas, científicas e co mportamentais." O idealismo por uma sociedade mais justa e sem conflitos de classes ou raças alimentou o desejo de revolução em joven de todo o mundo; favorecendo a construção de novos horizontes, não somente políticos e comportamentais, mas também culturais. Basta recordar a ampla difusão de imagens dos ícones revolucionários, como Che Guevara; o registro das manifestações estudantis em Paris, no ano de 1968; a Guerra do Vietnã ou o movimento black power no Estados Unidos - todos estímulo ao desejo de superação dos conflitos de toda a ordem, colocando em cheque autoritarismos de qualquer natureza.

E no campo da arte, no contexto internacional, os reflexos dessa vontade são expressos no início da reconsideração das conquistas do movimento moderno e, primeiramente na arquitetura.

"Impõe-se a crítica à teoria modernista por meio da coexistência de tendências contraditórias, cujo objetivo final é o desejo de superação dos limites impostos, sobretudo, pelos rígidos princípios hegemônicos do movimento moderno até então em voga: o formalismo e o funcionalismo, consagrados pela expressão "a forma segue a função", a necessidade de ruptura radical com a história e a expressão "honesta" da estrutura e do material." 2

Este é, então, o início do período designado pela expressão "pós-moderno", contendo em si extensos debates controvérsias, porém, guardando, ao menos, um único consenso: um momento marcado pelo pluralismo de questões como um contraponto às convicções pretensamente universais e totalitárias que definiram o modernismo.
Uma possível explicação para a proximidade do debate dedicado ao campo gráfico às reflexões que tinham como tema a crise do moderno ao contrário do objeto, talvez seja, o forte vínculo do discurso dos objetos à arquitetura moderna, esta última que atingira no Brasil, sobretudo, nos anos 1950 e 1960, um elevado grau de excelência com amplo reconhecimento internacional Basta verificar que a reconsideração do legado modernista e suas premissas é ainda hoje, no País, uma discussão bastante frágil, sobretudo no ambiente das escolas de arquitetura. As primeiras exposições dedicadas a discutir o objeto no País estão relacionadas muito mais à problemática do móvel moderno com vistas a atender a demanda arquitetônica em crescimento do que à problemática do produto industrializado produzido em larga escala. Basta relembrar que uma exposição dedicada a reunir produtos industriais produzidos no País se dá somente no final dos anos 1980, exposição esta citada no ensaio anterior.

A inércia do setor industrial brasileiro em relação à pesquisa e o desenvolvimento de novas tecnologias com maior capacidade de produção, sobretudo do ponto de vista qualitativo, é também um dos aspectos que podem revelar a dissonância do debate do produto em relação às discussões em voga no ambiente internacional. Basta recordar que até finais da década de 1990 a produção de designers como Fernando e Humberto Campana é altamente marginalizada, sobretudo nos ambientes acadêmicos dedicados à pesquisa do produto, na medida em que é atribuída ao campo da arte. No entanto, tal produção é acolhida no ambiente internacional que, dada a sua capacidade tecnológica, consegue apreender do objeto criado pelos designers, as condicionantes para sua produção em escala industrial. Seria arte? Se consideradas as reflexões de Bardi, sem dúvida. Design também é arte. Porém, tal consideração, à época, pretendia relegar a obra dos designers ideia do objeto único num sentido marginal ao campo do design. Não seria a nossa capacidade produtiva nacional demasiado obsoleta para compreender novas linguagens estéticas, que não as mais afeitas às estruturas produtivas do período? 
No entanto, este ensaio, dedica-se à reflexão, ou melhor, a contribuição ao discurso do design gráfico por meio das exposições e é possível elencar, ao longo da história do Museu, inúmeras delas dedicadas ao tema: a primeira delas, já citada anteriormente, ocorre no I Salão Nacional da Propaganda, ainda em 1951, na qual, ao lado da produção contemporânea de propaganda nacional e internacional, figurava também, uma representação dos artistas - dedicada à exibição de cartazes de Toulose Lautrec e litografias de Cheret, cedidas pela Galeria Knoedler, de Nova York - cujo objetivo era defender a compreensão da propaganda como arte. Já em 1953, a exposição de cartazes do catalão Eduardo Badia Vilató tinha como objetivo também reforçar a visão da publicidade enquanto expressão artística.

Em 1966, a exposição Coletiva Olivetti inaugura uma ampla importante relação da empresa com o Museu, à medida em que ambas compartilham de uma mesma visão acerca das relações entre arte e indústria. A pedido da Olivetti, o MASP abriga uma exposição dedicada a apresentar obras de artistas brasileiros inspiradas nas visitas realizadas à fábrica da empresa em Guarulhos, São Paulo. A iniciativa também teve como proposta a organização de um debate sobre o tema das artes plásticas na civilização tecnológica moderna - Civilità delle macchine, cujo objetivo foi suscitar um análise aprofundada das relações entre arte e tecnologia, de grande atualidade ao País que, àquela época, ingressava num crescente processo de industrialização.

Em 1972, novamente com o patrocínio da Olivetti, seria trazida ao Brasil e para o Museu, conforme já citado, a importante exposição PUsh Pin StUdio, escritório norte-americano de Milton Glaser e Seymour Chwast, um dos mais influentes à época A autêntica produção do Push Pin apresentava o uso de uma grande ariedade de estilos e técnicas. Uma linguagem consoante com o pluralismo da sociedade contemporânea, pós-moderna, na qual a sua produção representava uma síntese das quebras de paradigmas do período: uma ruptura às escolas onde predominavam rígidas regras para a concepção - tais como a Bauhaus e a Escola de Ulm.
Mais uma vez, em 1976, a Olivetti está presente no Museu, retomando as discussões dedicadas ao tema das relações entre arte e indústria, por meio da exposição Os Artistas e a OlivetTI na qual expõe seu importante acervo encomendado pela empresa ao longo dos anos, seja para reproduções nas agendas da companhia; reproduções em livros editados por ocasiões de assembleias, seminários e convênios e para suprir as necessidades internas de decoração dos escritórios da empresa.

Para compreender a relação e a admiração de Bardi à Olivetti, é necessário compreender o significado desta empresa para o contexto da produção industrial no período. A Olivetti, à época, uma experiência que nasce da visão de uma família, os Olivetti, que representam um papel ímpar na história da industrialização ocidental. Ainda em 1893, Camillo Olivetti, engenheiro culto erudito, pai de Adriano, viaja aos Estados Unidos da América (EUA) para a Exposição Universal de Chicago. Uma experiência fundamental, na qual estuda a produção de máquinas norteamericanas com o objetivo de superá-las, mas também verifica as relações espaciais entre fábricas e a ocupação do espaço pelos trabalhadores (moradias). A atenção ao lugar onde se constrói uma fábrica e a atenção às vidas dos operários que vão morar ao redor desta empresa são duas preocupações constantes da Olivetti.

Ao retornar à Itália, elege a cidade de Ivrea para a fundação a sua fábrica. A primeira máquina de escrever italiana - a $\mathrm{M}$ (Machina 1) - já é comparável aos modelos norte americanos. Um dos aspectos mais favoráveis é o menor número de peças para sua construção em relação a uma Hamilton, considerada uma das melhores máquinas do mundo à época. Camillo não se limita às considerações tecnológicas do produto, mas também às sociais. É ele quem vai instruir e ensinar os operários a produzir Trata-se na Itália, bem como no Brasil àquele momento, da passagem do universo rural para um universo agrícola. Em 1915 cria uma sociedade de beneficência mútua com os percentuais dos lucros divididos em $75 \%$ para a Olivetti e 25\% para os empregados e, no mesmo ano, inicia as campanhas publicitárias. 
Em 1924, a M40 já é a melhor máquina de escrever do mundo, ano também no qual Camillo se aposenta, momento em que Adriano Olivetti, que nascera em 1901 e formara-se em engenharia química, se prepara para assumir o negócio da família. No início, vai trabalhar na firma do pai como operário durante um ano na linha de produção, e depois vai aos EUA, interessado em saber sobre as formas de organização do trabalho e de técnicas que tornavam a produção industrial cada vez mais eficiente. $O$ fato determinante é que a Olivetti não comprava os componentes para fabricar suas peças, mas estudava e produzia seus sistema próprios de construção. Isso também geraria uma renda significativa à empresa.

Adriano assume a empresa em 1927 e no mesmo ano abre um centro de comunicação publicitária em Milão. Em Ivrea abriria em 1928, um centro de estudos tecnológicos para a inovação da produção. Identifica a necessidade de uma identidade moderna e convoca o Studio Boggeri - estúdio que não se limita apenas a fazer propaganda, mas cria uma série de elementos nos quais a imagem do produto é parte da comunicação.

A empresa cria seu centro de propaganda como osmose e intercâmbio entre uma necessidade interna da empresa as condições ou exigências sociais daquele momento. Adriano tem como visão o papel da empresa como produtora de progresso, sobretudo, progresso humano, numa tentativa de transformação da sociedade. Cria escolas para operários, aulas de sindicalismo instrumentos para a construção de uma identidade e ainda pagava $20 \%$ a mais para os seus operários, não como filantropia, ma como resultado da organização da produção, que permitia um lucro maior, que ele considerava justo dividir com os operários, inclusive por meio de financiamentos a juros zero para a construção de casas e etc.

O lançamento da máquina portátil, como instrumento de trabalho, abriria um novo mercado de trabalho também em casa. Com a M42 surgem mudanças nos paradigmas da produção.
Entram no centro de propaganda alguns intelectuais bastante importantes: poetas, críticos de arte: Sinisgalli, Vittorini e Franco Fortini - intelectuais importantes e jovens - numa compreensão dos intelectuais como os melhores interlocutores dos valore promovidos pela empresa.

A empresa antecipa uma visão da Modernidade enquanto mundo da imagem. Estruturas para os trabalhadores são executadas por grandes arquitetos italianos - valor ou ética da beleza - sem perder de vista a preocupação com a comunidade, na qual Adriano anteciparia a noção contemporânea de responsabilidade social.

Em 1952, a Olivetti é a empresa líder no mundo em seu segmento. No mesmo ano realizaria a exposição Olivetti: Design NA IndÚstria, no Museu de Arte Moderna de Nova York (MOMA - NY). É o reconhecimento de uma cultura industrial italiana, porém uma cultura predominantemente rural no pós II Guerr Mundial. A empresa não se limita somente a campanhas na qual pretende criar uma identidade colada ao produto, mas tem como objetivo a transmissão de uma cultura industrial, moderna, preocupada com a sociedade. A presença no Brasil e particularmente no MASP, por meio das inúmeras exposições, se dá nesta perspectiva, na valorização das relações entre arte, indústria e sociedade, aspectos também amplamente defendidos por Bardi desde a fundação do Museu.

É a Olivetti que melhor entenderá, antes mesmo da IBM, o papel da imagem para a construção da identidade corporativa, nicho de atuação que abrigará a maioria dos designers brasileiros da segunda metade do século XX, como será possível constatar nas exposições dedicadas ao design gráfico brasileiro. Porém, a estratégia italiana não se limitava à construção de imagem restrita às necessidades de desenvolvimento tecnológico e crescimento econômico, o desenvolvimento humano era tema de igual grandeza na visão dos Olivetti.

Àquele momento, a empresa expandira-se pelo mundo e particularmente, na América Latina: com a fábrica na Argentina, 
projetada por Marco Zanuso, e no Brasil. A sede da empresa localizava-se em um edifício projetado por Palanti e a fábrica em Guarulhos, novamente, por Marco Zanuso. Adriano Olivetti morreria em 1960 e nas décadas seguintes, na revolução eletrônica, a empresa perderia sua posição de liderança à IBM. ${ }^{3}$

Vale ainda ressaltar que, as relações do Museu à visão italian para o campo do design não se limitam somente às exposições patrocinadas pela Olivetti. No ano seguinte, 1977, o MASP abriria seu espaço a duas exposições: Firma ITÁlia - ARTE, CINEMA, GRÁFICA, PUBLICAÇÕES, TELEVISÃO NA COMUNICAÇ̃̃O INDUSTRIAL italiana e Gráfica Italiana Contemporânea. Na primeira, traz a produção recente italiana dedicada à construção da imagem das indústrias italianas por meio da comunicação, dirigindo-se aos que atuavam nos campos da comunicação, do design e ao público, mas prioritariamente, aos industriais, à classe produtor brasileira. Esta exposição seguiu do MASP, para o MAM- R. A segunda trouxe 150 reproduções assinadas por designersitalianos.

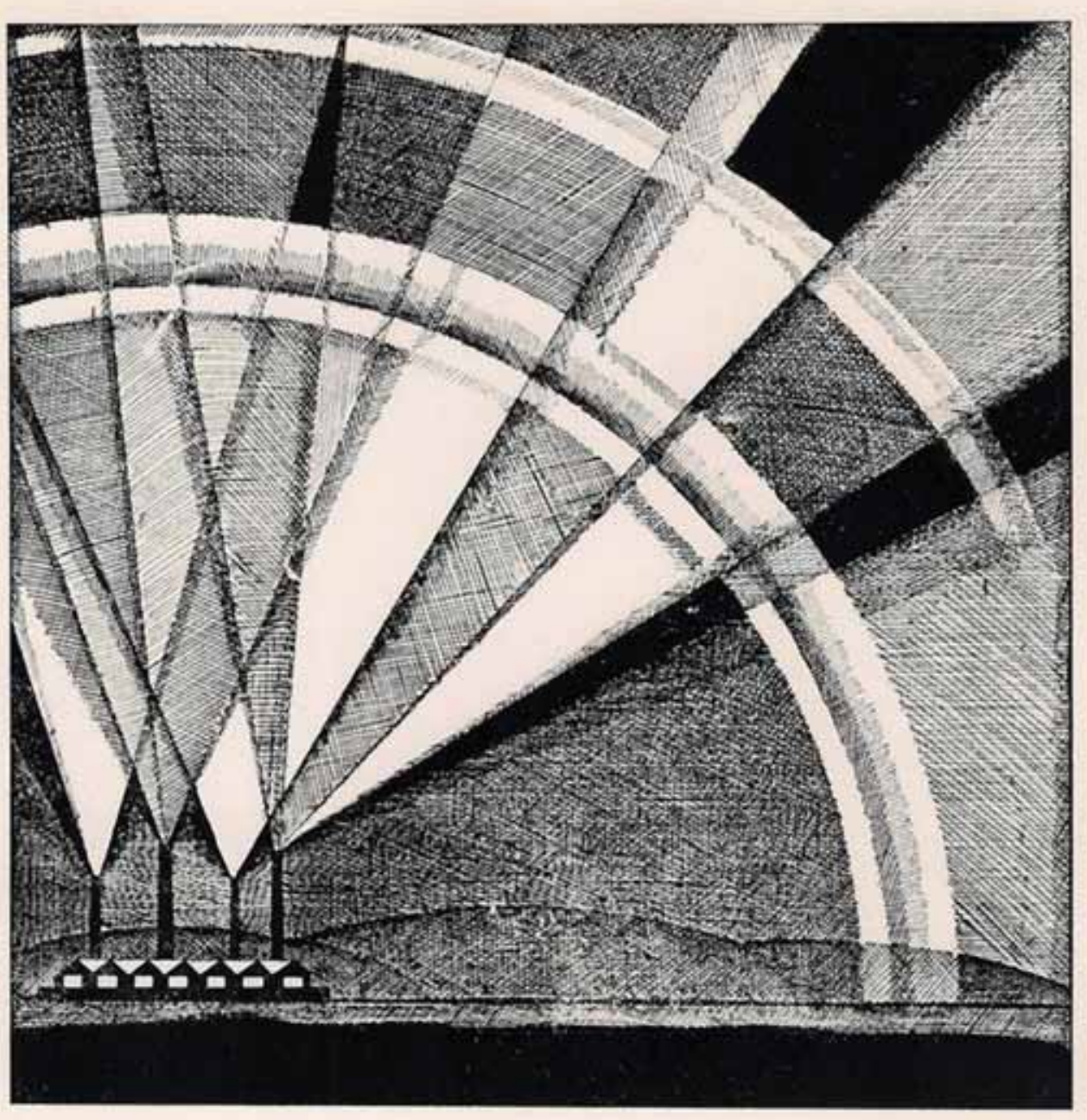

SOCIETA' ANONIMA PER LINDUSTRIA DELLA TINTORIA

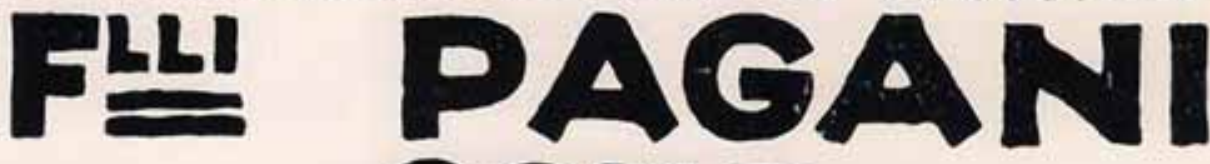
COMO

TUTTI GLI ARTICOLI IN FILO

E PEZZA,PURI E CARICATI 


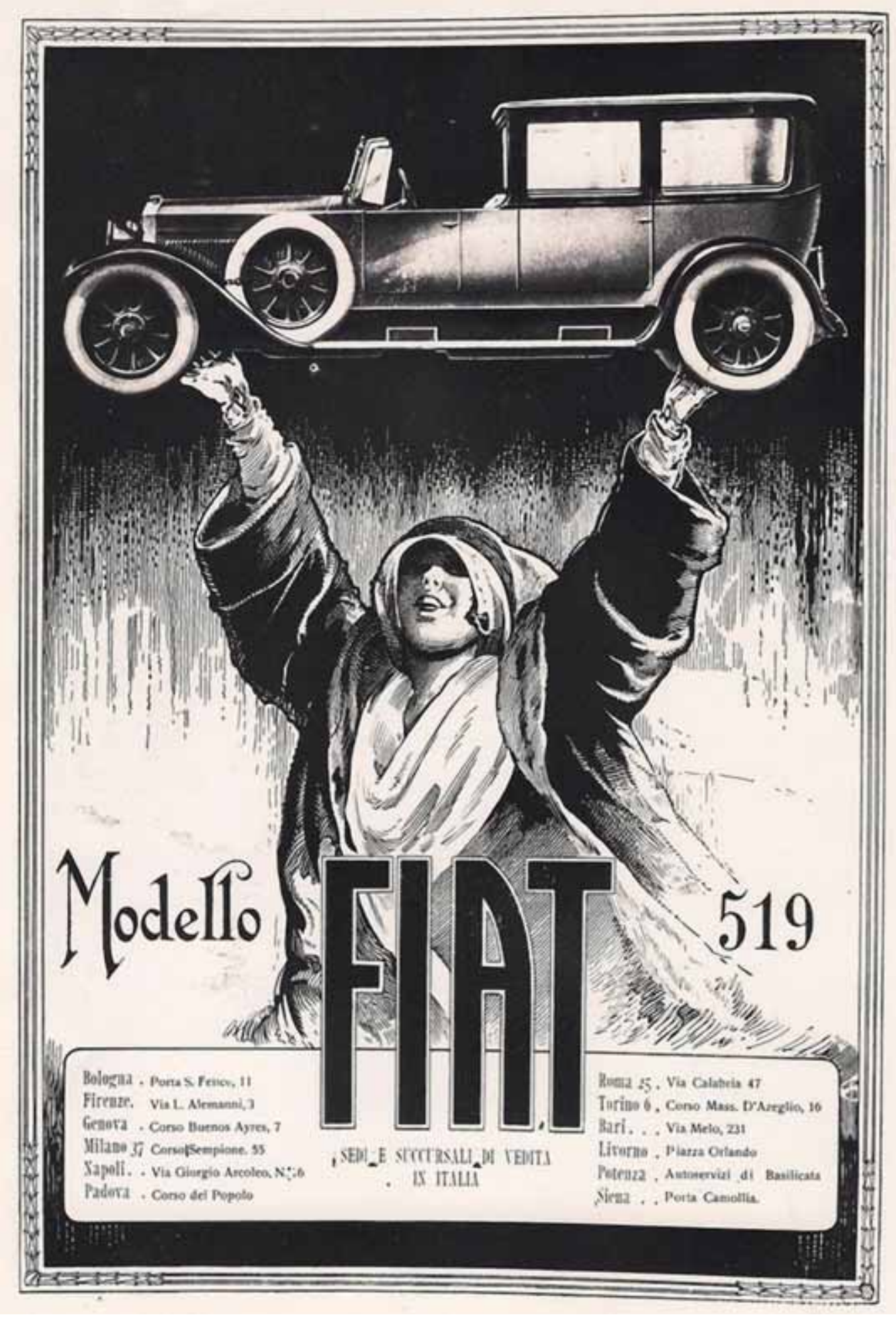
a partir da seleção de 104 pôsters selecionados dentro da coleção de Alan Mabey (1904 - 1976), compondo uma espécie de história abreviada da evolução do design gráfico inglês, da virada do século à II Guerra Mundial. Em 1982, ocorre A ARTE Do CARTAZ CONTEMPORÂNEO NO JAPÃO, cujo objetivo, assim como o da mostra dedicada ao cartaz britânico, é o de retomar a abordagem histórica na qual se entende a produção como resposta à totalidade dos aspectos culturais, técnicos e históricos de um país.

Em 1983, seria a vez da exibição dos CARTAZES HISTÓRICOS DA COMUNIDADE EUROPEIA e, no mesmo ano, ocorreria, patrocinada pela Fiat, a exposição ITÁLIA, UM PAÍ́ MODELADO PELO HOMEM.

A exposição surgira a partir de pesquisa encomendada pela Fundação Agnelli à Univesidade de Yale, por meio da qual se pretendia conhecer a visão norte-americana sobre a Itália. A Fundação decidiu empreender um amplo programa de promoção para a construção de uma nova imagem do país no contexto internacional. Diferentemente de antes, um país associado à máfia, massas e Michelangelo, a mostra pretendia apresentar uma Itália que, àquela época, ocupava a sétima posição como potência industrial, resultado da criatividade de milhares de pequenos artesãos e pequenas indústrias que uniam arte e tecnologia.

Nesta mesma abordagem, ainda é possível reunir as exposições: Obras do Type Directors Club de Nova York, realizada em 1985; Exposição de Cartazes Obras-Primas do Cinema Francês, no ano seguinte; novamente Pôsters BritÂNICOs 1890 - 1980 em 1987; EPOPEIA EDITORIAL - UMA HISTÓRIA DE INFORMAÇÃO E Cultura, também em 1987; a Primeira Mostra Internacional de Pôsters Ecológicos, em 1988 e a Exposição de CAPAs da Revista Italiana De Arte FMR, também no mesmo ano.

São, portanto, inúmeras as exposições dedicadas a apresentar a produção gráfica contemporânea internacional propostas pelo Museu. Os objetivos são vários: desde ampliar a compreensão acerca do campo gráfico - design como arte - a partir de uma perspectiva 
também ampliada do campo da arte; apresentar a pluralidade de linguagens presentes do campo gráfico internacional, sobretudo com forte presença das produções italianas e saxã e, por fim, a relevante recorrência da experiência da Olivetti, como experiência fundamental para o debate das relações entre arte e indústria à época.

Já as exposições dedicadas à produção gráfica brasileira surgem no Museu, à exceção dos salões de propaganda, em meados da década de 1970. A maioria delas dedicadas à produção de expoentes do design gráfico brasileiro, sobretudo corporativo, dedicado à criação das identidades empresariais fundamentadas no repertório formal modernista. Faz-se uma exceção: a exposição HistórIa DA Tipografia no Brasil dedicada a um mapeamento da Tipografia no Brasil desde a implantação da Imprensa Régia, no início do século XIX.

A primeira delas ocorre em 1974, cujo título Emilie Chamie - TRABAlHOS GRÁFICOS, FOtOGRÁFICOS E PROGRAMAÇão VISUAL, evoca a uma retrospectiva dos melhores trabalhos gráficos realizados por Emilie Chamie, entre os anos de 1954 a 1974 Emilie frequentara os cursos do IAC - MASP nos anos 1950 seus trabalhos, com forte presença da linguagem modernista, também se destacaram, sobretudo, pela prevalência da expressão artística aos aspectos puramente técnicos. E é justamente para esta característica que Pietro Maria Bardi chamaria a atenção em seu texto no catálogo da exposição:

“(...) Não é afiliada do purismo suíço que nos Trópicos é desambientado, procura uma comunicação corretamente atual porém saborosa de inventiva enraizada no espírito da terra gosta de representar sem recorrer a modos de efeito: suas poéticas fotografias, um cartaz, uma paginação, uma marca para aindústriasão produções serenas,não gritantes,correspondendo ao caráter reflexivo e calmo da autora.
Gráfica limpa, jamais rabiscada e virtuosística, numa declinação atenta de valores conjugados à facilidade de entender rápido e fácil. Ideação e produção são intimamente interligadas, tendo presente um design como expressão de arte, não de prática técnica. $\mathrm{Na}$ nascente história do design no Brasil, ainda pioneiríssima, pela situação em que transitam os problemas sociais e culturais, Emilie tem sua posição de notável contribuinte, convencida que o design, tal como andou sendo generalizado e mecanizado, está à beira de uma crise. Parece necessitar da intervenção de pingos de fantasia e - sem pensar no radicalismo ruskiniano e morrisniano atingir mais a simplicidade artesanal e 0 espírito popular." ${ }^{4}$

No ANO SEgUiNTE, 1975, SERIA A VEZ DA EXPOSIÇão Cédulas do Brasil, da qual são poucas as informações localizadas no Centro de Documentação do MASP. Sabe-se que se tratava de divulgar o papel moeda brasileiro. A mostra, de sentido didático, tinh como objetivo permitir ao visitante tomar um conhecimento dos tipos de cédulas que circularam em nosso País, seus fabricantes e como se desenvolvia o processo de fabricação do dinheiro de papel.

Em 1977, a exposição Panorama da Identidade Nacional Empresarial, com o apoio de Marco Antonio Amaral Rezende, então presidente da Associação Brasileira de Desenho Industrial (ABDI), teve como proposta, por meio da exibição de inúmero programas de identidades visuais de empresas brasileiras expostos em painéis, analisar as diversas questões e conceitos referentes à elaboração e implantação de programas de identidade visual, uma das principais áreas de atuação dos designers brasileiros. Infelizmente, são poucas as fontes a respeito da exposição ocalizadas no Centro de Documentação do MASP. Em 1979, ocorreria a exposição História DA Tipografia no BrasiL, de caráter histórico, que novamente retoma a compreensão do design como manifestação do contexto no qual esta se dá - a partir 
da reunião de um vastíssimo material: capas de livros, famílias tipográficas, reproduções de vinhetas, anúncios e livros; pretendese evidenciar o desenvolvimento dos processos de impressão no País e refletir sobre as relações entre a expressão escrita, a gráfica e a política no contexto brasileiro. ${ }^{5}$

Na década de 1980, são organizadas retrospectivas sobre a obra de importantes designers para a consolidação do campo no País. No ano de 1980, Alexandre Wollner tem sua primeir exposição dedicada a sua obra, ao completar 20 anos de carreira, o designer não opta por uma retrospectiva, mas por uma tentativa de mostrar o processo de criação, execução e implantação de um programa de identidade visual, numa postura didática. A exposição ocupou o primeiro andar do Museu, com 40 painéis organizados de forma a estabelecer duas diagonais: uma dedicada ao processo criativo e outra ao processo de implantação de uma identidade visual. Artigos publicados à época reforçam a discussão acerca da pesquisa de uma identidade apoiada em elementos nacionais para o campo:

“(...) Formado na Hochschule Fuer Gestaltung, de UIm, na A lemanha 0 cidental, A lexandre Wollner é um dos dois ou três nomes que, ainda hoje, marcam o design gráfico brasileiro. Design brasileiro? A denominação é questionável, mas afirma Wollner, "é preciso que partamos para isso, a exemplo do México, do Japão, de Cuba, que criaram o seu design a parti do uso de elementos nacionais". N esse sentido, a exposição que apresentará até 0 dia 24 de agosto é uma "quebra" e um desvio às convenções, mostrando a "cozinha" do artista e, até sua própria mesa de desenho, o palco de suas indecisões e de seu labor. É também o palco de onde saíram marcas e logotipos como os da U Itragás, Metal-Leve, Eucatex, Brasilit, Itaú, Santista, Eletro-Radiobrás, Zanini e Fotoptica, entre outros, numa arte de origem alemã, mas adaptada a uma realidade brasileira." 6
No ano de 1983, fortalecendo a discussão acerca das relações do design gráfico e o seu ambiente, é realizada no Museu a exposição Aloísio Magalhães e o Desenho Industrial no Brasil originalmente realizada por ocasião da inauguração de uma nova agência do Banco Boavista, no Rio de Janeiro, em maio de 1983, que também a patrocinou. A obra de Aloísio Magalhães, como designer artista e planejador cultural, representava a materialização da inventividade brasileira, presente em seu trabalho como designer

“(...) Não se pretende com esta exposição fazer uma análise aprofundada da obra de Aloísio, cuja riqueza visual e multiplicidade de campos de ação não caberia neste espaço. Pretende-se apenas mostrar à po pulação que muitos elementos visuais, que participam de seu cotidiano, são produto da imaginação e do trabalho de profissionais que estão buscando uma harmonia na relação entre homem brasileiro e seu meio ambiente material.

Com esses objetivos, esta mostra é uma homenagem a quem, ligando talento plástico, habilidade técnica, inquietação criativa, pensamento humanista, e ação social, criou, difundiu, e implantou uma nova atividade profissional no Brasil, voltadaaco mpatibilizar o inevitável desenvolvimento tecno ló gico contemporâneo, com o indispensável amadurecimento cultural da nossa população." 7

No ano de 1987, o Museu receberia a exposição SAO - Divisão DESIGN DA DPZ. A SAO, divisão de design da agência de publicidade DPZ, expõe sua produção exposta no MASP com os objetivos de mostrar o trabalho dos seus designers ao público e promover o design aos diversos segmentos da sociedade. A exposição foi também um momento oportuno para a SAO realizar 
uma análise crítica de sua própria produção. E em 1989, conforme já explanado, o Museu homenageia, por meio de exposição organizada pela filha do designer, o trabalho pioneiro de RUBEN MARTINs, fundamental para a consolidação do design gráfico no País. A mostra exibiu a produção do designer, marcas, logotipos, embalagens e produtos por meio de 50 painéis divididos em duas partes: uma cronológica, construindo um itinerário de sua obra outra, reunindo tudo o que não foi possível datar.

As exposições dedicadas ao design brasileiro, localizadas no conjunto de eventos proposto pelo Museu ao longo da gestão de Pietro Maria Bardi, tem como traço comum a problemática da adoção de linguagens estéticas pouco afeitas às características culturais do País em virtude da implantação de modelos internacionais para o desenvolvimento e a consolidação do design no Brasil e, a este período, invocam, em seus discursos, a necessidade de pesquisa em torno do ambiente e da cultura brasileira como fontes primárias de recursos para o desenvolvimento de uma produção original.

\section{N OTAS}

1. MELO, Chico Homem de (Org.). 0 design gráfico brasileiro: anos 60. São Paulo: Cosac Naify, 2006. p. 28.

2. NESBITT, Kate (Org.). U ma nova agenda para a arquitetura: antologia teórica (1965-1995). São Paulo: Cosac Naify, 2006.

3. A contribuição da Olivetti ao panorama do design por meio da sua experiência industrial é fundamentada no diálogo estabelecido com historiador, crítico e curador italiano Enrico Morteo em sua passagem pelo Brasil, em maio de 2009.

4. BARDI, Pietro Maria. Emilie Chamie - trabalhos gráficos fotográficos, programação visual. Museu de Arte de São Paulo Assis Chateaubriand. 15 de julho a 04 de agosto de 1974.

5. KLINTOWITZ/PINTO. Jacob/Zélio Alves. A Censura CheGou ANTES DA TIPOGRAFIA. Isto é, 4 de abril de 1979.

O 'DESIGN' De Wollner, EM EXPosiç̃̃o didática. O Estado de São Paulo, 2 de agosto de 1980

Exposição Aloísio Magalhães e o Desenho Industrial no Brasil. In: Catálogo da exposição Aloísio Magalhães e o Desenho Industria no Brasil. Museu de Arte de São Paulo Assis Chateaubriand, setembro/ outubro de 1983 

Bardi, nas suas palavras, tinha um pallino ${ }^{2}$ na cabeça, vicioso, incorrigível e, ele tinha vários e, entre eles, o interesse na artes plásticas, sem dividi-las entre artes maiores e menores.

E por este pallino que foram organizadas inúmeras mostras no Museu dedicadas à arte e ao artesanato brasileiros, desde a I Exposição de Arte Popular Pernambucana, realizada em 1949, pioneira ao trazer para o Museu peças da cultura popular brasileira. Porém, será definitiva a experiência de Lina no Nordeste brasileiro, região na qual permanecera até 1964, na direção do Museu de Arte Moderna da Bahia, onde também projetaria o Solar do Unhão, para reforçar o pallino, que já acompanhara Bardi, - no qual era perfeitamente possível a convivência dos saberes eruditos e populares - para a consolidação da reflexão em torno da urgência de um inventário da cultura popular brasileira como fundamento para o desenvolvimento de uma produção brasileira original nas suas mais variadas manifestações e, inclui-se aqui, o design.

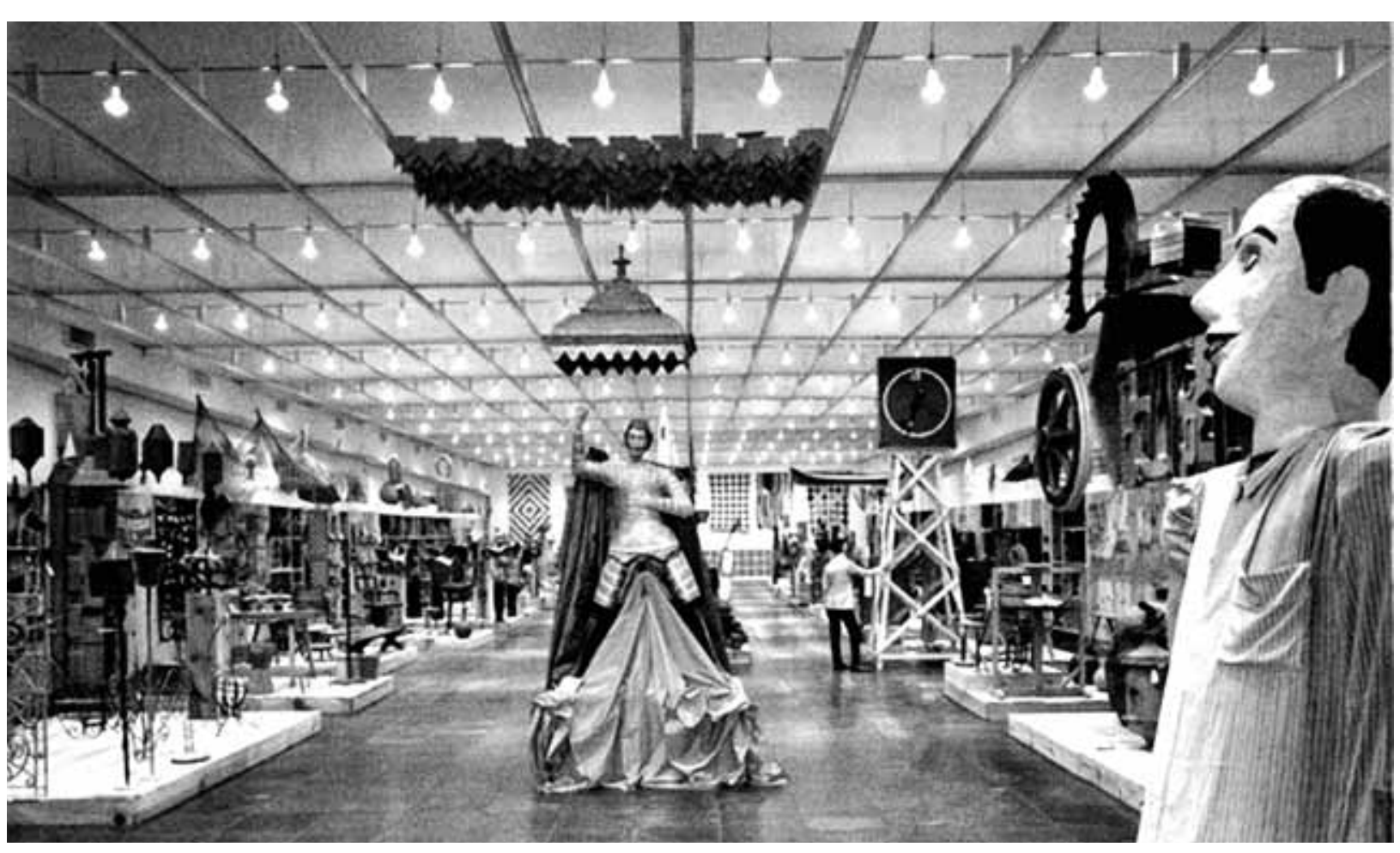

Como anteriormente fora colocado, nas décadas de 1970 e 1980 o design no País ganha dois pólos de significação: o primeiro deles a percepção do design como elemento estratégico e fundamental para a competitividade da produção industrial brasileira e o segundo, na qual este aspecto também é importante, porém a perspectiva amplia-se: o design é também visto como uma manifestação de caráter mais amplo e interdisciplinar, num entrecruzamento de fatores tecnológicos, racionais e comportamento humano aspirações sociais de uma coletividade ${ }^{4}$ com vistas a um aprimoramento do ambiente humano.

Lina Bo Bardi com maior radicalismo, bem como Aloísio Magalhães, fariam parte desta segunda vertente, cuja visão cultura é mais ampla e não codificada pelo vocabulário construtivista internacional, fortemente disseminado pelas instituições de ensino da disciplina no País. Lina, por meio de seus textos, exposições sobre o pré-artesanato e a arte popular brasileira, e fortemente influenciada pelo contato com a cultura popular nordestina apresentará uma extensa e original contribuição à reflexão de bases mais originais à produção do design brasileiro.

E a referida exposição A Mão Do Povo Brasileiro, dedicada a Rodrigo Mello Franco de Andrade, - advogado que ao abandona sua profissão, dedicou-se à criação do Serviço do Patrimônio Histórico e Artístico Nacional em 1937 que, sob sua direção realizou a criação de 20 museus; a produção de 30 revistas e livros; gestão na qual cidades como Olinda, Ouro Preto, Sabará, foram reconhecidas como importantes patrimônios, num trabalho de tod uma existência para a construção de uma civilização brasileira é o primeiro evento, ou ainda, ação efetiva do Museu, constituindo uma notável documentação, para o estabelecimento de novas bases para a história da arte do povo brasileiro.

56 Exposiçāo A Mão do Povo Brasllero 1969 Biblioteca e Centro de D ocumentação do MASP 


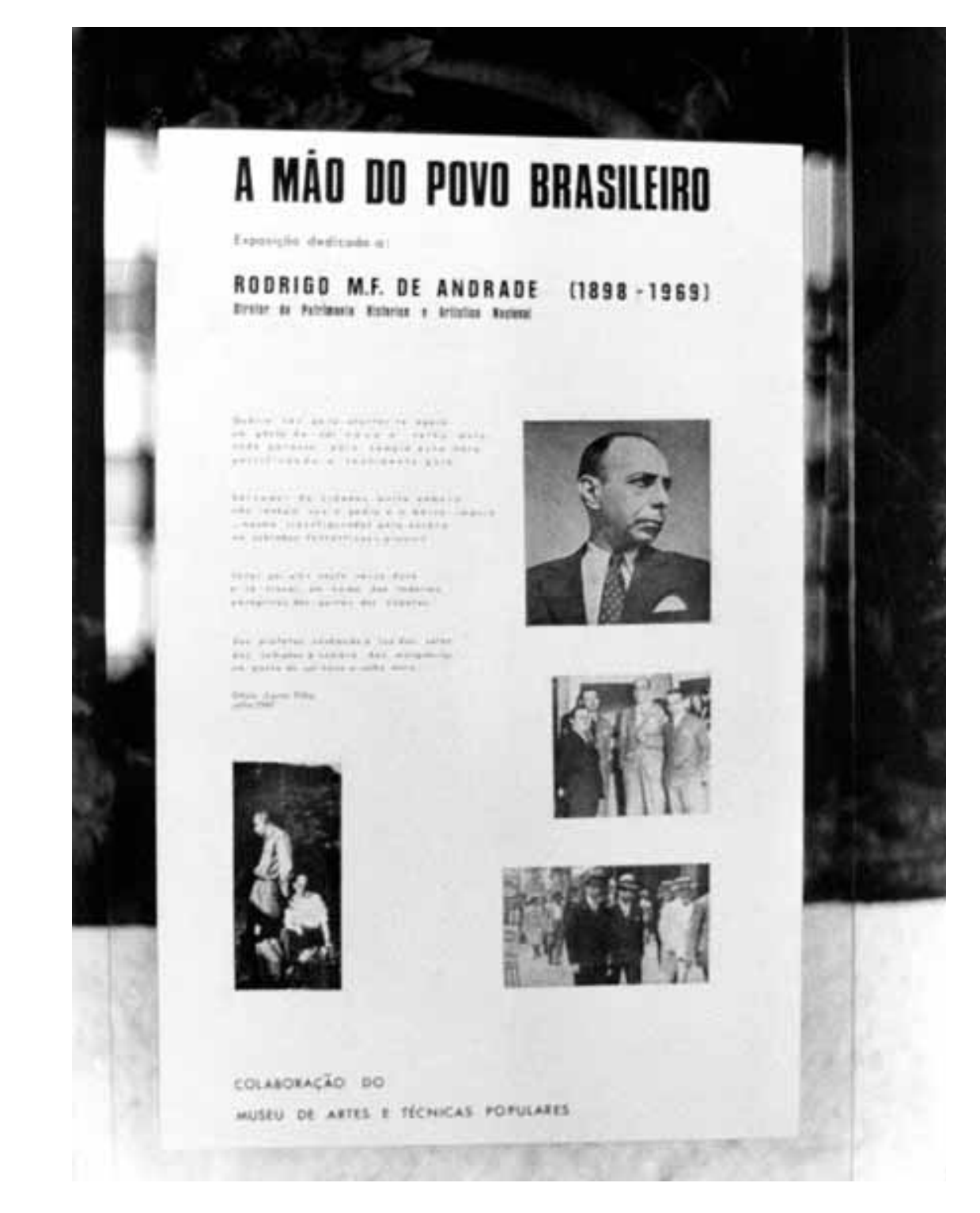

57 Exposiçăo A Mão do Povo de Documentação do MASP

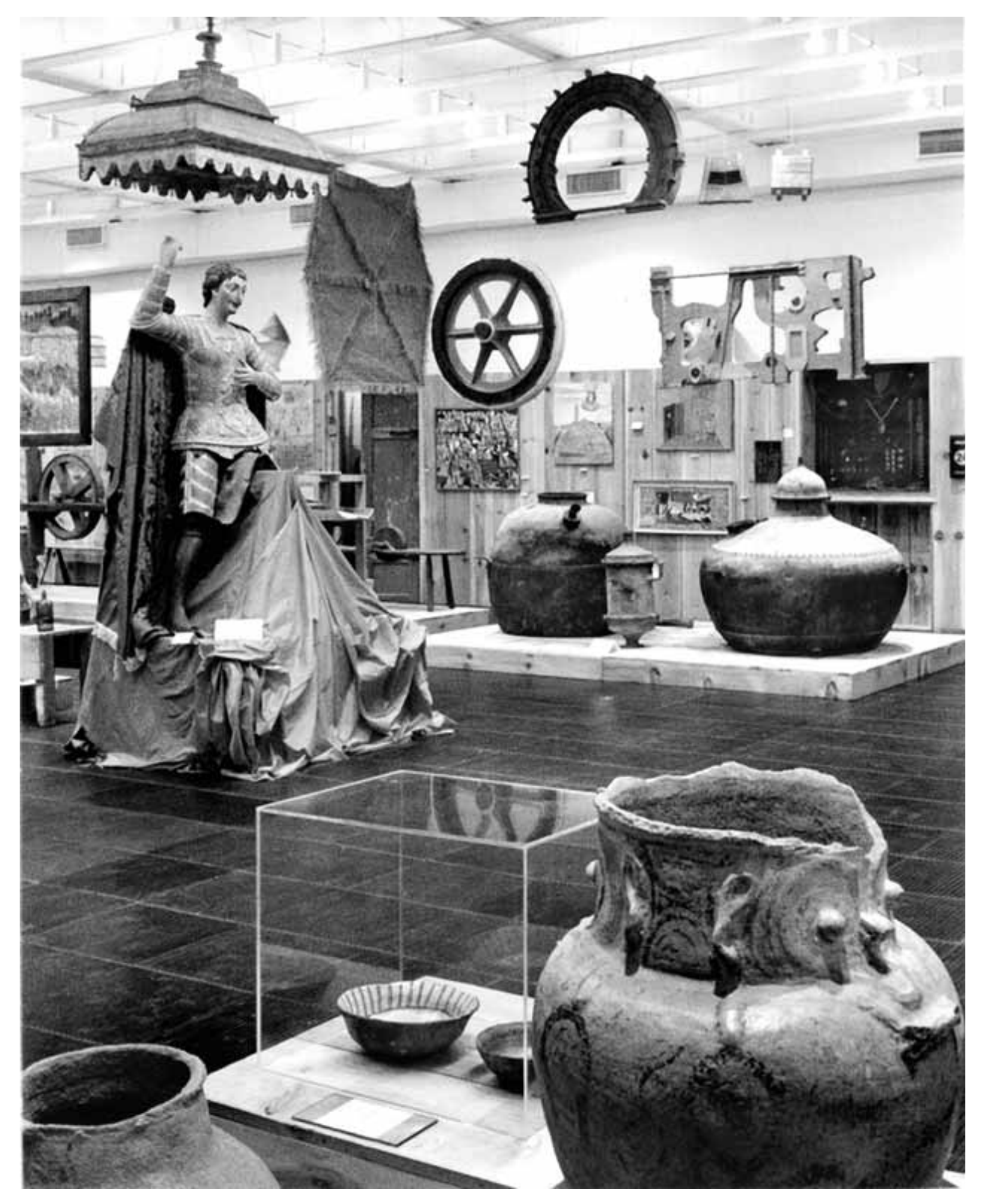


"A primeira grande exposição do Museu de Arte de São Paulo, em sua nova sede na Avenida Paulista, deve ser considerada como um importante subsídio para a sistematização das produções populares brasileiras.

O material apresentado, se tratado objetivamente por aqueles que se interessam por este setor das Ciências Humanas, constitui notável documentação, para o estabelecimento em novas bases, de uma história da arte do povo do Brasil. Trata-se, como se sabe, da própria memória nacional, condição essencial para a continuidade da cultura, sofrendo rápida e irreversível desintegração, pela simples falta de registros, de obras e agentes. É claro que apenas o cadastramento dos fatos seria inútil. Há que se situar os objetos de arte (e tudo aquilo que é manufaturado com liberdade assim deve ser chamado) em seu complexo sociocultural descobrir a função que exercem no grupo, explicando suas origens e relação com o meio.

Fugindo aos conceitos que se fizeram tradicionais, por uma crítica estranha ao pensamento contemporâneo, de "Arte", "bom-gosto", "mau-gosto" e comunicação com o público, esta mostra apresenta o que se fez no Brasil nos últimos duzentos e cinquenta anos, em matéria de criatividade. Não pretendendo esgotar o assunto, nem aspirando ao enciclopedismo, procurouse reunir uma amostra significativa das várias regiões do Brasil $\mathrm{e}$ recriar o espaço social onde os fatos estavam inseridos. A cronologia, no caso, era perfeitamente dispensável, em consequência do tipo de abordagem adotada.

A montagem de Lina Bo Bardi é despojada, e, portanto, humanizada; dispostos sobre o lenho nu do pinho, os objetos se mantém livres de qualquer interferência formal, envolvidos apenas pela onipresença pressentida dos autores. Assim, poder-se-á constatar a assombrosa magia dos ex-votos, ingênua monumentalidade das carrancas-proas do S. Francisco, as milenares ferramentas do mobiliário, o equipamento doméstico, a rusticidade eficaz das máquinas, o terror do cangaço, a literatura de cordel, o teatro de bonecos (Mamulengos) do Nordeste e sua crítica, e, sobretudo, o homem do Brasil, dos pequenos povoados e no isolamento das grandes cidades, na sua tenaz, e nem sempre bem sucedida, resistência àquilo que o oprime; a violenta e, não raro, comovente ação de reintegrar para modificar o seu universo.

As peças são, quase sempre, feitas para consumo imediato. O indivíduo não se destaca, em proveito do sentimento comunitário muito mais forte; as peças quase nunca são assinadas ou datadas, dada a inutilidade desta marca, por uma série de fatores incluindo a imediata utilização do objeto e consequente perecimento. Isso só irá acontecer quando o trabalhador, entrando em contato com a sociedade urbana, for solicitado por um mercado que $\mathrm{o}$ absorve cujos padrões estéticos nunca vão de encontro às suas necessidade de expressão. Cedo, seus trabalhos, agora já assinados, irão figurar em alguma galeria, perdendo assim gradativamente a purez inicial, o artista distanciando-se de seu trabalho, provavelmente transformando-se em "Primitivo". Sua arte se transformará em mercadoria, e ele, um produtor de mercadorias, irá depender de um mercado anônimo de consumidores, chamado público, e subordinado cada vez mais às leis da competição. Muitos têm caído, dessa maneira, em desgraça.

A matéria prima da confecção, além daquela impalpável, a mesma que impulsionou o último dos grandes macacos a arranca um galho de árvore e transformá-lo em arma, executando assim o primeiro ato de cultura e iniciando a longa aventura humana, é em grande parte constituída pelo "lixo cultural", isto é, aquilo que a sociedade industrial (onde tudo se torna obsoleto com incrível rapidez), joga fora. São pneus velhos, latas de produtos de amplo consumo, sucata trapos, material de demolições, que o artista com sua sensibilidade e forte senso de poupança (nem tudo é azul), colhe e reutiliza.

Uma das peças de maior significado da exposição é um pequeno avião, feito de material do mesmo gênero, encontrado em Pernambuco. Quem o fez, membro desta legião de maravilhosos 
desconhecidos, imaginava que lá no alto, região inatingível, exceto por seus sonhos, havia gente que movia as hélices, trepados nas asas daquela estranha máquina, que sempre via passar. Este monumento, poética manifestação da vontade de ir um dia quem sabe, até as estrelas, poderá desaparecer com tudo mais aquilo que nosso equivocado século ameaça destruir.

Mostrar estas coisas, da forma como está sendo feito, poderá impedir que isto aconteça, ou pelo menos tornar mais lento o processo."5

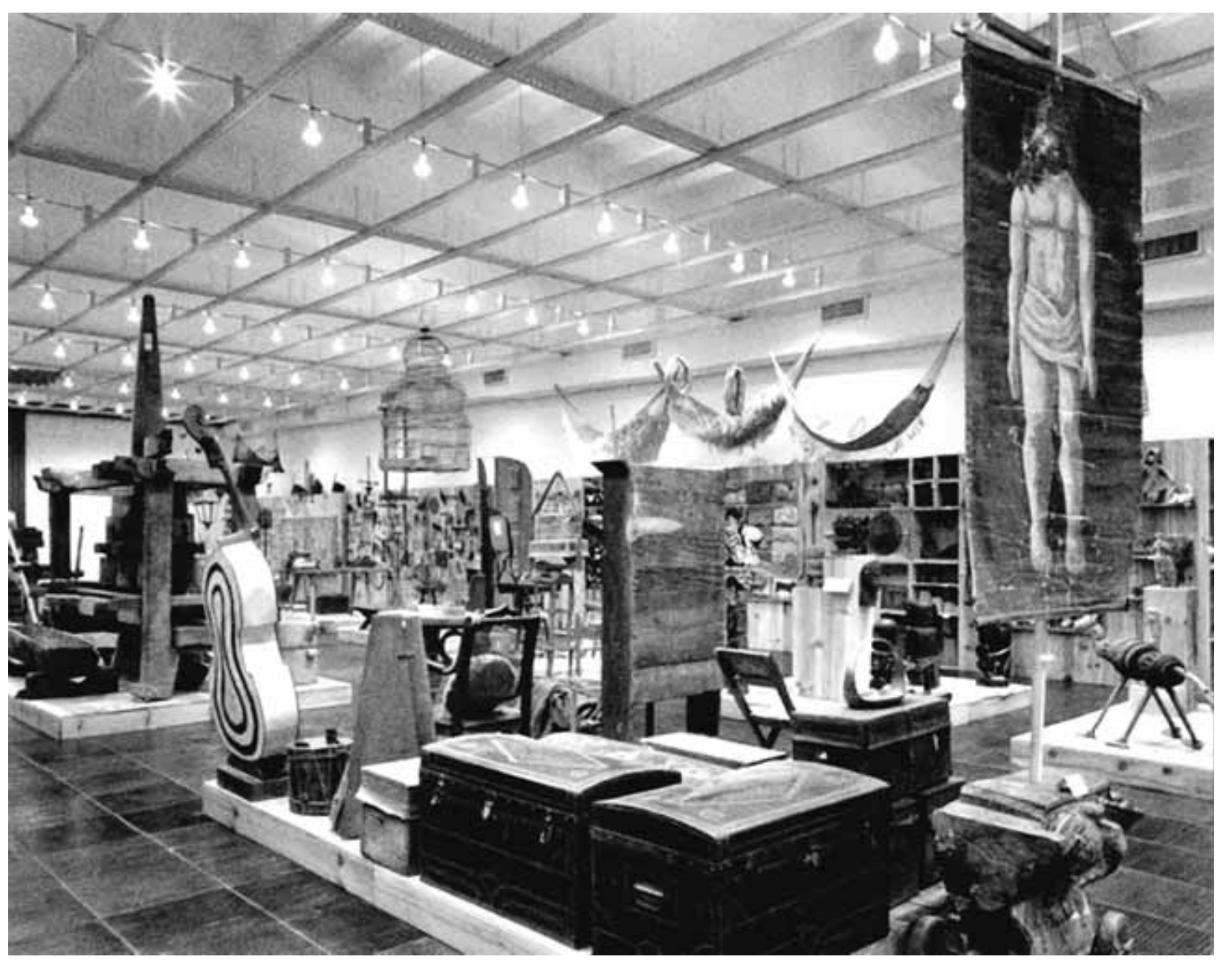

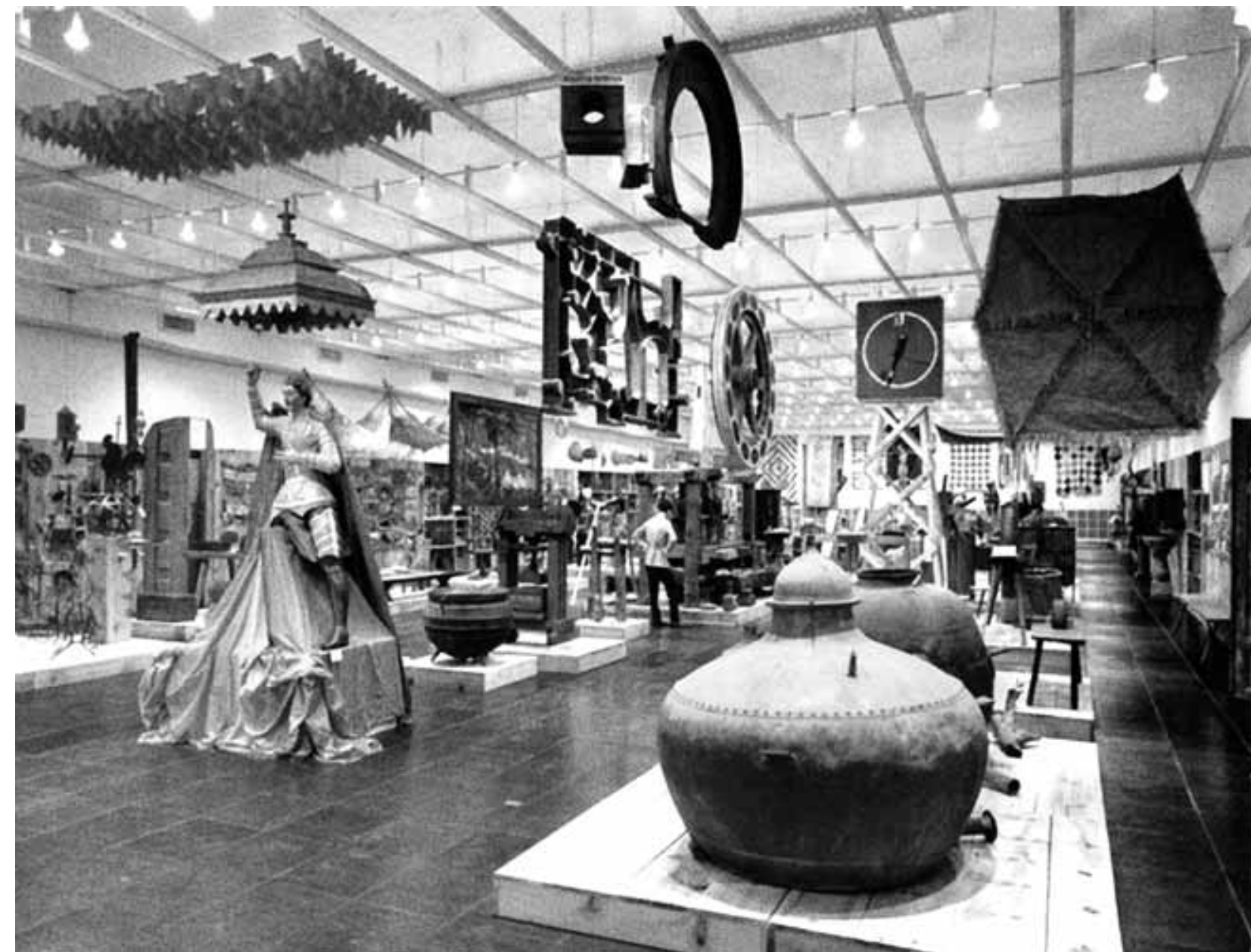

É para esta necessária sistematização de informações sobre a cultura brasileira, suas técnicas, história e estética que Lina Bo Bardi chamará a atenção dos designers:

59 Exposiç̄a A Mão do Povo de Documentação do MASP

60 Exposiḹão A MÃo do Povo BRASLLERO 1969 Biblioteca e Centro de Documentação do MASP
"O reexame da história recente do País se impõe. 0 balanço da civilização brasileira "popular" é necessário, mesmo se pobre à luz da alta cultura. Este balanço não é o balanço do folclore, sempre paternalisticamente amparado pela cultura elevada, é o balanço "visto do outro lado", o balanço participante. É o Aleijadinho e a cultura brasileira antes da Missão Francesa. 
E o nordestino do couro e das latas vazias, é o habitante das "vilas", é o negro e o índio, é uma massa que inventa que traz uma contribuição indigesta, seca, dura de digerir.

Esta urgência, este não poder esperar mais, é a base real do trabalho do artista brasileiro, uma realidade que não precisa de estímulos artificiais, uma fartura cultural ao alcance das mãos, uma riqueza antropológica única, com acontecimentos históricos trágicos e fundamentais. 0 Brasil se industrializou, a nova realidade precisa ser aceita para ser estudada. A "volta" a corpos sociais extintos é impossível, a criação de centros artesanais, a volta a um artesanato como antídoto a uma industrialização estranha aos princípios do país é errada. Porque 0 artesanato, como corpo social, nunca existiu no Brasil, o que existe é um pré-artesanato doméstico esparso, o que existiu foi uma imigração rala de artesãos ibéricos ou italianos e, no século XIX, manufaturas. A rtesanato, nunca.

0 levantamento cultural do pré-artesanato brasileiro podia ter sido feito antes de o país enveredar pelo caminho do capitalismo dependente, quando uma revolução democrático-burguesa era ainda possível. N este caso, as opções culturais no campo do Desenho Industrial podiam ter sido outras, mais aderentes às necessidades reais do país (mesmo se pobres, bem mais pobres que as opções culturais da C hina e da Finlândia).

Precisa recomeçar saindo de uma nova realidade, mas uma coisa está hoje bem clara e definida: os que se ocupam das necessidades de uma parcela bem reduzida da sociedade, os autores da serena tomada de anotações dos fatos, os que não fazem escândalo, estão com certeza, de outro lado. 0 erro é querer eliminar a realidade coletiva em nome da estética, custe 0 que custar. Todas as revoltas e as vanguardas 61 Exposiç̧̄o A Mão do Pova de D ocumentaçãa do MASP a integração do Kitsch também. 0 verdadeiro Kitsch, o da empáfia cultural da burguesia alemã entre 0 fim do século XIX e 0 XX, e 0 Kitsch político de Hitler são irrecuperáveis. Importante é aceitar, fazer uso antropológico, quando necessário, de coisas esteticamente negativas: a arte (como a arquitetura e o desenho industrial) é sempre uma operação política." 6

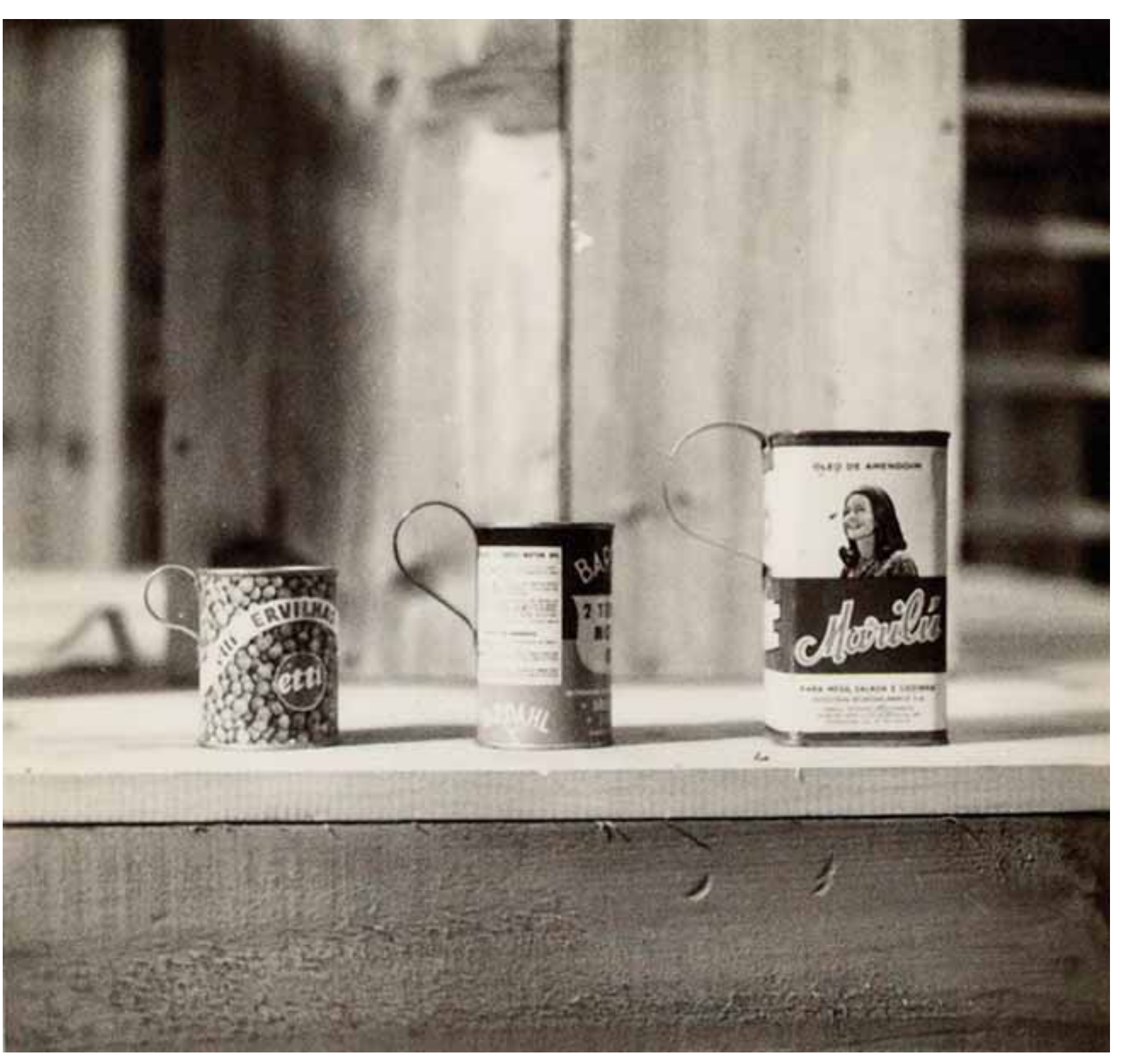


A Mão do Povo Brasileiro é, assim, de alguma maneira e, nas palavras de Lina, o reconhecimento da falência da utopia moderna, na medida em que o projeto modernista limitou-se, no contexto americano, à manipulação de um vocabulário estético foi incapaz de minimizar os contrastes sociais no País. Vale lembra que Lina traz ainda consigo a experiência das reflexões italianas desenvolvimento do design italiano não estabeleceria uma ruptura com a manufatura artesanal de alta qualidade, mas é justamente, a partir do reconhecimento deste saber, que a produção industria é potencializada

A apresentação da produção pré-artesanal brasileira na exposição não tem como objetivo uma ênfase, um retorno, aos processos produtivos artesanais como caminho para o desenvolvimento do design no País, mas à maneira da experiência portuguesa para o campo da arquitetura, na qual Fernando Távora conduziria, aind na década de 1950, um extenso levantamento das características da arquitetura vernácula portuguesa para, a partir daí, formar uma escola de arquitetura moderna atenta aos aspectos regionais do País - é o que Lina propõe ao design brasileiro.

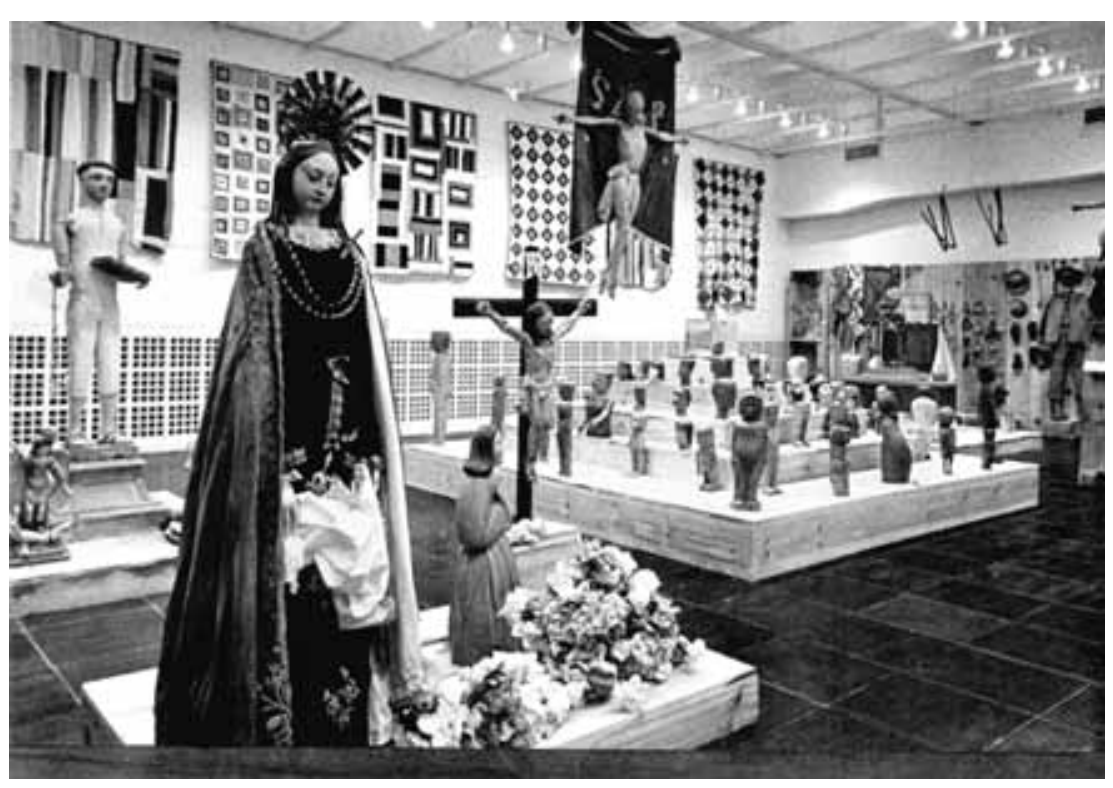

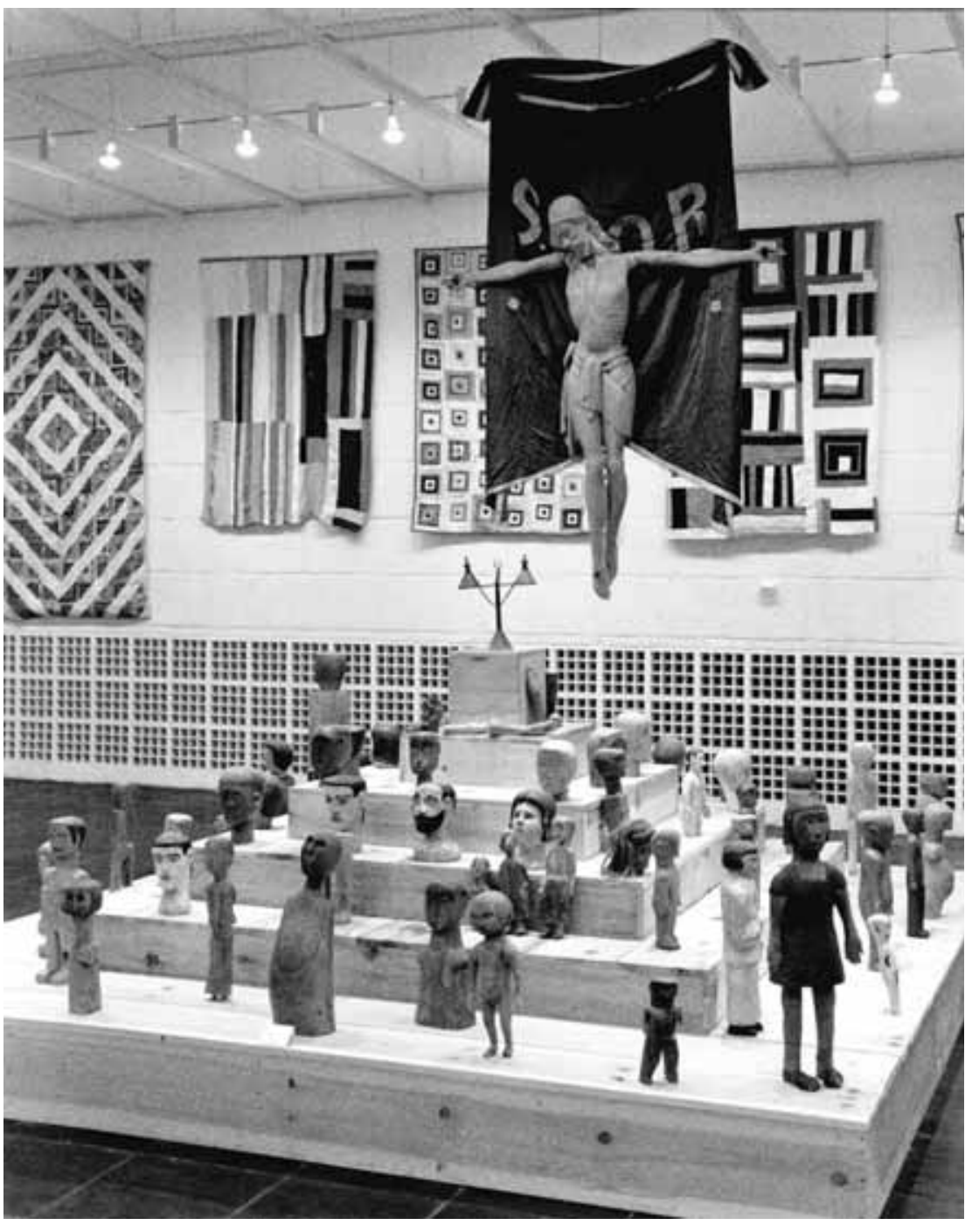

É possível afirmar que, embora Lina Bo Bardi não tenha feito parte do grupo dos tropicalistas, seu pensamento a enquadraria no universo conceitual do movimento registrado na cultura brasileira entre 1967 e 72, cujo objetivo era articular um ideal de nação - concebido em função da revalorização das "raízes" culturais do exercício da liberdade de expressão em clara oposição ao projeto ideológico e político dos militares. ${ }^{7}$ Certamente influenciada pelo movimento e principalmente por meio da amizade com José Celso 
Martinez Corrêa, que, juntamente com Caetano Veloso e Hélio Oiticica, foram os representantes mais conhecidos do movimento, é inegável que as ideias de Bo Bardi sobre o design apresentem claras relações às propostas defendidas pelos tropicalistas. ${ }^{8}$

Oreconhecimento dolegado cultural do povo brasileiro como ponto de partida para o desenvolvimento de uma produção brasileira original foi o tema da exposição A Mão do Povo Brasileiro, porém pouco se sabe das inúmeras atividades empreendidas pelo MASP nos anos seguintes, nas quais o Museu colaborará de forma intensa à consolidação de uma ampla contribuição ao debate e legado à documentação da arte popular brasileira.

Em 1975, após exibição no Museu de Arte Moderna do Rio de Janeiro (MAM RJ), o MASP receberia em seu espaço a produção de móveis na INDIVIDUAL José ZANine CALDAS. Baiano de Belmonte, hábil artesão, nas palavras de Lúcio Costa, "um dos pouco intelectuais que, paradoxalmente, chegaram à profissão pelo caminho direto da prática dos ofícios e do artesanato." ${ }^{9}$ A mostra teve como objetivo principal demonstrar novamente, por meio do trabalho de Zanine, a possibilidade de criar objetos a partir da ideia de uma "estética brasileira", na qual o uso de materiais e elementos da cultura nacional são predominantes.

Em continuidade ao discurso, no início da década de 1980 mais precisamente em 1981, o Museu causaria polêmica ao receber em suas salas fantasias e objetos de uma escola de samba na Exposição Fantasias de Carnaval da Escola de SAmba Pérola Negra. E é Pietro Maria Bardi que justifica a acolhida da instituição às fantasias e artefatos populares:

"O MASP é um museu aberto. Já fizemos desfiles de moda na pinacoteca e achamos interessante mostrar todas as manifestações populares, independentes de outras atividades do museu. N ão é porque promovemos, futuramente, uma exposição com obras de Miró, Magritte e Max Ernst, que devemos esquecer a arte essencialmente popular. Esta exposição de fantasias revela aspectos muito interessantes, como a maneira de se confeccionar as roupas, as alegorias, enfim, como o povo trabalha para fazer seu Carnaval. Tem um caráter estritamente didático e documental."

No mesmo ano, 1981, uma reedição da já referida exposição A Mão do Povo Brasileiro é solicitada a pedido da Fundação Bienal que receberia a visita dos Conselheiros Internacionais do Museu de Arte Moderna de Nova Iorque (MOMA - NY), reunidos em São Paulo para sua convenção anual. A solicitação evidencia a importância e o impacto que a exposição tivera em 1969 para o debate da arte no País. Sob o título de A ArTe Popular do Brasil, são novamente apresentados os mais variados objetos de produção popular ao lado de peças utilitárias como alambiques, instrumento de trabalho e de uso. Tratava-se de uma oportunidade única para apresentar ao público internacional os aspectos mais característicos da arte popular brasileira. 


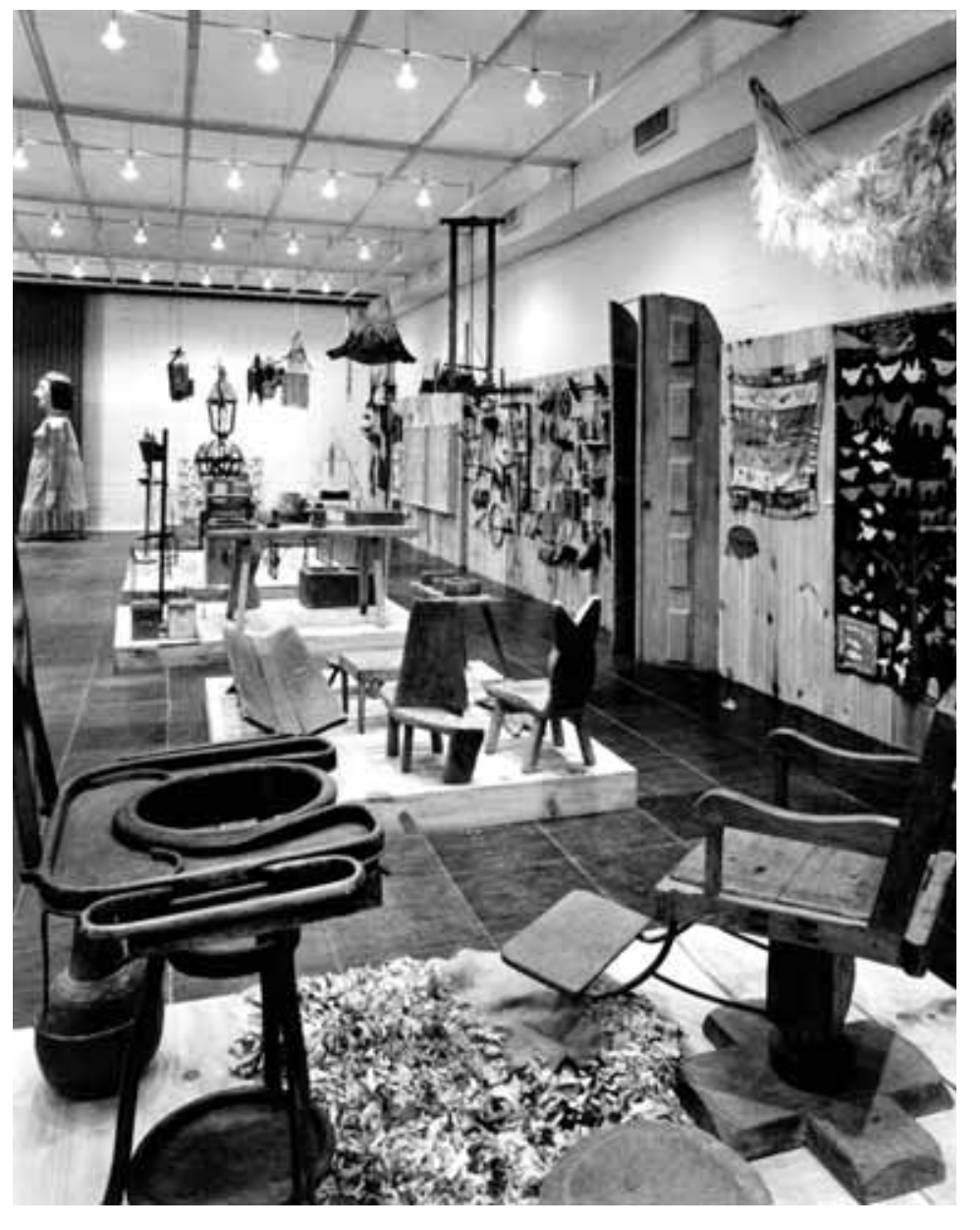

Em 1982, agora por ocasião da inauguração da Fábrica da Pompeia, o SESC Pompeia, cujo projeto de restauro do espaço também de Lina Bo Bardi, o MASP elaboraria a exposição O Design no Brasil - História e Realidade para o SESC, por meio do convênio da instituição com o Museu. A exposição completa e soma-se à, já citada, mostra organizada no Museu ano antes, A Mão do Povo Brasileiro. A partir do entendimento do design enquanto produção de objetos - artesanais e industriais - diferenciados seja pela funcionalidade, singularidade estética, genialidade ou inventividade; a exposição reuniria, mais uma vez, 65 Expo sil̆à̃o A Mão do Povo e Documentaçâa do MASP centenas de peças e materiais inéditos, frutos da operosidade popular como iniciativa para a consolidação de um inventário

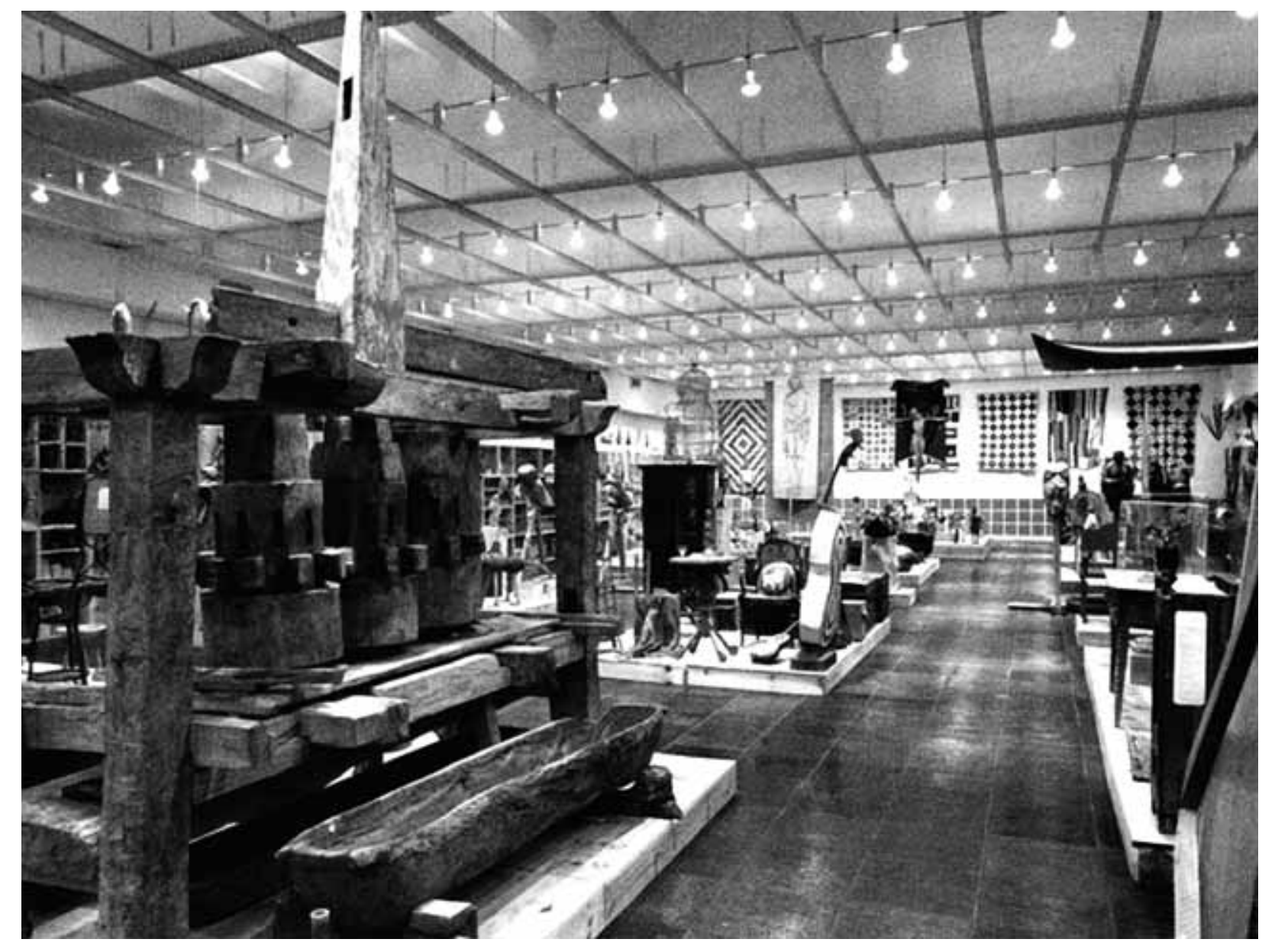

da cultura popular brasileira. Em texto publicado na revista Senhor, é possível tomar contato com o debate da época, por meio das palavras de Lina à crítica que apontara a exposição como saudosista:

“(...) E, principalmente, existem atitudes como a da arquiteta Lina Bo Bardi, que reagiu sutilmente às virulentas críticas contra a exposição na fábrica da Pompeia, acusada de saudosista. Ela acha que é preciso refletir sobre o que aconteceu com o design no Brasil para que no futuro as exposições não sejam tão contundentes como esta. E responde com um pequeno texto,àmaneira de G lauber Rocha (sem,entretanto, 
conter sua agressividade), homenageado por ela na exposição, com uma cadeira de viajante feita, por coincidência, em 1964:

"E o tempo passou. Aquilo que era Analyse Rigorosa passou a ser chamada de Demagogia, e o esforço coletivo para um Melhoramento O rgânico (Desenvolvimento) passou a ser a meta duma mentalidade estratégica que "esquadrinha o ambiente para técnicas do Desenvolvimento 0 rganizacional". Sim, essa é uma Exposição terrivelmente saudosista, uma homenagem aos que morreram na tentativa de uma analyse real. E um seco convite (contra as posições 'abaixo do óbvio') para uma nova tomada da consciência coletiva. A 'ingenuidade' desta exposição poderá ser a prova da sua validade. É aquilo que Pasolini chamava de 'Semiótica da Realidade'."

Num sussurro, Lina Bo Bardi completa o pensamento exposto neste pequeno texto:"As águas estão muito paradas. Elas precisam ser sacudidas." 11

As iniciativas do Museu não parariam aí. Por meio de parcerias com as empresas Rhodia, Du Pont e Cia. Suzano de Papel e Celulose, MASP exibiria diversas produções de caráter artesanal com o objetivo de reconhecimento da experiência popular brasileira. Tecidos de Minas, em 1982, é uma dessas iniciativas. O evento oi parte de uma estratégia de promoção da cultura brasileira pela Du Pont do Brasil, como demonstram as palavras de Ingrid Wahle, do setor de Imprensa e Relações Públicas da empresa:

"Como a experiência foi muito bem-sucedida, com grande afluência de público, (refere-se aqui a uma exposição dedicad à cerâmica produzida no Vale do Ribeira apresentada no ano anterior) percebemos que podíamos absorver como projeto anual a tarefa de patrocinar uma mostra de arte popular, sempre com a preocupação de eleger produções ligadas às raízes culturais brasileiras. E, principalmente, de regiões carentes, cujo trabalho é pouco divulgado e conhecido.Assim além do retorno institucional da promoção para a empresa essas mostras levariam a essas comunidades o retorno real da venda de seus produtos e o respeito e conhecimento de seus trabalhos por outros centros". 12

No ano seguinte, 1983, a empresa patrocinaria a exposição Bordados da CaAtinga do Piauí, realizada no Museu, reiterando as iniciativas da Du Pont, conjuntamente com o MASP, no incentivo à difusão da arte brasileira. A partir da reunião de três mil peças bordadas na região de São Raimundo Nonato no sertão do Piauí, bordadas, sobretudo, por meninas entre 7 e 14 anos como atividade de sustento das suas famílias, a iniciativa não se limitou somente a exibição, foi além: as peças expostas puderam ser adquiridas durante a exposição com a renda revertida em benefício dos próprios produtores locais.

Retornando ao ano de 1982, a exposição Criando PApéis do Artista Otavio Roth, patrocinada pela Cia. Suzano de Papel e Celulose, pode ser incluída no mesmo discurso. Otávio Roth, artista multidisciplinar, dedicava-se à pesquisa sobre a fabricação de papéis e é quem fundou no Brasil a primeira fábrica de papéis artesanais. A partir da consideração do processo de fabricação do papel como arte, a exposição apresentou o processo de execução dos papéis por meio de painéis e também um conjunto extensivo de sua obra, representado por aproximadamente trinta quadros com folhas de cada tipo.

Em 1984, o Museu abrigaria novamente três exposições dedicadas à produção a partir de processos artesanais: ARTESANATO EM COURO exibiu trabalhos de gravação em couro executados por Shizuko Takeno e seus alunos. Shizuko contribuiu para a popularização da arte de gravação no Brasil, com a difusão do estilo pirografado 
- técnica de gravação a fogo; as exposições Bonecos DE PANO; Artesanato em Madeira; Joias Artesanais e Exposição BATIK - todas parte do programa "Feito em Casa" organizado pela Secretaria Municipal de Planejamento (SEMPLA) com o objetivo de atender a desempregados e aos pequenos e inúmeros produtore domésticos de São Paulo, numa tentativa de ajudá-los a viver das suas próprias criações.

Com a exposição e obra TrançAdo Brasileiro, realizada m 1985, a Rhodia, conjuntamente com o MASP, iniciaria uma nova fase na editoração de seus livros, com projeto gráfico de Jacob Klintowitz, fotos de Lew Parrela, Mário Cravo Neto e Rômulo Fialdini; esta primeira iniciativa surge com o objetivo de estimula e documentar a arte popular - a partir do registro da produção de cestas, esteiras, redes e peneiras de índios do Amazônas, Pará Maranhão e Mato Grosso; trabalhos dos estados do Nordeste produções de Minas Gerais, Goiás e interior de São Paulo e criações litorâneas do Centro-Sul e Espírito Santo, Rio de Janeiro, São Paulo, Paraná, Santa Catarina e Rio Grande do Sul; incluindo obra dos índios guaranis - foi o ponto de partida para a formação de uma coleção de Arte Popular Brasileira, por meio do registro do trabalho de artesãos brasileiros como homenagem àqueles que, com uas mãos, construíam peças de belíssima plasticidade e com grande função social e utilitária. A exposição MÁscaras Brasileiras realizada no Museu seria o tema do Projeto Cultural Rhodia do ano de 1986.

No ano de 1986, o Museu receberia a importante exposição ARTE Do Povo BrasileIro, dedicada a exibir a coleção de Jacques Van de Beuque, arquiteto francês, que iniciara sua coleção de arte popular brasileira nos anos 1950, quando, numa de suas viagen a Recife, conhecera o mestre Vitalino, cuja obra fora exibid no MASP, já em 1949, na primeira exposição dedicada à arte popular nordestina. Parte deste acervo fora antes apresentada no Museu de Arte Moderna do Rio de Janeiro (MAM RJ), em 1976, e pela Fundação Roberto Marinho, no Rio de Janeiro, em 1983.
Hoje é esta coleção que forma o maior acervo de Arte Popular Brasileira, abrigado pelo Museu do Pontal, no Rio de Janeiro.

Nos últimos anos da gestão de Pietro Maria Bardi, em 1988, um das últimas manifestações realizadas com objetivo de valorização e preservação da arte popular brasileira foi a exposição A MALOC MARÚBO, na qual artefatos indígenas foram apresentados com o objetivo de preservar e divulgar a arte indígena.

Pietro Maria Bardi se afastaria do cargo de diretor-conservador em 1989, sucedido por Fábio Magalhães, e Lina faleceria em 1992 encerrando no Museu um longo período dedicado à construção de um inventário da cultura popular brasileira. Entretanto, se nas palavras de Lina, a documentação deste legado era a opção mais acertada para o desenvolvimento de um design brasileir mais atento a sua realidade; nos últimos anos da década de 1970 durante toda a década de 1980, o país entraria em uma forte recessão, cuja escassez de recursos permitiu que muitas dessas ações engendradas, sobretudo no ambiente industrial, perdessem suas forças. A alternativa proposta ao longo desse extenso debate revelado pelas exposições, mais ampla e complexa, somente se desenvolveria por meio de uma ampla atuação do Estado, de uma atuação política. Porém, é justamente a partir da década de 1980 que o Estado abandonaria seu papel de planejador e passa a estar completamente absorvido pelos pagamentos de juros e pelas tentativas de controle dos altos índices de inflação e, portanto, incapaz de atuar como articulador de um projeto de desenvolvimento abrangente para o País. ${ }^{13}$ 


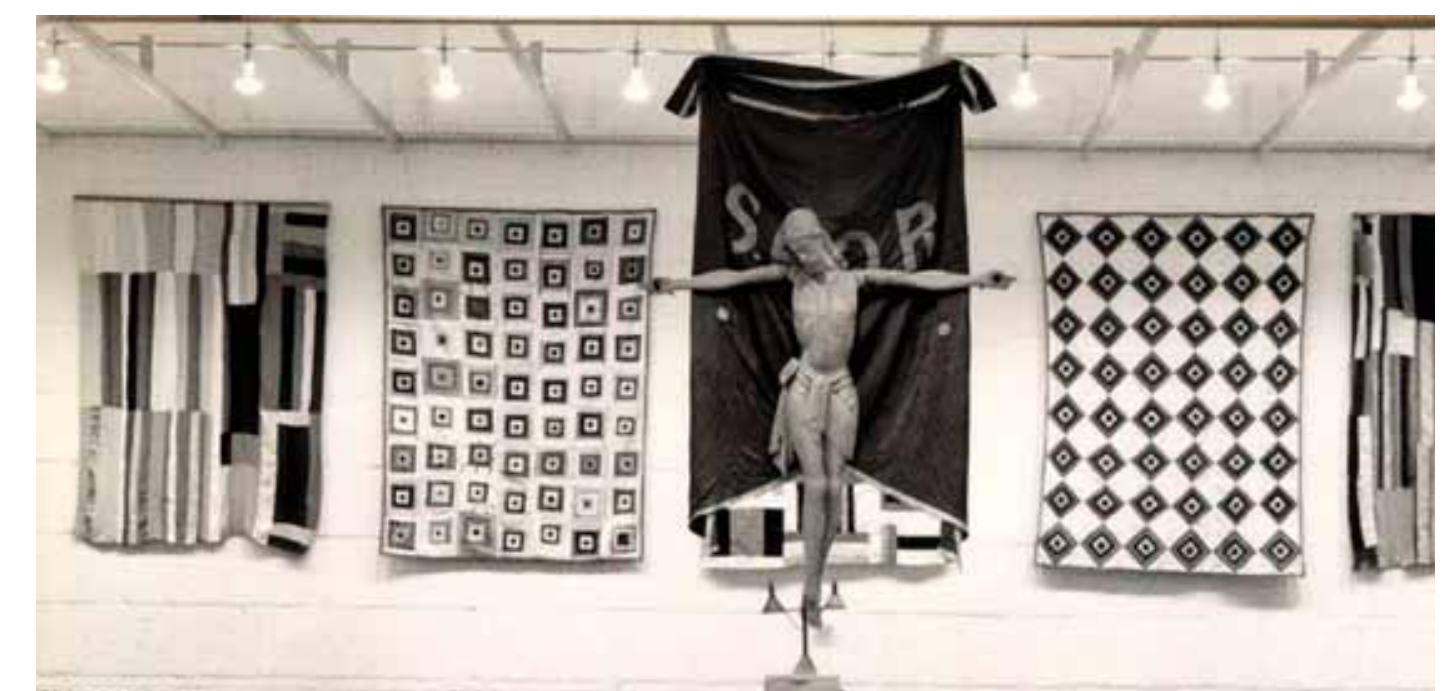

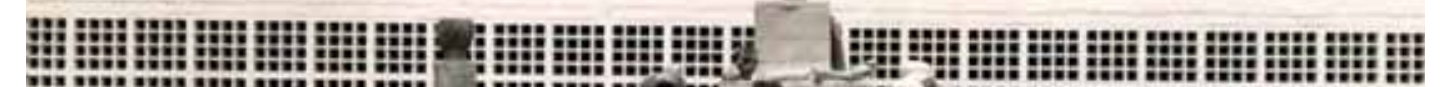

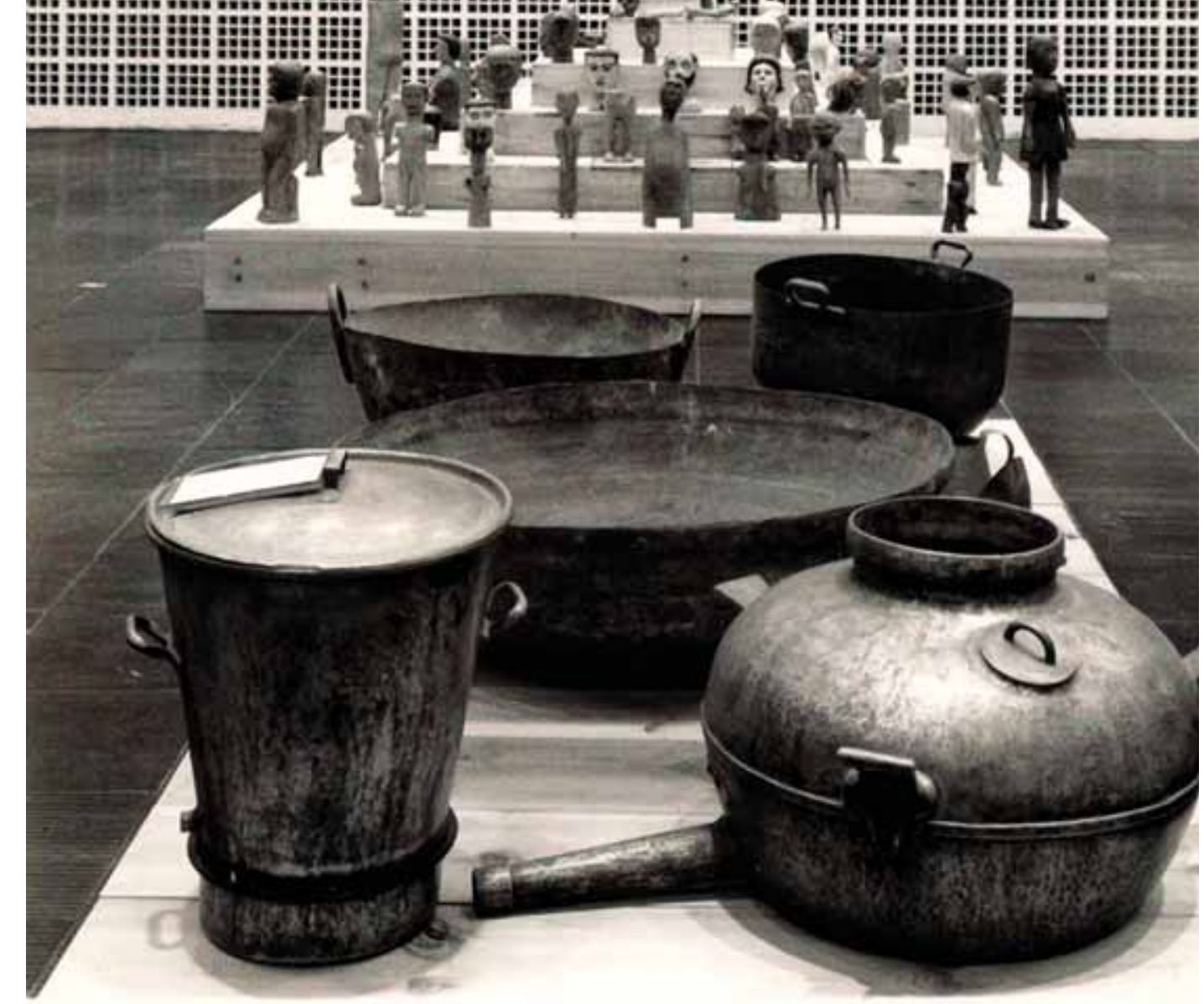

NOTAS

1. KLINTOWITZ, Jacob. 0 D esign no Brasil, um grande momento no Sesc. O Estado de São Paulo, 17 de abril de 1982.

2. Pallino, na gíria italiana, refere-se a quem se interessa por um determinado assunto.

3. BARDI, Pietro Maria. Sem a ajuda dos críticos. Senhor nº266, 22 de Abril de 1986.

4. Discurso proferido por Aloísio Magalhães durante os simpósios da 29a reunião anual da Sociedade Brasileira para o Progresso da Ciência (SBPC) realizado em São Paulo. In: LONDON, Valéria Munk. A contradição entre criatividade e a importação de tecnologia - o dilema do desenho industrial brasileiro. Jornal do Brasil, 25 de julho de 1977.

5. A Mão do Homem Brasileiro: como fazer as coisas sem ter com que além de si próprio. Texto transcrito do arquivo da exposição pertencente ao Centro de Documentação do MASP.

6. BARDI, Lina Bo. Planejamento ambiental: "desenho" no impasse Malasartes, Rio de Janeiro, nº2, dezembro-fevereiro 1976.

7. BASUALDO, Carlos. Vanguarda, cultura popular e indústria cultural no Brasil. BASUALDO, Carlos (org.). São Paulo: Cosa Naify, 2007. p.11-28.

8. CARA, Milene. Do Desenho Industrial ao design no Brasil: uma bibliografia crítica para a disciplina. São Paulo: Blucher, 2010.

9. Zanine, o homem que ainda faz coisas. Jornal da Tarde, 28 de outubro de 1975. 
10. Depoimento de Pietro Maria Bardi. In: Carnaval vira peça de museu. Folha de S. Paulo, Ilustrada, 12 de março de 1981.

11. Design: enfim, uma polêmica. Revista Senhor $\mathrm{n}^{\circ} 61,19$ de maio de 1982, p. 62 - 64.

12. D os teares de Minas para o Museu. O Estado de São Paulo, 1982.

13. CARA, Milene. Do D esenho Industrial ao design no Brasil: uma bibliografia crítica para a disciplina. São Paulo: Blucher, 2010

\section{O N C LUSÃ O}

Os fios que tecem a trama: o desenlace que enlaça a definição de Design

Escrever Difusão e Construç̃o do Design no BrasLl: O PAPEL do MASP foi, à maneira do texto de dissertação de mestrado, Do DESENHO INDUSTRIAL AO DESIGN - UMA BIBLIOGRAFIA PARA A Disciplina, um grande desafio. Adentrar mais uma vez ao território do design, assolado pela ausência de sistematizações historiográficas e modelos analíticos com as corretas condições para evidenciar a complexidade do campo, bem como suas motivações antropológicas, é, a um só tempo, tarefa relevante e arriscada.

Se a relevância do tema levou-me à inicial pretensão em reconhecer quase que a totalidade das atividades expositivas dedicadas ao campo no Brasil, o risco desta iniciativa mostrou-se de imediato a enorme quantidade de exposições demonstrou a impossibilidade a execução de tal tarefa, que demandaria um esforço inviável aos limites da pesquisa à qual este texto dedica-se.

Por outro lado, foi justamente o feliz encontro com a vasta atividade expositiva, sobretudo do Museu de Arte de São Paulo, o MASP sob a direção de Pietro Maria Bardi, ao lado de Lina Bo Bardi, que demonstrou a importância do discurso das exposiç̃es enquanto importante reflexo do pensamento de uma época. E dessa forma, esta abordagem também passa a constituir uma importante metodologia para a elaboração de uma historiografia da disciplina contribuição fundamental, dada a carência de sistematizações eficientes para o campo. E foi a partir da apresentação e análise os principais temas recorrentes no discurso das exposições que se entou extrair os fios que tecem a trama proposta pelo Museu par difusão e construção do campo de design no País.

é o primeiro fio desta trama, localizado nas atividades expositivas que precedem as demais, que traz consigo uma visão que perpassará todo o conjunto de iniciativas elaboradas pelo MASP para o 
design: o entendimento do objeto de uso ordinário seja artesanal ou industrial enquanto elemento de arte. É por meio dos valores históricos, técnicos e estéticos que os saberes da arte e do design aproximam-se, enquanto resultado de uma profunda compreensão dos variados aspectos de uma sociedade.

O segundo fio reitera esta convicção à produção visual, porém inicia o traçado de novas ambições do Museu - ambições didáticas. Ao somar à tradicional configuração expositiva, restrita ao espaço do salão, atividades de palestras, exibições de filmes, visitas externas a gráficas e aulas, anteciparia, já em 1949, o interesse da instituição na formação de profissionais para o campo no País, que culminará na criação do IAC, no ano de 1951.

O terceiro fio, surpreendente, na medida em que traz para o espaço expositivo os fios que materialmente tecem costumes nas oficinas criadas no espaço do Museu, propõe a visão da moda enquanto arte e moda enquanto tema ao qual se ocupa um museu de arte - e aqui, o MASP, à maneira do Metropolitan de Nova Iorque, pretendia criar um acervo de indumentárias. Foram realizados desfiles no qual foram exibidas indumentárias históricas; a produção contemporânea à época representada pela coleção do estilista mais importante em âmbito internacional, Christian Dior, traje elaborado por Salvador Dalí e uma coleção de moda brasileira criada com desenhos de artistas brasileiros, executada nos ateliês $\mathrm{d}$ instituição e comercializada em um grande magazine na cidade de São Paulo imediatamente após o desfile. O MASP, nas suas ousadas iniciativas, inicia e difunde o debate do design, bem como recoloca sob novas perspectivas o papel dos museus junto à sociedade.

A localização do quarto fio, mais visível na historiografia da disciplina, teve como papel rever um possível equívoco acerca das proposições cujo discurso da estética moderna esteve presente. Se defesa das linguagens modernistas parece insinuar-se como a mais adequada ao desenvolvimento do design no Brasil, a prevalência desta se dá mais por outras iniciativas, favorecidas pela conjuntura do País, do que por uma proposição do Museu. O Museu, ao defender a formação de um artista moderno, tem como objetivo uma formação afeita ao uso de materiais e técnicas de sua época e, não na necessária adoção do vocabulário formal modernista.

O quinto é uma tentativa de tramar uma relação do Museu com o empresariado brasileiro, sobretudo paulista, apoiada na reflexão em torno da importância do desenvolvimento da produção nacional com vistas ao processo de industrialização acelerada na qual o País estava imerso, bem como uma tentativa de conscientização por parte do empresariado nacional acerca da importância do design como elemento central para o desenvolvimento da produção nacional.

O sexto fio entrelaçaria várias vontades: as relações entre arte, design e indústria no campo gráfico; a pluralidade de linguagens estéticas que anuncia uma proximidade à reflexão internacional acerca da chamada pós-modernidade e a problemática da adoção de linguagens estéticas pouco afeitas às características culturais do País em virtude da implantação de modelos internacionais para o desenvolvimento e a consolidação do campo no Brasil.

O sétimo, dos mais originais, formaria uma urdidura singular: a constituição de um inventário da cultura nacional como repertório fundamental para o desenvolvimento de uma produção industrial brasileira atenta às reais necessidades do País.

São estes fios que formaram uma trama única, na qual o design afasta-se de abordagens restritivas e vinculadas necessariamente ao processo de industrialização para uma compreensão do design enquanto arte e, arte enquanto consequência do meio - ambos os campos são, portanto, apresentados como respostas às condições técnicas, históricas e estéticas de uma determinada cultura em espaço e tempo específicos, registros e reflexos da multifacetada complexidade, desejos e atitudes de uma sociedade.

Tal convicção encontrará suas raízes na arqueologia - ramo da antropologia - na consideração da materialidade, ora de valor artístico, ora de valor ordinário, enquanto elemento significante para a compreensão do pensamento, dos valores da sociedade à 
qual estes pertencem. Coincidentemente, a visão do Museu para o campo tem sua atualidade, uma vez que é necessário ampliar o debate da disciplina para uma compreensão do campo enquanto resposta às exigências da modernidade. São, portanto, estes os primeiros fios, ainda modestos, de uma trama complexa, da qual este texto pretendeu somente iniciar, cuja clareza se faz necessária

a fim de constituirmos uma ampla historiografia da disciplina no Brasil. 


\section{BIBLIO GRAFIA}

ACAYABA, Marlene Milan. Branco e Preto: uma história de design brasileiro nos anos 50. São Paulo: Instituto Lina Bo e P.M. Bardi, 1994.

AMARAL, Aracy. Arte Construtiva no Brasil. AMARAL, Aracy (org.). São Paulo: Companhia Melhoramentos; São Paulo: DBA Artes Gráficas, 1998. (Coleção Adolpho Leirner) p.29-46.

ARANTES, Otília Beatriz Fiori. Mario Pedrosa: Itinerário Crítico. São Paulo: Editora Pagina Aberta, 1991

ARGAN, Giulio Carlo. Arte Moderna. São Paulo: Companhia das Letras, 1996.

H istória da arte como história da cidade. Martins Fontes 1995.

Progetto e oggeto. Scriti sul design. GAMBA, Cláudio. (org.). Milano, Edizioni Meduza, 2003.

AZEVEDO, Ricardo Marques de. Metrópole: abstração. São Paulo, Perspectiva, 2006

BARDI, Lina Bo. Tempos de grossura: 0 design no impasse. Instituto Lina Bo e P. M. Bardi, 1994

BARDI/ FERRAZ. Lina Bo/ Marcelo Carvalho (coord.). Lina Bo Bardi. São Paulo: Empresa das Artes: Instituto Lina Bo e P.M. Bardi, 1993.

BARDI, Pietro Maria. Mestres, artífices, oficiais e aprendizes no Brasil. São Paulo: Banco Sudameris Brasil, 1981.

Excursão ao território do design. São Paulo: Banco Sudameris Brasil, 1986.

. História do MASP. São Paulo: Instituto Quadrante, 1992.

BASUALDO, Carlos. Vanguarda, cultura popular e indústria cultura no Brasil. BASUALDO, Carlos (org.). São Paulo: Cosa Naify, 2007. 
BAUDOT, François. Moda do Século. São Paulo: Cosac Naify, 2002.

BAYLEY/CONRAN, Stephen/Terence. D iseño - Inteligencia Hecha Materia. Barcelona: Blume, 2008

BRANZI, Andrea. Introduzione al design italiano: una modernità incompleta. Milano: Baldini \& Castoldi, 1999.

. II Design - II design italiano 1964- 2000. Electa, 2008.

BROCKMANN, Josef Müller. Historia de la comunicación visual. Barcelona: Editorial Gustavo Gili, 2005.

BONSIEPE, Gui. Desenho Industrial, Tecnologia e Subdesenvolvimento. Nicolau A. Guida Neto (trad.). São Paulo: FAU.

Teoría y práctica del diseño industrial : elementos para una manualística crítica. Barcelona: Gustavo Gilli, 1978.

Paesi in via di sviluppo: la coscienza del disegn e la condizione periferica. In: CASTELNUOVO, Enrico (org.) Storia del Disegno Industriale - 1919-1990 II domínio del design. Milano: Electa, 1991

BONSIEPE/FERNÁNDEZ, Gui/Silvia. Historia del diseño em América Latina y el Caribe. São Paulo: Editora Blücher, 2008.

BOSONI, Giampiero (org.). II Modo Italiano - Italian Design and Avant-garde in the 20th C entury. Milano: Skira Editore S.p.A., 2006 CALVERA, Anna (org.). De lo bello de las cosas. Barcelona: Editorial Gustavo Gili, 2007.

CARA, Milene. Do desenho industrial ao design: uma bibliografia crítica para a disciplina. São Paulo: Blucher, 2010

CASTELNUOVO, Enrico. Storia del Disegno Industriale - 19191990 Il domínio del design. CASTELNUOVO, Enrico (org.) Milano: Electa, 1991

CASTELNUOVO/GLUBER/MATTEONI.Enrico/Jacques/Dario. L'oggetto misterioso. In: CATELNUOVo, Enrico (org.) Storia del
Disegno Industriale - 1919 - 1990 II dominio del design. Milano: Electa, 1991

CARDOSO, Rafael. 0 design brasileiro antes do design: aspectos da história gráfica, 1870-1960. CARDOSO, Rafael (org.) São Paulo: Cosac Naify, 2005.

U ma introdução à história do design. São Paulo: Edgard Blücher, 2004 Naify, 2012

CORBUSIER, Le. A Arte Decorativa. São Paulo: Martins Fontes, 1996.

DORFLES, Gillo. Introduzione al disegno industriale. Bologna, 1963. Simbolo, comunicacion y consumo. VIALE, Maria Ros (trad.). Barcelona: Lumen, 1967

Artificio e N atura. Torino, 1968

Devenire della critica. Torino: Einaudi, 1982.

0 design industrial e a sua estética. Lisboa, 1991

ESCOLA SUPERIOR DE DESENHO INDUSTRIAL. ESDI - Conseqüências de uma idéia. Catálogo comemorativo dos 30 anos da Escola Superior de Desenho Industrial ESDI. Rio de Janeiro, 1993.

FAUSTO, Boris. História Concisa do Brasil. São Paulo: Editora da Universidade de São Paulo, 2006

História do Brasil. São Paulo: Editora da Universidade de São Paulo, 2010

FUSCO, Renato de. Storia del Design. Bari, 1985.

GIEDION, Siegfried. Mechanization takes command:a contribution to anonimous history. New York: Oxford University Press, 1948

JULIER, Guy. La Cultura del D iseño. Barcelona: Editorial Gustavo Gili, 2010. 
KATINSKY, Júlio Roberto. D esenho Industrial. In ZANINI, Walter (org.) História geral da arte no Brasil. São Paulo: Instituto Moreira Salles, $2^{\circ} \mathrm{V}$., 1983.

LEITE, João de Souza. A herança do olhar: 0 design de Aloísio Magalhães. Rio de Janeiro: Artviva, 2003.

De costas para o Brasil - o ensino de um design internacionalista. In: MELO, Chico Homem de (org.). 0 design gráfico brasileiro: anos 60. São Paulo: Cosac Naiify, 2006

MELO, Chico Homem de. 0 design gráfico brasileiro: anos 60 MELO, Chico Homem de (org.). São Paulo: Cosac Naify, 2006.

MELO/COIMBRA, Chico Homem de/Elaine Ramos (orgs.). Linha do tempo do design gráfico no Brasil. São Paulo: Cosac Naify, 2011.

MONTANER, Josep Maria. La modernidad superada - Arquitectura, arte y pensamiento del siglo XX. Barcelona: Gustavo Gilli, 1997. MORAES, Dijon De. Análise do design brasileiro: entre mimese e mestiçagem. São Paulo: Edgard Blücher, 2006.

NESBITT, Kate (org.). U ma nova agenda para a arquitetura: teórica (1965-1990). São Paulo: Cosac Naify, 2006.

NETO, Eduardo Barroso. Estratégia de design para países perifériCos. Brasília: Ed. CNPq, 1981, p.17.

NIEMEYER, Lucy. Design no Brasil: origens e instalação. Rio de Janeiro, Ed. 2AB, 1997.

PAPANEK, Victor J. Diseñar para el mundo real : ecología humana y cambio social. ALVARO, Luis Cortés de (trad.). Madrid: H. Blume Ediciones, 1977.

PEDrosA, Mario. Arte A mbiental, Arte Pós-Moderna, Hélio Oit icica. In: Dos murais de Portinari aos espaços de Brasília. AMARAL, Aracy (org.). São Paulo, Editora Perspectiva, 1981.

PEVSNER, Nikolaus. Pioneiros do desenho moderno: de W illiam Morris aW alter Gropius. São Paulo: Martins Fontes, 1980
PEVSNER, Nikolaus. Estudios sobre arte, arquitectura y diseño del manierismo al romanticismo, era victoriana y siglo XX. Barcelona : Gustavo Gili, 1983

REDIG, Joaquim. Um encontro histórico. D esign \& Interiores (10) 1988. p.108-110.

RIBEIRO, Darcy. 0 povo brasileiro: a formação e o sentido do Brasil. São Paulo: Companhia das Letras, 1995, p.202.

RICARD, André. Conversando com estudiantes de diseño. Barcelona: Editorial Gustavo Gili, 2008.

ROSSETTI, Eduardo Pierrotti. Tensão moderno/popular em Lina Bo Bardi: nexos de arquitetura. Disponível em: http://www.vitruvius.com.br/arquitextos.

RUBINO/GRINOVER, Silvana/Marina (orgs.). Lina por escrito.Textos escolhidos de Lina Bo Bardi. São Paulo: Cosac Naify, 2009.

SANTOS, Maria Cecília Loschiavo dos. Móvel moderno no Brasil. São Paulo: Studio Nobel: FAPESP,1995.

SEGAWA/CREMA/GAVA. Hugo/Adriana/Maristela. Revistas de arquitetura, urbanismo, paisagismo e design: a divergência de perspectivas. Ci. Inf., Brasília, v.32, n.3, p. 120-127, set./dez. 2003.

STOLARSKI, André. Alexandre Wollner e a formação do design moderno no Brasil: depoimentos sobre o design visual brasileiro São Paulo: Cosac Naify, 2005.

VERSIANI/SUZIGAN. Flávio/Wilson. 0 processo brasileiro de industrialização: uma visão geral. (Texto preparado para a seção relativa à industrialização da América Latina no X Congresso Internacional de História Econômica, Louvain, agosto de 1990).

WODD/FRASCINA/HARRIS/HARRISON.Paul/Francis/Jonathan/ Charles. Modernismo em D isputa - A arte desde os anos quarenta. São Paulo: Cosac Naify, 1998. 
Anexos 


\section{EXPOSIÇÃO DA CADEIRA}

TíTULO DA EXPOSIÇÃO

DATA E LOCAL

Em I 4 de Setembro de 1949

no Museu de Arte de São Paulo (MASP)

REFERÊNCIA ARQUIVO HISTÓRICO DO MASP

caixa $05 /$ pasta 57

DiRETOR DA InSTITUIĊ̃̃o NO PERÍOdO

Pietro Maria Bardi

TEMA DA EXPOSIIÇ̃̃o (PALAVRA-CHAVE)

cadeiras, objeto de uso cotidiano

CURADORES OU RESPONSÁVEIS PELO

PROJETO DA EXPOSICÃO

A exposição é uma iniciativa de

Lina Bo Bardi, com a colaboração do

arquiteto Giancarlo Palanti, Dr. G.

Giacomini e o pintor Eurico Camerini.

OBjeTIVO DO EVENTO

A exposição é a primeira de uma série

dedicada às artes industriais, na qual

o objeto é abordado sob os pontos de

vista estético, técnico e histórico, por meio

da apresentação de painéis e exemplares

de cadeiras cronologicamente organizados,

como forma de estimular a percepção e o

juízo crítico acerca da importância

da escolha dos objetos de uso cotidiano.
Material eXPositivo

Cadeiras e quadros demonstrativos com

centenas de fotografias e reproduções de

catálogos dispostos em ordem cronológica.

FORTUNA CRITICA

Exposição da cadeira.

Diário de São Paulo, 26 de Março de 1948.

Exposição cronológica do desenvolvimento das

formas da cadeira no Museu de Arte.

Folha da Noite, 16 de Setembro de 1948.

Verdadeira síntese da história da cadeira.

A primeira mostra de uma série dedicada às artes

industriais. Diário da Noite, 18 de Setembro

de 1948.

Exposição da cadeira. Diário de São Paulo,

19 de Setembro de 1948.

No Museu de Arte. Diário de São Paulo,

$I^{\circ}$ de Agosto de 1948.

Exposição da Cadeira. O Estado de São Paulo,

14 de Setembro de 1948.

DOCUMENTOS PRESENTES NO ACERVO HISTÓRICO

Textos com os objetivos da exposição.

Carta à agência nacional redigida por

G. Borchardt (assistente). 
DATA E LOCAL

$2^{\circ}$ semestre de 1949

no Museu de Arte de São Paulo (MASP)

REFERÊNCIA ARQUIVO HISTÓRICO DO MASP

Caixa I /Pasta 7

DiRetor dA Institulção No PERÍODO

Pietro Maria Bardi

TEMA DA EXPOSIÇÃo (PALAVRA-CHAVE) artes gráficas

CuRADORES OU RESPONSÁVEIS PELO

PROJETO DA EXPOSIÇÃO

Pietro Maria Bardi e Lina Bo Bard

contaram com a colaboração do

Departamento de Pesquisas em Artes

Gráficas, a Escola de Artes Gráficas do

SENAI e de biblió-filos, entre eles,

o Sr. Ernani Seabra.

OBjetivo do EVEnTO

Por meio da exibição de documentos

antigos e raros somados a painéis didáticos,

a exposição teve como objetivo apresentar

a evolução da técnica e dos processos

empregados na execução das artes gráficas,

assim como possibilitar a compreensão

dos trabalhos que são realizados na

confecção de livros, impressos, jornais

outros serviços gráficos. Além da exposição, foram propostas as exibições de filmes sobre artes gráficas, palestras, conferências, aulas no Museu e visitas às indústrias gráficas.

$\mathrm{Na}$ mesma ocasião foi lançada a revista Brasil Gráfica, primeira revista sobre artes gráficas

da Editora Brasil Gráfico Ltda. Um seminário de biblioteconomia promovido pelo Instituto de Administração da Universidade de São

Paulo a ser realizado no auditório do Museu é citado, mas não há informações concretas sobre o acontecimento de fato do evento.

MATERIAL EXPositivo

Documentos antigos, como fragmentos

de papiros, pergaminhos, manuscritos e

pranchas didáticas com sequências históricas

da evolução da técnica e dos processos

empregados em artes graficas.

FORTUNA CRÍTICA

Uma "secção do livro" no Museu de Arte. Diário da Noite, 03 de junho de 1949

"Secção do Livro" no Museu de Arte. Diário de São Paulo, 03 de junho de 1949.

Brevemente, no Museu de Arte - Exposição das Artes Gráficas no Museu de Arte. Diário de São Paulo. 17 de junho de 1949. 
de 1949.

Exposição Didática de Artes Gráficas. Diário de São Paulo, 17 de julho de 1949.

DOCUMENTOS PRESENTES NO ACERVO HISTÓRICO Projeto de exposição didática de artes gráficas de 1949

Resumo das principais atividades que se

realizam em artes gráficas organizadas pelo

Departamento de Pesquisas em Artes Gráficas (DPAG)

Resumo da Exposição Didática de Artes

Gráficas no Museu de Arte de São Paulo pelo

DPAG

Catálogo da Exposição Didática de Artes

Gráficas

\section{Exposição de Arte Popular Pernambucana}

Título dA EXPOSIÇão

DATA E LOCAL

inaugurada em 26 de Janeiro de 1949

no Museu de Arte de São Paulo (MASP).

REFERÊNCIA ARQUIVO HISTÓRICO DO MASP

Caixa I /Pasta I

DIRETOR DA INSTITUIÇÃO NO PERÍODO

Pietro Maria Bardi

Tema da eXposição (palaVra-chaVe)

Arte popular

CURADORES OU RESPONSÁVEIS PELO

PROJETO DA

Pietro Maria Bardi, Lina Bo Bardi e

Augusto Rodrigues.

OBJETIVO DO EVENTO

A exposição tem como objetivo inicial

apresentar a importância da iniciativa

puseu am criar uma seça dedica

à arte popular brasileira como

forma de consolidar um acervo

fundamental para estudos.
Material eXPositivo

“(...) Peças de cerâmica, "ex-votos" e

mamulengos fazem parte da expressiva mostra que foi distribuída artisticamente pela sra. Lina

Bo Bardi, apresentando, pela primeira vez

a São Paulo, toda uma documentação da

vida rural, dos costumes e das coisas de

Pernambuco. Pequeninas figuras de cerâmica,

pertencentes às coleções de Augusto

Rodrigues e do diretor do Museu, representam

entre outras, as cenas de barbeiro do interior,

ladrões de bode, a luta do negro com a onça;

enquanto os "ex-votos", todos de madeira

simbolizam a fé nordestina plasmada pela

influencia acentuada do africano, que enriquece

essas peças de valor plástico. Os mamulengos,

também de madeira, são os fantoches dos

teatrinhos populares das cidades e do sertão

FORTUNA CRÍTICA

Coleção de cerâmica nordestina em exposição no Museu de Arte. Bonecos de barro de Vitalino, o artista do agreste do Caruaru - Interesse

sociológico dos trabalhos. Diário de São Paulo, 19 de Dezembro de 1948. 
No Museu de Arte - Mostra de cerâmica popular nordestina. Congratulações da Comissão Nacional do Folclore. Diário da Noite, 21 de Janeiro de 1949.

No Museu de Arte - Inaugura-se hoje exposição de arte popular nordestina. Sob patrocínio do órgão nacional da UNESCO. Diário de São Paulo, 26 de Janeiro de 1949. PAIVA, Fátima. Artes plásticas. Cerâmica de Pernambuco no Museu de Arte. Época, 26 de laneiro de 1949.

A vida das populações nordestinas retratada numa admirável exposição de cerâmica. Folha da Noite, 3 | de Janeiro de 1949.

\section{$I^{\circ}$ Salão de Propaganda}

Titulo da eXPosição

DATA E LOCAL

Aberta em 4 de dezembro de 1950 (dia internacional da propaganda) no Museu de Arte de São Paulo (MASP)

REFERÊNCIA ARQUIVO HISTÓRICO DO MASP

Caixa 06/ Pasta 32

Diretor da institurcão no período

Pietro Maria Bardi

TEMA DA EXPOSIÇÃO (PALAVRA-CHAVE)

Propagand

Curadores ou responsáveis pelo

ROJETO DA EXPOSICC̃̃o

Pietro Maria Bardi, Lina Bo Bardi, Geraldo Wilda e Associação Paulista de Propaganda.

OBJETIVO DO EVENTO

A mostra teve como objetivo a tentativa de apresentar o desenvolvimento da

propaganda em outros países e no Brasil na primeira metade do século $X X$. E também, as propostas de debate acerca do papel do publicitário no exercício da criação e da compreensão da publicidade como meio de arte visual.
Material expositivo

$\mathrm{Na}$ exposição existiram três seções: uma

histórico-didática - a retrospectiva da história

e do desenvolvimento da propaganda e outras duas, dedicadas à representação das agências e à representação dos artistas. $\mathrm{Na}$ representação dos artistas foram exibidos: uma rara coleção de cartazes de Toulouse-Lautrec e litografias de Cheret cedidas pela Galeria Knoedler,

de Nova York; originais de I85I, realizados por ocasião da Exposição Internacional de Londres, raros catálogos de indústrias; cartazes de teatros do século passado e anúncios realizados na Europa na primeira metade do século XX.A mostra foi ainda acompanhada por uma sequência de palestras e filmes acerca do tema.

FORTUNA CRÍTICA

Salão Nacional de Propaganda. Folha da Manhã, 20 de outubro de 1950.

I Salão Nacional de Propaganda.

Diário de São Paulo, 15 de outubro 1950

I Salão de Propaganda

Folha da Noite, 3 I deoutubro de 1950 
O I Salão de Propaganda. "Esperamos que se reproduza por vários anos e que não seja tentativa isolada". "Vai ele mostrar várias coisas e principalmente que existe uma equipe de inteligência atrás de cada anúncio" - diz o Sr. Eliezer Burlá.

Diário de São Paulo, 29 de outubro de 1950

Em fase já de realização pratica a ideia do I Salão de Propaganda - reunião ontem no Museu de Arte presidida pelo prof. P. M. Bardi. Diário de São Paulo, 3 I de outubro de 1950.

Salão Nacional de Propaganda.

Folha da Manhã, $\left.\right|^{\circ}$ de novembro de 1950 "Mais uma vez demonstra o Museu de Arte a sua grande capacidade idealizadora". "A abertura do I Salão Nacional de Propaganda deve ser aguardada como um acontecimento" - afirma o Sr. Sousa Ramos, presidente da PANAM. Diário de São Paulo, 4 de novembro de 1950

Contribuirá para criação de nova mentalidade sobre a arte publicitária. "De forma alguma poderia a Gessy ficar alheia ao I Salão Nacional de Propaganda" - afirma o S Alexandre Jorás Neto. Diário de São Paulo, 10 de novembro de 1950

Aspectos pitorescos da propaganda.

Conferências da Semana. Folha da Manhã, 7 de janeiro de 1951.

Pleno êxito do I Salão Nacional de Propaganda. Encerrará hoje a série de palestras de Godoy Prado. Diário de São Paulo, 5 de janeiro de 1951

Conferência de Godoy Prado no Museu de Arte. $O$ tempo, 4 de janeiro de 195 I
Evolução da Propaganda no Brasil. Nascimento e desenvolvimento da arte publicitária no país. Conferência de encerramento do I Salão Nacional de Propaganda. Diário da Noite, 4 de janeiro de $|95|$.

Função Educacional da Propaganda. Folha da Manhã, Conferências da Semana, 24 de dezembro de 1950

Função Educacional da Propaganda. Diário de São Paulo, 22 de dezembro de 1950.

São Paulo de 1868 através dos anúncios da época. Hoje, a palestra do Sr. Origenes Lessa, no Museu de Arte. Diário de São Paulo, I5 de dezembro de 1950.

Palestra no Museu de Arte. Diário da Noite, 15 de dezembro de 1950.

I Salão Nacional de Propaganda. Diário de São Paulo, 5 de dezembro de 1950 Propaganda da Propaganda. Diário de São Paulo. 5 de dezembro de 1950

$I^{a}$ Exposição de Propaganda. Da Silva, Quirino. Diário da Noite, 4 de dezembro de 1950. A propaganda já faz parte da nossa vida. Não há um só momento que não agimos sob influência - um "salão" diferente. Diário de São Paulo, domingo, 3 de dezembro de 1950.

Lautrec e Cheret para o Salão de Propaganda. Diário de São Paulo, 26 de novembro de 1950.

Propaganda e Arte Visual. Diário de São Paulo, 19 de novembro de 1950.

\section{Cinquenta expositores no I Salão de}

Propaganda. Encerradas as inscrições para a mostra a ser realizada pelo Museu de Arte. 16 de novembro de 1950

\section{VITRINE DAS FORMAS}

TítULO DA EXPOSIÇÃo

DATA E LOCAL

Em 1950, no Museu de Arte de São Paulo (MASP)

REFERÊNCIA ARQUIVO HISTÓRICO DO MASP Caixa 02/ Pasta 09

DIRETOR DA INSTITUIÇÃO NO PERÍODO

Pietro Maria Bardi

TEMA DA EXPosição (PalaVra-chaVE) Exposição didática

CURADORES OU RESPONSÁVEIS PELO PROIETO DA EXPOSICÃO

Pietro Maria Bardi, Lina Bo Bardi,

Objetivo do eVEnTo "Esta exposição tem um sentido museológico diferente: não pretende ser apenas uma apresentação de objetos "antigos", mas uma reunião m coniunto de formas varia em conjunto de formas variadas, criadas por civilizações diferentes ou originadas simplesmente por circunstâncias casuais, mostrando a variabilidade da fantasia humana na criação e modificação dos materiais, dentro de um impulso renovador incessante.

A maioria das pessoas costuma encarar a forma com certa indolência visual, isto é, com certa falta de discriminação ou espírito de comparação, quase sempre adquirindo um copo ou um aparelho de rádio, uma máquina de costura ou um vaso, sem consciência da importância e responsabilidade que a entrada de uma nova forma representa para a casa. (Verdade é que na maioria das vezes a própria arquitetura da casa obedece à mesma indiscriminação (sic) de valores e de gosto).

Esta exposição visa, portanto, despertar atenção sobre: proporção, racionalidade, inteligência, gosto, arte, historicidade de toda e qualquer forma com a qual se entra em contato. De dois em dois meses serão organizadas exposições periódicas dentro desse critério orgânico e didático.

Todos os objetos desta vitrine foram gentilmente cedidos pela Sra. Lina Bardi.(...)"

Material eXPositivo

Diversos objetos de períodos, técnicas e materiais distintos.

DOCUMENTOS PRESENTES NO ACERVO HISTÓRICO

TextoVITRINE DAS ForMAS sem autoria identificada.

1. Trecho extraído de texto intitulado Vitrine da Formas sem identificação de autoria, porém provavelmente de P. M. Bardi ou Lina Bo Bardi localizado no Arquivo Histórico do Museu. 


\section{EXPOSIÇÃo Le CORBUSIER}

Título dA EXPOSIÇÃo

DATA E LOCAL

Em 1950, no Museu de Arte de São Paulo

(MASP)

REFERÊNCIA ARQUIVO HISTÓRICO DO MASP

Caixa 5.1/ Pasta 30

DIRETOR DA INSTITUIÇÃO NO PERÍODO

Pietro Maria Bardi

TEMA DA EXPOSIÇÃO (PALAVRA-CHAVE)

Le Corbusier, modernismo, arquitetura moderna

\section{Curadores ou responsávels pelo}

PROIETO DA EXPOSIC̃̃O

Pietro Maria Bardi, Lina Bo Bardi,

OBjetivo do EVENTO

"Para a inauguração da sala de exposições

no Museu de Arte, escolhemos a obra

completa de Le Corbusier. Primeiramente

porque o Museu vem se engajando em

tentativas e estímulos energéticos e

significativos em favor da arquitetura

contemporânea. Em segundo lugar, porque

Le Corbusier é considerado o responsável, em grande parte, pela renovação

construtiva de nosso tempo. E, finalmente

porque foi ele que tão adequadamente

influenciou o crescimento da arquitetura

nacional no Brasil."

MATERIAL EXPOSITIVO

Fotos, desenhos, textos das obras de Le

Corbusier e suas pinturas.

DOCUMENTOS PRESENTES NO ACERVO HISTÓRICO

O texto Projeto DA EXPOSIÇÃo sem autoria

identificada.

Trecho traduzido pela autora e extraído de documento localizado no Arquivo Histórico do Museu , porém sem autoria definida. 


\section{EXPOSIÇ̃̃o MAX BILL}

Título DA EXPOSIÇ̃̃o

DATA E LOCAL

Em 01 de março de 195I, às 15 horas no

Museu de Arte de São Paulo (MASP). Na

mesma data são inaugurados os cursos do

Instituto de Arte Contemporânea (IAC).

REFERÊNCIA ARQUIVO HISTÓRICO DO MASP

Caixa 03/ Pasta I3 e Pasta I4.

Diretor da Instituição no períOdO

Pietro Maria Bardi

Tema da exposição (palayra-chave) Max Bill

CURADORES OU RESPONSÁVEIS PELO

ProjetO DA EXPOSIC̃̃o

Pietro Maria Bardi, Lina Bo Bardi.

OBJETIVO DO EVENTO

A exposição da obra completa de Max

Bill, arquite

de fundamental impor

senvolvimento da arte abstracionis

senvolvimento da arte abstracionis
ta, teve como objetivo, assim como outras exposições realizadas anteriormente pelo Museu, apresentar manifestações de arte contemporânea como tentativa de consolidação de uma visão histórica explicativa da própria época
Material eXPositivo

47 esculturas e pinturas, 27 pranchas com plantas, fotos e 14 impressos.

FORTUNA CRÍTICA

No Museu de Arte a obra completa de Max Bill. Diário de S. Paulo, domingo, 21 de agosto de 1949

A obra completa de Max Bill no Museu de Arte. Diário da Noite, 22 de agosto de 1949.

Max Bill no Museu de Arte. Diário da Noite, 14 de janeiro de 1950.

Livro e exposição sobre Max Bill. Diário de São Paulo, 5 de abril de 1950.

Exposição sobre Max Bill. Diário da Noite, 5 de abril de 1950. 


\section{EXPosição CarTAZES Suíços}

Título DA EXPOSIÇÃO

DATA E LOCAL

Inaugurada em 08 de abril de 195I, às 17

horas no Museu de Arte de São Paulo

(MASP).

REFERÊNCIA ARQUIVO HISTÓRICO DO MASP

Caixa 08/ Pasta 08

Diretor da instituicão no período

Pietro Maria Bardi

TeMA DA EXPOSIÇ̃̃o (palaVRa-chaVe)

Cartazes Suíços

Curadores ou responsávels pelo

RROJETO DA EXPOSIÇÃO

M. Bardi, Lina Bo Bardi,

Consulado da Suíça em São Paulo,

Fundação PRO HELVETIA.

OBJETIVO DO EVENTO A exposição dedicada
à apresentação da produção de cartazes

suíços ocorre em colaboração com o Con-

suíços ocorre em colaboração com o Con-
sulado da Suíça. Esta mostra já havia per-

sulado da Suíça. Esta mostra já havia per-
corrido o Uruguai, depois de já ter passado

por países da Europa e América.

A produção de cartazes suíça é vista àquele período como uma das mais expressivas

afirmações da cultura moderna e, demonstra

a responsabilidade da publicidade sobre a

influência do gosto do público. Dentro dessa

perspectiva, é de interesse do Museu a ex-

posição, uma vez que ela reafirma o interesse

da instituição em colaborar para que as pesqui-

sas em arte contemporânea atinjam veículos

de ampla divulgação.

MATERIAL EXPOSITIVO cartazes.

FORTUNA CRÍTICA Inaugura-se no Museu de Arte a exposição de cartazes suiçcos. Diário de São Paulo, 9 de janeiro de 1951 


\section{Primeiro Desfile de Costumes Antigos e Modernos}

DATA E LOCAL

Ocorreu em 27 de abril no Museu de Arte de São Paulo (MASP) e posteriormente, no Copacabana Palace, no Rio de Janeiro

REFERÊNCIA ARQUIVO HISTÓRICO DO MASP Caixa 04/ Pasta 22

DiRETOR DA INSTITUIÇÃo NO PERÍOdO

Pietro Maria Bardi

TeMa da eXPosição (palaVRA-ChaVe)

Desfile de roupas do estilista francês

Christian Dior e costumes antigos (moda)

Curadores ou responsáveIs pelO

PROJETO DA EXPOSIÇÃO

Pietro Maria Bardi, Lina Bo Bardi, Sr. Paulo Franco (diretor da Casa Vogue). O dinheiro arrecadado com a venda de ingressos fol

destinado à Campanha da Criança pro

Monumento a Monteiro Lobato.

\section{OBjeTIVO DO EVENTO}

À maneira do museu Metropolitan de

Nova York, o MASP pretendia na ocasião,

demonstrar a importância da moda para um museu de arte, ao tratar o campo como um

verdadeiro patrimônio cultural que reconstitu

o desenvolvimento da arte e dos costumes de um povo. Outra iniciativa ligada ao evento era a constituição de uma secção de costumes no Museu, para a qual se solicitava a doação dos trajes antigos.

MATERIAL EXPOSITIVO

desfile de trajes de Christian Dior e trajes de época.

FORTUNA CRÍTICA

Parada de modas deste e de outros tempos.

Esplendor da costura francesa na "passarelle" instalada no Museu de Arte.

Diário da manhã, I de abril de 195।.

Na fantasia de Salvador Dalí

a moda do ano 2045. Diário de São Paulo, 28 de março de 1951.

Modelo do século XVIII no

desfile do Museu de Arte. Diário de São Paulo, 29 de março de 1951. 


\section{$j^{\circ}$ Desfile de Moda Brasileira}

nauguração dia 6 de novembro de 1952, às

17 horas no Museu de Arte de São Paulo

(MASP).

REFERENCIA ARQUINO HISTORICO DO MASP

Caixa 03/ Pasta 15

Iretor da instituicão no período

Pietro Maria Bardi

Tema da eXPosição (palavra-chave)

Moda Brasileira

Curadores ou responsávels pelo

ROJETO DA EXPOSIÇÃO

Pietro Maria Bardi, Lina Bo Bardi, Clar

Hartoch (orientadora do curso de

tecelagem do museu), artistas convidados

(Burle Marx, Lilly Correia de Araújo, Caribé,

Roberto Sambonet).

OBJETIVO dO EVENTO

MASP, ao apresentar o primeiro

desfile de moda brasileira, com trajes

confeccionados dentro dos ateliers e

escolas do Museu por um grupo de artistas,

industriais e artesãos convidados, teve

como objetivo projetar, tanto em âmbito

nacional como internacional, a criação de

uma moda brasileira

MATERIAL EXPOSITIVO

Os trajes confeccionados no Museu

FORTUNA CRITICA

Modelos típicos no primeiro desfile de moda

brasileira. Iniciativa vitoriosa do Museu de Arte

e do Mappin - Democratização da alta costura

em beneficio da elegância. Diário da Noite, 7 de

novembro de 1952.

Desfile de Moda Brasileira. $\bigcirc$ Jornal.

Rio de Janeiro, 08 de novembro de 1952

O $1{ }^{\circ}$ Desfile de Moda Brasileira. $O$ Jornal. Rio de aneiro, 07 de novembro de 1952.

Traçou rumos novos para a elegância feminina. $O$ desfile de modelos de inspiração brasileira.

A Sociedade paulista compareceu em

elevado número para aplaudir a realização

acontecimento inédito em nossa terra - variedade

de modelos apresentados - impressões de damas

da nossa elite. $2^{\mathrm{a}}$ feira, 10 de novembro de 1952. Diário da Noite.

Lançamento da Moda Brasileira. Elegante tarde de quinta-feira coroou-se de êxito - desfilaram

"Abacate”, “Cunhambebe”, “'Jangada”, “Macumba"

e outros modelos. Folha da Manhã, 9 de

novembro de 1952 


\section{EXPOSIÇÃO BADIA VILATÓ}

Título da EXPOSIÇÃo

DATA E LOCAL

Inaugurada em 9 de junho de 1953, às I8h

no Museu de Arte de São Paulo (MASP)

ReFERÊnCIA AROUIVO HISTÓRICO dO MASP

Caixa I /Pasta 5

DiRETOR DA InSTITUIÇÃO NO PERÍODO

Pietro Maria Bardi

TEMA da EXPosição (palaVra-chaVe)

Badia Vilató

CurAdores OU RESPONSÁVEIS PELO

PROJETO DA EXPOSIÇC̃O

Pietro Maria Bardi, Lina Bo Bardi

OBJETIVO DO EVENTO

A exposição de cartazes do catalão

Eduardo Badia Vilató no Museu tinha como

objetivo propor uma visão da publicidade

enquanto expressão artística.

MATERIAL EXPOSITIVO

Uma série de cartazes pintados

por Badiá Vitaló

FORTUNA CRÍTICA

La publicidad es una de las formas vivas del arte

de nuestro tempo. Badia Vitaló, el gran afichista

catalán, cree que ella puede devolver a la pintura

catalan, cree que ella puede devolver a la pital. El Comercio, Lima, Sábado,

25 de outubro de 1952. 


\section{EXPOSIÇÃo HISTÓRIA DO CALÇADO}

Título da EXPOSIÇÃo

Data elocal

Realizada no Museu de Arte de São Paulo

(MASP), porém não foram localizadas

informações que confirmem a data correta

do evento.A única informação de registro

temporal é o ano 1961.

REFERÊNCIA ARQUIVO HISTÓRICO DO MASP

Caixa 01/ Pasta 7

DIRETOR DA INSTITUIÇÃO NO PERÍODO

Pietro Maria Bardi

TEMA DA EXPOSIČ̃̃o (PALAVRA-CHAVE)

História do Calçado

CurAdores oU RESPONSÁVEIS

Pietro Maria Bardi, Lina Bo Bardi,

Objetivo do EVENTO

Documentos ou artigos dedicados à exposição são escassos no acervo histórico do Museu. Há

um único documento localizado com a relação dos calçados antigos a serem apresentados na exposição, organizados por meio de categorias históricas. Esta classificação nos leva a crer

que se tratava de uma exposição de caráter

quétítico-histórica semelhante aos eventos

Vitrine das Formas e o Desfile de Costumes Antigos e Modernos.

Material eXPositivo

Sapatos de diversos locais e épocas

FORTUNA CRÍTICA não há 
DESENHO INDUSTRIAL SUECO

Título dA EXPOSIÇÃo

DATA E LOCAL

Realizada primeiramente no Rio de Janeiro e, em novembro de 1965, no Museu de

Arte de São Paulo (MASP).

REFERÊNCIA ARQUIVO HISTÓRICO DO MASP

Caixa I /Pasta 2

DiRetor da instituicão no período

Pietro Maria Bardi

Tema da EXPOSIIÇ̃̃o (PALAVRA-ChAVE)

Desenho Industrial Sueco

Curadores ou responsávels pelo

PROJETO DA EXPOSIC̣ÃO

Pietro Maria Bardi, Lina Bo Bardi,

Embaixada Sueca do Rio de Janeiro,

Instituto Sueco.

OBJETIVO DO EVENTO

A pedido do Cônsul Geral Sueco no Brasil,

Erik Svedelius, a Pietro Maria Bardi, é

solicitado espaço no Museu para receber

a mostra dedicada às homenagens do $4^{\circ}$

Centenário da cidade do Rio de Janeiro,

exposta na cidade carioca em outubro do

mesmo ano, durante a Semana Sueca.

MATERIAL EXPOSITIVO

10 vitrines com artefatos industriais.

DOCUMENTOS

Carta do Cônsul Geral Sueco no Brasil, Erik

Svedelius, a Pietro Maria Bardi 


\section{Exposição Coletiva Olivetti}

Título da EXPOSIÇÃO

DATA E LOCAL

De 14 a 30 de outubro de 1966 no Museu

de Arte de São Paulo (MASP)

REFERÊNCIA ARQUIVO HISTÓRICO DO MASP

Caixa I /Pasta 10

DIRETOR DA INSTITUIÇÃo NO PERÍODO

Pietro Maria Bardi

TEMA dA EXPosição (PALAVRA-ChaVE)

Olivetti, arte, tecnologia

CuRADORES OU RESPONSÁVEIS PELO

PROJETO DA

Pietro Maria Bardi, Lina Bo Bardi

Olivetti Industrial S.A.

OBJETIVO DO EVENTO

A Olivetti encomendara a vários artistas

A

realizadas à fubrica da empresa em

Guarulhos. E para a exposição dessa

iniciativa, solicitou ao Museu o apoio por

meio da seção do espaço, bem como loca

para a organização de um debate sobre

o tema das artes plásticas na civilização

tecnológica moderna - "Civiltà delle

macchine". A proposta tem como objetivo suscitar uma análise aprofundada das relações entre arte e tecnologia, de grande atualidade ao País que ingressava num crescente processo de industrialização.

MATERIAL EXPOSITIVO

Obras inspiradas na visita feita por artistas à fábrica Olivetti em Guarulhos.

DOCUMENTOS

Carta de Guido Santi, redigida em I4 de junho de 1966, a Pietro Maria Bardi. 


\section{A Mão do Povo Brasileiro}

Título da EXPOSIÇÃO

DATA E LOCAL

No ano de 1969 no Museu de Arte de São Paulo (MASP)

REFERÊNCIA ARQUIVO HISTÓRICO DO MASP Caixa I /Pastas 4 e 5

DIRETOR DA INSTITUIÇÃo NO PERÍODO

Pietro Maria Bardi

TEMA DA EXPosição (palaVRA-CHAVE)

Arte Popular Brasileira

CurAdores ou responsávels pelO

PROJETO DA EXPOSICYÃO

Pietro Maria Bardi, Lina Bo Bardi.

OBjeTIVO dO EVENTO

A primeira grande exposição do Museu de Arte de São Paulo em sua nova sede

teve como objetivo

tornar-se recurso fundamental para a

sistematização das produções populares

brasileiras. A exposição reuniu inúmeros

objetos artesanais de forma a converter-se

num grande inventário da cultura popular

do País dos últimos 250 anos.
Uma notável documentação para a

constituição, em novas bases, de uma história da arte do povo do Brasil.

Material eXPositivo

Objetos produzidos artesanalmente pelo povo brasileiro. 


\section{DESENHO INDUSTRIAL DA ESCANDINÁVIA}

TÍTULO DA EXPOSIÇÃO

DATA E LOCAL

De 04 a 2 I de março de 197I, no Museu

de Arte de São Paulo (MASP)

REFERÊNCIA ARQUIVO HISTÓRICO DO MASP

Caixa $2 /$ Pasta 7

DiRetor da Institulção No PERíodo

Pietro Maria Bardi

Tema da eXPosição (Palavra-CHAVE)

Desenho Industrial da Escandinávia

CURADORES OU RESPONSÁVEIS PELO

PROJETO DA EXPOSIÇÃO

Jan Dranger e Johan Huldt (arquitetos

suecos); Associação Brasileira de

Desenho Industrial (ABDI); Karl-heinz

Bergmiller, Ricardo Ohtake, Dalton de

Luca; embaixadores da Finlândia, Noruega,

Dinamarca e Suécia e Cômite Executivo

Escandinavo.

OBJETIVO DO EVENTO

A exposição, anteriormente exibida na II

Bienal de Desenho Industrial no Museu de

Arte Moderna no Rio de Janeiro em 1970

vem a São Paulo, maior centro industrial

brasileiro, por escolha da ESDI.A mostra

de desenho industrial foi organizada com

colaboração de instituições representantes dos países Escandinavos como forma de demonstrar às indústrias paulistas, um modelo de alta qualidade da produção industrial, similar ao que já se encontrava nos tradicionais campos do design escandinavo.

MATERIAL EXPOSITIVO

artefatos industriais de variadas naturezas: equipamentos, ferramentas, mobiliário, utensílios, objetos, entre outros.

FORTUNA CRÍTICA

Desenho industrial. O Estado de São Paulo, 04 de março de 1971.

FERRAZ, Geraldo. Desenho industrial da Escandinávia. O Estado de São Paulo, 14 de março de 1971.

DOCUMENTOS PRESENTES NO ACERVO HISTÓRICO Carta da Associação Brasileira de Desenho Industrial $(A B D I)$ ao International Council of Societies of Industrial Design (ICSID).

Carta de Carmem Portinho, diretora da ESDI, à Pietro Maria Bardi

Catálogo da Exposição. 
WARCHAVCHIK E AS ORIGENS

DA ARQUITETURA MODERNA NO BRASIL

Título dA EXPOSIÇão

DATA E LOCAL

Realizada no ano de 197| no Museu de Arte de São Paulo (MASP)

REFERÊNCIA ARQUIVO HISTÓRICO DO MASP Caixa I /Pasta 4

Diretor da institulção No PERíodo

Pietro Maria Bardi

TEMA DA EXPOSIÇ̄̃̃o (PALAVRA-ChAVE)

Warchavchik, arquitetura moderna brasileira, móvel moderno brasileiro

CurAdores ou responsávels Pelo

PROJETO DA EXPOSIC̃̃O

Pietro Maria Bardi, Lina Bo Bardi

OBjetIVO do EVENTO

A exposição é uma homenagem ao

arquiteto Gregori Warchavchik e à sua

obra pioneira para o início da produção de

rquitetura moderna brasileira.

MATERIAL EXPOSITIVO

80 painéis com fotografias; maquetes

recortes da imprensa, no momento em que

houve a publicação, em 1925, do primeiro

manifesto em defesa da arquitetura funcional

no Brasil de Warchavchick. Também foi exibido

o mobiliário de autoria do arquiteto.

FORTUNA CRÍTICA

MENDES, Oswaldo. Eis um dos pioneiros da

nossa arquitetura. Ulitima Hora, 4 de agosto de

|97I.

Warchavchik: a arquitetura perde um pioneiro. 0 Estado de S. Paulo, 28 de julho de 1972.

Warchavchik mostra seu trabalho pioneiro. Rio de Janeiro, Última Hora, 16 de novembro de 1971.

Um homem em busca da máquina de morar.

Estado de S. Paulo, 10 de agosto de |97|.

Estas fotos foram um escândalo há 40 anos.

Estado de S. Paulo, 9 de agosto de 1971.

Mostra Warchavchik abre amanhã. O Estado de S. Paulo, 8 de agosto de |97|.

Zilda Telles Ferreira Informa. $\mathrm{O}$ Dia, 12 de agosto de $|97|$

FERRAZ, Geraldo. O coordenador do progresso.

O Estado de S. Paulo. 


\section{Mobiliário Brasileiro - Premissas e Realidade}

TITULO DA EXPOSIÇÃO

DATA E LOCAL

Inaugurada em 30 de novembro de 1971

ao final de dezembro no Museu de Arte de São Paulo (MASP)

REFERÊNCIA ARQUIVO HISTÓRICO DO MASP

Caixa 2 /Pasta 12 e 13

Diretor da instituiç̃o no período

Pietro Maria Bardi

TEMA DA EXPOSIÇAO (PALAVRA-CHAVE)

Mobiliário Brasileiro

Curadoreses ou responsávels pelo

PROJETO DA EXPOSICÃO

Pietro Maria Bardi e Lina Bo Bard

OBjeTIVO DO EVENTO

São as palavras de Pietro Maria Bard

que melhor explicam o objetivo da

exposição:“(...) É um convite à reflexão

sobre o problema. Ao mesmo tempo uma

homenagem aos modernos dos séculos

XVII e XVIII que deixaram belíssimas

embranças da atualidade das épocas

da nossa formação, e uma anotação da

vontade de atuação dos designers e

dos industriais que estão procurando

competir e vencer certames no estrangeiro,

ganhando prêmios, obtendo patentes e

exportando o fruto de nosso labor.(...)"

MATERIAL EXPOSitivo

Peças contemporâneas de mobiliário brasileiro e de diversos períodos históricos.

FORTUNA CRÍTICA

lugar do móvel moderno é o museu?

Folha de S. Paulo, 7 de dezembro de 197I.

Um pouco de história na exposição de móveis.

O Estado de S. Paulo, 30 de novembro de 1971.

Museu inaugura mostra do mobiliário.

O Estado de S. Paulo, 30 de novembro

de $197 \mid$

Exposição do mobiliário brasileiro.

Diário de S. Paulo, 30 de novembro

de 1971

Mobiliário Brasileiro. Diário de s. Paulo, domingo, 5 de dezembro de |97|.

A história do Mobiliário Brasileiro está no Masp.

Popular da Tarde, $1^{\circ}$ de dezembro

de |97|.

Os móveis para quem não gosta de coisas velhas.

ornal do Bairro, São Paulo,

। de dezembro de $197 \mid$

BARDI, Pietro Maria. O Mobiliário

Brasileiro. In: Catálogo da exposição Mobiliário Brasileiro - Premissas e Realidade. Museu de Arte de São Paulo, Novembro/Dezembro de 1971. 


\section{Push Pin Studio}

Título da eXPosição

Data e LOCAL

De I4 de agosto a 14 de setembro de 1972

no Museu de Arte de São Paulo (MASP)

ReFERÊnCIA ARQUIVO HISTÓRICO DO MASP

Caixa 4/ Pasta 18

DiRETOR DA INSTITUIÇÃO NO PERÍODO

Pietro Maria Bardi

TeMA DA EXPosição (PALAVRA-CHAVE)

Push Pin Studio

CURADORES OU RESPONSÁVEIS PELO

Pietro Maria Bardi, Lina Bo Bardi,

Olivetti do Brasil S.A. e Push Pin Studio

OBjetivo do EVENTO

Por meio do patrocínio da Olivetti,

é trazida ao Brasil a produção gráfica

e

e Seymour Chwast, escritório norte-

e Seymour Chwast, escritório norte-

americano, um dos mais influentes à

apresentava o uso de uma grande variedade

de estilos e técnicas. Uma linguagem

consoante com o pluralismo da sociedade

contemporânea a sua produção, estabelecendo

uma ruptura às escolas onde predominavam

rígidas regras para a concepção. Milton

Glaser também esteve no Brasil na ocasião da exposição.

MATERIAL EXPOSITIVO

São expostas 670 peças produzidas pelo Push Pin Studio

FORTUNA CRÍTICA

The Push Pin Style.A maior e melhor mostra de artes gráficas do mundo será inaugurada hoje em São Paulo. São os trabalhos do Push Pin Studios. O Estado de S. Paulo, segunda-feira, I4 de agosto de 1972

A maior cabeça do desenho. $O$ Estado de S. Paulo, terça-feira, I 5 de agosto de 1972.

Olivetti apresenta Push Pin Studio.

Diário Popular, I3 de agosto de 1972. 
Desenho Industrial da Argentina

Título da EXPOSIÇÃo

DATA E LOCAL

De 22 de maio de 1973 a 15 de junho

de 1973, no Museu de Arte de São Paulo

(MASP)

REFERÊNCIA ARQUIVO HISTÓRICO DO MASP

Caixa 2 /Pasta 8

DiRETOR DA INSTITUIÇÃo NO PERÍODO

Pietro Maria Bardi

TEMA DA EXPOSIÇ̃̃o (PALAVRA-CHAVE)

Desenho Industrial da Argentina

CuRADores ou RESPONSÁVEIS PELO

Projeto Da eXposicão

Pietro Maria Bardi, Lina Bo Bardi.

OBjetivo do EVENTO

objetivo do evento é apresentar por

meio de sua produção o desenvolvimento

do design na Argentina.

MATERIAL EXPOSITIVO

Objetos e utensílios de 38 indústrias argentinas.

FORTUNA CRÍTICA

Argentina no Desenho Industrial. Folha de S.

Paulo, 26 de maio de 1973.

No Museu da Paulista, o desenho industrial da

Argentina. Folha da Tarde, 26 de maio de 1973. 


\section{A IDEIA Braun}

Título da EXPOSIÇÃO

DATA E LOCAL

Realizada em julho de 1974, no Museu de Arte de São Paulo (MASP)

REFERÊNCIA ARQUIVO HISTÓRICO DO MASP Caixa 3 /Pasta 15

DiRETOR DA INSTITUIÇÃo NO PERÍODO

Pietro Maria Bardi

Tema da exposição (palavra-chave)

Design, Braun

CurAdores ou RESPonsáVEIS PELO

ROIETO DA

Pietro Maria Bardi, Lina Bo Bardi,

Associação Brasileira

de Desenho Industrial (ABDI).

OBJETIVO DO EVENTO

A exposição tinha como objetivo

A exposiça tinha como ot

apresentar as origens do design moderno,

retomando a experiência da Bauhaus e da

Escola de Ulm, a partir da apresentação
dos produtos desenvolvidos pela Braun,

que em 1955, iniciara sua expansão quando

contratara designers ligados a Ulm. A Braun

não somente iniciaria a venda de seus

produtos no País a partir do mesmo ano

como também tinha intenções de iniciar, no ano seguinte, em 1975, a construção de uma unidade fabril no Brasil, a oitava do grupo Braun.

MATERIAL EXPOSITIVO

Objetos produzidos pela indústria Braun.

FORTUNA CRÍTICA

O design de Braun. Veja, 24 de julho de 1974 PENTEADO, João Ricardo. Braun no Brasil. Última Hora, I 5 de julho de 1974.

Sintese de conceitos e soluções. A Gazeta, 18 de julho de 1974

No Masp, a mais nova arte o "Design".

O Estado de S. Paulo, I8 de julho de 1974.

“Idéia Braun”. Última hora, 12 de julho de 1974.

O design valorizado. Visão, 5 de agosto de 1974

Braun: Uma perspectiva histórica. Serviço de

Imprensa. Castelo Branco, Borges e Associados Propaganda S.A. Departamento de Jornalismo e Projetos Especiais. 
Emilie Chamie - trabalhos gráficos,

FOTOGRÁFICOS E PROGRAMAÇÃO VISUAL

TíTULO DA EXPOSIÇÃo

DATA E LOCAL

De I5 de julho a 4 de agosto de 1974 no

Museu de Arte de São Paulo (MASP)

REFERÊNCIA ARQUIVO HISTÓRICO DO MASP

Caixa 3 / Pasta 18

DiRETOR DA INSTITUIÇÃo NO PERÍODO

Pietro Maria Bardi

TEMA DA EXPosição (palaVra-ChaVE)

Emilie Chamie

CuRADORES OU RESPONSÁVEIS PELO

PROJETO DA EXPOSICYÃO

Pietro Maria Bardi, Lina Bo Bardi e SENA

OBJETIVO DO EVENTO

A exposição trouxe uma retrospectiva dos melhores trabalhos gráficos realizados por

Emilie Chamie entre os anos de 1954

1974. Emilie frequentou os cursos do IAC

974. Emilie frequentou os cursos do IAC

MASP nos anos 1950 e seus trabalhos, com
forte presença da linguagem modernista,

também destacaram-se, sobretudo,

pela prevalência da expressão artística

os aspectos puramente técnicos. É

ustamente para esta caracteristica que

Justame

ção no

texto presente no catálogo da exposição:
“(...) Gráfica limpa, jamais rabiscada e virtuosística, numa declinação atenta de valores conjugados à facilidade de entender rápido e fácil. Ideação e produção são intimamente interligados, tendo presente um design como expressão de arte, não de prática técnica. (...).”

Material expositivo

Seleção dos melhores trabalhos de Emilie Chamie entre 1954 e 1974.

FORTUNA CRITICA

Museu expõe obras gráfica. Estado de S. Paulo. Domingo, 14 de julho de 1974

BARDI, Pietro Maria. Emilie Chamie trabalhos gráficos, fotográficos, programação visual. Museu de Arte de São Paulo Assis

Chateaubriand. 15 de julho a 04 de agosto de 1974. 


\section{Retrospectiva John Graz}

Título da EXPOSIÇão

DATA E LOCAL

Aberta em 29 de outubro de 1974, no

Museu de Arte de São Paulo (MASP)

REFERÊNCIA ARQUIVO HISTÓRICO DO MASP

Caixa 2 / Pasta 6

DIRETOR DA INSTITUIÇÃO NO PERÍODO

Pietro Maria Bardi

TEMA DA EXPOSIÇÃO (PALAVRA-CHAVE)

John Graz, pintura, arquitetura de interiores

MATERIAL eXPositivo

Pinturas, fotografias de interiores e objetos de design de John Graz.

ForTUNA CRÍTICA

Retrospectiva mostra a obra de John Graz.

Estado de S. Paulo, 28 de outubro de 1974.

John Graz. Estado de S. Paulo, 29 de outubro de 1974.

CURADORES OU RESPONSÁVEIS PELO

PROJETO DA EXPOSICÃO

Pietro Maria Bardi, Lina Bo Bardi

OBJETIVO DO EVENTO

Em continuidade ao programa de

apresentação de artistas de outra

gerações, como Gregori Warchavchick, o

Museu dedica uma exposição retrospectiva

à obra de John Graz, na sua dupla atividade,

de pintor e de arquiteto de interiores. 


\section{DIDÁTICA '75 DO IADÊ}

Título dA EXPOSIÇÃo

DATA E LOCAL

De 08 de outubro a 02 de novembro de

1975 Museu de Arte de São Paulo (MASP)

REFERÊNCIA ARQUIVO HISTÓRICO DO MASP

Caixa I / Pasta 7

DIRETOR DA INSTITUIÇÃO NO PERÍODO

Pietro Maria Bardi

TEMA DA EXPOSIÇÃo (PALAVRA-CHAVE)

Colégio Industrial IADÊ

Curadores ou responsávels pelo

PROJETO DA EXPOSIÇÃO

P. M. Bardi, Lina Bo Bardi, Colégio Industrial

IADÊ.

OBJETIVO DO EVENTO

O Museu apresentou a exposição IADÊ,

formada pela exibição dos trabalhos

de alunos da escola, com o objetivo

de sublinhar sua importância.A escola

produziu inúmeros profissionais atuantes

no campo do desenho aplicado.

MATERIAL EXPOSITIVO

40 trabalhos dos alunos da Escola Industrial IADÊ

FORTUNA CRÍTICA

Didática '75. IADE O estado de S. Paulo, 20 de outubro de 1975. 


\section{Lívio Edmondo Levı ( 1933 - I973)}

TíTULO DA EXPOSIÇÃO

DATA E LOCAL

De 8 de maio a 28 de maio de 1975 no Museu de Arte de São Paulo (MASP)

REFERÊNCIA ARQUIVO HISTÓRICO DO MASP Caixa 2 / Pasta 10

DiRETOR DA InSTITUIÇÃo No PERÍOdO

Pietro Maria Bardi

TEMA DA EXPOSIÇÃO (PALAVRA-CHAVE) Lívio Levi, arquitetura, designer de joias, iluminação

\section{CURADORES OU RESPONSÁVEIS PELO}

PROJETO DA EXPOSIÇÃO

Museu de Arte de São Paulo (MASP) Instituto dos Arquitetos do Brasil São Paulo (IAB - SP) e Associação Brasileira de Desenho Industrial (ABDI)

OBIETIVO DO EVENTO

Em homenagem à obra do arquiteto e designer Lívio Edmondo Levi,

prematuramente falecido em 1973, O

Museu, conjuntamente com o IAB - SP e

a $A B D I$, organiza a exposição composta

em grande parte por painéis fotográficos que documentavam sua a obra arquitetônica, os projetos de iluminação, luminárias e joias de Lívio que o celebrizaram.

Material eXPositivo

Projetos de edifícios, fábricas, decorações de interiores, objetos de uso doméstico e joias. Aproximadamente, 33 fotografias de obras de iluminação, 7 luminárias e entre as joias, registraram-se: 9 colares, 3 pulseiras, 5 anéis, 4 abotoadeiras e 4 brincos.

FORTUNA CRITICA

Obras de Livio Levi na exposição. O Estado de São Paulo, $I^{\circ}$ de maio de 1975.

Uma mostra em homenagem a este arquiteto $\mathrm{e}$ designer. Jornal da Tarde, I0 de maio de 1975.

Na retrospectiva, uma homenagem a Lívio.

O Estado de S. Paulo, I8 de maio de 1975. 
Cédulas do Brasil

TítULO DA EXPOSIÇÃo

DATA E LOCAL

Realizada em 1975 no Museu de Arte de São Paulo (MASP)

ReFERÊNCIA ARQUIVO HISTÓRICO DO MASP

Caixa 3 / Pasta 18

DiRETOR DA InstituIÇÃO NO PERÍODO

Pietro Maria Bardi

TEMA DA EXPOSIÇÃO (PALAVRA-ChAVE)

Cédulas

CURADORES OU RESPONSÁVEIS PELO

PROJETO DA EXPOSIÇÃO

Museu de Arte de São Paulo, Museu de

Valores, Banco Central do Brasil..

OBJETIVO DO EVENTO

A exposição teve como objetivo divulgar

o papel moeda brasileira. A mostra

o papel moeda brasile

modo a permitir ao visitante tomar um

modo a permitir ao visitante tomar um
conhecimento dos tipos de cédulas que

circularam no País, seus fabricantes e como

se desenvolve o processo de fabricação do

dinheiro de papel.

MATERIAL EXPOSITIVO

Cédulas de moeda brasileira. 
RHODIA

Titulo dA EXPOSIÇÃO

Data e local Ocorre no Museu de Arte de São Paulo (MASP), porém não foram localizadas datas no arquivo histórico do Museu.

REFERÊNCIA ARQUIVO HISTÓRICO DO MASP Caixa 04/ Pasta 28

DiRETOR DA INSTITUICÃ̃o NO PERÍODO

Pietro Maria Bardi

TEMA DA EXPOSIÇÃo (PALAVRA-ChAVE)

Tecidos, moda, Rhodia

Curadores ou responsávels pelo

PROJETO DA EXPOSIÇÃO

Pietro Maria Bardi, Lina Bo Bardi, e Rhodia Indústrias.

OBJETIVO DO EVENTO

O Museu, ao homenagear a experiência da Rhodia nos anos 1950, momento em que a empresa convidou inúmeros artistas plásticos para o aprimoramento dos desenhos para tecidos, retoma o debate das relações entre arte e indústria. $A$

experiência da Rhodia e considerada um modelo exemplar de entrosamento um modelo exemplar de entrosar arte e indústria no País.
MATERIAL EXPOSITIVO Vestidos com estamparias assinadas por artistas plásticos brasileiros.

ForTUNA CRÍTICA O professor Bardi, diretor do Museu de Arte de São Paulo, está posando, na foto, com um modelo do artista Nelson Leirner. Jornal

da Tarde, quinta-feira, 20 de maio de 1976. 
INDIVIDUAL José ZANINE CALDAS

Título dA EXPOSIÇÃo

DATA E LOCAL

Individual José Zanine Caldas realizada

em 1975 no Museu de Arte de São Paulo

(MASP).

REFERÊNCIA ARQUIVO HISTÓRICO DO MASP

Caixa 2 /Pasta 13

Dinstituicão no PEŔ́ODO

Pietro Maria Bardi

TEMA DA EXPOSIÇÃO (PALAVRA-CHAVE)

osé Zanine Caldas, Design

\section{CuRADORES OU RESPONSÁVEIS PELO}

PROJETO DA EXPOSIÇ̃̃O

P. M. Bardi, Lina Bo Bardi, Instituto de

Arquitetos do Brasil - São Paulo.

OBjetIVO DO EVENTO

A exposição, exibida primeiramente no

Museu de Arte Moderna do Rio de Janeiro

(MAM RJ), é dedicada a apresentar a

(MAM RJ), é dedicada a apresentar a
produção de móveis de Zanine. A mostra

produção de móveis de Zanine.A mostra

teve como objetivo retomar a questão do

na qual ele já não tem o domínio completo

do processo produtivo do que constrói;

bem como demonstrar novamente, por meio do trabalho do designer,

a possibilidade de criar objetos a partir da ideia

de uma "estética brasileira", na qual

o uso de materiais e elementos da nossa

cultura estão presentes.

Material expositivo

Móveis elaborados por José Zanine.

FORTUNA CRÍTICA

Zanine, o homem que ainda faz coisas. Jornal da

Tarde, 28 de outubro de 1975.

Velhos troncos que viram móveis úteis. Folha de $\mathrm{S}$. Paulo, 24 de outubro de 1975.

Zanine - Ele faz móveis de restos de madeira e com liberdade. O Estado de S. Paulo, 23 de outubro de 1975 .

Móveis de Zanine do Museu de Arte Moderno.

O Globo, domingo, 20 de abril de 1975. 
DesenHo INDUSTRIAL ITALIANO

Título dA EXPOSIÇÃo

DATA E LOCAL

De 22 de outubro a 16 de novembro de

1975, no Museu de Arte de São Paulo

(MASP)

REFERÊNCIA ARQUIVO HISTÓRICO DO MASP

Caixa $3 /$ Pasta 17

iretor da instituicão no período

Pietro Maria Bardi

TEMA DA EXPOSIÇÃo (PALAVRA-CHAVE)

Design Industrial Italiano

Curadores ou responsávels pelo

PROJETO DA EXPOSIÇ̃̃O

P. M. Bardi, Lina Bo Bardi, Ministério das

Relações Exteriores da Itália, Embaixada da

Itália no Brasil, Consulado Geral da Itália

em São Paulo, Comissão Executiva para as

comemorações do centenário da imigração

italiana, Olivetti do Brasil S.A.
OBjeTIVO do EVENTO

A exposição proposta pelo Museu, com

apoio do Ministério Estrangeiro Italiano e da

Sociedade Olivetti, fez parte dos eventos em

torno da comemoração do $1^{\circ}$ Centenário

da Imigração Italiana no Brasil. A exposição

teve como objetivo apresentar a produção

italiana de design, que ocupava papel de

destaque no panorama internacional do campo, simbolizando novos rumos à disciplina.

Material eXPositivo

Objetos feitos por designer italianos de três gerações diferentes.

FORTUNA CRÍTICA

Neste bom design, um milagre industrial. Jornal da Tarde, 22 de outubro de 1975.

Design Italiano. Folha de São Paulo, 26 de outubro de 1975.

"Design" italiano: belo e útil nas mesmas peças.

Folha de São Paulo, 2 de novembro de 1975. 
DATA E LOCAL

Realizada no mês de maio de 1976 no Museu de Arte de São Paulo (MASP)

REFERÊNCIA ARQUIVO HISTÓRICO DO MASP Caixa 4/ Pasta 18

DiRETOR DA INSTITUIÇÃo NO PERÍODO

Pietro Maria Bardi

Tema da exposição (palaVra-chaVe)

Arte, Olivetti

CURADORES OU RESPONSÁVEIS PELO

PROJETO DA EXPOSIČÃO

Pietro Maria Bardi, Lina Bo Bardi e

Olivetti Industrial S.A.

OBjetIVO do EVENTO

Mais uma vez contribuindo para a discussão

das relações entre arte e indústria, a

Olivetti apresenta a exposição de diversas

obras de arte de seu acervo, encomendadas

pela empresa ao longo dos anos, para

três fins: reproduções nas agendas da

companhia; reproduções em livros editados

por ocasiões de assembleias, seminários

e conveni

convenios e para suprir as necessidades

nternas de decoração dos escritórios da

empresa.
MATERIAL EXPOSITIVO

170 trabalhos de diversos artistas em pintura

acrílica sobre tela, aquarelas, litografias,

aguafortes, gravuras, serigrafias, esculturas,

desenhos, entre outros.

FORTUNA CRÍTICA

Grandes nomes da Arte Contemporânea.

Jornal da Tarde, sábado, 8 de maio de 1976.

Mostra ilustra as relações entre $a$ arte e $a$

indústria. O Estado de S. Paulo, sábado, 8 de

maio de 1976.

Fatti di Cultura, gli artisti e l'Olivetti. Corriere

Italo-brasiliano. S. Paolo, 28 de maio de 1976.

No Masp, outro rico acervo internacional. Diário

da Noite, sexta-feira, 7 de maio de 1976. 


\section{Desenho Industrial FinLANDÊS}

Título dA EXPOSIÇÃo

DATA E LOCAL

De 06 de julho a $1^{\circ}$ de agosto de 1976, no

Museu de Arte de São Paulo (MASP)

REFERÊNCIA ARQUIVO HISTÓRICO DO MASP

Caixa I /Pasta 8

DiRETOR DA Instituição No PERÍOdo

Pietro Maria Bardi

TEMA DA EXPOSIÇÃo (PALAVRA-CHAVE)

Design Industrial Finlandês

CurAdores oU RESPONSÁVEIS PELO

P. M. Bardi, Lina Bo Bardi, Museu de Arte

Moderna do Rio de Janeiro (MAM RJ) e

Consulado Finlandês.

OBJETIVO DO EVENTO

A exposição apresentada no Museu fora

A exposiço apresenta

antes apresentada

da comemoração do Centenário da

Sociedade Finlandesa de Artes e Desenho

Industrial. Por meio da apresentação de

trabalhos de trinta designers finlandeses

pretendia-se exibir uma produção industria

cujas origens remetem-se à forte tradição

de artesanato do País.
MATERIAL EXPOSitivo

Objetos elaborados por trinta designers

finlandeses, entre eles, Tapio Wirkalla,Timo Sarpaneva e Antii Murmesniemi.

FORTUNA CRÍTICA

Flores no prato. Veja n.390, 25 de fevereiro de 1976.

O design industrial finlandês, em exposição no Masp. Folha de S. Paulo, 7 de julho de 1976 
FIRMA ITÁLIA - ARTE, CINEMA, GRÁFICA, PUBLICAÇÕES, TELEVISÃO NA COMUNICAÇÃO INDUSTRIAL ITALIANA

Título DA EXPOSIÇÃo

DATA E LOCAL

De 23 de novembro a 2 de dezembro

de 1977, no Museu de Arte de São Paulo (MASP)

REFERÊNCIA ARQUIVO HISTÓRICO DO MASP Caixa 2 /Pasta 3

Diretor da InSTITUIČ̃o no PERÍODO

Pietro Maria Bardi

TEMA DA EXPOSIÇÃO (PALAVRA-CHAVE)

Itália

Curadores ou responsávels PELO

PROJETO DA EXPOSIÇÃO

P. M. Bardi, Lina Bo Bardi, Firma Itália, Embaixada da Itália no Brasil.

OBJETIVO DO EVENTO

A A exposição proposta, além de traze a produção recente italiana dedicada à

construção da imagem das indústrias

italianas por meio da comunicação, retoma a problemática das relações entre arte-

indústria, tema caro ao Museu e, dirigia-se

não somente aos que atuavam nos campos

da comunicação, do design e ao público,

mas particularmente aos industriais,

à classe produtora brasileira.Após a apresentação no MASP, a exposição foi exibida no MAM RJ.

MATERIAL EXPOsitivo

A comunicação das maiores empresas italianas.

FORTUNA CRÍTICA

I pubblicitari e la crisi dela pubblicità. Mario L. Savarse. Gli uomini dela publicità. L'Ufficio Moderno, Milano, n. 5, 1977.

In Brasile arte e gráfica nella comunicazione industriale italiana. II Sole 24 Ore, 6 lugllo 1977.

Una mostra italiana in Brasile su "arte, cinema, gráfica e publicità nella comunicazione industriale". | Fiorino, I5 luglio 1977.

"Firma Italia" a novembre in Brasile.Vita, 3 agosto 1977 
DATA E LOCAL

De $1^{\circ}$ de março a 3 de abril de 1977 , no

Museu de Arte de São Paulo (MASP)

\section{REFERÊNCIA ARQUIVO HISTÓRICO DO MASP}

Caixa 4 /Pasta 26

DiRETOR DA INSTITUIÇÃO NO PERÍODO

Pietro Maria Bardi

Tema da eXPosição (palavra-chaVE)

De Stijl, arte holandesa

Curadores ou responsáveIS PELO

PROJETO DA EXPOSICÃO

P. M. Bardi, Lina Bo Bardi, Consulado

dos Países Baixos.

OBjeTIVO DO EVENTO

O Movimento De Stijl, “O Estilo”,

fundado em 1917 por seis artistas

holandeses é apresentado em retrospectiva

pelo Museu por meio de painéis

explicativos com as manifestações do

movimento nas várias áreas de expressão

artística, como no design, na arquitetura,

pintura, escultura e cinema.
Material eXpositivo

Obras do movimento De Stijl expostos

no formato de 36 painéis de I,00 × I,40

$\mathrm{m}$ e curtas sobre a arte holandesa. Foram

expostas também obras de coleções privadas

holandesas.

FORTUNA CRÍTICA

* No acervo histórico foram encontrados

mais artigos, porém sem registro das fontes

de origem. 
Gráfica Italiana Contemporânea

Título dA EXPOSIÇÃo

DATA E LOCAL

De 5 de janeiro a 14 de fevereiro de 1977

no Museu de Arte de São Paulo (MASP)

REFERÊNCIA ARQUIVO HISTÓRICO DO MASP

Caixa 2 / Pasta II

DiRETOR DA InSTITUIÇÃo No PERÍOdO

Pietro Maria Bardi

TeMA dA EXPosição (PALAVRA-CHAVE)

Desenho gráfico italiano

CurAdores OU RESPONSÁVEIS PELO

PROJETO DA EXPOSIÇC̃O

Pietro Maria Bardi, Lina Bo Bardi

IIC (Istituto Italiano di Cultura)

OBJETIVO DO EVENTO

Não há como evidenciá-lo, uma vez que

faltam fontes sobre a exposição. No

arquivo histórico do Museu há somente o

registro dos autores das 150 reproduções

exibidas.

MATERIAL EXPOsitIVO

150 reproduções 


\section{Panorama da IDEntidade Nacional}

TítULO DA EXPOSIÇÃo

DATA ELOCAL

7 a 10 de novembro de 1977 no Museu de

Arte de São Paulo (MASP)

REFERÊNCIA ARQUIVO HISTÓRICO DO MASP

Caixa 4 / Pasta 20

DiRETOR DA INSTITUIÇÃO NO PERÍODO

Pietro Maria Bardi

Tema da exposição (palaVra-chaVe)

Panorama da Identidade Nacional Empresarial

CurAdores ou RESPONSÁVEIS PELO

PROJETO DA EXPOSICCÃO

P. M. Bardi, Lina Bo e Marco Antonio

Amaral Rezende (presidente da Associação

Brasileira de Desenho Industrial ABDI)

OBJETIVO DO EVENTO

A exposição Panorama da Identidade Visual teve como proposta, por meio da exibição de inúmeros programas de identidades visuais de empresas brasileiras, analisar as diversas questões e conceitos referentes à elaboração e implantação de programas de identidade visual, uma das principais áreas de atuação visual, uma das principais

\section{Material expositivo}

Programas de Identidade Visual de empresas brasileiras expostos em painéis de cartão supremo de $0,66 \times 0,96 \mathrm{~m}$ na vertical. 
Origens dA IndustrializAÇÃo

eM São Paulo

TítULO DA EXPOSIÇão

DATA E LOCAL

De 9 a 29 de agosto de 1977 no Museu de Arte de São Paulo (MASP)

REFERÊNCIA ARQUIVO HISTÓRICO DO MASP Caixa 4 / Pasta 27

DiRETOR DA InSTITUIÇÃo No PERÍOdO

Pietro Maria Bardi

TEMA DA EXPosiç̄̃o (PALAVRA-ChaVE)

Industrialização, São Paulo

CuRADORES OU RESPONSÁVEIS PELO

PROJETO DA EXPOSIIÇÃO

Pietro Maria Bardi, Ana Luisa Escore

(projeto e realização), Lauro Escorel

(Coordenação da pesquisa iconográfica),

Departamento de Ciências Sociais do

Instituto de Filosofia e Ciências Humanas

(IFCH) da Universidade Estadual

de Campinas.

OBIETIVO DO EVENTO

A exposição Origens da Industrialização

em São Paulo integrava o projeto

de pesquisa Imagens e História da

Industrialização no Brasil, cujo objetivo

era preservação da memória do processo

industrial. Por meio da localização de

documentos, da iconografia e da coleta de depoimentos, da história oral; a exposição tinha como objetivo o convite ao apoio da sociedade como um todo $e$

a persuasão, na medida em que a tarefa era plenamente realizável, desde que com o apoio dos diferentes setores da sociedade.

\section{MATERIAL EXPOSITIVO}

Cerca de 300 fotos relativas ao período

de 1910-1930. Alguns filmes também foram expostos.

DOCUMENTOS

ESCOREL,Ana Luísa. Objetivos da Exposição.

Acervo Histórico do Museu. 
DATA E LOCAL

De II a 20 de agosto de 1978 no Museu

de Arte de São Paulo (MASP)

REFERÊNCIA ARQUIVO HISTÓRICO DO MASP

Caixa 8 / Pasta 47

DiRETOR DA INSTITUIÇÃO NO PERÍODO

Pietro Maria Bardi

Tema da exposição (palaVra-chaVe)

Vidro

CuRADORES OU RESPONSÁVEIS PELO

P. M. Bardi, Companhia Produtora de Vidro PROVIDRO e CÁ D'ORO LTDA. Cristais Artísticos

OBjeTIVO DO EVENTO

A partir de uma abordagem histórica

foram exibidas peças de vidro, cuja

A partir de uma aborda

remontava até mesmo a Antiguidade. Um

forno em funcionamento também fez parte

da exposição como forma de ilustrar o

processo de fabricação do vidro.
ATERIAL EXPOSITIVO

Exposição de peças antigas de vidro, fabricação de artigos de vidro colorido, projeção do filme "Coração de Cristal" de Werner Herzog.

\section{FORTUNA CRÍTICA}

vidro, desde os faraós até os astronautas. Jorna da Tarde, II de agosto de 1978.

“Glass Week" In SP. Brazil Herald, I 3 //4 de agosto de 1978.

Glass Exhibit. Brazil Herald, I I de agosto de

1978 
LINHA DE MÓVEIS INNOVATOR

Título dA EXPOSIÇÃo

DATA E LOCAL

16 a 19 de março de 1978 no Museu de Arte de São Paulo (MASP)

REFERÊNCIA ARQUIVO HISTÓRICO DO MASP Caixa 2 / Pasta 6

DIRETOR DA INSTITUIÇÃO NO PERÍODO

Pietro Maria Bardi

TEMA DA EXPOSIÇÃo (PALAVRA-CHAVE)

Mobiliário

CurAdores ou responsávels pelO

PROJETO DA EXPOSIÇÃO

Pietro Maria Bardi, Lina Bo Bardi

OBjetivo do EVENTO

Os móveis da linha Innovator, criados

na Suécia por dois jovens arquitetos,

Jan Dranger e Joahn Huldt, era lançado

no mercado brasileiro e comercializado

pelas Tok Stok. A exposição foi uma

pelas Tok Stok. A exposição foi uma
oportunidade de apresentá-los, na medida

oportunidade de apresentá-los, na medida

em que estes, já há dez anos no mercado

no mundo inteiro, pelo uso mínimo de

material em todo o seu processo de

execução, de estruturas metálicas de fácil

montagem, almofadas removíveis e laváveis

e, portanto, custo menor ao usuário final.

MATERIAL EXPOSITIVO

Móveis da nova linha Inovattor de design sueco.

FORTUNA CRÍTICA

No Masp, a vez dos móveis. Março de 1978.

$O$ novo sofá-cama tem desenho neutro para

combinar com a decoração. Jornal do Brasil, junho de 1979.

Decoração. Caderno B. Jornal do Brasil, Rio de Janeiro, domingo, 22 de julho de 1979. 


\section{HISTÓRIA DA TIPOGRAFIA NO BRASIL}

TítULO DA EXPOSIÇÃO

DATA E LOCAL

3 de março às $20 \mathrm{~h} 30$ a 14 de abril de

1979, no Museu de Arte de São Paulo

(MASP)

REFERÊNCIA ARQUIVO HISTÓRICO DO MASP

Caixa I.I/ Pasta 4

iretor da instituição no período

Pietro Maria Bardi

TEMA DA EXPOSIÇAO (PALAVRA-CHAVE)

Tipografia no Brasil

Curadores ou responsávels pelo

PROJETO DA EXPOSIÇÃO

P. M. Bardi, Cláudia Mariano Semeraro,

Christiane Ayrosa, Secretaria de Cultura,

Ciência e Tecnologia do Estado de São

Paulo, Coleção Áurea e Carlos Rizzini, José

Mindlin e Rubens Borba de Moraes.

OBJETIVO do EVENTO

A exposição proposta pelo Museu bem como o livro-catálogo História da

Tipografia no Brasil produzido na ocasião,

tiveram como objetivo propor a reflexão

sobre as relações entre a expressão escrita,

a gráfica e a política no contexto brasileiro'

a partir da reunião de um vastíssimo

material: capas de livros, famílias tipográficas reproduções de vinhetas, anúncios e livros

como forma de evidenciar o desenvolvimento dos processos de impressão no País.

MATERIAL EXPOSITIVO

Foram expostos: o primeiro trabalho impresso clandestinamente (1747), as publicações da Impressão Régia, diversas iniciativas ocorridas nas Províncias até importantes obras

contemporâneas de tiragem limitada. Jornais e revistas com caricaturas, livros literários e científicos, diplomas, partituras musicais e rótulos.

FORTUNA CRÍTICA

A censura chegou antes da tipografia.

sto é, 4 de abril de 1979 .

Um pouco da história da tipografia no Brasil. O Estado de S. Paulo, 29 de abril de 1979. Masp: tipografia. O Estado de S. Paulo, 16 de març̧o de 1979.

A tipografia brasileira desde 1747, no Masp. O Estado de S. Paulo, 16 de março de 1979.

Tipografia também conta história

do Brasil no Masp. Folha de São Paulo,

20 de março de 1979. 
1979.

História da tipografia brasileira. Diário de S. Paulo, 3 de abril de 1979.

Masp conta história da tipografia brasileira.

Jornal do Brasil, 4 de abril de 1979.

Uma síntese gráfica da história do Brasil. Folha de S. Paulo, 7 de abril de 1979.

A tipografia no Brasil. Folha de S. Paulo, 8 de abril de 1979.

História da tipografia brasileira. A Província do Pará, Belém, 8 de abril de 1979.

Fora de comércio. A Tarde, Salvador, 9 de junho de 1979.

KLINTOWITZ/PINTO. Jacob/ Zélio Alves. A censura chegou antes da tipografia. Isto é, 4 de abril de 1979.

\section{BRITISH POSTERS}

Título da eXPosição

DATA E LOCAL

De 17 de junho a 3 de julho de 1979 no

Museu de Arte de São Paulo (MASP)

REFERÊNCIA ARQUIVO HISTÓRICO DO MASP

Caixa I /Pasta I

DIRETOR DA INSTITUICC̃̃o NO PERÍODO

Pietro Maria Bardi

TEMA DA EXPOSIÇÃ̃ (PALAVRA-CHAVE)

Cartazes ingleses

CURADORES OU RESPONSÁVEIS PELO

PROJETO DA EXPOSIÇÃOO

P. M. Bardi, Lina Bo, Consulado Inglês

no Brasil e Cultura Inglesa.

OBjetIVO DO EVENTO

Parte da coleção de Alan Mabey (1904

- 1976), compreendida por 104 posters

selecionados pela Lord's Gallery, de

Londres, foi exibida no Museu, compondo

uma espécie de história abreviada da

evolução do design gráfico inglês, da virada

do século à II Guerra Mundial.
MATERIAL EXPOSITIVO

104 cartazes

FORTUNA CRÍTICA

Pré-estreia da Semana. O Estado de S. Paulo, segunda-feira, 11 de junho de 1979.

Londres num punhado de cartazes. Folha de $S$. Paulo, 17 de junho de 1979

Posters Britânicos. O Estado, domingo,

17 de junho de 1979.

Da rua ao Museu. No MASP, uma exposição de posters ingleses. Veja, 27 de junho de 1979. 


\section{AleXandre Wollner - Designer Gráfico}

DATA E LOCAL

De 05 a 25 de agosto de 1980 no Museu

de Arte de São Paulo (MASP)

REFERÊNCIA ARQUIVO HISTÓRICO DO MASP

Caixa 15 / Pasta 92

DiRETOR DA INSTITUIÇÃO NO PERÍOdO

Pietro Maria Bardi

TEMA DA EXPOSIÇÃo (PALAVRA-CHAVE)

Alexandre Wollner, design gráfico

CurAdores ou RESPONSÁVEIS PELO

PROJETO DA EXPOSIÇÃO

P. M. Bardi, Lina Bo e Alexandre Wollner.

OBJETIVO DO EVENTO

Na primeira exposição dedicada a sua

obra, ao completar 20 anos de carreira,

Alexandre Wollner não fez a opção por

uma retrospectiva, mas por uma tentativa

de mostrar o processo de criação,

execução e implantação de um programa

de identidade visual, numa postura didática.

MATERIAL EXPOSITIVO

Trabalhos do designer reunidos ao longo

dos 20 anos de sua carreira e expostos

em 40 painéis organizados em duas partes:

uma dedicada ao processo criativo de uma

identidade visual e outra dedicada ao processo

de implantação.

FORTUNA CRÍTICA

A Arte ganha destaque nos próximos dias. Folha de S. Paulo, 3I de julho de 1980.

O ‘design’ de Wollner, em exposição didático.

Sábado, 2 de agosto de 1980.

Artes plásticas. Folha de S. Paulo, 29 de julho de 1980.

Pré-estréia da Semana, por Telmo Martino, amanhã. Jornal da Tarde, 4 de agosto de 1980. Design / IAC.Arte Vogue nI. 
DATA E LOCAL

De 10 outubro a 2 de novembro de 1980

no Museu de Arte de São Paulo (MASP)

ReferênCIA ARQUIVO HISTÓRICO DO MASP

Caixa 5 / Pasta 25

DIRETOR DA INSTITUIÇÃO NO PERÍODO

Pietro Maria Bardi

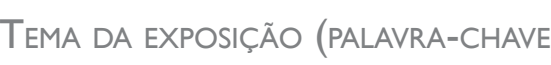

Liberty e Deco Itália

CurADORES OU RESPONSÁVEIS PELO

PROJETO DA EXPOSIÇÃO

P.M Bardi, Lina Bo, Rossana Bossaglia

OBJETIVO DO EVENTO

Por meio da exposição de peças como

vasos Richard-Ginori, móveis no estilo

art nouveau, objetos e pôsteres no estilo

art deco pretendeu-se apresentar um

panorama das artes decorativas na Itália do

final no século XIX e início do XX.

MATERIAL EXPOSITIVO

Cerâmicas, cristais, pôsteres, mobiliário e objeto de uso que caracterizaram o estilo Liberty\&Deco.

FORTUNA CRITICA

Influência italiana e outras mostras. A tribuna 26 de outubro de 1980.

Nas galerias, memórias, reportagem e um pouco da nossa história. O Estado de S. Paulo,

29 de outubro de 1980 
FANTASIAS DE CARNAVAL DA

\section{Escola de Samba Pérola Negra}

Título dA EXPOSIÇÃo

DATA E LOCA

março de 1981, no Museu de Arte de São Paulo (MASP).

REFERÊNCIA ARQUIVO HISTÓRICO DO MASP

Caixa 05/ Pasta 31

DiRETOR DA INSTITUIÇÃO NO PERÍODO

Pietro Maria Bardi

TEMA dA exposição (palaVra-ChaVE)

Fantasias de carnaval, Pérola Negra

CURADORES OU RESPONÁVEEIS

PELO PROJETO DA EXPOSIÇ̄̃O

P. M Bardi, Lina Bo, Maria da Conceição

Cahu, diretoria Pérola Negra, Sr. Luíz Osaka e Eugênia.

OBJETIVO DO EVENTO

Nas palavras de Pietro Maria Bardi:"O

MASP é um museu aberto. Já fizemos

desfiles de moda na pinacoteca e

achamos interessante mostrar todas as

manifestações populares, independentes

de outras atividades do museu. Não é

porque promovemos, futuramente, uma

exposição com obras de Miró, Magritte e

Max Ernst, que devemos esquecer a arte

essencialmente popular. Esta exposição de

fantasias revela aspectos muito interessantes, como a maneira de se confeccionar as roupas,

as alegorias, enfim, como o povo trabalha

para fazer seu Carnaval. Tem um caráter

estritamente didático e documental.’

MATERIAL EXPOSITIVO

Fantasias e objetos utilizados pela Escola

Pérola Negra nos desfiles de carnaval.

FORTUNA CRITICA

Carnaval vira peça de museu.

Folha de S. Paulo, llustrada, 12 de março de

1981.

Depoimento de Pietro Maria Bardi. In: CARNAVAL VIRA PEÇA DE MUSEU.
Ilustrada, 12 de março de 1981. 


\section{Arte Popular do Brasil}

TíTULO DA EXPOSIÇÃo

DATA E LOCAL

De 18 de maio até 12 de julho de 1981 , no

Museu de Arte de São Paulo (MASP)

ReFERÊnCIA ARQUIVO hISTÓRICO do MASP

Caixa 5 /Pasta 29

DiRETOR DA INSTITUIÇÃO NO PERÍODO

Pietro Maria Bardi

TeMa da EXPosição (PALAVRA-CHAVE)

Arte popular brasileira

CURADORES OU RESPONSÁVEIS PELO

PROIETO DA

Pietro Maria Bardi, Lina Bo Bardi

Olivetti Industrial S.A.

OBJETIVO DO EVENTO

A mostra reapresenta a exposição Mão

do Povo Brasileiro, sob o título de Arte

Popular do Brasil, em homenagem

Popular do Brasil, em homenagem à visita

dos Conselheiros Internacionais do Museu

de Arte Moderna de Nova lorque (MOMA

- NY), reunidos em São Paulo para sua

convenção anual. Novamente são exibidos

os mais variados objetos de produção

popular ao lado de peças utilitárias como

alambiques, instrumentos de trabalho e de

uso.Tratava-se de uma oportunidade única para apresentar ao contexto internacional alguns dos aspectos mais característicos

da arte popular brasileira. A mostra teve a

colaboração do SESC, que forneceu seu acervo

de artesanato de todo o Brasil, e de alguns

colecionadores particulares.

MATERIAL EXPOSITIVO

Variados objetos de produção popular

instrumentos de trabalho e de uso.

FORTUNA CRÍTICA

Hoje - No Masp quatro mestres da arte moderno. O Estado de S. Paulo, Jornal da Tarde, 18 de

maio de I98I.

A arte do Brasil, numa mostra muito original.

Estado de S. Paulo, Jornal da Tarde, 19 de maio de $|98|$

Exposições. Folha de S. Paulo, 19 de maio de |981.

De manhã, vá ao Museu do Bexiga ou ao Ibirapuera, se tiver folga; à tarde, não perca Djavan, no Programa do Zuza; à noite, fique gratificado diante das obras de Magrite, Ernst, Miró e De Chirico. Folha de S. Paulo, I8 de maio de 198|. 
Mark Mc Donnell - Vidros

TíTULO DA EXPOSIÇÃO

DATA E LOCAL

De $1^{\circ}$ a 19 de outubro de 1981 no Museu

de Arte de São Paulo (MASP)

REFERÊNCIA ARQUIVO HISTÓRICO DO MASP

Caixa $9 /$ Pasta 52

DIRETOR DA INSTITUIÇÃO NO PERÍODO

Pietro Maria Bardi

TEMA dA EXPOSIÇÃ̃ (PALAVRA-CHAVE)

Mark Mc Donnell, vidros, design

Curadores ou responsávels pelo

PROJETO DA EXPOSIIÇÃO

P. M Bardi, Lina Bo, Raquel Arnaud

OBJETIVO DO EVENTO

$\mathrm{Na}$ exposição foram apresentados 50

objetos em vidro com cores primárias de

autoria de Mark McDonnel, executados a

partir de métodos tradicionais do sopro,

sem o uso de formas e equipamentos

mecânicos, ou seja, um processo artesanal.

E é justamente a valorização do processo

de trabalho com vidro o intuito dessa

exposição.

MATERIAL EXPOSITIVO

Peças de vidro feitas em São Paulo pelo artista

FORTUNA CRÍTIC

Uma arte quase em extinção revivida por

MacDonnell. Folha de São Paulo, I de outubro

de 198

Telmo Martino. Jornal da Tarde, 25 de setembro

de |98|.

Divirta-se. Jornal da Tarde, I de outubro de 


\section{“A PESQUISA DA QUALIDADE: O TERMINAL da Caixa em Tempo Real”}

8 a 20 de dezembro de 1981 no Museu de Arte de São Paulo (MASP)

REFERÊNCIA ARQUivo HISTÓRICO DO MASP Caixa 5/ Pasta27

Diretor da institulção No PERíodo

Pietro Maria Bardi

TEMA DA EXPOSIÇÃO (PALAVRA-CHAVE) design industrial, terminal da caixa

Curadores ou responsávels pelo

PROJETO DA EXPOSIÇÃO

P. M. Bardi, Lina Bo, Cauduro/Martino Arquitetos Associados.

OBjETIVO DO EVENTO

A partir da década de 1970, os

bancos passam a utilizar intensamente

equipamentos eletrônicos no seu

processamento de dados e para

acompanhar este processo, o escritório

Cauduro e Martino apresentam o projeto

Terminal de Caixa em Tempo Real, primeira

expressão no Brasil desse processo. $O$

Terminal, uma máquina autenticadora

ligada a um computador em tempo real,

era capaz de realizar um elevado e complexo conjunto de funções. A exposição apresenta o projeto desenvolvido, como demonstração da capacidade e importância do design à indústria brasileira, na medida em que a disciplina se

configura como um instrumento de negócios

traduzido em qualidade tecnológica invisível e

visível do produto.

Material expositivo

Projeto do Terminal de Caixa em Tempo Real.

FORTUNA CRITICA

Um dia de bom humor para as artes.

Jornal da Tarde, 17 de dezembro de 198।.

A pesquisa da qualidade: o projeto do Terminal de Caixa em Tempo Real da Digirede.

Revista Projeto, Desenholndustrial, número 33, setembro de $|98|$ 


\section{DESIGN NO BRASIL - HistóRIa E REALIDADE}

Data e LOCAL

Inaugurada em 12 de abril, às $19 \mathrm{~h} 30$

no Centro de Lazer SESC - Fábrica da

Pompéia

REFERENCIA ARQUIVO HISTORICO DO MASP

Caixa 17 / Pastas 98, 99 e 100

Diretor da instituicão no período

Pietro Maria Bardi

TEMA DA EXPOSIÇ̃̃O (PALAVRA-CHAVE)

design brasileiro

CurAdores ou responsávels pelo

PROJETO DA EXPOSIČ̃̃

Pietro Maria Bardi, Lina Bo Bardi, SESC e

Núcleo de Desenho Industrial - CIESP.

OBjETIVO DO EVENTO

O MASP elabora a exposição O Design

no Brasil - História e Realidade para

- SESC, por meio do convênio da

instituição com o Museu, na ocasião

da inauguração da Fábrica da Pompéia,

cujo projeto de restauro do espaço é

também de Lina Bo Bardi.A exposição

completa e soma-se a mostra organizada

no Museu anos antes, A Mão do Povo

Brasileiro. A partir do entendimento do

design enquanto produção de objetos -

artesanais e industriais - diferenciados seja pela funcionalidade, singularidade estética,

genialidade ou inventividade; a exposição reúne

novamente centenas de peças e materiais

inéditos frutos da operosidade popular como

iniciativa para a consolidação de um inventário

da cultura popular brasileira.

MATERIAL EXPOSITIVO

Objetos produzidos artesanalmente pelo povo brasileiro.

FORTUNA CRÍTICA

Mostras. Folha de S. Paulo, 30 de abril de 1982 Jundiaí vai conhecer a história do design brasileiro. Jundiaí hoje, 8 de agosto de 1982

Design: enfim, uma polêmica. Revista Senhor $\mathrm{n}^{\circ}$ 61,19 de maio de 1982, p. 62 - 64

$O$ design no Brasil, um grande momento no SESC. O Estado de S. Paulo, 17 de abril de 1982.

Um exemplo de perfeita mediação. $\bigcirc$ Estado de S. Paulo, 27 de abril de 1982.

Na velha fábrica de geladeiras, o melhor e mais avançado centro cultural do país. O Estado de $S$. Paulo, 4 de fevereiro de 1982.

Design no Brasil. ○ Estado de S. Paulo, 26 de aneiro de 1982 
DATA E LOCAL

14 a 22 de dezembro de 1982, no Museu de Arte de São Paulo (MASP)

REFERÊNCIA ARQUIVO HISTÓRICO DO MASP Caixa 4 / Pasta 19

DiRETOR DA InSTITUIÇÃo No PERÍOdO

Pietro Maria Bardi

TEMA DA EXPosiç̄̃o (PALAVRA-ChAVE) artesanato, tecelagem, Minas Gerais

CuRADORES OU RESPONSÁVEIS PELO

PROJETO DA EXPOSIÇÃO

P. M. Bardi, Lina Bo, Du Pont do Brasil S.A

apoio do Centro do Artesanato Mineiro e Comissão de Desenvolvimento do Vale Jequitinhonha - Codevale.

OBjeTIVO do EVENTO

:O evento foi parte de uma estratégia de promoção da cultura brasileira pela Du Pont do Brasil, como demonstram as palavras de Ingrid Wahle, do setor de Imprensa e Relações Públicas da empresa: "Como a experiência foi muito bemsucedida, com grande afluência de público (refere-se aqui a uma exposição dedicada (refere-se aqui a uma exposição dedicada
à cerâmica produzida no Vale do Ribeira apresentada no ano anterior) percebemos que podíamos absorver como projeto anual a tarefa de patrocinar uma mostra de arte popular, sempre com a preocupação de eleger produções ligadas às raízes culturais brasileiras. $\mathrm{E}$, principalmente, de regiões carentes, cujo trabalho é pouco divulgado e conhecido. Assim além do retorno institucional da promoção para a empresa, essas mostras levariam a essas comunidades o retorno real da venda de seus produtos e o respeito e conhecimento de seus produtos e o respeito e conhecimer
trabalhos por outros centros".

MATERIAL eXPositivo

Foram expostas 500 peças, aproximadamente, vindas de diferentes regiões de Minas Gerais, que foram executadas de modo artesanal em teares com até 300 anos de uso.

FORTUNA CRÍTICA

Requintadas obras de Arte. Revista Isto é, 22 de dezembro de 1982.

*No acervo histórico foram encontrados mais artigos, porém sem registro de fonte de origem.

Dos teares de Minas para o Museu. O Estado de São Paulo, 1982 
DATA E LOCAL

De 29 de janeiro a 14 de fevereiro de 1982

no Museu de Arte de São Paulo (MASP)

ReferênCIA ARQUIVO HISTÓRICO DO MASP

Caixa 7 / Pasta 32

DiRETOR DA InSTITUIÇÃo No PERÍOdO

Pietro Maria Bardi

TEMA da EXPosição (PALAVRA-ChAVE)

Cartaz, Japão, design gráfico.

CuRADORES OU RESPONSÁVEIS PELO

ROIETO DA

P. M. Bardi, Lina Bo, Fundação Japão,

Consulado Geral do Japão e Aliança

Cultural Brasil Japão.

OBJETIVO DO EVENTO

A exposição teve como objetivo evidenciar

A exposiça teve como o

a escola japonesa como, no Japão,

empresas e instituições públicas veem o

cartaz. Nas palavras do designer japonês

Kazumasa Nagai:"O cartaz japonês

expressa bem a história do Japão, como um

país relativamente isolado e racialmente

homogêneo, cujo povo se inclina para

responder mais fortemente aos apelos

para a sensibilidade do que para a lógica.
A tridimensionalidade da arte europeia, por exemplo, se origina na teoria lógica da perspectiva, enquanto a arte japonesa é bidimensional, buscando mais a emoção do que a profundidade da ilustração."'

Material expositivo

Foram exibidos filmes da Fundação Japão e 137 cartazes feitos por artistas japoneses.

FORTUNA CRÍTICA

A pintura de Jesus Fuertes e cartazes japoneses. Jornal da Tarde, O Estado de S. Paulo, quintafeira, 28 de janeiro de 1982

A japonesa arte de valorizar o cartaz. Diário do Grande ABC, domingo, 7 de fevereiro de 1982

No Masp, uma panorâmica da arte do cartaz japonês. Folha de S. Paulo, 3 de fevereiro de 1982

Cartaz Japonês. Folha de S. Paulo, domingo, 7 de fevereiro de 1982

BARDI, Pietro Maria. $O$ "pôster" japonês contemporâneo. Revista Senhor, número 52 II de fevereiro de 1982.

I. BARDI, Pietro Maria. O "pôster" japonés contemporâneo. Revista Senhor, número 52, 11 de fevereiro de 1982. 


\section{Criando Papéls do artista Otavio Roth}

TítULO DA EXPOSIÇÃO

DATA E LOCAL

De 28 de julho a 8 de agosto, no Museu de

Arte de São Paulo (MASP)

REFERÊNCIA ARQUIVO HISTÓRICO DO MASP

Caixa 8 /Pasta 40

DIRETOR DA INSTITUIÇÃO NO PERÍODO

Pietro Maria Bardi

TEMA DA EXPOSIÇÃo (PALAVRA-CHAVE)

papel, artesanato, arte

CURADORES OU RESPONSÁVEIS PELO

PROJETO DA EXPOSIÇÃO

P. M. Bardi, Lina Bo, Cia. Suzano de Papel Celulose.

OBJETIVO DO EVENTO

Otávio Roth, artista multidisciplinar

dedicava-se à pesquisa sobre a fabricação

de papéis e é quem funda no Brasil a

primeira fábrica de papéis artesanais.

A partir da consideração do processo

de fabricação do papel como arte, a

exposição teve como objetivo apresentar

o processo de execução dos papéis por

meio de painéis e também um conjun

extensivo de sua obra, representado por

aproximadamente trinta quadros com

folhas de cada tipo. Essa inciativa, patrocinada pela Cia. Suzano de Papel e Celulose, foi

motivada pela valorização da produção do

papel enquanto processo artístico e artesanal.

Material eXPositivo

Painéis dedicados à exposição do processo

produtivo e quadros com diversos exemplares

de tipos de papéis fabricados por Roth.

FORTUNA CRÍTICA

ONU expõe xilos do brasileiro Roth. Folha de S.

Paulo, I0 de dezembro de 198I.

Mostras de colagem e humor, as novidades. Folh de S. Paulo, 26 de julho de 1982.

Otávio Roth mostra gravuras em papéis artesanais, no MASP. Folha da Tarde, 27 de julho de 1982.

A arte de Roth, um criador de papéis. Jornal d Tarde, 28 de julho de 1982.

Nas mãos deste artista, a tradição milenar do papel. Folha de S. Paulo, 28 de julho de 1982

O papel como suporte e grafia nos desenhos de Otavio Roth. O Estado de S. Paulo, I de julho de 1982 
EXPOSIÇÃO DOS TRABALHOS DOS ALUNOS DA FACULDADE

de Desenho Industrial de Mauá

Título dA EXPOSIÇÃo

DATA E LOCAL

De 6 a 27 de junho de 1983 no Museu de

Arte de São Paulo (MASP)

REFERÊNCIA ARQUIVO HISTÓRICO DO MASP

Caixa 5 /Pasta 30

DiRETOR DA InSTITUIÇÃo NO PERÍOdO

Pietro Maria Bardi

TEMA dA EXPosiçã̃o (palaVra-ChaVE)

Desenho Industrial, ensino

CURADORES OU RESPONSÁVEIS PELO

PROJETO DA EXPOSIÇÃO

P. M. Bardi, Lina Bo, Faculdade de Desenho

Industrial de Mauá

OBjetIVO DO EVENTO

A produção dos alunos foi exibida com a

intenção de demostrar a contribuição da

disciplina para a concepção de produtos,

ao destacar a importância do campo,

pretendeu-se demostrar o papel do design,

sobretudo, para a competitividade dos

produtos.

Material eXPositivo

Maquetes, desenhos, perspectivas, protótipos

e objetos desenvolvidos pelos alunos da

Faculdade de Desenho Industrial de Mauá.

FORTUNA CRÍTICA

Alunos da Faculdade Mauá expõem no MASP.

Diário Popular, 7 de junho de 1983.

Mostras. Folha de S. Paulo, Ilustrada, terça-feira,

21 de junho de 1983. 


\section{Bordados da CaAtinga do Piauí}

Título dA EXPOSIÇÃO

DATA E LOCAL

De 9 a 8 de dezembro de 1983, no Museu

de Arte de São Paulo (MASP)

REFERÊNCIA ARQUIVO HISTÓRICO DO MASP

Caixa I /Pasta I

DiRETOR DA INSTITUIÇÃO NO PERÍODO

Pietro Maria Bardi

Tema da exposição (palavra-chave)

Bordados do Piauí

CuRAdores ou RESPONSÁVEIS PELO

PROJETO DA EXPOSIÇÃO

P. M. Bardi, patrocinado pela Du Pont do

Brasil, Fundação Ruralista do Piauí.

OBJETIVO DO EVENTO

A exposição no Museu, realizada pela

Du Pont entre várias inciativas da empresa

conjuntamente com o MASP no incentivo

à difusão da arte brasileira, reuniu três mil

peças bordadas na região de São Raimundo

Nonato no sertão do Piauí. As peças

expostas na mostra puderam ser adquiridas

durante a exposição com a renda revertida

em benefício dos próprios produtores

locais. A mostra, entre muitas outras

promovidas no Museu, reforça

o interesse da instituição em valorizar

a arte popular brasileira.
MATERIAL EXPOSITIVO

Trabalhos de bordado colorido em linho e cânhamo feitos por meninas de 7 a 14 anos.

FORTUNA CRÍTICA

Redescoberta e homenagem. Isto é, I4 de

dezembro de 1982.

A vida nossa de cada dia. Brasil, olhai os lírios das caatingas! Follha da Tarde, 12 de dezembro de 1983.

Os bordados da caatinga no MASP. Diário Popular, 9 de dezembro de 1983.

Bordado piauiense em mostra no Masp. Follha de S. Paulo, 8 de dezembro de 1983.

Um grande foco sobre o Brasil. O Estado de S.

Paulo, 5 de dezembro de 1983. 
DATA E LOCAL

De 29 de setembro a 16 de outubro de 1983 no Museu de Arte de São Paulo (MASP)

REFERÊNCIA ARQUIVO HISTÓRICO DO MASP Caixa II / Pasta 65

DiRETOR DA INSTITUIÇÃo NO PERÍODO

Pietro Maria Bardi

TEMA DA EXPOSIÇÃO (PALAVRA-CHAVE) Aloísio Magalhães

CuRADORES OU RESPONSÁVEIS PELO

PROJETO DA EXPOSIÇÃO

P. M. Bardi, Departamento de Tecnologia (Detec) da FIESP-CIESP (através do Núcleo de Desenho Industrial) e Banco Boavista.

OBjetivo do EVENTO

A exposição exibida no Museu, fora originalmente realizada por ocasião da inauguração de uma nova agência do Banco Boavista no Rio de Janeiro, em maio de 1983. A obra de Aloísio Magalhães,

como designer, artista e planejador

cultural, representou a materialização da inventividade brasileira, presente em seu trabalho como designer.A exposição teve como objetivo, não uma análise aprofundada da obra de Aloísio, mas mostrar à população que muitos dos elementos visuais participam de seu cotidiano e são frutos da relação do homem brasileiro seu ambiente material.

MATERIAL EXPOSITIVO

62 painéis justapostos dois a dois.

FORTUNA CRÍTICA

Notícias do Masp. Jornal cidade de Rio Claro, Cultura, 2 de outubro de 1983

Aloísio Magalhães: quando o design vai até o museu. $O$ Estado de S. Paulo, 30 de setembro de 1983.

Duas exposições no Masp. Folha da Tarde, 30 de setembro de 1983.

Na retrospectiva de Aloísio Magalhães um mundo de invenções visuais. Jornal do Brasil, 30 de setembro de 1983.

No Masp, a obra de Aloísio Magalhães. Folha de S. Paulo, 30 de setembro de 1983.

No lugar da rotina, grande eventos. O Estado de S. Paulo, 26 de setembro de 1983

Masp expõe desenhos industriais de Aloísio

Magalhães. Ipesi, outubro/novembro de 1983.

O deflagrador do design. Revista Isto é, I 5 de junho de 1983 


\section{CARTAZES HISTÓRICOS DA}

COMUNIDADE EUROPEIA

TíTULO DA EXPOSIÇÃO

DATA E LOCAL

De 17 de agosto a II de setembro de 1983

no Museu de Arte de São Paulo (MASP).

ReFERÊnCIA ARQUIVO HISTÓRICO DO MASP

Caixa 7 / Pasta 40

DiRETOR DA INSTITUIÇÃo NO PERÍODO

Pietro Maria Bardi

TEMA DA EXPOSIÇão (PALAVRA-ChAVE)

Cartazes, design gráfico, comunidade europeia

Curadores ou responsávels pelo

PROJETO DA EXPOSIIÇÃO

P. M. Bardi, Lina Bo, Consulado Gera

da Grécia em São Paulo (em nome

da Comunidade Europeia) e demais

Consulados dos países membros.

OBjetivo do EVENTO

Por meio de cartazes elaborados de 1945 à

data da exposição, a exposição teve como

objetivo a familiarização do Brasil com

os objetivos que regiam a formação da

Comunidade Europeia.

MATERIAL EXPOSITIVO

cartazes elaborados por artistas europeus a

partir de 1945

FORTUNA CRÍTICA

Notícias do MASP. Cidade de Rio Claro, 21 de agosto de 1983.

Masp offers wide range of exhibits. Brazil Herald Rio de Janeiro/São Paulo, 2I/22 de agosto de 1983.

Exposições. O Estado de S. Paulo, 17 de agosto de 1983.

Acontece. Folha de S. Paulo, 23 de agosto de 1983 


\section{Cristais da TChecoslováQUia}

TítuLo DA EXPOSIÇÃO

DATA E LOCAL

De 8 de fevereiro a 6 de março 1983 no Museu de Arte de São Paulo (MASP)

REFERÊNCIA ARQUIVO HISTÓRICO DO MASP Caixa II /Pasta 6 I

DiRETOR DA INSTITUIÇÃO NO PERÍODO

Pietro Maria Bardi

TEMA DA EXPOSIÇÃo (PALAVRA-CHAVE)

Cristais, arte, artesanato, vidro

CuRADORES OU RESPONSÁVEIS PELO

P. M. Bardi, Lina Bo, Dr.Václav Malosik

(Embaixador da Republica Socialista da Tchecoslovaquia).

OBJETIVO DO EVENTO

Foram exibidos o trabalho de mais de

50 oficinas, representados por 110 peças

executadas pelo Centro de Artesanato

Artístico de Skrdlovice, cidade tcheca,

com o objetivo de demonstrar o valor e o

sentimento estético do artesanato de vidro.

Material eXPositivo

110 obras de artistas do Centro de

Artesanato Artístico da Tchecoslováquia.
FORTUNA CRÍTICA

Masp exibe cristais. Folha de S. Paulo, 8 de

fevereiro de 1983.

Cristais da Tchecoslováquia. Diário Popular, 8 de fevereiro de 1983.

Exposições. Gazeta do Itaim, I I de fevereiro de 1983.

Exposições. Gazeta Pinheiros, II de fevereiro de 1983.

Museus. Folha de São Paulo, 6 de março de 1983.

Mostras. Folha de S. Paulo, 15 de março de 1983 
ITÁLIA, UM PAÍS MODELADO PELO HOMEM (MULTIVISÃO)

Título da exposição

DATA E LOCAL

De 28 de setembro a 12 de outubro de 1983 no Museu de Arte de São Paulo (MASP)

REFERENCIA ARQUIVO HISTORICO DO MASP Caixa 14 / Pasta 77

Derído

Pietro Maria Bardi

TEMA DA EXPOSIÇAO (PALAVRA-CHAVE)

Itália, Imagem do País

Curadores ou responsávels pelo

Projeto Da eXposicão

P. M. Bardi, Lina Bo, Fondazione Giovann Agnelli, Alitalia e Fiat do Brasil.

OBJETIVO DO EVENTO

A partir de pesquisa encomendada pela A pandac̃o Agnelli à Univesida por por meio da qual se pretendia conhecer a visão norte-americana sobre a Itália, a Fundação decidiu empreender um

amplo programa de promoção para a

construção de uma nova imagem do pais

no contexto internacio pis

de antes, um país associado à máfia,

massas e Michelangelo, a mostra pretendi

apresentar uma Itália que, àquela época. ocupava a sétima posição como potência industrial, resultado da criatividade de milhares de pequenos artesãos e pequenas indústrias que uniam arte e tecnologia.

MATERIAL EXPOSITIVO

Imagens exibidas por 20 projetores

superpostos e sincronizados por

computadores, fotografias e vídeos.

FORTUNA CRITICA

Imagens da arte e da indústria. Isto é, Exposição,

2 de outubro de 1983.

Entre senhores. Revista Senhor, número 133, 5

de outubro de 1983.

Itália de todos os mundos. Revista Senhor,

número I33, 5 de outubro de I983, por P.M.

Bardi.

O superintendente do Grupo Fiat fala da mostra da Fundação Agnelli. Jornal de Higienópolis, ano I, número 20.

Al Masp - il capolavoro degli italiani. La Settimana, 6 de outubro de 1983

Divirta-se. Fotografia/Crítica. Jornal da Tarde, 7 de outubro de 1983.

Italian Art and Technology, German Expressionism featured at Masp. 9/I 0 de outubro de 1983, vol. 38, número 1099 
Uma síntese inédita da Itália. Folha de S.

Paulo, llustrada, 30 de setembro de 1983.

Além da arte e da moda, as outras faces da Itália. O Globo, 4 de outubro de 1983.

POrcelana e CerÂMicA CHINESA CONTEMPORÂNEA

Notícias do Masp. Jornal da cidade de Rio

Claro, domingo, 2 de outubro de 1983

Itália, arte e tecnologia. Jornal da Tarde, 29 de

setembro de 1983.

Arte e técnica do gênio italiano. Folha de

S. Paulo, llustrada, quarta-feira, 28 de

setembro de 1983.

A Itália procura seus descendentes. $O$ Estado

de São Paulo, 28 de setembro de 1983.

Un ritratto dell'Italia in mostra a Washington.

-a settimana del Fafulla, II de novembro

de 1981.

TITULO DA EXPOSIÇÃO

DATA E LOCAL

De 14 a 25 de setembro de 1983 no Museu

de Arte de São Paulo (MASP)

REFERÊNCIA ARQUIVO HISTÓRICO DO MASP

Caixa II /Pasta 60

DiRETOR DA INSTITUIÇ̃̃o NO PERÍODO

Pietro Maria Bardi

TEMA dA EXPosição (PALAVRA-CHAVE)

Porcelana, arte, artesanato, cerâmica, China

CURADORES OU RESPONSÁVEIS PELO

PROJETO DA EXPOSICÃO

P. M. Bardi, Lina Bo, Embaixada da República

Popular da China, Banco Itaú.

OBjetIVO do EVENTO

Por meio da exposição de 93 peças, entre

vasos, potes, jarros, pratos e jogos de

chá; a exposição se propõe oferecer uma

visão geral da produção artesanal chinesa,

considerando a extensa tradição do País, de mais de 4.000 anos, no ofício da cerâmica.

MATERIAL EXPOSITIVO

cerâmica chinesa.
FORTUNA CRITICA

Exposições. O Estado de São Paulo, 15 de

setembro de 1983.

Lazer. Gazeta de Pinheiros, I6 de setembro de 1983.

Mostras. Folha de S. Paulo, 20 de setembro de 1983.

Porcelana e Cerâmica chinesa, até 25 de setembro no MASP. La Settimana, 2I de setembro de 1983. 


\section{Artesanato em COURO}

TítULO DA EXPOSIÇÃo

DATA E LOCAL

Em fevereiro de 1984, no Museu de Arte de São Paulo (MASP)

REFERÊNCIA ARQUIVO HISTÓRICO DO MASP

Caixa I4/Pasta 63

DiRETOR DA INSTITUIÇÃO NO PERÍODO

Pietro Maria Bardi

MATERIAL EXPOSITIVO

Trabalhos de gravação em couro.

TEMA DA EXPOSIÇÃO (PALAVRA-CHAVE)

Artesanato, couro

CuRADORES OU RESPONSÁVEIS PELO

PROIETO DA EXPOSICÃO

P. M. Bardi, Lina Bo, Fundação Associação

Orientadora de Artesanato do Japão.

\section{OBjetivo do EVEnTO}

A exposição apresentou trabalhos de

gravação em couro executados por

contribuiu para a popularização da arte de

gravação no Brasil, com a difusão do estilo

pirografado.

FORTUNA CRÍTICA

Artesanato em couro, no Masp. O Estado de S.

Paulo, sem data. 


\section{Projeto Feito em Casa}

\section{(Exposições: Bonecos de Pano, Artesanato em}

Madeira, Jolas Artesanals, EXPosiç̃ão BatiK)

DATA E LOCAL

EXPOSIÇÃo BATIK inaugurada em 18 de abril

de 1984 no Museu de Arte de São Paulo

(MASP)

EXPOSIÇÃo Bonecos de Pano de $1^{\circ}$ de junho a 15 de julho de 1984, no Museu de Arte de São Paulo (MASP).

EXPosição JoIAs ARTESANAIS de 19 de julho a

19 de agosto de 1984 no Museu de Arte de

São Paulo (MASP).

Exposição Artesanato em Madeira de 12

de setembro a 14 de outubro de 1984 no

Museu de Arte de São Paulo (MASP).

REFERÊNCIA ARQUIVO HISTÓRICO DO MASP

Caixa 12 /Pasta 52

DIRETOR DA INSTITUIÇÃO NO PERÍODO

Pietro Maria Bardi

TeMA DA EXPOSIÇÃo (PALAVRA-ChAVE)

Artesanato

CuRADORES OU RESPONSÁVEIS PELO

PROJETO DA EXPOSIIÇÃO

P. M. Bardi, Lina Bo Bardi, Prefeitura de S.

Paulo (programa Feito-em-casa).

OBJETIVO DO EVENTO

As exposições são parte do programa "Feito

em Casa", organizada pela Secretaria Municipa de Planejamento, SEMPLA, com o objetivo de atender a desempregados e aos pequenos $\mathrm{e}$ inúmeros produtores domésticos de São Paulo, numa tentativa de ajudá-los a viver das suas próprias criações.

Material expositivo

Objetos Artesanais.

FORTUNA CRITICA

LEITE, Mônica Ximenes. Mais visível. Revista Senhor, número 175, 25 de julho de 1984.

Anote na agenda. Jornal da Tarde, 10 de

novembro de 1984.

Muitos brinquedos artesanais no MASP. Jornal da Tarde, I I de dezembro de 1984. 
TRANÇADO BRASILEIRO

Título da EXPOSIÇão

DATA E LOCAL

De 16 de outubro a 27 de outubro de

1985, no Museu de Arte de São Paulo

(MASP).

REFERÊNCIA ARQUIVO HISTÓRICO DO MASP

Caixa $5 /$ Pasta 38

Dinstituicão no período

Pietro Maria Bardi

TEMA DA EXPOSIÇAO (PALAVRA-CHAVE)

Trançado brasileiro

\section{CuRADORES OU RESPONSÁVEIS PELO}

ProjeTO Da EXPOSICão

P. M. Bardi, Lina Bo, Jacob Klintowitz, Paulo Figueiredo, Alice Lunardelli , apoio Rhodia S/A e Secretaria de Estado da Cultura.

OBjETIVO DO EVENTO

A exposição promovida pela Rhodia foi

uma iniciativa, entre tantas outras, para a

valorização e preservação da arte popular

brasileira. A mostra foi dividida em 4 partes:

o primeiro com cestas, esteiras, redes e

peneiras de índios do Amazonas, Pará,

Maranhão e Mato Grosso; no segundo,

trabalhos dos estados do Nordeste; no

terceiro, produções de Minas Gerais, Goiás e interior de São Paulo e no quarto, criações litorâneas do Centro-Sul e Espírito Santo, Rio de Janeiro, São Paulo, Paraná, Santa Catarina e Rio Grande do Sul; incluindo as obras dos índios guaranis.

Material expositivo

Cestas, esteiras, peneiras, redes e outros trabalhos de artesanato das mais diversas origens no País.

Fortuna CRÍTICA

Pré-Estréia. O Estado de S. Paulo, 14 de outubro de 1985

Trançado Brasileiro. Jornal da Tarde, 16 de outubro de 1985. 
DATA E LOCAL

De 23 de agosto a $1^{\circ}$ de setembro de 1985

no Museu de Arte de São Paulo (MASP)

REFERÊNCIA ARQUIVO HISTÓRICO DO MASP

Caixa 5 / Pasta 4l

DiRETOR DA INSTITUIÇÃO NO PERÍODO

Pietro Maria Bardi

TeMa da EXPosição (PALAVRA-ChAVE)

artes gráficas, tipografia

CurAdores ou responsáVEIS PELO

PROJETO DA EXPOSICÃO

P. M. Bardi, Lina Bo, patrocínio de J.Walter

Thompson, Pancron e Repro.

OBJETIVO DO EVENTO

O Type Directors Club nasce na década

de 1940 em Nova lorque, formado por

designers gráficos, cujo objetivo é a

promoção da excelência da tipografia por

meio de reuniões, palestras e exposições.

A exposição, exibida em São Paulo e

posteriormente no Museu de Arte

Moderna do Rio de Janeiro (MAM RJ), foi

formada por trabalhos selecionados com o

objetivo de apresentar uma coleção de alta

representatividade das tendências nas artes

gráficas em todo o mundo.
TERIAL EXPOSITIVO

200 dos melhores trabalhos de artistas de

todo o mundo no campo gráfico, selecionados por um júri de personalidades.

FORTUNA CRÍTICA

Que bom tipos o tragam! Arte Afinal, setembro de 1985.

Os melhores artistas gráficos do mundo no Masp. Folha da Tarde, 22 de agosto de 1985. 


\section{VidRos de Murano}

Título da EXPOSIÇÃO

DATA E LOCAL

De 5 a 21 de dezembro de 1986 no Museu

de Arte de São Paulo (MASP)

RefERÊNCIA ARQUIVO HISTÓRICO dO MASP

Caixa $10 /$ Pasta 60

DiRETOR DA INSTITUIÇÃo NO PERÍODO

Pietro Maria Bardi

TEMA DA EXPOSIÇÃo (PALAVRA-CHAVE)

arte, artesanato, vidro

CuRADORES OU RESPONSÁVEIS PELO

ROIETO DA EXPOSICÃO

P. M. Bardi, Lina Bo, Eduardo Antonio da

Silva Prado, Instituto Italiano de Cultura,

Instituto Cultural Ítalo-brasileiro, patrocínio

pela Regione Veneto.

OBjETIVO DO EVENTO

A mostra exibiu peças de vidro de Murano,

Itália, executadas à mão, a fim de apresentar

o processo produtivo destas e as relações

entre a tradição e o design contemporâneo.
Material expositivo

130 peças feitas a mão, segundo antigas

técnicas da arte do vidro. Firmas representadas

são: Barovier Toso, Carlo Moretti, Ongaro,

Alfredo Barbini, Pietro Ragazzi,Vetreria F.,

Vincenzo Nason, Salviati, Formia.

FORTUNA CRÍTICA

Sexta. Folha de S. Paulo, $1^{\circ}$ de dezembro de

1986.

La "sereníssima" arte di Murano. || Corriere, I5

de dezembro de 1986. 
Arte do Povo Brasileiro Coleção jacques Van de Beuque

Título dA EXPOSIÇÃo

DATA E LOCAL

De 9 a 27 de abril de 1986, no Museu de Arte de São Paulo (MASP)

REFERÊNCIA ARQUIVO HISTÓRICO DO MASP Caixa 7 /Pasta 43

DiRETOR DA INSTITUIÇÃo NO PERÍODO

Pietro Maria Bardi

Tema da EXPosição (PalAVRA-CHAVE)

Arte do Povo Brasileiro

CuRADORES OU RESPONSÁVEIS PELO

PROJETO DA

P. M. Bardi, Lina Bo Bardi

Coleção Jacques Van de Beuque.

OBJETIVO DO EVENTO

A mostra, dedicada a exibir a coleção

de Jacques Van de Beuque, é mais uma

expresão do pioneirismo da instiuça

expressão do pioneirismo da instituição

em valorizar a cultura popular brasileira. $A$

exposição de parte deste acervo foi antes

apresentada no Museu de Arte Moderna

do Rio de Janeiro (MAM RJ), em I976, e

pela Fundação Roberto Marinho no Rio de

Janeiro em 1983. Van de Beuque, francês,

iniciou sua coleção de arte popular nos

anos 1950, quando, numa de suas viagens

a Recife, conheceu o mestre Vitalino, cuja

obra fora exibida no MASP, em 1949, na

primeira exposição dedicada à arte popular

nordestina.
MATERIAL EXPOSITIVO

250 peças de artesanato nordestino da coleção Jacques Van de Beuque.

FORTUNA CRÍTICA

A mão do povo. Veja, I I de agosto de 1976. Dois mil metros de arte popular. Revista Afinal, 22 de abril de 1986

BARDI, Pietro Maria. Sem a ajuda dos críticos. Revista Senhor n² 266, 22 de abril de 1986. Mostra permanente, francês expõe no Rio arte de todo o Brasil. Revista Interior $n^{\circ} 54$, janeiro/ fevereiro de 1984

Um artista do povo. Manchete $\mathrm{n}^{\circ} 1.634,13$ de agosto de 1983

Arte do povo, no Rio, o melhor do artesanato nordestino. O Globo, 2I de julho de 1983.

Hora e vez da arte popular: carrancas, cerâmicas, ex-votos. O Globo, 4 de julho de 1976.

Casa do Bispo mostra a arte do povo do Nordeste. O Globo, 22 de julho de 1983.

Amor antigo à cultura do Brasil. Jornal de Brasília, 10 de outubro de 1984

Museus e galerias, em animada concorrência. O Estado de S. Paulo, 10 de abril de 1986. Lá vem a arte do povo brasileiro. $O$ Estado de $S$. Paulo, 8 de abril de 1986. 
ROUPAS BORDADAS DE

Glaucia Amaral de Souza

Título DA EXPOSIÇÃo

DATA E LOCAL

5 a 17 de agosto de 1986, no Museu de Arte de São Paulo (MASP)

REFERÊNCIA ARQUIVO HISTÓRICO DO MASP Caixa 09/ Pasta 52

DIRETOR DA INSTITUIÇÃO NO PERÍODO

Pietro Maria Bardi

TEMA DA EXPosição (PALAVRA-CHAVE)

Roupas bordadas

CuRADores OU RESPONSÁVEIS

PELO PROJETO DA EXPOSIÇÃO

Pietro Maria Bardi, Lina Bo Bardi,

OBJETIVO DO EVENTO

Como um reflexo do movimento norteamericano de wearable art, iniciado nos anos 1960, no qual artistas rediscutiram anos 1960, no qual artistas rediscutiram ao adotar a roupa com suporte, Glaucia Amaral de Souza, socióloga e artesã,

apresenta a exposição Roupas Bordadas, em continuidade à discussão das relações entre arte e moda.
MATERIAL EXPOSITIVO

No total de 21 peças, a maioria delas em

algodão ou de tecidos feitos à mão em

Minas Gerais e no Nordeste.As roupas

apresentavam desenhos abstratos, com figuras

geométricas ou bichos de forma estilizada, com

a valorização das cores e dos traçados dos

bordados.

FORTUNA CRÍTICA

Roupas no Masp. Folha de S. Paulo, 2 de julho de 1986.

Arte em bordado. $O$ Estado de S. Paulo, quintafeira, 3 I de julho de 1986.

Obras de arte em forma de roupa. Revista Afinal, 5 de agosto de 1986.

Esta exposição do Masp recupera a tradição do bordado. Revista Claudia, agosto de 1986. 


\section{Cartazes "Obras-primas}

DO CINEMA FRANCÊS"

Título dA EXPOSIÇÃo

DATA E LOCAL

De 27 de agosto a 14 de setembro de 1986

no Museu de Arte de São Paulo (MASP)

REFERÊNCIA ARQUIVO HISTÓRICO DO MASP

Caixa 5 / Pasta 28

DiRETOR DA INSTITUIÇÃo NO PERÍOdo

Pietro Maria Bardi

TEMA DA EXPOSIÇão (PALAVRA-ChAVE)

cartaz, design gráfico, cinema, França

CurAdores ou responsávels pelo

PROJETO DA EXPOSIÇÃO

P. M. Bardi, Lina Bo, patrocinada pela Air

France, Consulado Geral da França em São

Paulo e Banco Frances e Brasileiro S.A.

OBJETIVO DO EVENTO

Em homenagem aos 90 anos do cinema, a

Air France traz ao Brasil uma exposição

de 130 cartazes cinematográficos

de 130 cartazes cinematográficos

XIX à contemporaneidade. Exposição,

primeiramente exibida no Paço Imperial no

Rio de Janeiro, é aberta no Museu em 27

de agosto de 1986

MATERIAL EXPOSITIVO

Aproximadamente 130 cartazes originais

executados por vários artistas gráficos

europeus desde $\circ$ final do XIX a meses antes

da abertura da exposição.

FORTUNA CRÍTICA Quando o cinema provoca outra arte. Domingo, suplemento Jornal do Brasil, 27 de setembro de 198

O Rio comemora os 90 anos do cartaz de cinema. Folha de S. Paulo, $I^{\circ}$ de agosto de 1986.

Renovando antigas emoções, cartazes do cinema francês. Jornal do Brasil, 6 de agosto de 1986 . A moda agora é o básico. Jornal do Brasil, sábado, 16 de agosto de 1986.

Cartazes antigos do cinema francês. Folha de S. Paulo, 2 de setembro de 1986. 


\section{Retrospectiva do Relógio}

Título DA EXPOSIÇÃO

DATA E LOCAL

De 19 a 31 de novembro de 1986 no

Museu de Arte de São Paulo (MASP)

ReFERÊNCIA ARQUIVO HISTÓRICO DO MASP

Caixa 3 /Pasta II

DiRETOR DA InstituIÇÃO NO PERÍOdO

Pietro Maria Bardi

TEMA DA EXPosição (PALAVRA-ChAVE)

design, relógio, tecnologia

Curadores ou responsávels Pelo

PROIETO DA EXPOSICÃO

P. M. Bardi, Lina Bo, patrocínio da Indústria

de Relógios Dimas de Melo Pimenta

(DIMEP).

OBJETIVO DO EVENTO

A exposição, uma retrospectiva constituída

pela exibição de 250 relógios do Museu do

Relógio da Indústria de Relógios Dimas de

Melo Pimenta (DIMEP), pretendeu mostrar

a evolução, a história dos relógios, por meio

das peças, livros e folhetos.

Material eXPositivo

coleção de 250 relógios

FORTUNA CRÍTICA

Mostra leva ao Masp 250 relógios e um quadro de Aldemir Martins. Folha de S. Paulo, 19 de

novembro de 1986.

Dicas. Jornal da Tarde, 20 de novembro de 1986 
Máscaras Brasileiras

Título da EXPOSIÇão

DATA E LOCAL

De 2 a 19 de outubro de 1986, no Museu

de Arte de São Paulo (MASP)

REFERÊNCIA ARQUIVO HISTÓRICO DO MASP

Caixa $3 /$ Pasta 17

DiRETOR DA INSTITUIÇÃo NO PERÍODO

Pietro Maria Bardi

TEMA dA EXPosição (palaVRa-ChaVE)

Máscaras brasileiras

Curadores ou responsávels Pelo

PROJETO DA EXPOSIÇÃO

P. M. Bardi, Lina Bo, apoio da Rhodia S/A

através do Projeto Cultural Rhodia,

iniciado em 1985.

OBjetIVO do EVENTO

Máscaras Brasileiras foi tema do Projeto Cultural Rhodia do ano de 1986. Em

1985, a Rhodia iniciou uma nova fase na

editoração de seus livros, lançando a obra "Trançado Brasileiro", um projeto gráfico de Jacob Klintowitz, com fotos de Lew

Parrela, Mário Cravo Neto e Rômulo

Fialdini Esta primeira iniciativa com

Fialdini. Esta primeira iniciativa, com

a objetivo de estimular e documentar a formação de uma biblioteca de Arte Popular Brasileira, por meio do registro do trabalho de artesãos brasileiros como homenagem

àqueles que, com suas mãos, constroem peça de belíssima plasticidade e com grande função social e utilitária.

Material expositivo

Mais de cem máscaras brasileiras.

FORTUNA CRÍTICA

Festejo mascarado. Veja, I 3 de agosto de 1986. Máscaras Brasileiras. Projeto Cultural Rhodia. Catálogo da exposição, Museu de Arte de São Paulo, I986.

História, arte e fascínio, nas máscaras brasileiras. Jornal da Tarde, 29 de setembro de 1986. 


\section{Le Corbusier e o Brasil}

TíTULO DA EXPOSIÇÃO

DATA E LOCAL

6 de outubro de 1987, no Museu de Arte de São Paulo (MASP) em simultâneo a uma exposição equivalente, no Centro George Pompidou de Paris.

REFERÊNCIA ARQUIVO HISTÓRICO DO MASP

Caixa 5 / Pasta 28

Diretor da instituiç̃̃o no PERÍODO

Pietro Maria Bardi

TEMA DA EXPOSIÇÃO (PALAVRA-CHAVE)

arquitetura moderna, Le Corbusier

Curadores ou responsávels pelo

RROIETO DA EXPOSICÃO

P. M. Bardi, Lina Bo, a Associação Brasileira

de Ensino de Arquitetura, a Hunter Douglas

e os governos francês e brasileiro.

OBJETIVO DO EVENTO

Em homenagem ao centenário de

nascimento do arquiteto francês, a

exposição no Museu pretendeu mostra

no País a produção de Le Corbusier em

diversos campos. Ocorre simultaneamente

a inúmeros eventos realizados também no

Brasil e em todo o mundo em torno do

tema. Paralela à exposição, é inaugurada em

3 de setembro do mesmo ano, uma exposição de mobiliários de autoria de Corbusier,

reproduzidos pela empresa italiana Cassina, na loja Forma, na avenida Faria Lima, São Paulo.

MATERIAL EXPOSITIVO

Mais de 400 documentos e objetos, entre

fotos, textos, croquis, maquetes, telas,

tapeçarias pertencentes à Fundação $L$

Corbusier

FORTUNA CRITICA

Expô de esboços de Le Corbusier. O Globo,

sexta-feira, 20 de fevereiro de 1987

Um gênio faz 100 anos. Hora H, quarta-feira, 25

de fevereiro de 1987

Le Corbusier, arquiteto erótico. $\bigcirc$ Globo, 22 de abril de 1987.

Le Corbusier, o arquiteto do século. Jornal do

Brasil, 27 de abril de 1987.

O Brasil construído por Le Corbusier. Folha de S.

Paulo, 3 de julho de 1987.

Le Corbusier e o Brasil, juntos pelo mundo.

Estado de S. Paulo, Jornal da Tarde, I 3 de

agosto de 1987. 
O Criador da casa moderna. O Globo, , 6 de setembro de 1987.

100 anos de Le Corbusier. O Globo, 10 de

setembro de 1987

0 arquiteto do mundo novo. Jornal do Brasil, 6 de outubro de 1987.

Corbusier criticado. $O$ Globo, 14 de outubro de 1987.

O povo não frequenta os pilotis. Jornal do Brasil, 17 de outubro de 1987.

BARDI, Pietro Maria. Cem anos, com

exclamação. Revista Senhor, I3 de outubro de 1987
DATA E LOC

7 a 26 de julho de 1987, no Museu de Arte de São Paulo (MASP)

REFERÊNCIA ARQUIVO HISTORICO DO MASP

1987 - Caixa 2.I/ Pasta 8

DERTIÓDO

Pietro Maria Bard

TEMA DA EXPOSIIÇ̃̃o (PALAVRA-CHAVE)

$\bmod$

CURADORES OU RESPONSÁVEIS

EELO PROJETO DA EXPOSIČ̃̃

Pietro Maria Bardi, Lina

Bo Bardi, com o apoio da Paradoxart.

OBJETIVO DO EVENTO

A exposição tem como objetivo retomar discussão das relações entre arte e moda de modo semelhante à proposta realizada ainda em 195I, com a realização do desfile ainda em I95I, com a realização do desfile de costumes antigos e da coleção do estilista francês Christian Dior. Em parceria com a Paradoxart que, na época, divulgava e comercializava a wearable art, movimento iniciado ainda nos anos 1960 nos Estados Unidos, no qual um grupo de artistas redis-
cutiu o limiar do espaço estético e do corpo cutiu o limiar do espaço estético e do corpo, se sentiriam nos anos 1980 no Brasil.
Trajes de Fernando Marques Penteado, Liana Boisi, Glaucia Amaral de Souza produzidos pela Paradoxart, ao lado de trabalhos de Andrea Kraemer, Maria Tereza Castor, Orieta del Sole, Rolando Rasmussen. Sete peças cedidas pelo Museu Histórico do Rio de Janeiro, peças de artistas plásticos, entre eles: Bonadei, Aldemir Martins, Lina Bo Bardi, Salvador Dali e peças de artistas emprestadas pela Julie's Artisians Gallery, de Nova lorque.

FORTUNA CRÍTICA

Como arte no corpo. Revista Afinal, 21 de julho de 198

Fora da moda. Revista Visão, I5 de julho de 1987. BARDI, Pietro Maria. Arte para ver e usar. In Revista Senhor n 330 , I 4 de julho de 1987.

Traje também é arte. $O$ Estado de S. Paulo, 7 de julho de 1987.

Masp abre exposição sobre $a$ arte da roupa. Folha de S. Paulo, terça-feira, 7 de julho de 1987.

Visuais - A roupa como manifestação artística. $\mathrm{O}$ Estado de S. Paulo, 6 de julho de 1987.

Wearable, $a$ arte impressa em roupas. $O$ Estado de S. Paulo, 2 de julho de 1987. 


\section{SAO - Divisão de Design dA DPZ}

Título dA EXPOSIÇÃo

DATA E LOCAL

De 10 de março a 29 de março de 1987 no

Museu de Arte de São Paulo (MASP)

REFERÊNCIA ARQUIVO HISTÓRICO DO MASP

Caixa 7 / Pasta 40

DIRETOR DA INSTITUIÇÃO NO PERÍODO

Pietro Maria Bardi

TEMA DA EXPOSIIÇÃO (PALAVRA-CHAVE)

SAO, DPZ, design gráfico

Curadores ou responsávels pelo

PROJETO DA EXPOSIÇÃO

P. M. Bardi, DPZ.

DBJETIVO DO EVENTO

A SAO, divisão de design da agência

de publicidade DPZ, tem sua produção

exposta no Museu não somente como uma

oportunidade de mostrar o trabalho dos

seus designers ao público, mas como um

momento oportuno para a análise crítica

sobre sua produção bem como para a

promoção do design junto aos diversos

segmentos da sociedade.

Material EXPOSITIVO

Projetos visuais desenvolvidos para inúmeras empresas.

FORTUNA CRÍTICA

Logotipos de cigarros, bancos e companhias aéreas da DPZ no Masp. Revista Visão, Il de março de 1987

Os símbolos da nossa época. Jornal do Brasil, Rio de Janeiro, 9 de março de 1987. 


\section{A ARTE DO AUTOMÓVEL}

DATA E LOCAL

De 28 de julho a 16 de agosto de 1987 no

Museu de Arte de São Paulo (MASP)

REFERÊNCIA ARQUIVO HISTÓRICO DO MASP

Caixa 8 / Pasta 45

DiREtor DA Instituição no PERÍOdo

Pietro Maria Bardi

TEMA DA EXPOSIÇÃO (PALAVRA-CHAVE)

automóvel, tecnologia, design, indústria, arte

CuRADORES OU RESPONSÁVEIS PELO

PROJETO DA EXPOSIÇÃO

P. M. Bardi, Lina Bo, e Glasurit do Brasil.

OBjetIVO DO EVENTO

Por meio da intervenção de diversos

artistas convidados a pintar carrocerias

de automóveis pretendia-se sensibilizar

o público acerca das relações entre arte-

indústria. Com isso compreendia-se que

- design de produtos industriais cada vez mais ganhava espaço como representação

de arte.
Material expositivo

Carrocerias de carros pintadas ou organizadas de forma a se tornar interpretações de obras de Alexander Calder, Tarsila do Amaral, Paul Klee, Vasareli, Maria Helena Chartuny, Rivaldo Catende e José Joaquim Lunazzi.

FORTUNA CRÍTICA

Automóvel e Arte. Capôs, tetos, portas, pintados sob inspiração de mestres. Jornal da Tarde, 28 de julho de 1987.

Belas pinturas. A tela: capôs e latarias. Jornal da Tarde, quarta-feira, 29 de julho de 1987.

Museu de São Paulo expõe arte moderna no automóvel. Folha de S. Paulo, domingo, 2 de agosto de 1987

A arte no automóvel. $\bigcirc$ Globo, Rio de Janeiro, quinta-feira, 6 de agosto de 1987.

Os vínculos da arte com a ciência e a história. A tribuna, 8 de agosto de 1987.

Um novo veículo. Revista Visão, 5 de agosto de 1987. 


\section{EPOPÉIA EDITORIAL: UMA HISTÓRIA DA INFORMAÇÃO E CULTURA \\ Título dA EXPOSIÇÃo}

DatA e LOCAL

De 3 de abril a 3 de maio de 1987 no

Museu de Arte de São Paulo (MASP)

REFERÊNCIA ARQUIVO HISTÓRICO DO MASP

Caixa 8 / Pasta 47

DIRETOR DA INSTITUIÇÃO NO PERÍODO

Pietro Maria Bardi

TEMA DA EXPOSIÇÃO (PALAVRA-CHAVE)

imprensa, informação, cultura, artes gráficas e jornalismo.

Curadores ou responsáveis pelo

PROJETO DA EXPOSICÃ̃O

P. M. Bardi, Lina Bo, CLC e Editora Abril.

OBJETIVO DO EVENTO

A exposição fez parte das comemorações

dos quarenta anos do Museu e fo

promovida conjuntamente com a editora

Abril, à época responsável pelas revistas,

Abril, à época responsável pelas revistas, e
com a Comunicações, Lazer, Cultura (CLC)

também do grupo Abril, responsável pelos

fascículos.A exposição mostra, por meio

de uma série de painéis fotográficos, 0

coniunto de publicaçães dos dois grupos

conjunto de publicaçôes dos dois grupos

com a evolução dessas publicações nos

últimos 37 anos e um painel histórico

desse período.A mostra pretendia oferecer aos leitores e ao público em geral, uma ideia da evolução do ramo editorial desde os anos da evolu.
1950.

MATERIAL EXPOSITIVO

Painéis compostos por 2500 fotos que

representam a história das empresas que
compõe os grupos CLC - Comunicações,

Lazer, Cultura e Editora Abril desde suas

origens.

FORTUNA CRÍTICA

Artes gráficas, em museu. Jornal da Tarde, 2 de fevereiro de 1987

Mostra sem segredos. Jornal do Brasil, 6 de abri de 1987

Masp inaugura a "Epopéia Editorial". Folha de S. Paulo, 2 de abril de 1987 


\section{Primeira Mostra InTernacional de Posters Ecológicos}

Título da EXPOSIÇÃO

Data e LOCAL

De 8 de junho a 19 de junho de 1988 no Museu de Arte de São Paulo (MASP)

REFERÊNCIA ARQUivo HISTÓRICO DO MASP Caixa 3 / Pasta 15

DiRETOR DA InSTITUIÇÃo NO PERÍOdo

Pietro Maria Bardi

TEMA DA EXPOSIÇ̄̃̃o (PALAVRA-CHAVE) posters, design gráfico, ecologia

Curadores ou responsávels pelo

PROJETO DA EXPOSIÇÃO

P. M. Bardi, Lina Bo,Associação In Natura

de Consciência Ecológica, da Secretaria

Municipal da Cultura, Empresas Ogilvy \&

Mather, Maison Forestier e patrocínio da

American Express Card.

Objetivo do EVENTO

Por meio da exposição de 70 pôsteres

vindos de diversos países, como Áustria,

Alemanha, Colômbia, Suíça, Filipinas, África,

EUA, Caribe e Paquistão, a mostra teve

como objetivo sensibilizar as populações

sobre a importância da preservação do

meio ambiente e de espécies animais e

vegetais ameaçadas de extinção.

Material EXPOSITIVO

Pôsteres de diferentes partes do mundo

de entidades como In Natura,WWF e

Greenpeace.

FORTUNA CRÍTICA

Inúmeros, dentre os quais:

Causa ecológica está chegando ao Masp, em posters. Diário Popular, São Paulo, 8 de junho de 1988.

Arte Ecológica no Masp. A gazeta esportiva, São Paulo, 6 de junho de 1988.

Asteriscos. Diário Popular, São Paulo, 12 de junho de 1988.

Posters ecológicos no Masp. Diário do Grande ABC, Santo André, 14 de junho de 1988.

No Masp, a I Mostra Internacional de Posters Ecológicos. O Estado de S. Paulo, 15 de junho de 988.

Na moda. O Estado de S. Paulo, 2 I de junho de 1988.

Confetes. A Gazeta Esportiva. I0 de julho de 1988

Exposição. Diário do Comércio, 10 de junho de 1988. 
CAPAs de REVISTA ITALIANA - FMR

Título dA EXPOSIÇÃo

Data e Local

Realizada em setembro de 1988, no Museu

de Arte de São Paulo (MASP)

REFERÊNCIA ARQUIVO HISTÓRICO DO MASP

Caixa 3 / Pasta 18

DiRetor DA InSTITUIÇÃO NO PERÍODO

Pietro Maria Bardi

TEMA DA EXPOSIÇ̄̃o (PALAVRA-CHAVE)

FMR, gráfica italiana.

Curadores ou responsávels pelO

PROJETO DA EXPOSIÇÃO

Pietro Maria Bardi

Material eXPositivo

63 números da revista FMR.

FORTUNA CRITIICA

A visão de marketing de um mago do

Renascimento. $\bigcirc$ Estado de S. Paulo, 9 de

setembro de 1988.

Franco Maria Ricci, grafia da sofisticação.

O Estado de S. Paulo, 9 de setembro de 1988.

Masp expõe coleção da revista italiana de arte

"FMR". Follha de S. Paulo, 2 de setembro

de 1988.

ObjeTIVO do EVEnTO

A revista FMR, iniciais de Franco Maria

Ricci, era a revista de arte mais sofisticada,

mais bem impressa e redigida em toda

a Europa.A exposição dos exemplares

doados por Ricci ao Museu fora

programada para ser aberta conjuntamente

com a Bienal do Livro. 
DATA E LOCAL

De 14 a 23 de julho de 1988, no Museu de

Arte de São Paulo (MASP)

REFERÊNCIA ARQUIVO HISTÓRICO DO MASP

Caixa 12 / Pasta 46

DiRETOR DA INSTITUIÇÃO NO PERÍODO

Pietro Maria Bardi

Tema da eXPosiç̄ão (palaVra-chaVE)

Artesanato Indígena

CurAdores ou responsávels pelO

PROJETO DA EXPOSIÇÃO

P. M.Bardi, Lina Bo, FUNA

OBJETIVO DO EVENTO

A exposição de artefatos indígenas teve

como objetivo preservar e divulgar a

arte indígena. A mostra não somente se

limitava a apresentá-los, como também er

possível na ocasião a aquisição de diversos

trabalhos, de trançado, plumária, tecelagem,

cabaça, madeira, cascas, sementes, contas

e cerâmicas, entre outras produções

artesanais ou de utilidade doméstica.
Material EXPOSitivo

Artefatos indígenas.

ForTUNA CRÍTICA

A arte indígena é tema de exposição. Diário Popular, 14 de julho de 1988.

Índios agitam o Masp com exposição quente. Notícias Populares, 14 de julho de 1988 e

Jornal da Tarde, I I de julho de 1988.

MASP e MAC inauguram mostras sobre a cultura indígena. Folha de S. Paulo, I I de julho de 1988. A arte que os índios sabem fazer. Folha da Tarde, 9 de julho de 1988.

Os índios Marúbo chegam ao Masp, com

artesanato, maloca e tudo. Jornal da Tarde, 8 de julho de 1988.

E a IX Moitará - Feira Nacional do Artesanato Indígena, a partir do dia 15. Jornal da Tarde, 8 de julho de 1988. 


\section{PRODUTO - FORMA - HISTÓRIA}

\section{I50 anos de Design Alemão}

TítULO DA EXPOSIÇÃo

DATA E LOCAL

De 18 de novembro de 1988 a 15 de

janeiro de 1989 no Museu de Arte de São

Paulo (MASP)

REFERÊNCIA ARQUIVO HISTÓRICO DO MASP

Caixa II /Pasta 40

Diretor da instituicão no período

Pietro Maria Bardi

TEMA DA EXPOSIÇÃO (PALAVRA-CHAVE)

Design alemão

Curadores ou responsávels Pelo

PROJETO DA EXPOSIÇÃO

P. M.Bardi, Lina Bo, Heinz Fuchs, François

Buckhardt, Karl George Bitterberg,

Instituto de Relações Exteriores de

Stuttgart, Escola Superior Técnica de

Stuttgart, Consulado Geral da República

Federal da Alemanha, Instituto Goethe São

Paulo.

OBJETIVO DO EVENTO

A exposição, importante retrospectiva,

teve como objetivo fornecer um resumo

(150 a propo

longo de 150 anos. A proposta tambem não consideração de produtos produzidos antes da metade do século XIX como

design. Exemplares do início do XIX à

contemporaneidade foram exibidos como

forma de mostrar a importância da atividade não somente como arte, como também

elemento importante do registro da cultura

de uma determinada época, reflexo da

multifacetada complexidade, desejos e atitudes de uma sociedade.

Material expositivo

Dividida em sete segmentos, a exposição

trouxe peças originais, algumas emprestadas

de museus ou coleções particulares e painéis

fotográficos organizados numa tentativa

de propor uma visão histórica a partir do

resgate de um conjunto de características

da produção germânica dos anos 1820 à

contemporaneidade.

FORTUNA CRÍTICA

BARDI, Pietro Maria. A influência de Bauhaus. Revista Isto é/Senhor, 30 de novembro de 988

Linha de frente. Revista Isto é/Senhor, 23 de novembro de 1988. 
novembro de 1988

Exposição no MASP apresenta a evolução do

design alemão. Diário do Grande ABC, 3 de

dezembro de 1988.

Design alemão - um marco nas artes.

A Tribuna, Santos, 26 de novembro de 1988.

Traço germânico. Revista Veja, 23 de

novembro de 1988

MASP mostra um século e meio de design

alemão. Diário do Grande ABC, 19 de

novembro de 1988

A potência do "design" decifra a sua história.

O Estado de S. Paulo, 17 de novembro de

1988.

De Biedermeier ao MagLev, as formas do

Alemanha. Jornal da Tarde, 10 de novembro

de 1988

Design alemão por Paulo Marcos del Greco.

Guia das Artes Plásticas, novembro de

1988

Designer - Ruben MARTINS

TÍtulo DA EXPOSIÇÃo

DATA E LOCAL

De 9 a 20 de agosto de 1989 no Museu de

Arte de São Paulo (MASP)

REFERÊNCIA ARQUIVO HISTÓRICO DO MASP

Caixa I /Pasta 5

DIRETOR DA INSTITUICÃo NO PERÍDDO

Pietro Maria Bardi

TeMa da EXPosição (PALAVRA-CHAVE)

Ruben Martins

CURADORES OU RESPONSÁVEIS PELO

PROJETO DA EXPOSIÇ̃̃O

Pietro Maria Bardi e Fernanda Martins.

OBJETIVO DO EVENTO

A exposição teve como objetivo apresentar

o trabalho do designer Ruben Martins,

fundamental para a consolidação do

design gráfico no País. A mostra exibiu a

produção do designer, marcas, logotipos,

embalagens e produtos por meio de 50

painéis divididos em duas partes: uma

cronológica, construindo um itinerário de

sua obra e outra, reunindo tudo o que não foi possível datar.A exposição, organizada pela filha do designer, também pretendia resultar num livro sobre a obra de Ruben Martins.

MATERIAL EXPOSITIVO

50 painéis que exibiam a produção do designer.

FORTUNA CRÍTICA

ANDERÁOS, Ricardo. Masp expõe um dos pioneiros da criação gráfica no Brasil. Folha de S. Paulo, 7 de agosto de 1989. 


\section{Mostra do Produto Brasileiro: \\ DESIGN E TECNOLOGIA}

Título dA EXPOSIÇÃo

DATA E LOCA

De 01 a 15 de dezembro de 1989 no

Museu de Arte de São Paulo (MASP)

ReferênCIA ARQUIVO HISTÓRICO DO MASP

Caixa 4 / Pasta 24

Peças inscritas pelas próprias empresas e

designers. Na maioria, representadas por fotos e desenhos.

DIRETOR DA INSTITU

Tema da exposição (palaVra-chaVe)

Produto brasileiro, indústria, design

Curadores ou responsávels pelO

PROJETO DA EXPOSIÇÃO

P. M.Bardi, Lina Bo, promovida pelo

Departamento de Tecnologia da Federação

e Centro das Indústrias do Estado de São

Paulo (FIESP/CIESP) e Instituto Nacional de

Propriedade Nacional (INPI)

OBjetivo do EVENTO

A mostra proposta pelo Departamento

de Tecnologia da FIESP/CIESP, com apoio

do INPI, fez parte das comemorações do

centenário de nascimento do empresário

Roberto Simonsen. O objetivo da

exposição foi promover a importância

do desenvolvimento e aprimoramento da

tecnologia do país e o papel do "design"

como um componente fundamental do

processo tecnológico. 


\section{Alvar Aalto - arquiteto e}

DESIGNER FINLANDÊS I898 - 1976

TítULO DA EXPOSIÇÃo

DATA E LOCAL

De 8 de agosto a 3 de setembro de 1989,

no Museu de Arte de São Paulo (MASP)

REFERÊNCIA ARQUIVO HISTÓRICO DO MASP

Caixa 7 /Pasta 32

DiRETOR DA INSTITUIÇÃO NO PERÍODO

Pietro Maria Bardi

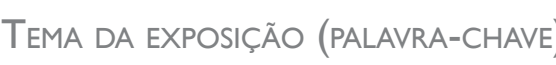

Alvar Aalto, arquitetura moderna, design

CurAdores ou responsávels pelo

PROJETO DA EXPOSIÇÃO

P. M.Bardi, Lina Bo, Elissa Aalto, Embaixada

da Finlândia e Associação Brasileira de

Escritórios de Arquiteturas e o grupo

AEDICANDUM

OBjeTIVO DO EVENTO

Numa ampla retrospectiva da obra do

arquiteto e designer finlandês, o catálogo

da mostra, bem como a exposição,

dedicam-se a apresentar o currículo de

Aalto, breves parágrafos dedicados aos

projetos arquitetônicos, trechos de textos

ou depoimentos proferidos e a relação de

mobiliário e objetos criados pelo arquiteto.

MATERIAL EXPOSITIVO

Fotos, textos, documentos e plantas dos

projetos arquitetônicos, objetos e mobiliário desenvolvido pelo arquiteto.

FORTUNA CRÍTICA

A força dos clássicos nos conceitos de Aalto.

O Estado de S. Paulo, 8 de agosto de 1989. 
